Zsuzsanna Szerényi - Géza Salamin - Zsófia Nemes (eds.)

\title{
ENVIRONMENTAL, SOCIAL AND ECONOMIC SUSTAINABILITY IN THE LIGHT OF THE GEOPOLITICAL CHALLENGES OF OUR AGE
}

Corvinus University of Budapest

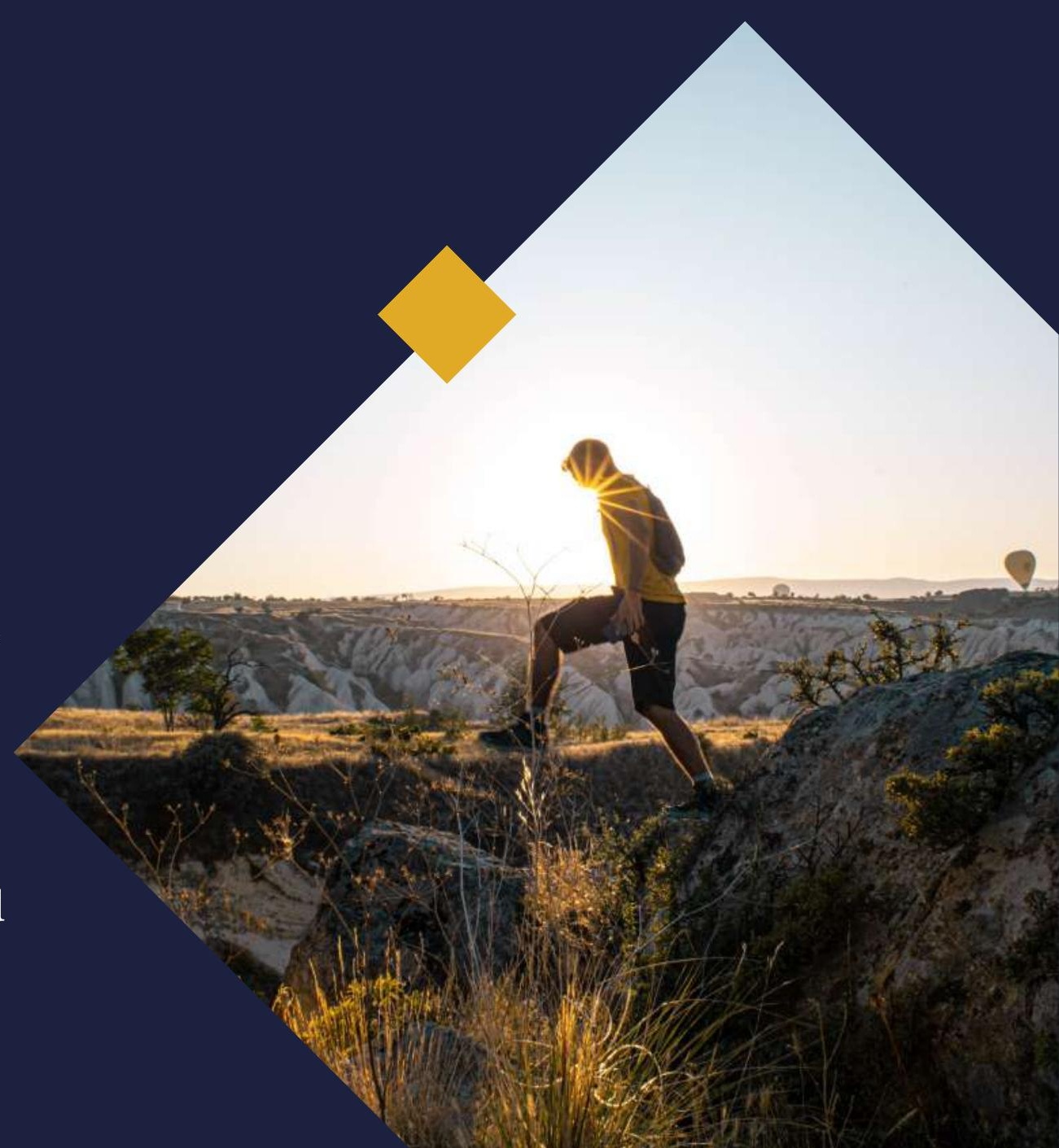




\section{ENVIRONMENTAL, SOCIAL AND ECONOMIC SUSTAINABILITY IN THE LIGHT OF THE GEOPOLITICAL CHALLENGES OF OUR AGE}

Papers of early career researchers and PhD students from the Doctoral School of International Relations and Political Science 


\section{Corvinus Geographia, Geopolitica,} Geooeconomia

Book series of Department of Geography, Geoeconomy and Sustainable Development

Series editors: Géza Salamin - Márton Péti - László Jeney 
Zsuzsanna Szerényi - Géza Salamin - Zsófia Nemes (eds.)

\section{ENVIRONMENTAL, SOCIAL AND}

ECONOMIC SUSTAINABILITY IN THE LIGHT OF THE GEOPOLITICAL CHALLENGES OF OUR AGE

Papers of early career researchers and $\mathrm{PhD}$ students from the Doctoral School of International Relations and Political Science

Corvinus University of Budapest

Budapest, 2021 


\section{Editors:}

Zsuzsanna SZERÉNYI

Géza SALAMIN

Zsófia NEMES

The articles have been pre-selected by:

Zoltán BALÁZS - Péter MARTON - Sándor Gyula

NAGY - Zsuzsanna SZERÉNYI -Réka VÁRNAGY

\section{Scientific review:}

György FOLK - Zoltán KELEMEN - Ákos KENGYEL -

Sándor KEREKES - János Balázs KOCSIS - Tamás

KOCSIS - Attila KOROMPAI - Bernadett LEHOCZKI

- Pál LUKÁCS - Márton PÉTI - Miklós ROSTA -

Kinga SZÁLKAI - Borbála TAKÁCSNÉ TÓTH - Gábor VÍGVÁRI

English language proofreading:

Nicholas JOHNSON - Attila KLEIN - Philip SAXON Robert THIESSEN

ISSN 2560-1784

ISBN 978-963-503-886-2 (e-book)

DOI 10.14267/978-963-503-886-2

The volume was supported by the Pallas Athene Domus Meriti Foundation (PADME).

\section{\& corvinus UNIVERSITY \\ of BUDAPEST \\ CORVINUS DOCTORAL SCHOOLS}

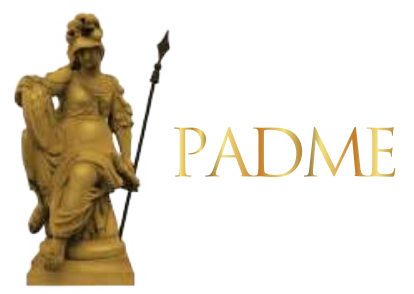

(C) Corvinus University of Budapest - Doctoral School of International Relations and Political Science

Publisher: Corvinus University of Budapest

Cover design: Virág VARGA

Cover Photo by Oziel Gómez from Pexels 


\section{TABLE OF CONTENTS}

Geopolitical dimensions of the sustainability challenge: Introduction

CHAPTER I

Social inequalities and sustainability

Bottom-Up Protests in Morocco, Tunisia, and Algeria: A Struggle Against "Inherited" Sociospatial Inequalities

Hamid AIT EL CAID

Measuring inequalities in access to water and sanitation: A literature review of the quantitative studies published in 2015-2020

Urangoo BULGAMAA

The multidimensional poverty measurement in Latin America: A short introduction

Ágnes DEÁK

Gender Equality as a sustainable development goal in the Maghreb? Morocco, Tunisia and

Algeria compared

Xénia Zsuzsanna SIPOS.

\section{CHAPTER II}

Sustainability in political thought.

The role of techno-optimism in environmental sustainability narratives

Lilla Sarolta BÁNKUTY-BALOGH

Can the trilemma of environmental policy be solved?

Izabella FEIERABEND

Bös-Nagymaros, the Political Taboo of Hydroenergy

Gábor László PORHAJAS - Bence Álmos KISS

Expanding ecological rights and the effective dimension of political rhetoric

Csendike SOMOGYVÁRI

\section{CHAPTER III}

International relations in the light of sustainability.

Indonesia's Foreign Policy in Energy Security Issues

Donie KADEWANDANA

Labeling of statuses and its effects on human rights of the Rohingya people in Bangladesh:

Rhetoric and Reality

Sodip ROY

Can international organisations save the environment? - The response of the Council of Europe to the global environment crisis

Adrienn TÓTH-FERENCI

CHAPTER IV

Analysing sustainability issues in regional/national economic dimension

The promise of sustainability and the pandemic? How Hungarian fashion production companies could gain better position in the global supply chain due to relocation tendencies

Emese DOBOS-NAGY...

Social sustainability as a synonym for social flexibility in the international context - The case study of Ireland

Katalin NÁDAS-NAGY

Analysis of the youth labor market in the EEU countries

Bauyrzhan URAZYMBETOV 


\section{Geopolitical dimensions of the sustainability challenge: Introduction}

The need for international responses to global environmental challenges has been obvious since this topic emerged. The first important, globally acknowledged steps towards revealing the sustainability threat of the Earth began with the launch of Man and Biosphere programme of UNESCO in 1970, then the first world environmental protection congress of the United Nations in Stockholm (1972), and the activity of the Club of Rome, which made it clear for the entire global arena that environmental challenges do not respect borders and states. The most influential (also most debated) output of the latter was the report titled 'The Limit to Growth' in 1972, by MEADOWS and his fellows, which alarmed the wider audience for quick joint international actions at global level. Looking at the several multilateral - and often typically with global ambitions - agreements on issues related environmental themes, we can say that sustainability has become an elementary issue of international relations. However, its relation to geopolitics - which is in a sort of renaissance period - is less visible and described yet.

The global challenge of the Earth's sustainability would need a global governance. Angus FORBES (2019) in his popular movement argued for a global planet authority to save the biosphere, and claimed that the globalised citizens connected with each other via internet could voluntarily elect such a global government in a direct way. However, as even the UN has limited possibilities, it could achieve only setting up goals (see the 17 Sustainable Development Goals of 2015), generate negotiations and initte cooperation of states, but lacking real power, the responses to global challenges and the possibilities of global coordination depend and probably will depend on the governments of countries; countries which have specific cultural settings, political interests, physical and socio-economic resources depending on their specific territories and their own histories with their own geographies. The increase of importance of the geographic location of countries and their territory-specific resources are drawing the attention to the role of geopolitics. The emerging field of geopolitics - according to the classical definition - is the study of the effects of Earth's geography (human and physical) on politics and international relations (DEVETAK et al. 2017). Although the elements of the environmental system operate in a geographic logic, the spatial understanding of politics of sustainable development is less revealed yet. This volume intends to enlighten and reflect on that dimension too. 
Jean-Charles HOURCADE in his work of 2008 argued that certain alerts on global environmental challenges provided stakes of geopolitics of sustainable development. Between 1970 and 2001 he identified the emergence of four alerts on environmental challenges, which resulted in significant negotiations among countries, as well as some international multilateral agreements with geopolitical significance. On his list we can find the nuclear alert, the forest dieback alert (mainly in relation with acid rains), the ozone alert which is considered probably the most successful global solution so far; and the climate change alert. In his view, since 2001 the serious conflict is between the interest of the developed countries - which seem to be very active in greening production and consumption patterns - and the developing countries which request possibilities of economic growth and catching up. These conflicts can be detected in the North-South dichotomy of the world. Looking at the diverse position of countries regarding the importance of "green policies" (which can sometimes radically change over time within the same country) there is no doubt that tackling with the responsibilities of global environmental issues holds serious conflicts among various countries. The different interests can be rooted in their development paths, different cultures and in the specific economic (typically short term) interests of the countries.

Drawing a comprehensive understanding of the various possible aspects of the relationship between geopolitics and the global sustainability challenge obviously cannot be the ambition of such a short introduction. However, it is worth mentioning some key challenging processes of our age, which could be understood more deeply by applying geopolitical approach in some key issues.

In our age we are experiencing a strengthening competition for environmental resources, which are typically specific to certain geographic areas. The increasing scarcity of agricultural products, food and water, the restructuring demand energy sources - both traditional and green energies -, the green environment and many other geography-specific conditions and their changes due to climate change can more and more frequently result in inter- and intragovernmental tensions, and lead to migration pressure (RAKONCZAI 2021).

The other geopolitically relevant key issue of sustainable development is the increasing inequality and spatial concentration. In 2019,500 biggest companies $^{1}$ produced $37,8 \%$ of the world's GDP, but they employed only 70 million people. The pure market processes failed to balance the huge differences between regions, and this inequality can be experienced in various social dimensions too, while the general Western world solutions for capitalism and liberalism

\footnotetext{
${ }^{1}$ Available at: http://fortune.com/global500/list/ (Accessed on 15 Jan 2021)
} 
seem to be inadequate in the Global South and also in the Eastern countries, resulting in serious lack of common global understanding. While the dominant states try to make accepted the Western norms of liberal democracy and value system, other societies with different traditions and values request respect for their own culture. The geographically diverse demographic trends are probably the most crucial issues for the future of the Earth, bringing serious geopolitical tensions. While from the beginning of the $18^{\text {th }}$ century it took 124 years for the Earth's population to grow by 1 billion, since 1975, the world's population has grown by that every 12 years on average. ${ }^{2}$ The demographic change has completely different patterns in different parts of the world, and through the migration pressure it brings serious issues to the countries of origin - e.g. the brain drain loss - and the target countries too, see for example integration problems and cultural tensions.

These processes challenging the sustainable development have obviously clear geopolitical dimensions, and their understanding needs further explorations in the academic world. This volume representing contributions of early career researchers is just one small step towards understanding more geopolitical aspects of sustainable development. This volume is one of the results of the rising story of the Doctoral School of International Relations and Political Science in a strong collaboration with the Institute of International, Political and Regional Studies. The Doctoral School launched a new PhD programme in 2017 focusing on geopolitical research, which was complemented by the issue of sustainable development. This topic could attract and motivate the $\mathrm{PhD}$ students of the Doctoral School to find connections between their own research field and sustainable development.

The present volume contains 14 articles written by the $\mathrm{PhD}$ students of the Doctoral School of International Relations and Political Science, coming from six different countries from Bangladesh to Morocco etc. There are 4 thematic chapters in the book (Social inequalities and sustainability; Sustainability in political thought; Analysing sustainability issues in regional/national economic dimension; International relations in the light of sustainability), each consisting of 3-4 articles which have many potential interconnections, and might draw the attention of the readers to some new research fields and aspects of the extremely complex concept of sustainability.

Géza Salamin

Head of Institute of International, Political and Regional Studies of CUB

\footnotetext{
${ }^{2}$ Our World in Data 2021, Available at: https://ourworldindata.org/world-population-growth (Accessed on 15 Jan 2021)
} 


\section{References}

DEVETAK, R. - GEORGE, J. - PERCY, S. (eds.) 2017: An Introduction to International Relations (3rd ed.). Cambridge: Cambridge University Press.

FORBES, A. 2019: Global Planet Authority: How We're About to Save the Biosphere. LID Publishing.

HOURCADE, J. C. 2008: The Geopolitical Stakes of Sustainable Development. In: ÉTUDES Volume 408, Issue 2, 2008, pp. 175-186.

MEADOWS, D. H. - MEADOWS, D. L. - RANDERS, J. - BEHRENS III, W. W. 1972: The Limits to Growth. A Report for the Club of Rome's Project on the Predicament of Mankind. New York: Universe Books.

MEADOWS, D. L. - BEHRENS, W. W., III - MEADOWS, D. H. - NAILL, R. F. RANDERS, J. - ZAHN, E. K. O. (eds.) 1974: Dynamics of growth in a finite world. Cambridge, Massachusetts: Wright Allen Press.

RAKONCZAI, J. 2018: Global and Geopolitical Environmental Challenges. Corvinus Geographia, Geopolitica, Geoeconomia. Corvinus University of Budapest, Budapest. 
Chapter I

Social inequalities and sustainability 


\title{
Bottom-Up Protests in Morocco, Tunisia, and Algeria: A Struggle Against "Inherited" Socio-spatial Inequalities Hamid AIT EL CAID ${ }^{3}$
}

\begin{abstract}
In the last five years, Tunisia, Algeria, and Morocco experienced a new wave of protests from the most under-developed or often "marginalised" regions within each country. "Thirsty" protests in Morocco's Zagora region in 2017, unemployment protests in Tunisia's Tataouine region since 2017, and anti-marginalization protests in Algeria's Tin-Zaouatine region in 2020 are all examples of bottom-up activism against continued socio-spatial inequalities in the Maghreb. This paper aims to examine the role of popular protests in reducing regional disparities in Morocco, Tunisia, and Algeria, which could be described as "inherited" or "sustained" social patterns. To meet this aim, cross-case analysis will be carried out. Results of the comparative study reveal that bottom-up protests played different roles in each case, where in Morocco's Zagora region, protesters "drove" the government to act, while in Tunisia and Algeria, protesters' role was-and-remains "ineffective" in meeting their demands as demonstrations continue in Tunisia and Algeria.
\end{abstract}

Keywords: Morocco, Tunisia, Algeria, Protests, Socio-spatial Inequalities

\section{Introduction}

On December $17^{\text {th }}, 2010$, Mohamed Bouazizi, a Tunisian street vendor, set himself on fire in protest after police confiscated his merchandise. This action marked the beginning of what was to be known as the "Arab Spring" that caused deep socio-political transformations in the Middle East and North Africa consequences of which can still be witnessed today. Microlevel research was carried out using mainstream literature and analytical studies on the "Arab Spring" The majority of publications examined socio-political, and often economic implications of the "Arab Spring" from both national and cross-national levels. Yet little research was conducted on the micro-level aspect of the revolutions in which the most "marginalised", "isolated" and "under-developed" regions can be treated as roots of such developments and thus drivers of the wider socio-political changes.

Bouazizi's hometown "Sidi Bouzid" lies in central Tunisia and was regarded as the less "developed" district of the country by several indices. In 2010, the Sidi Bouzid region topped the ranking in the poverty index (32\%) and unemployment among tertiary degree holders (41 $\%)^{4}$. These figures did not change much after the revolution due to statistics from the same sources in 2015 displayed that Sidi Bouzid and its neighbouring regions in Central and Southern Tunisia did not improve in terms of poverty (the figure remained at 33\%) and unemployment among tertiary degree holders (even increased to 57\%). This unfavourable

\footnotetext{
${ }^{3}$ Corvinus University of Budapest, Doctoral School of International Relations and Political Science, PhD student, hamid.ait-el-caid@stud.uni-corvinus.hu

${ }^{4}$ Data compiled by Tunisian "National Institute for census", Ministry of Social affairs, UNICEF, Ministry of planning and regional development and Ministry of development, investment and international cooperation.
} 
situation triggered further protests in 2017 in "Tataouine", the largest region, which is oil-rich, yet the least developed part of the country.

Popular protests in Tataouine led to the formation of The Kamour Movement, which demanded employment opportunities, regional development as well as equal distribution of oil and gas revenues drilled in the region. Under these circumstances, we may therefore conclude that there is a huge gap between regions regarding human and socio-development in Tunisia, which can be called "socio-spatial inequality", manifested by disparities in wealth distribution, state budget funding and the availability of a better standard of living such as drinkable water, electricity, a sewerage treatment system, etc.

I deliberately started with the case of Tunisia other than the other Maghreb countries Algeria and Morocco - in order to illustrate that the cradle of the "Arab Spring" and its consequences were brought about by a desperate man from an underdeveloped region, which allows us to highlight the importance of micro-level or in-country studies in the understanding of macro-level changes. Algeria and Morocco are no different from Tunisia with regard to regional inequality in terms of social development. The wealthiest and most developed regions can also be found in Northern and Coastal areas of the two Maghreb countries, whereas in Central and Southern regions there was little development, which then led the ignited citizens of these regions to protest.

As selected case studies for this paper, three protest movements were chosen to describe the situation in the Maghreb countries. The Kamour Movement protest in Tunsia's Tataouine region (2017- up to 2021), the “Thirsty” protests in Morocco's region of Zagora (2017) and anti-oppression protests (2020) in Algeria's Tin-Zaouatine region. The three case studies share a lot of common features allowing us to make sense of the existence of "socio spatial" inequalities and explore the role of popular protests in the struggle against injustices and inequalities across regions.

A quick look at the recent history of the three Maghreb countries reveals that the struggle against colonial powers, namely France and Spain, was undertaken by people from all regions as independence was the sole objective of every person. After decolonization, Morocco, Algeria, and Tunisia became sovereign states in the mid-twentieth century and began building national institutions. However, power and decision-making were centred in Northern and coastal regions, where the capital cities of Rabat, Algiers, and Tunis are located. Since independence, centralization of power has brought other regions, especially Central and Southern regions, into marginalization and exclusion in terms of socio-economic development, political decision- making as well as gaining their share of state budgets. 
MEDDEB (2020) emphasised that it was in Tunisia's interior regions where the main outbreaks of the revolution had taken place. He argued that former governments had insisted on biasing the interests of the more privileged coastal regions, while ignoring inland and border areas since the country gained independence in 1956. Morocco on the other hand embarked on socio-spatial inequalities during a "protectorate" era as French colonial powers classified the country into two parts: the "profitable" and "non- profitable Morocco". The "Profitable" regions were lush and plain areas where major economic and political activities were managed (such as Casablanca, Rabat, Marrakech, and Fes), while the rest of the country (mainly mountainous and desert areas) was considered as The "non-profitable", supplying only raw materials and minerals. According to RACHID (2020), the "sad" reality is that the colonial policy persisted even in post-1956 Morocco, which made the mountainous and southern regions suffer from the division though these areas were rich in minerals, such as gold, silver, and copper. Similarly, in Algeria, Hadji (2018) it was affirmed that the regional disparities still exist after more than half a century since independence and may have even widened because of a failure to create the desired regional balance.

The concept of "sustainable development" could have an opposite meaning in the Maghreb context as the persistence of "inherited" inequalities among regions. This would let us relate sustainability to regional inequality, thus we may be talking about sustainable underdevelopment" rather than "development". In this paper, I am shedding light on why the other way around for sustainability can be applied to the Maghreb region as long as power centralisation, unequal wealth distribution and disparities in the level of human development continue. In light of the adverse fact over sustainability of socio-spatial inequalities, popular protests emerge as a potential game changer of the status quo. Therefore, the three cases of protests in the Maghreb countries will allow us to see how far bottom-up activism can alter the opposite significance of "sustainability" into its natural meaning.

\section{Socio spatial inequalities: why does it matter in Morocco, Algeria, and Tunisia?}

\subsection{Conceptualizing socio-spatial inequality}

When looking at the term "socio-spatial inequalities", we can draw our understanding according to two contesting schools of thought: 1) neoclassical, and 2) dependency, neoMarxism schools. (WEI 2015, p. 1). As early as 1920s, socio-spatial inequality was referred to as regional inequality by the neo-classical approach, which is dominated by theories of economics, suggesting that regional inequality happens when there is a "disequilibrium" 
between supply and demand in more developed regions. (WEI 2015, p. 2). In contrast, BORTS - STIEN (1964) explained that regional equalities take place when "labour tends to move to more developed regions with higher wages, whereas capital tends to move to labour-intensive and more profitable sectors in less developed regions". This pattern therefore equalizes wages and the cost of capital and reduces regional income disparities.

On the other hand, the Neo-Marxism and Dependency schools, as illustrated by EMMANUEL (1972) and FRANK (1967), assert that regional inequalities occur when capital "spreads to the periphery and creates a dependent core-peripheral structure, which in return sustains labour outflow and unequal transfer, exacerbates the stagnation of the periphery" (WEI 2015 , p. 2). This trend to regional inequality brought to light capitalism as an environment where gaps in wages, market and capital are inevitable and a pre-condition for a capitalist society to occur. However, those definitions are perceived to examine regional inequalities with a short distance between what a more or a less developed region seem to be. In other words, space was understood from urban-suburban dichotomy, without referring to the broader sense of what a "region" stands for.

It is worth pointing out the fact that social inequalities across regions also attracted researchers in geography. Traditional social science literature on regional inequality puts emphasis on socio-economic gaps among individuals and ignores "spatial" factors. For example, Alexander von Humboldt (1769 - 1859) was one of the contemporary geographers to study human interaction with "spatial differences" (HADJI 2018, p. 119). Later, space and development became a popular axis in geography across the world, including in MENA regions. Nevertheless, social science scholars of justice and equality paid little attention to regional disparities. John RAWLS (1971), who set the principles of justice, made no indication to "space" in a theory of Justice. Therefore, geographers' expertise in space differences, manifested by adverse binaries (e.g., desert area vs lush area, mountainous area vs plain area, coastal vs in-land), made them complement what social scientists were missing in defining and theorising crucial concepts such as justice and equality.

\section{2. "The Maghreb": an example of existing socio-spatial inequalities.}

The socio-economic gap between regions is evident in the three Maghreb countries: Morocco, Algeria, and Tunisia. These countries share the same regional composition both in terms of geography and social disparities. Northern regions monopolise political and economic powers which in turn affect the social level of citizens residing in those regions, whereas central and Southern regions, are mostly barren, mountainous, and desert lands covering almost 70\% 
of the total national territory. Thus, regardless of the little population density of the central and southern regions, due to harsh climate conditions (too cold in mountainous areas, and too hot in desert areas), the socio-economic development still lags behind compared to the rest of the regions, in plain, lush lands, and near the coasts.

The most efficient way to discover socio-spatial inequalities is by measuring the level of poverty by region. For this purpose, there are government agencies which provide statistics in Tunisia (National Institute of Statistics), Morocco (High Commissioner for Planning) and Algeria (National Office for Statistics), and monitor and compile data on poverty from regional and micro-regional levels. But, when searching for data or a poverty map in web-based search engines, no data appears on this topic, except for archived maps from 1999 to 2006, and which were found in research papers conducted by university researchers. The government allegedly refuses to talk about the existence of poverty maps, even if levels of poverty are increasing in the central areas, especially in border regions (Eastern, Western and Southern regions).

According to the poverty map of Tunisia (Figure 1), we can detect that the Southern, South-western, and Middle western regions account for nearly $78 \%$ of the country's total poverty rate.

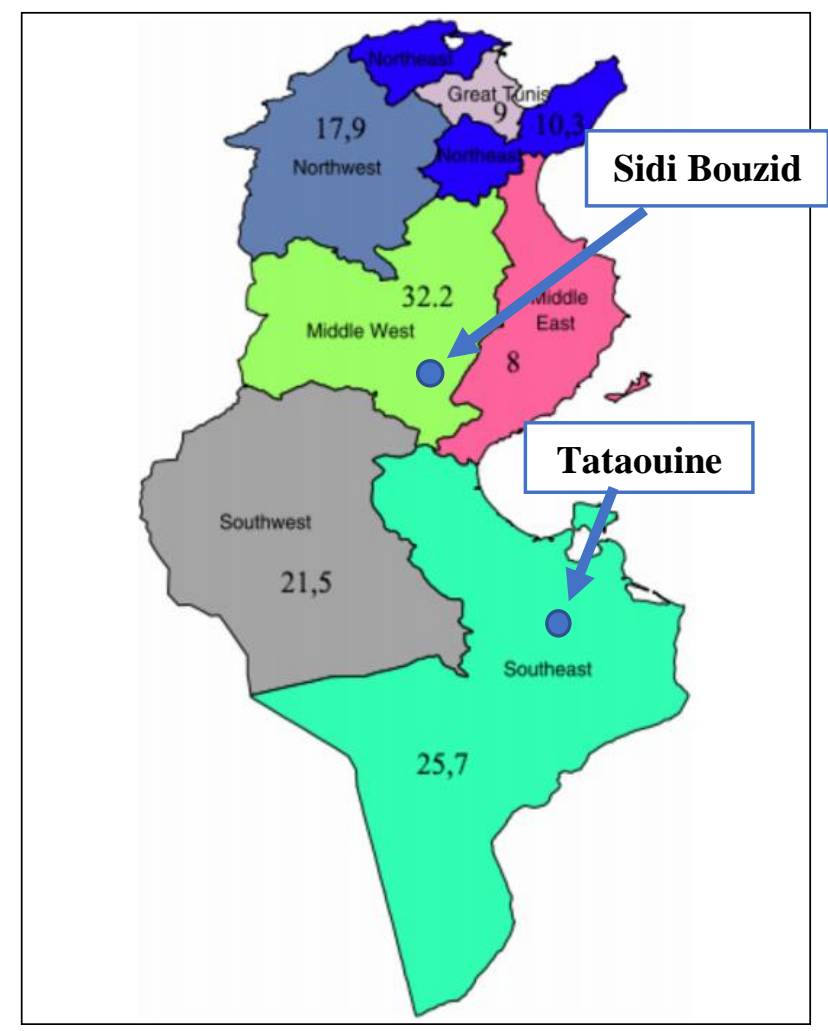

Figure 1: Poverty rate (\%) in Tunisia by regions in 2010.

Source: National Institute of Statistics in Tunisia 2010 
Moreover, those regions are mostly desert and semi-arid lands, but rich in oil and gas reserves. For example, the South-eastern region, which borders with Libya, is ranked as the second "poorest" region with $25 \%$ poverty rate.

The town of Titaouine, the birthplace of the Kamour Movement in 2017, is situated in the middle of the region which explicitly exhibits the struggle of its citizens for local socioeconomic development. Similarly, the town of Sidi Bouzid, which is situated in Middle Western Tunisia, as illustrated in Figure 1, was ranked as "the poorest" of the country's regions with $32.2 \%$. This unfavourable social condition is what drove Mohamed Bouazizi to set himself on fire, which later prompted nationwide protests and escalated into what was then known as The Arab Spring sweeping other countries in the Middle East and North Africa.

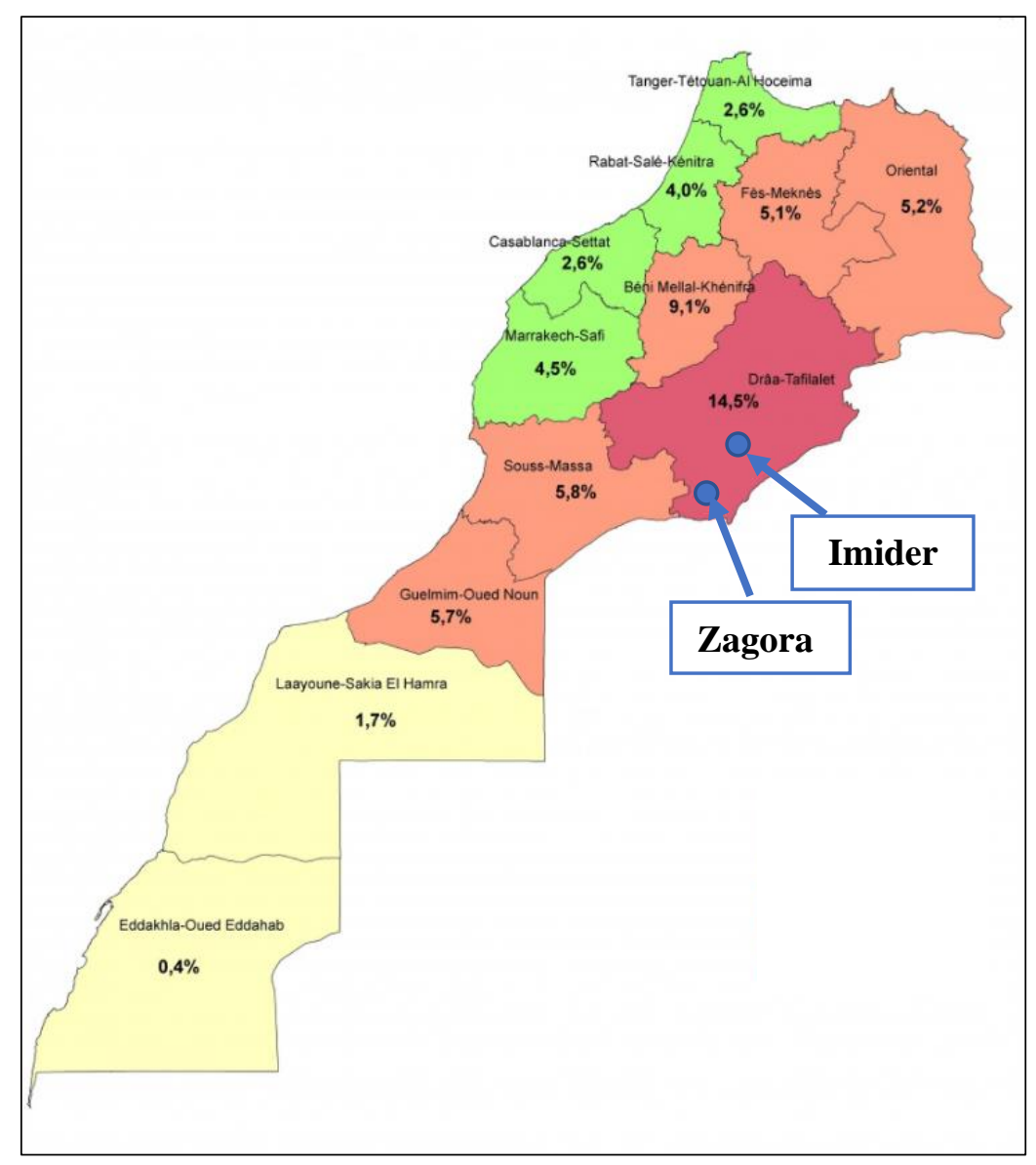

Figure 2: Monetary poverty rate (\%) in Morocco by administrative regions in 2014. Source: High Commissioner for Planning of Morocco 2014.

The popular protests, that swept Morocco in 2011 as part of The Arab Spring Revolutions, pushed the state to introduce new administrative regions in an attempt to promote decentralization and give the new regions autonomous governance. However, rationale for forming the new regions received criticism of further regional disparities as the already 
developed regions merged, while certain under-developed provinces (sub-regions) got integrated into each other in one region. This is clearly the case with the Draa-Tafilalet region, as it topped the "monetary poverty" rate by 14,5\% in 2014 (see Figure 2). The Draa-Tafilalet region is situated in South-Eastern Morocco. The region sits at the foot of the High and Middle Atlas Mountains and covers large barren lands as part of the Sahara Desert. Its inhabitants depend on tourism and agriculture as the main economic activities, but those activities are subject to frequent crises due to desertification and unpredicted circumstances affecting tourist arrivals in Morocco, such as the Covid-19 pandemic.

The "Thirsty" revolution took place in 2017 in the Zagora province of the Draa Tafilalet region, where residents protested against the shortage of water. Besides, local citizens of the village of Imider (see Figure 2) have since 1986, protested against unemployment and the State's exploitation of a silver mine near the village. Both cases from the Draa-Region of Morocco demonstrate the persistence of colonial policy dividing the country into two territories: "profitable" and "non-profitable".

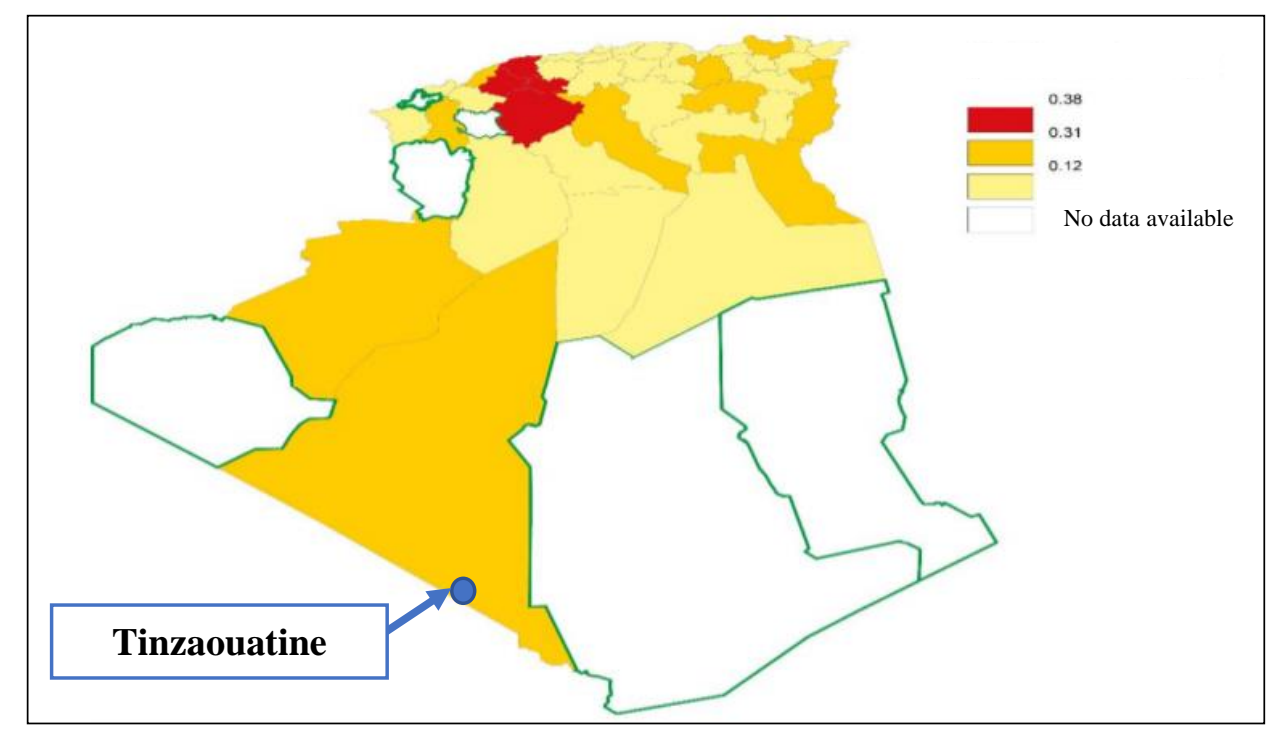

Figure 3: Poverty index per family (from 0 to 1 ) in Algeria by regions in 2005, Source: Data based on the National Investigation on livelihood and poverty in Algeria.

The situation with socio-spatial inequalities in Algeria is no different from that of Morocco and Tunisia. Despite the lack of up-to-date data on poverty across the regions in Algeria, the 2020 protests in Tinzaouatine at the Malian border (see Figure 3) demonstrate that there is a huge gap between the northern and southern regions in terms of human development and access to social benefits. Figure 3 shows the village of Tinzaouatine in the Southern Wilaya (district) of Adrar and where the "poorest families" live by 0.31 together with neighbouring 
Wilayas in the south and by the borders. The region marked in "red" is an extension of the Atlas Mountains in Algeria which includes 4 Wilayas: Tiaret, Ghelizan, Tissmesilt, and Chlef. However, regions in white indicate an absence of data.

\section{3. "Sustainability" and the other way around: how socio-spatial inequalities remain unchanged?}

In the United Nations glossary, we find that sustainability is always connected to the 17 global development goals aimed at making the world a better place by 2030. Among these 17 goals is "reduced inequality" within and among countries. Though the UN definition of "inequality" relies on "income gap", it implicitly includes the regional or spatial "inequality". Nevertheless, as soon as the year 2030 approaches, there will not be much change concerning inequality as long as capitalism insists on it, and crises deepen it. For instance, several analyses and studies suggest that the Covid-19 pandemic crisis has affected middle-class people prompting therefore an increase in poverty and maintenance of wealth by the upper-class elites. Past pandemics proved a significant relationship between crises and inequalities. (FURCERI et al. 2020). This reality drove us to reconsider the concept of sustainability from its positive attribution to development to the opposite direction, which would lead us to propose a new concept of "sustainable under-development" considering the evidenced reality.

The Maghreb context with socio-spatial inequalities is a significant example of the opposite semantics of the term "sustainability" where certain regions have remained more privileged than others for over 60 years since the independence of the Maghreb states. However, there may be a period when "sustainable socio-spatial inequalities" will be reversed into the United Nations seeking "socio-spatial equalities" if changes occur at the levels of political systems, public policies, or governance.

In some democratic regimes, the fight against inequalities may take participatory paradigms. Citizens have opportunities to raise their voices through different channels of participatory governance allowing them to directly express their exclusion or marginalization to the policy and decision makers. But, in the non-democratic context, such practices may exist, but they do not help make a real-world impact. In the context of Morocco, Tunisia and Algeria, citizens from the less-developed regions within each country went out onto the streets to protest for their basic social rights, such as employment and access to public services.

To understand the role that popular protests could play in the struggle against sociospatial inequalities, I studied one protest movement from each Maghreb state. These were the “Thirsty” protests in Morocco's Zagora region in 2017, anti-marginalization protests in Tin- 
Zaouatine of Algeria in 2020 and the "Kamour" Movement in Tunisia since 2017. The study involves quantitative and qualitative data of the main characteristics of each protest movement/activity, and its aftermath public and political reactions.

\section{a. Protests in Zagora (Morocco), $24^{\text {th }}$ September $-8^{\text {th }}$ October 2017}

- Number of participants (approximately): 200-300 persons per each demonstration. ${ }^{5}$

- Protest substance: shortage of water, solidarity with detainee protesters.

- Main slogans (personal translation from Arabic to English): "there is no health care, no education in Zagora "66 "oh Zagora citizen, it's time to speak up for your rights!"7

- Forms of protests and tools for communication: Spontaneous gathering, Sit-ins, Marches, Holding empty bottles of water.

$>$ Public and political reaction: 21 protesters arrested, most of whom were minors. Government formed a special committee to drill for water in the region. Minister of water Charafat Afailal visited Zagora and pledged to solve the water crisis. Construction of a new mega well completed in 2019.

\section{b.Protests in Tin-Zaouatine (Algeria), $15^{\text {th }}-17^{\text {th }}$ June 2020}

- Number of participants (approximately): 40-100 people. ${ }^{8}$

- Protest substance: Authorities built a fence on the border preventing the town's citizens from having access to the river, solidarity with a protester allegedly died after being shot by Army forces.

- Main slogans (personal translation from Arabic to English): "What a shame! The fence plus bullets", "oh The Wali (district governor) leave office now !"9

- Forms of protests and tools for communication: Spontaneous gatherings, Marches, Demonstrations, sit-ins.

$>$ Public and policy reaction: Ministry of defence denied accusation of shooting the protester. Ministry of defence conducted investigation on the death of the protester.

\section{c. Protests in Tataouine (Tunisia), 23rd April 2017 - continues up to 2021:}

- Number of participants (approximately): 500-1000 participants in the early days of the protest movement.

\footnotetext{
${ }^{5}$ Based on my estimation in the video footage: https://www.youtube.com/watch? $\mathrm{v}=\mathrm{PnkPt} 1 \mathrm{SCQ} 80 \& \mathrm{t}=250 \mathrm{~s}$

${ }^{6}$ Video footage: https://www.youtube.com/watch?v=PnkPt1SCQ80\&t=250s

${ }^{7}$ Video footage: https://www.youtube.com/watch?v=qSqdphP-v5M

${ }^{8}$ Based on my estimation in the footage: https://www.youtube.com/watch?v=z0j_lvrmDRk

${ }^{9}$ Video footage: https://www.youtube.com/watch?v=5ALKJpkoLtQ
} 
- Protest substance: Employment in oil and gas companies.

- Main slogans (personal translation from Arabic to English): Chanting revolutionary poems and phrases such as "by our soul and blood, Tataouine will prevail!" 10

- Forms of protests and tools for communication: Use of social media (official Facebook page $^{11}$ ) Sit in in tents around Kamour oil facility, demonstrations.

$>$ Public and policy reaction: Agreement between the movement and government ends the sit in, which promised to recruit 4500 persons from the region, arrest of the movement's spokesperson in 2018., another agreement signed in 2020 to execute the provisions of the previous agreement.

\section{Conclusion}

Analysis of the three protest movements in the Maghreb countries reveals different roles in the struggle against "inherited" inequalities. A thorough observation of the quantitative indicators of the protests including its temporal-spatial span shows that popular protests influenced policy and decision makers in different ways.

In Morocco, the government's reaction was responsive and attempted to quickly absorb further civil unrest thus avoiding escalation into nationwide protests. Two weeks after the last demonstration in Zagora, Water minister Charafat Afailal visited the region and set up a plan to supply the citizens with non-stop potable water. After almost a year of negotiations with multiple stakeholders, a water drilling well was constructed which eventually supplied drinkable water to the majority neighbourhoods of the city, although some quarters on the outskirts still lack a water supply due to the absence of legal housing licenses or perhaps because of the reluctance by local authorities. ${ }^{12}$

The situation with the Tin-Zaouatine protests in Algeria is not much different from that of Zagora in Morocco since both events were driven by a shortage of water. However, Algerian's government failed to some extent to accommodate the protest demands and simply denied its responsibility in the revolt. This explains how other towns in the Southern regions saw marches in solidarity with Tin-Zaouatine. The reason for the state's ignorance of the TinZaouatine protesters' demands, according to researchers and opposition politicians, lies in the unilateral security approach which the state adopts over communities living along the borders with Mali, Niger, and Libya, as part of efforts to halt smugglers and terrorist groups from

\footnotetext{
${ }^{10}$ Video footage: https://www.youtube.com/watch?v=oFHVyNzKyEw

${ }^{11}$ The "Kamour" movement official Facebook page: https://www.facebook.com/elkamour/?ref=page internal

12 Personal observation of the situation in the town.
} 
crossing the borders. Besides, Tin-Zaouatine is the most underdeveloped of all the other towns in the Sahara and Sahel region, and perhaps in the world, asserted Hussain HOWAM (2020). It should be noted that the Tin-Zaouatin protests happen under on-going political transition following mass demonstrations across the country since 2019.

The "Kamour Movement" in Tunisia's Tataouine region distinguishes itself from the other popular protests in Algeria and Morocco in several aspects. First, the movement has since its foundation in 2017 continued sit-ins around the Kamour oil facility demanding the government to implement its promises for employment. Moreover, the legacy of the Tunisian revolution during the Arab Spring in 2011 is utilized in the movement to advocate for the protesters' rights. The use of revolutionist poems and social media as a tool of communication between its members shows how well institutionalised the movement is compared to other protest movements in the less developed regions in Morocco and Algeria. Another particular feature of the movement is that coordination of activities across the Tataouine region is managed by ten protest leaders, allowing a balanced leadership structure rather than a "hierarchal" one which would facilitate repression by the authorities" (MEDDEB 2021).

Upon analysis of the different popular protests from the less developed regions in Maghreb countries, we can find that popular protests in the Zagora region of Morocco demonstrated a sufficient degree of "actorness" which pushed the government to react and seek solutions for basic issues affecting the region. In Algeria's Tin-Zaoautine case, protests were met with the State's "defensive" discourses and promises for inclusion amid political transition and constant mood for nationwide uprising. Whereas the Kamour Movement in Tunisia succeeded in bringing the government into negotiations but ended up with no concrete results, allowing protesters to continue their sit- ins around the oil facility.

As a conclusion, bottom-up protests in the Maghreb can address socio-spatial inequalities by "triggering" central governments about the regional disparities, but absence of inclusive policy approaches manifested by high levels of corruption and persistence of capitalism would further widens the gap between regions and turns "sustainable" development into "underdevelopment". Indeed, history is full of examples of resistance against the monopoly of power, resources, repression imposed by oligarchs, but fulfilling just and equal societies is not a matter of nation states alone, but rather a challenge for the global community at large, especially when the dichotomy of "developed countries" and "third world countries" remained a factual narrative. Human sacrifice through consolidated collective activism can thus break down the existing "sustainable" socio-spatial inequalities towards much-desired sustainable equalities. 


\section{References}

AL ARABI AL JADID 2017: Trial of 21 detainees in connection with the "revolution of thirst" protests in Zagora, Morocco. Available at: https://www.alaraby.co.uk. Accessed on 28 February 2021.

AL JAZEERA 2017: An agreement in Tunisia ends Tataouine Sit-in. Available at: https://www.aljazeera.net/news/arabic/. Accessed on 28 February 2021.

AL OMQ AL MAGHRIBI 2017: Thirst crisis in Zagora: A chronology. Available at: https://www.youtube.com/watch?v=ydCA4LFQT90\&t=4s . Accessed on 26 February 2021.

AL QUDS AL ARABI 2020: Algeria: The killing of a young man in a town on the border with Mali sparks widespread controversy. Available at: https://www.alquds.co.uk/. Accessed on 28 February 2021.

ATTAC MAROC 2017: Interview with Imider protesters: Residents protest plunder of their wealth and pollution of their environment. Available at: https://attacmaroc.org/. Accessed on 28 February 2021.

BLIDI, S. 2020: Tin-Zaouatine protests move the still sands of Southern Algeria. Al Arab. Available at: https://alarab.co.uk/. Accessed on 28 February 2021.

BORTS, G. H. - STEIN, J. L. 1964: Economic growth in a free market. New York: Columbia University Press.

CHERIF, Y. 2017: The Kamour movement and civic protests in Tunisia. Washington DC.

Carnegie Endowment for International Peace. Available at: https://carnegieendowment.org/2017/08/08/kamour-movement-and-civic-protests-intunisia-pub-72774. Accessed on 28 February 2021.

DERBALI, M. 2020: The Kamour sit-in: A chronology. Nawaat. Available at: https://nawaat.org/2020/11/27/. Accessed on 01 March 2021.

EMMANUEL, A. 1972: Unequal exchange: A study of the imperialism of trade. Monthly Review Press.

FRANK, A. G. 1967: Capitalism and underdevelopment in Latin America. Vol. 16. NYU Press.

FURCERI, D. - LOUNGANI, P. - OSTRY, J. D. - PIZZUTO, P. 2020: COVID-19 will raise inequality if past pandemics are a guide. Vox EU column. Available at: https://voxeu.org/article/covid-19-will-raise-inequality-if-past-pandemics-are-guide Accessed on 20 February 2021. 
HADJI, F. 2018: Regionalism in Algeria, a Balanced Development Option. Majallat Al-Ulum Al Ijtimaia 15, 26: pp. 118-129.

HAUT-COMMISSARIAT AU PLAN DU ROYAUME DU MAROC (n.d.): Rencontre: Pauvreté, vulnérabilité et inégalité, Rabat, 17/05/2017 | Galerie | Available at: https://www.hcp.ma/Rencontre-Pauvrete-vulnerabilite-et-inegalite-Rabat-17-052017_r259.html . Accessed on 26 February 2021.

HOWAM, H. 2020: Expert on Sahel and Sahara speaking on the regions of Timuaouine and Tinzazaouatine. Speech audio recording. Hirak news via Youtube. Available at: https://www.youtube.com/watch?v=-pUiE7DAP_g . Accessed on 28 February 2021.

JAMAII, A. - ROUSSELIÈRE, D. - DANIEL, C. 2017: Semi-parametric Regression-based Decomposition Methods: Evidence from Regional Inequality in Tunisia. African Development Review, 29, 4: pp. 660-673.

LAHIANI, O. 2018. No poverty map in Algeria. Al Arabi Al Jadid. Available at: https://www.alaraby.co.uk/ Accessed on 28 February 2021.

MEDDEB, H. 2020: The Geography of anger in Tunisia: Regional inequality and the rise of populism. Beirut: Malcolm H. Kerr Carnegie Middle East Center. Available at: https://carnegieendowment.org/files/2-17-Meddeb_Tunisia.pdf . Accessed on 01 March 2021

MEDDEB, H. 2021: Life on the edge: How protests in Tataouine forced Tunis to back down.

- Beirut: Malcolm H. Kerr Carnegie Middle East Center. Available at: https://carnegiemec.org/2021/02/01/life-on-edge-how-protests-in-tataouine-forced-tunis-to-back-downpub-83768 Accessed on 01 March 2021.

OKKEZ, M. 2015: December 2010-December 2015: A Triangular of poverty and marginalization. Nawaat. Available at: https://nawaat.org/2015/12/18/ . Accessed on 01 March 2021.

WEI, Y. 2015: Spatiality of Regional Inequality. Applied Geography 61: pp. 1-10.

\section{Youtube videos (in Arabic)}

ZAGORA NEWS (2017, October 9). هكذا تطورت الاحداث بز اكورة بعد وقفة للمطالبة بالماء الصالح للشرب. Available at: https://www.youtube.com/watch?v=PnkPt1SCQ80\&t=250s . Accessed on 26 February 2021.

TACH YASSINE (16 June 2020). شباب و أهالي تين زواتين اليوم. Available at: https://www.youtube.com/watch?v=5ALKJpkoLtQ\&t=1s . Accessed on 28 February 2021. 
MOSAIQUE FM (21 May 2017). معتصمو الكامور يغلقون وحدة ضخ البترول. Available at: https://www.youtube.com/watch?v=oFHVyNzKyEw\&t=3s . Accessed on 01 March 2021.

زاكورة ZAGORA (11 October 2017). زاكورة تنتفض وتعلنها ثورة ضد العطش. Available at: https://www.youtube.com/watch?v=qSqdphP-v5M . Accessed on 26 February 2021. 


\title{
Measuring inequalities in access to water and sanitation: A literature review of the quantitative studies published in 2015-2020 Urangoo BULGAMAA ${ }^{13}$
}

\begin{abstract}
Research students who are interested in the topic of inequalities in water and sanitation are often interested in getting familiar with the most recent methods applied in empirical research. To address this need, this study aims to provide an overview of contemporary quantitative measures by synthesising the most recent empirical studies conducted on inequalities in access to water and sanitation across and within countries over time. The study aims to cover neither comprehensive nor exhaustive statistical details of the measures. Rather, it asks what measures were used recently in which type of studies and why. To this end, the paper adopted a content analysis technique framed by the three classifications of inequalities to review the selected empirical academic papers that were published in peer-reviewed, Scopus-indexed journals in 2015-2020 in the English language and were accessible by the author. Findings revealed that geographic, economic, and individual- and group-related inequalities in access to water and sanitation have been studied by applying the simple and sophisticated measures in both absolute and relative terms. However, their techniques were varied. In the end, the review suggests two possible directions for further research.
\end{abstract}

Keywords: inequality, water, sanitation, measurement, quantitative technique.

\section{Introduction}

In July 2010, the United Nations General Assembly declared that equitable access to water and sanitation is a human right, and that as such, ensuring such access to everyone plays an important role in the realisation of all human rights (UN GENERAL ASSEMBLY 2010). Furthermore, it plays an important role in public health by preventing people from catching infectious diseases (LOCAL BURDEN OF DISEASE WASH COLLABORATORS 2020). However, inequalities in access to water and sanitation continue to face a great deal of challenges, particularly in developing countries (WWAP UNESCO 2019). Lacking access to these services makes people even more vulnerable during the current COVID-19 pandemic, as hand hygiene is the first line-defence in fighting against this infectious disease, which is potentially fatal and has no cure presently proven to be effective (VIJAYVARGIYA et al. 2020).

In tackling the problem of inequality, UN-led global efforts have been made since the 1990s and have escalated since the 2000s through major programmes including the Millennium Development Goals (2000-2015) and Sustainable Development Goals (2016-2030). To measure progress towards the targets, scientific research plays an important role by providing

${ }^{13}$ Corvinus University of Budapest, Doctoral School of International Relations and Political Science, PhD candidate urangoo.corvinus@gmail.com 
policymakers relevant evidence to inform related decisions at both national and multilateral levels. The same is true in the case of water and sanitation. For those who are interested in applied research within the UN framework, particularly focusing on the SDG 6 (WWAP UNESCO 2019), knowing practical methodologies being applied in the practice is extremely important.

In attempting to address this need, I chose the period 2015-2020 to review what measures are being used in research tackling various types of inequalities in access to water and sanitation. Since comparative study is of interest, the chapter discusses the quantitative studies due to their methodological rigour. However, this review is neither a comprehensive summary nor does it provide exhaustive statistical details of these measures. Building on the three classifications of income inequality that pertain to the conditions of 'within-countries', 'between-countries' and 'global inequality among peoples' (UNDP 2003), I look at the measures being applied to the selected studies.

Findings revealed that geographic and economic inequalities in access to water and sanitation have mostly been estimated by a quantitative method based on cross-sectional and panel designs covering the sub-national, national, regional ${ }^{14}$ and global scales rather than the individual and group related inequalities that may still have an important policy relevance. These studies have applied both simple and sophisticated measures adapted to inequalities in access to water and sanitation in both absolute ${ }^{15}$ and relative terms ${ }^{16}$. The further details can be found in section 3 .

The structure of the paper is as follows: in the following section, the methods and materials used in this analysis will be briefly introduced, and then section 3 directs you to the main findings. Finally, the paper will be concluded.

\section{Materials and methods}

\subsection{Data}

This paper asks what measures were used for quantifying what type of inequalities in water and sanitation between 2015 and 2020, and why. To answer this question, I reviewed the recent relevant literatures. I first surveyed the selected papers for the review and then analysed

\footnotetext{
${ }^{14}$ Regional scale refers to the studies that analyzed the issue under analysis at the regional level such as Latin America. It is worth noting that some studies used data disaggregated into the regions (such as East, West...) at the sub-national level such as western or eastern regions within a country. Therefore, these two should not be mixed and misunderstood.

${ }^{15}$ In terms of absolute measures: the variance.

${ }^{16}$ In terms of relative measures: the Gini coefficient, Lorenz curve, Theil coefficient, Slop index etc.
} 
its content by mapping the inequality measures as to the three classification of inequalities (UNDP 2003) as informed by GREIG et al. (2007). Then I looked in detail how the different types of inequalities have been studied with respect to applied measures, scales, data, whether a causality was established. Lastly, I drew my conclusions.

The Scopus database was used to identify the relevant literatures in English language, available to date under the term described (inequality OR inequalities AND "water and sanitation"). Data was collected between September 20 - October 16. 2020. Taking the reliability and replicability of the sources relevant to the issue under scrutiny into consideration, the Scopus database was selected. CRESWELL (2003, p. 8) highlighted that considering standards of validity and reliability is crucial when it comes to quantitative research. Furthermore, there are systematic reviews using only Scopus database among the high-quality studies published in top-ranking journals such as Policy Sciences ${ }^{17}$, for example: DERWORT and his colleagues (2019) published such a work. I therefore consider that using Scopus database is sufficient for this paper. For making sure the sample size, the pool of 5 years old papers was checked against the pool of 10 years old papers in the same category in the same database. The result showed that the initially selected data pool weighs 78 per cent of the total published papers over the past decade. Therefore, it is assumed to be sufficient.

\subsection{Study selection}

I coded all the papers extracted $(n=125)$ from the Scopus following the keyword search ${ }^{18}$ under the search term previously described. They are classified by the sub-categories that can reflect the inclusion and exclusion criteria.

In surveying the literature, I followed the three-stages screening strategy (keyword search, title and abstract level analysis, and in-depth review) and included the articles, if that qualifies the inclusion criteria. The process of selection and the number of the articles were illustrated by Figure 4. Firstly, the screening was conducted by applying the following inclusion criteria $(1,2)$, which left 67 studies for further screening and excluded 58 studies due to the type and date of publication $(1,2)$. Then, the title and abstract level analysis used to narrow the 67 articles into 14 for the final stage by applying the inclusion $(3,4,5)$ and exclusion

\footnotetext{
${ }^{17}$ Policy Sciences is a journal which was ranked at the Q1 in 2019 by Scimago Journal Ranking. Retrieved from https://www.scimagojr.com/journalrank.php?area=3300\&min=0\&min_type=cd (09.25.2020).

${ }_{18}$ Database used: https://www.scopus.com/search/form.uri?display=basic; keywords used in search: (TITLEABS-KEY (inequality) OR TITLE-ABS-KEY (inequalities) AND TITLE-ABS-KEY ("water and sanitation")).
} 
criteria $(1,2,3)$. At this stage, 53 articles were excluded with the reasons. Finally, the papers selected $(n=14)$ were reviewed in-depth.

\subsection{Inclusion and exclusion criteria}

The inclusion criteria were the following:

1. Peer-reviewed journal articles (not the review articles)

2. Published between January 2015 and October 2020

3. If a paper addressed any type of inequalities in access to water and sanitation, regardless causality was established in its scope

4. If a quantitative method was applied to an empirical study

5. Whether the paper (full text) is accessible by the author.

The exclusion criteria were the following:

1. Review articles published in peer-reviewed journals

2. Published before 2015

3. If the scope of study did not cover an issue of inequalities in access to "water and sanitation" at one point,

4. If qualitative methods were applied,

5. If a full text of the paper is not available to the author.

\section{Results}

This chapter seeks to understand what type of summary measures being applied in recent international research in measuring what type of inequalities in access to water and sanitation by reviewing the relevant literature. In addition, the advantages and disadvantages of these measures under their categories were discussed.

The review immediately illustrates three types of inequalities in access to those services such as geographic inequalities (1), economic inequalities (2) and individual and group related inequalities (3). Among these, geographic and economic inequalities have been more widely studied in a quantitative fashion than that of the individual and group-related inequalities such as health condition and race. In particular, spatial inequalities and wealth or income-based inequalities have been dominant because the data is the strongest in this particular direction (ODI 2017).

These studies, in general, have evaluated the progress towards realisation of the global water and sanitation goals in the framework of MDGs and SDGs in the different scales using 
various measures in order to highlight the gaps in access to water and sanitation facilities between the different groups by rural and urban areas, by wealth, by regions, by the groups such as health status and race with the different resolutions depending on the basic unit of data that were used in the analyses.
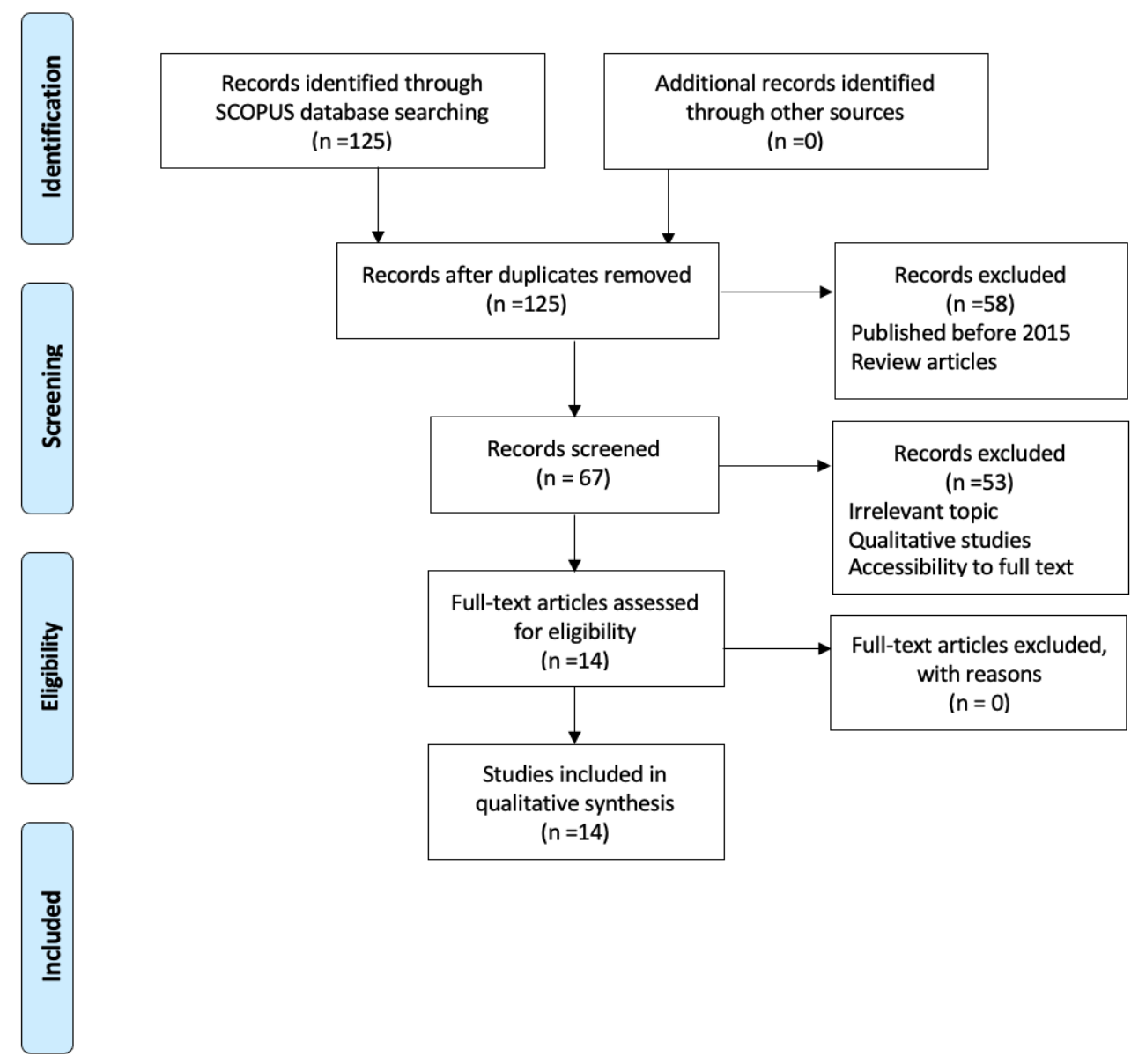

Figure 4: Flow diagram of the selection process of the papers Note: Adapted from the PRISMA flow diagram Source: http://prisma-statement.org/PRISMAStatement/FlowDiagram.aspx

All studies under review estimated various types of inequalities in access to water and sanitation using various techniques in the different scales. Most of these studies further established some sort of causality in which the various estimates of inequalities in an issue of interest were considered either a dependent or an independent variable. For example, CHA and the colleagues (2017) analysed the impact of official development assistance on the inequalities in access to water and sanitation across developing countries by applying simple linear regression, on the basis of multiple international datasets. In this study the inequalities were estimated by the simple disaggregation (Table 1, No. 8). 
A few methodological discussions were found that sought to propose alternative methods (QUEIROZ et al.2020) or look for a better measure that can be adapted to inequalities in access to water research (CETRULO et al. 2020). These studies shared a common rationale with respect to seeking that the principles of non-discrimination and equality ${ }^{19}$ to be better imbedded in the measurement - which lack in the current dominant JMP method ${ }^{20,21}$ in terms of equity perspective. However, it should be noted that the JMP method still provides valuable understanding on wealth-based inequalities through JMP wealth quintile approach ${ }^{22}$ (ODI 2017, p. 14), and the JMP wealth quintile datasets (see BAYU et al. 2020) were still utilised in recent research published.

QUEIROZ and colleagues (2020, p. 3) elaborated on this issue in terms of their suggested approach. They stated that there is lack of necessary data available to feed the explanatory variables in their suggested approach which goes beyond access related inequalities. This point addresses an intersection of inequalities in water and sanitation. It may explain why it is rare to observe quantitative studies that explore individual and group related inequalities in access to water and sanitation in comparison to the quantitative studies ODI (2017). This suggests a new opportunity for research if one can solve the associated data gap. However, it is worth noting that having comparable data on the multiple countries for this purpose will require an immense amount of resources and capacity, an obstacle which is extremely hard to tackle.

A number of different summary measurement techniques were used in the literature under review, with several of them repeatedly used in the same estimation. These are summarised under (Table 1).

\footnotetext{
${ }^{19}$ Which is the basis of SDG 6 - access to water and sanitation for all.

${ }^{20}$ It is important to note that the JMP is not a focus of our study and not dominantly used in the studies under this review, although it has been a dominant global monitoring strategy. However, some of the studies that addressed its limitations were discussed in this literature review.

${ }^{21}$ JMP method is the UN global monitoring strategy that is used to monitor progress on water, sanitation, and hygiene. To measure inequalities in access to water and sanitation facilities, it disaggregates household data by rural and urban areas (1), and by wealth status (2). This, the simple disaggregation method, allows both spatial inequalities between rural and urban areas, while the JMP wealth quintile analysis provides valuable understanding on the differential access among the groups based on their economic status. The further details can be consulted in the latest version of the methodology document available at https://washdata.org/sites/default/files/documents/reports/2018-04/JMP-2017-update-methodology.pdf.

${ }^{22}$ The JMP Wealth Quintile Analysis is a widely used approach in accounting geographic and economic inequalities in water and sanitation research. You can read its advantages and disadvantages in the ODI Report (ODI 2017).
} 


\begin{tabular}{|c|c|c|c|c|c|c|c|c|c|}
\hline$\stackrel{\circ}{z}$ & 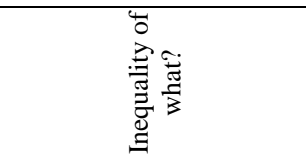 & 总首 & 离总 & 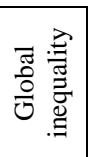 & 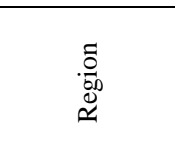 & 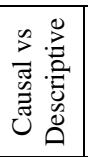 & 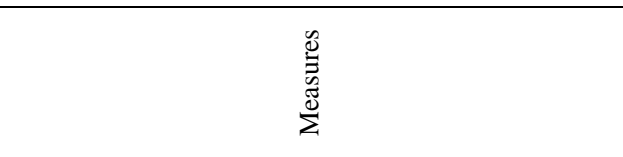 & 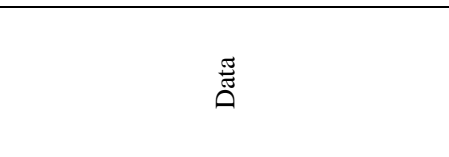 & 离 \\
\hline 1 & $\begin{array}{l}\text { geographic (spatial), } \\
\text { economic inequalities }\end{array}$ & $\mathrm{x}$ & & & Brazil & $\mathrm{D}$ & $\begin{array}{c}\text { Comparison of } 5 \text { measures made: simple } \\
\text { disaggregation, Concentration coefficient and } \\
\text { concentration curve, Dissimilarity index, Generalised } \\
\text { Entropy measure and Atkinson's index. } \\
\end{array}$ & Census, NSO Brazil & CETRULO et al. (2020) \\
\hline 2 & $\begin{array}{l}\text { individual and group- } \\
\text { related inequalities (race) }\end{array}$ & $\mathrm{x}$ & & & USA & $\mathrm{C}$ & OLS linear regression & Census housing, U.S.- ACS & GASTEYER et al. (2016) \\
\hline 3 & $\begin{array}{l}\text { individual and group- } \\
\text { related inequalities } \\
\text { (health conditions) }\end{array}$ & $\mathrm{x}$ & & & $\begin{array}{l}\text { Ethiopia, } \\
\text { Wukro }\end{array}$ & $\mathrm{C}$ & Pearson's Chi-squares, Logistic regression & Primary data & $\begin{array}{l}\text { JIMENEZ-REDAL et al. } \\
\text { (2018) }\end{array}$ \\
\hline 4 & $\begin{array}{l}\text { individual and group- } \\
\text { related inequalities } \\
\text { (intersecting) }\end{array}$ & $\mathrm{x}$ & $\mathrm{x}$ & & $\begin{array}{l}\text { Latin } \\
\text { America and } \\
\text { the Caribbean }\end{array}$ & $\mathrm{C}$ & Simple linear regression & Census IPUMS project & QUEIROZ et al. (2020) \\
\hline 5 & geographical (temporal) & $\mathrm{x}$ & $\mathrm{x}$ & & $\begin{array}{l}\text { Developing } \\
\text { countries }\end{array}$ & $\mathrm{C}$ & Non-linear trajectory & $\begin{array}{l}\text { DHS, MICS, nationally representative } \\
\text { household survey - JMP data }\end{array}$ & FULLER et al. (2016) \\
\hline 6 & geographical (spatial) & $\mathrm{x}$ & & & India & $\mathrm{D}$ & $\begin{array}{c}5 \text { different measures: simple disaggregation, adapted } \\
\text { Gini coefficient, Dissimilarity index, Spatial } \\
\text { correlation, Analysis of agglomerative hierarchical } \\
\text { clusters }\end{array}$ & Census, India & $\begin{array}{l}\text { CHAUDHURI and ROY } \\
\text { (2017) }\end{array}$ \\
\hline 7 & $\begin{array}{l}\text { geographic (spatial), } \\
\text { economic }\end{array}$ & $\mathrm{x}$ & & & India & $\mathrm{C}$ & $\begin{array}{l}\text { Gini coefficient, Spatial correlation, Percentage point } \\
\text { difference, a composite index developed was used to } \\
\text { measure the effect. }\end{array}$ & Census, India & $\begin{array}{l}\text { CHAUDHURI et al. } \\
\text { (2020) }\end{array}$ \\
\hline 8 & $\begin{array}{l}\text { economic (income } \\
\text { based) }\end{array}$ & & $\mathrm{x}$ & & $\begin{array}{l}\text { Developing } \\
\text { countries }\end{array}$ & $\mathrm{C}$ & Simple disaggregations, Simple linear regression & $\begin{array}{c}\text { WHO coverage data, OECD CRC } \\
\text { database }\end{array}$ & CHA et al. (2017) \\
\hline 9 & $\begin{array}{l}\text { economic (income } \\
\text { based) }\end{array}$ & & $\mathrm{x}$ & & $\begin{array}{l}\text { Developing } \\
\text { countries }\end{array}$ & $\mathrm{C}$ & Adapted Gini-coefficient, Multivariate regression & $\begin{array}{c}\text { JMP wealth quintile data, WGI-World } \\
\text { Bank }\end{array}$ & BAYU et al. (2020) \\
\hline 10 & $\begin{array}{l}\text { geographic (spatial), } \\
\text { economic }\end{array}$ & & $\mathrm{x}$ & & $\begin{array}{l}\text { Sub-Saharan } \\
\text { Africa }\end{array}$ & $\mathrm{D}$ & $\begin{array}{l}\text { Concentration index, frequency ratios, percentage } \\
\text { point differences }\end{array}$ & MICS, DHS & ROCHE et al. (2017) \\
\hline 11 & geographical (spatial) & $\mathrm{x}$ & & & Indonesia & $\mathrm{D}$ & $\begin{array}{l}\text { WHO-the mean difference from mean (MDM), } \\
\text { WHO-the weighted index of disparity (IDIS - W) }\end{array}$ & SUSENAS, Indonesia & AFIFAH et al. (2018) \\
\hline 12 & geographical (spatial) & $\mathrm{x}$ & & & Ethiopia & $\mathrm{D}$ & $\begin{array}{l}\text { WHO-the mean difference from mean (MDM), } \\
\text { WHO-the weighted index of disparity (IDIS - W) }\end{array}$ & $\begin{array}{l}\text { EDHS, Ethiopia CSA, nationally, } \\
\text { regionally representative }\end{array}$ & AZAGE et al. (2020) \\
\hline 13 & geographical (spatial) & $\mathrm{x}$ & & & Nepal & $\mathrm{C}$ & $\begin{array}{l}\text { Complex survey design method, Pearson's Chi- } \\
\text { squares, Simple regression }\end{array}$ & DHS Nepal survey & WANG et al. (2019) \\
\hline 14 & geographical (spatial) & $\mathrm{x}$ & $\mathrm{x}$ & $\mathrm{x}$ & $\begin{array}{l}\text { LMIC } \\
\text { (Low-middle } \\
\text { income } \\
\text { countries) } \\
\end{array}$ & $\mathrm{C}$ & $\begin{array}{l}\text { Adapted Gini-coefficient, Bayesian geostatistical } \\
\text { model, ordinal regression, }\end{array}$ & $\begin{array}{l}\text { MICS, DHS and other household } \\
\text { surveys, census }\end{array}$ & $\begin{array}{l}\text { Local Burden of Disease } \\
\text { WaSH Collaborators } \\
\text { (2020) }\end{array}$ \\
\hline
\end{tabular}

Table 1: List of inequality measures in access to water and sanitation applied to the studies under review

Source: Edited by the author.

Note: These studies were published between 2015 and 2020. 
The studies under review estimated inequalities in access to water and sanitation at the sub-national, national, regional, and global levels ${ }^{23}$. Global and regional scale studies mostly looked at inequalities 'within countries' and 'between countries' based on the country level data and sub-national data in which they were disaggregated by rural and urban areas (CHA et al. 2017; BAYU et al. 2020; FULLER et al. 2016; QUEIROZ et al. 2020; ROCHE et al. 2017; LOCAL BURDEN OF DISEASE WASH COLLABORATORS 2020).

Among these, recently published study conducted by the Local Burden of Disease WaSH Collaborators (2020) managed to disaggregate geographical inequalities globally by the first and second local administrative units - which is a high-resolution geospatial estimate ${ }^{24}$. This study, notably, was funded by the Gates Foundation among others and conducted in collaboration with hundreds of international researchers.

Moving on a country level analysis, 8 papers were identified in this category that covered both developed and developing countries. It is notable to reveal that the inequalities in access to water and sanitation are not only existing in the countries that are economically weak (CETRULO et al. 2020; AZAGE et al. 2020; AFIFAH et al. 2018; CHAUDHURI et al. 2017; CHAUDHURI et al. 2020; JIMENEZ-REDAL et al. 2018; WANG et al. 2019) but also in an advanced economy such as the United States of America (GASTEYER et al. 2016).

\section{Why are these measures? What are the advantages/disadvantages of these measures?}

Some of these measures were adapted from the other research areas such income and health inequalities, which has a relatively longer tradition than that of water and sanitation research. For example, adapted Gini coefficient, Concentration Index and summary measures of inequalities in relative and absolute terms (ODI 2017). In general, summary measures of inequalities in access to water and sanitation that were reviewed in this chapter can be grouped into three categories: simple measures (1), regression-based measures (2) and complex measures (3) as most of them overlap what were used in the literatures in health inequalities (LKHAGVASUREN 2018).

In their work of 1997, MACKENBACH and KUNST (pp. 759-760) noted that the simple measures such as rate difference and rate ratio, have advantages of easier calculation, straight

\footnotetext{
${ }^{23}$ Those scales of analysis - the sub-national, national, regional and global levels - have no special correlation on selection of the measures. On the contrary, which have a strong relevance to the level of disaggregation and coverage of the data.

24 For more information, see: GeoNetwork The Global Administrative Unit Layers (GAUL). http://www.fao.org/geonetwork/srv/en/main.home as informed by the Local Burden of Disease WaSH Collaborators (2020).
} 
forward interpretation, having less restriction to justify the data to be used in analyses, and measurement of the independent variables can be on ordinal or nominal scales. They also have disadvantages of misinforming parts of available information in data. On the contrary, although the regression-based measures can better address the problem of miscommunicating already available information in data, these measures still face disadvantages of more complexity in calculation and the restrictions on the data to be used in analysis. Furthermore, a regressionbased index would need the variables on an interval scale - that can cause an additional burden.

As LKHAGVASUREN explained in her work (2018, p. 58) the regression-based measures are used to analyse the association between the dependent and independent variables of interest, while complex measures such as concentration index, Atkinson's index and Thiel Index reflect socioeconomic dimension to health inequalities. These measures were also compared in CETRULO and colleagues' work (2020) in searching for a better measure for estimating inequalities in access to water within the SDG 6 framework as an alternative to the JMP method.

Furthermore, more than a half of the studies $(n=9 / 14)$ under review further established a causality, thus they used the different types of regression-based analysis that include linear regression, non-linear trajectory, OLS linear regression, logistic regression and multivariate regression (GASTEYER et al. 2016; JIMENEZ-REDAL et al. 2018; QUEIROZ et al. 2020; FULLER et al. 2016; CHA et al. 2017; BAYU et al. 2020; WANG et al. 2019; and LOCAL BURDEN OF DISEASE WASH COLLABORATORS 2020), while one study developed and applied a specific index to measure the effect (CHAUDHURI et al. 2020). The selection of the type of measure reflects the number of variables and the design of the study. For example, linear regression was used to test an association between a dependent variable and an independent variable, while logistic regression was used when there is a binary variable. Therefore, I found no single measure but a variety of techniques which are consistent with the context and design of the study.

This is also worth mentioning the types of data and database. These studies utilised mostly were cross-sectional and panel datasets. Which were obtained from the open-access datasets (i) that are maintained and stored by the international organisations such as the WHO, UN, USAID and OECD (FULLER et al. 2016; CHA et al. 2017; BAYU et al. 2020; ROCHE et al. 2017; WANG et al. 2019) or an international project such as IPUMS (QUEIROZ et al. 2020); data from the national statistical offices (ii) (CETRULO et al. 2020; AFIFAH et al. 2018; GASTEYER et al. 2016; CHAUDHURI et al. 2020; CHAUDHURI et al. 2017; AZAGE et al. 2020) or combination of all (LOCAL BURDEN OF DISEASE WASH 
COLLABORATORS 2020). These were all secondary data utilised in these studies. However, only one study used primary data by collecting it during the research (JIMENEZ-REDAL et al. 2018).

\section{Conclusion}

The chapter presents an overview of the recent quantitative measures applied in research on inequalities in access to water and sanitation based on the synthesis of the most relevant empirical literature. The advantages and disadvantages of these measures were briefly discussed. Findings revealed that the multiple techniques framed by the statistical models were utilised to report the progress towards tackling inequalities in access to water and sanitation and analysing a causality established. Both simple and sophisticated measures were used in relative and absolute terms for the studies covering different regions, scales, and the types of inequalities. A few papers offered alternative methods and a possibility to adapt a better measurement technique that may address some of the limitations of the JMP method. The data gap is one of the major challenges involved in addressing such a problem. This information is hopefully helpful to the research students and professionals who are interested in the water and sanitation topic and being in the stage of designing their projects. As a recommendation for further research, I would suggest two directions. First, group and individual related inequalities have rarely been quantified, partly because of the data gap and partly because of the methodological challenges. Second, there is certainly a need for a methodological contribution to measuring different types of inequalities in access to water and sanitation that takes account of the principle of non-discrimination and inequality, which is consistent with working towards achieving universal access.

\section{Funding}

The present publication is the outcome of the project "From Talent to Young Researcher project aimed at activities supporting the research career model in higher education", identifier EFOP-3.6.3-VEKOP-16-2017-00007 co-supported by the European Union, Hungary and the European Social Fund. 


\section{References}

AFIFAH, T. - NURYETTY, M.T. - CAHYORINI - MUSADAD, D.A. - SCHLOTHEUBER. A. - BERGEN. N - JOHNSTON, R. 2018: Subnational regional inequality in access to improved drinking water and sanitation in Indonesia: results from the 2015 Indonesian National Socioeconomic Survey (SUSENAS). Global Health Action 11(1): pp. 31-40. https://doi.org/10.1080/16549716.2018.1496972

AZAGE, M. - MOTBAINOR, A. - NIGATU, D. 2020: Exploring geographical variations and inequalities in access to improved water and sanitation in Ethiopia: mapping and spatial analysis. Heliyon 6(4): p.e03828. https://doi.org/10.1016/j.heliyon.2020.e03828

BAYU, T. - KIM, H. - OKI, T. 2020: Water Governance Contribution to Water and Sanitation Access Equality in Developing Countries. Water Resources Research 56(4): https://doi.org/10.1029/2019WR025330

CAWTHORNE, K.R. - COOKE, R.P. 2020: Innovative technologies for hand hygiene monitoring are urgently needed in the fight against COVID-19. Journal of Hospital Infection 105(2): pp. 362-363. https://doi.org/10.1016/j.jhin.2020.04.005

CETRUlO, T.B. - MARQUES, R.C. - MALHEIROS, T.F. - CETRULO, N.M. 2020: Monitoring inequality in water access: Challenges for the 2030 Agenda for Sustainable Development. Science of The Total Environment 727, p. 138746. https://doi.org/10.1016/j.scitotenv.2020.138746

CHA, S. - MANKADI, P.M. - ELHAG, M.S. - LEE, Y. - JIN, Y. 2017: Trends of improved water and sanitation coverage around the globe between 1990 and 2010: inequality among countries and performance of official development assistance. Global Health Action 10(1): p. 1327170. https://doi.org/10.1080/16549716.2017.1327170

CHAUDHURI, S. - ROY, M. 2017: Rural-urban spatial inequality in water and sanitation facilities in India: A cross-sectional study from household to national level. Applied Geography 85: pp. 27-38. https://doi.org/10.1016/j.apgeog.2017.05.003

CHAUDHURI, S. - ROY, M. - JAIN, A. 2020: Appraisal of WaSH (Water-SanitationHygiene) Infrastructure using a Composite Index, Spatial Algorithms and Sociodemographic Correlates in Rural India. Journal of Environmental Informatics 35(1): https://doi.org/10.1177/0973005220946661

CRESWELL, J.W. 2003: Research design: Qualitative, quantitative, and mixed methods approaches. California- London- New Delhi: Sage publications. 
DERWORT, P. - JAGER, N. - NEWIG, J. 2019: Towards productive functions? A systematic review of institutional failure, its causes and consequences. Policy Sciences 52(2): pp. 281298. https://doi.org/10.1007/s11077-018-9339-Z

FULLER, J.A. - GOLDSTICK, J. - BARTRAM, J. - EISENBERG, J.N. 2016: Tracking progress towards global drinking water and sanitation targets: A within and among country analysis. Science of the Total Environment 541: pp. 857-864. https://doi.org/10.1016/j.scitotenv.2015.09.130

GASTEYER, S.P. - LAI, J. - TUCKER, B. - CARRERA, J. - MOSS, J. 2016: Basics inequality: Race and access to complete plumbing facilities in the United States. Du Bois Review: Social Science Research on Race 13(2): pp. 305-325. https://doi.org/10.1017/S1742058X16000242

GREIG, A. - HULME, D. - TURNER, M. 2007: Challenging global inequality: Development theory and practice in the 21st century. London: Macmillan International Higher Education JIMENEZ-REDAL, R. - HOLOWKO, N. -ALMANDOZ, J. - ARREGUI, F. -MAGRINYA, F. 2018: Evaluating equity and inclusion in access to water and sanitation for persons living with HIV/AIDS in Wukro, Ethiopia. Water 10(9), p.1237. https://doi.org/10.3390/w10091237

LOCAL BURDEN OF DISEASE WASH COLLABORATORS. 2020: Mapping geographical inequalities in access to drinking water and sanitation facilities in low-income and middleincome countries, 2000-17. The Lancet. Global health 8(9): p.1162. https://doi.org/10.1016/S2214-109X(20)30278-3

LKHAGVASUREN, K. 2018: Essays on health inequalities and utilization of health service in low-and middle-income countries. Retrieved from: https://archives.kdischool.ac.kr/handle/11125/31249 (09.20.2020).

MACKENBACH, J.P. - KUNST, A.E. 1997: Measuring the magnitude of socio-economic inequalities in health: an overview of available measures illustrated with two examples from Europe. Soc Sci Med. 44(6): pp 757-71. PMID: 9080560. doi: 10.1016/s02779536(96)00073-1.

MOHER, D. - LIBERATI, A. - TETZLAFF, J. - ALTMAN, D.G. - PRISMA GROUP. 2009: Preferred reporting items for systematic reviews and meta-analyses: the PRISMA statement. PLoS medicine 6(7): p.e1000097. doi:10.1371/journal.pmed1000097

ODI (Overseas Development Institute). 2017: How to Reduce Inequalities in Access to WASH. Synthesis report. Retrieved from: https://cdn.odi.org/media/documents/11604.pdf (09.20.2020). 
QUEIROZ, V.C. - CARVALHO, R.C.D. - HELLER, L. 2020: New approaches to monitor inequalities in access to water and sanitation: The SDGs in Latin America and the Caribbean. Water 12(4): p. 931. https://doi.org/10.3390/w12040931

ROCHE, R. - BAIN, R. - CUMMING, O. 2017: A long way to go-Estimates of combined water, sanitation and hygiene coverage for 25 sub-Saharan African countries. PloS one 12(2): p. 0171783. https://doi.org/10.1371/journal.pone.0171783

UNDP. 2003: Human Development Report: Millennium Development Goals - A Compact Among Nations to End Human Poverty. Retrieved from: http://hdr.undp.org/en/content/human-development-report-2003 (09.20.2020).

UNITED NATIONS GENERAL ASSEMBLY. 2010: Resolution A/RES/64/292: The human right to water and sanitation. Retrieved from: https://undocs.org/A/RES/64/292 (09.20.2020).

UNICEF, WHO. 2018: JMP Methodology - 2017 update, SDG baselines. Retrieved from: https://washdata.org/sites/default/files/documents/reports/2018-04/JMP-2017-updatemethodology.pdf (05.01.2021).

VIJAYVARGIYA, P. - GARRIGOS, Z.E. - ALMEIDA, N.E.C. - STEVENS, R.W. RAZONABLE, R.R. 2020: Treatment considerations for COVID-19: A critical review of the evidence (or lack thereof). Mayo Clinic Proceedings, Elsevier. Retrieved from: https://els-jbs-prod-

cdn.jbs.elsevierhealth.com/pb/assets/raw/Health\%20Advance/journals/jmcp/jmcp_ft95_5 11.pdf (05.01.2021).

WAGSTAFF, A.- PACI, P. - VAN DOORSLAER, E. 1991: On the measurement of inequalities in health. Social Science \& Medicine, 33(5): pp. 545-557. https://doi.org/10.1016/0277-9536(91)90212-U

WANG, C. - PAN, J. - YADAC, R.B. - YAO, D. 2019: Geographic inequalities in accessing improved water and sanitation facilities in Nepal. International journal of environmental research and public health, 16(7): p.1269. https://doi.org/10.3390/ijerph16071269

WWAP UNESCO World Water Assessment Programme. 2019: The United Nations World Water Development Report: Leaving No One Behind. Retrieved from: https://unesdoc.unesco.org/ark:/48223/pf0000367306 (09.20.2020). 


\title{
The multidimensional poverty measurement in Latin America: A short introduction Ágnes DEÁK ${ }^{25} 26$
}

\begin{abstract}
Latin America, despite being a middle-income region, continues to face a number of social and economic problems, including poverty. The paper focuses on offering a panorama about the new forms of multidimensional poverty measurement introduced recently in Latin America. The main questions are the following: What traditions are the current methods based on? What are the peculiarities of the new indexes and their process of elaboration? The article explores the origins and some improvements which led to the currently used concept and measurement of multidimensional poverty in several Latin-American countries. Analyzing academic and official government expert documents it reviews and synthetizes the historical evolution of the methodology, the development of the new methods and the ways of how these can contribute to improve public policy decisions to effectively address the elimination of various forms of deprivation. It also offers a comparative study of different national measurements. The analysis shows that the process of elaboration of the new methods does not have a single scenario throughout Latin America. Although the participation process was far from complete, various spheres of the society were included. It is also documented that the new measurements took into account new dimensions and indicators of poverty that have not been considered so far.
\end{abstract}

Keywords: multidimensional poverty, poverty measurements, capability approach, Latin America

\section{Introduction}

In the last two decades, the international community has made significant achievements in eradicating global poverty. In parallel its attention gradually shifted towards the phenomenon of inequality which became one of the most current topics at the center of academic and public debates (ATKINSON 2015; MILANOVIC 2016). Nevertheless the fact that there are still millions living in unacceptable conditions makes the need to address the persisting problems of poverty a moral obligation for national and multinational institutions. ${ }^{27}$ The current Covid19 pandemic made the confrontation with the sudden and drastic rupture of economic, health and institutional systems in many countries around the world, hence the current health crisis has drawn special attention to the results achieved so far and the possibility of their rapid erosion (WORLD BANK 2020). At the international political level the UN-adopted Agenda for Sustainable Development Goals (SDG) in which the first goal is to end poverty in all its forms shows the global community is committed to its ethical duty (UN 2015). Interpreting the main objectives set out in SDG 1: "1.1 eradicate extreme poverty for all people everywhere and 1.2 reduce at least by half the proportion of men, women and children of all ages living in poverty in all its dimensions according to national definitions" means that it does not provide

\footnotetext{
25 Corvinus University of Budapest, Doctoral School of International Relations and Political Sciences, PhD student agnesdeak@yahoo.com

${ }^{26}$ I wish to thank Judit Ricz for her suggestions and insightful comments.

${ }^{27}$ It is important to note that the concepts of relative poverty and inequality are often confused. This may result from the fact that relative poverty is a definition that compares the situations of different social groups. Although poverty and inequality are interlinked, they are not synonymous and represent different phenomena.
} 
a uniform and unanimously accepted definition of what exactly is meant by multidimensional poverty, (apart articulating some expectations which should be accomplished such as 1.3 "have equal rights to economic resources, as well as access to basic services, etc.”) (UN 2015). Hence, each member state must define the dimensions and indicators to develop a methodology to measure them in order to be capable of implementing proper policies to achieve these objectives.

Academic research in recent decades has focused on three challenging sets of questions: 1. Reconsidering the conceptual framework of poverty beyond the monetary approach that was widely applied to international institutions. 2. Elaboration of more appropriate methods to measure multidimensional poverty. 3. Improving a complex public policy package relying on the integrated approach that focuses on people and enhancing their living conditions. It has become widely accepted (among the majority of scholars and also the public spheres) that poverty is a multidimensional phenomenon and that human deprivation takes many forms. As Amartya Sen states it: "the role of income and wealth... has to be integrated into a broader and fuller picture of success and deprivation" (SEN 1999, p. 37). This paper focuses on the second aspect. Recent changes and innovations have especially affected methodological issues, therefore the aim of this study is to explore, summarize and synthetize related changes. By focusing on new poverty measurement methodology introduced in the region over the last decade, the study aims to reveal the differences and the novelties between the original and more recent methodologies. Furthermore, it aims to provide a regional overview, revealing some aspects and difficulties of the elaboration of the current methodology, with special regard to the process of defining the different dimensions of poverty measurement. The problem of measuring development, poverty and quality of life has long been present in social science research, especially since the second half of the last century. However, the scientific debate and practice on this issue has gained new impulses in recent decades with the promising process of economic thinking that began to unfold as a result of the 2008-09 global crisis. An important milestone of the new renaissance was the Stiglitz-Sen-Fitoussi report ${ }^{28}$, which clearly drew attention to the fact that both technocratic and also political decisions (with regard to economic

\footnotetext{
${ }^{28}$ The Commission led by acknowledged social scientists Joseph Stiglitz (President of the Commission), Amartya Sen (Advisor) and Jean Paul Fitoussi (Coordinator) later called "The Commission on the Measurement of Economic Performance and Social Progress" (CMEPSP) was created as the request of the then President of the French Republic, Nicholas Sarkozy in 2008. The aim of The Commission was to enhance the formulation of a new methodological tool with more appropriate indicators that not only measures economic welfare such as GDP, but also people's quality of life and the social achievements. To complement GDP with a broader set of indicators that would reflect properly the distribution of well-being and its sustainability across its social, economic and environmental aspects in the society.
} 
policies) have been predominantly based on the overly one-sided and narrow concept and measures of development, most notably on GDP and related measures. The report made it clear that a new approach (including new statistical methods and data) is required to appropriately map socio-economic processes and thus to provide adequate information to decision-makers to elaborate proper public policies. As the report puts it "What you measure affects what you do; and if our measurements are flawed, decisions may be distorted" (STIGLITZ et al. 2009, p. 7). Reflecting the report and its main insight, namely that the importance of statistical data and indices have become decisive recently not only with regard the management of the economy, but also in terms of planning public policies to enhance social progress, new initiatives were launched, such as Global Multidimensional Poverty Index of OPHI and OECD Better Lives Initiative among others.

The Latin American region serves as a particularly interesting case study in terms of examining the evolution of multidimensional poverty measurement for various reasons: 1 . The negative socioeconomic effects of former neoliberal policies, which have added up to inherited development challenges, such as permanent high levels of informality and lack of access to services. 2. Latin America was the pioneering region where multidimensional measurement of poverty was first introduced in a form that took into account both income and unsatisfied basic needs indicators (BOLTVINIK 2013). 3. Following this long-standing tradition, several countries in the region have paid particular attention to developing their own new multidimensional poverty measurement. 4 . Research about trends of global poverty show the geographical distribution of the poor has changed significantly over the last two decades, with the result that the majority of them now live in middle-income countries (KANBUR SUMNER 2012). Latin America is a middle-income region, thus its countries' experiences can be especially valuable and provide some lessons for other countries with similar endowments. 5. In many Latin American countries national strategies to reduce poverty (as part of national development plans) were elaborated based on information revealed by multidimensional poverty measurements (on the characteristics of poverty at local and regional levels). The method's public policy relevance has also been highlighted during the localization and targeting of the conditional cash transfer programs ${ }^{29}$ beneficiaries.

This study aims to provide a critical review of academic literature and expert documentation. For the historical review, the documents were selected primarily from the

\footnotetext{
${ }^{29}$ The conditional cash transfer program was an innovative antipoverty strategy originating from Mexico in the 1990's and later, its various forms were introduced in many Latin-American countries and other regions (García and Moore, 2012).
} 
ECLAC $^{30}$ archives, focusing on the most significant milestones as well as on the work of some ECLAC experts. The analysis of the individual countries of the region is based on official expert and ministerial, governmental studies and publications documenting the advancement of the country specific methods, which provided also the opportunity to have a deep insight into the decision-making process. In addition, statistical data and publications reviewing changes of earlier decades were also analysed.

The paper includes three parts in addition to this introduction. The first provides an overview of the history of poverty measurement in the Latin American region. The following part presents the different forms of the multidimensional poverty measurements currently used by countries in the region. The final part concludes.

\section{The origins of the multidimensional poverty measurement in Latin America}

\subsection{The Unsatisfied Basic Needs Approach}

The origins of the basic needs approach (BNA) are linked to a field research of the International Labour Organization (ILO) in the 1970s under the World Employment Program (WEP) which revealed the precarious working and living conditions of significant part of societies in the then developing countries. In addition, by that time household-based surveys had not yet been developed and thus could not measure monetary poverty. The approach ${ }^{31}$, which ultimately did not take root globally only in the Latin American region, was first used in Chile in 1975. As a pioneering attempt it aimed to classify poverty within the BNA framework on the basis of living standards (household equipment, education, overcrowding) and, at the same time to document the geographical location of people living in extreme poverty (KAST - MOLINA 1975).

The next milestone of regional importance was the poverty survey conducted in Argentina by the Institute of Statistics and Census (INDEC) with the assistance of ECLAC in 1984. The ECLAC survey based on the questionnaire of a census already used in Argentina with information of income and non-monetary indicators, included the Unsatisfied Basic Needs (UBN) indicators: overcrowding, deficiencies in house equipment, lack of toilet, lack of school attendance and economic capacity (SANTOS 2014).

\footnotetext{
${ }^{30}$ Founded in 1948, the Economic Commission for Latin America (ECLAC, or CEPAL by its initials in Spanish) is one branch of the economic commission of the United Nations. See: https://www.cepal.org/en/about

${ }^{31}$ The idea was officially first published in a study as a document prepared for the ILO at the World Employment Conference in 1976 entitled "Employment, growth and basic needs-one world problem" (International Labour Office, 1978).
} 
As the goal in most Latin American countries was to map poverty by geographical location, so-called poverty maps were produced relying on data that originated from population and housing censuses in which UBN indicators were included. The four most typical out of these were: (1) Access to housing (2) Access to sanitary conditions (3) Access to education (4) Economic capacity. The basis of the UBN method, called the "counting approach", is the aggregation of the data collected on the population and household surveys, to determine who is poor by creating a composite index of UBN - which is called in most Latin-American countries as the "Index of Unsatisfied Basic Needs " (INBI Índice de Necesidades Básicas Insatisfechas). ${ }^{32}$ The method is simple, households that are classified in any (even one) dimension as having an unsatisfied need are considered poor, while those which are not represented in any category, are considered not poor (FERES - MANCERO 2001). The results were appropriate to diagnose the incidence of poverty and determine their geographical location, so these could serve as a basis for various policy decisions, especially in geographically targeting transfer programs introduced in the 90s throughout the Latin American region (COADY et al. 2004). However, it is important to note at least one disadvantage of the simplicity of this method: the INBI does not contain any information on the extent (and characteristics) of poverty. Hence it had no added value when elaborating comprehensive poverty eradication programs.

\subsection{The Integrated Method and the "Improved" Integrated Method}

Under the auspices of international institutions such as the World Bank, ILO and due to the availability of increasingly reliable statistics and the growing prevalence of population and household surveys, addressing and measuring poverty became an important task in the region. Oscar Altimir in collaboration with ECLAC identified absolute poverty in ten countries and across the region based on country-specific poverty lines representing minimum acceptable levels of private consumption, drawn according to the food-based method (ALTIMIR 1978). The study's normative definition of absolute poverty comprised of international expert

\footnotetext{
${ }^{32}$ UBN were measured in different dimensions and those in various variables: e.g. 1) a) quality of housing: variable: material of construction b) overcrowding variables: number of persons and number of rooms. It is important to note that economic capacity, as there were no or no reliable data on income, was basically measured by two variables: the level of education of the head of the family (given in years) and the number of those who were financially dependent on it.
} 
opinions and lifestyle opportunities for low-income families projected by regional development aspects. $^{33}$

In the 80 s a more complex approach emerged from research where the income and the UBN poverty measurement methods were combined in the so-called "Integrated Method" (BECCARIA - MINUJIN 1985; KATZMAN 1989). It was highlighted that significant difference might exist between the results of the two methods deriving from changes in longand short-term living conditions or from income fluctuations which depend on the macroeconomic circumstances of the country. ${ }^{34}$ Regarding Katzman's integrated method's classification, people living in poverty can be grouped into four distinct groups ${ }^{35}$ :

1. Chronically poor: this group is characterized by at least one, but typically more UBN were not satisfied with the persistently insufficient income; job insecurity and social marginalization.

2. Inertial deprivation: households in this group typically show insufficiency in one indicator related to one basic needs, their incomes are above the poverty line, and their deprivation is a consequence of past prolonged poverty situation.

3. Recently poor: includes households where per capita income is lower than the poverty line but do not have a UBN deficit, these homes are less at risk of perpetuating poverty.

4. Socially integrated: these are households whose income is sufficient for basic consumption needs and they have no unsatisfied indicator in any dimensions defined by the UBN method.

Empirical evidence showed that the two method complement each other and can be used to describe distinct subgroups of the population suffering from different forms deprivations in depth and breadth of poverty.

However, criticisms have been raised regarding the measurement and the conceptual overlaps in the integrated method (BOLTVINIK 1992). Accordingly, a new method was proposed, which significantly modified earlier ones and built upon their combination when elaborating the "Improved Integrated Method to Measure Poverty". The most important novelties were: 1. the addition of several new elements to the UNB indicators, e.g.: access to electricity, to phone, which were related to public expenditure, cumulative household investment; 2 . the creation of a much more comprehensive consumer basket (not just food, also

\footnotetext{
${ }^{33}$ The study evaluated that the 40 percent of Latin American households were poor at the beginning of the 1970s, with the incidence of poverty 26 percent in urban areas and 60 percent in rural areas. (ALTIMIR 1978)

${ }^{34}$ Beccaria and Minujin note that collecting income data is specifically cumbersome due to subdeclaration or to uncertainty in the size of the family.

${ }^{35}$ Katzman classification based on his empirical research conducted in Montevideo, Uruguay during the 80s.
} 
e.g. clothing, recreation); 3. the measurement of the depth of deprivation and the deprivation gap; 4. the alternative weights of the indicators; and 5. the time as a dimension was also considered in order to operationalize time poverty. Despite these improvements this method was introduced only in Mexico and it was not applied elsewhere in the region.

\section{Contemporary measurements of multidimensional poverty in Latin America}

\subsection{The new wave of multidimensional measurements}

The basic problem remained whether a single metric can be used to describe development, poverty and quality of life. This intention manifested in the fact that economic performance measures the value of goods and services acquired in the market, in which the prices are reflected in monetary terms. Those who consider that poverty and quality of life can be measured in this way use the poverty line method, which takes into account only household income and/or expenditure, on purchasing power. The poverty line is the most common measurement method in the developed world and it is also applied by the World Bank. In contrast, the United Nations Development Programme (UNDP) applies the Human Development Index (HDI) in its annual reports since 1990.

The HDI is already a multi-component (yet composite) index, and its creation reflected the goal of including several aspects of progress in one measure, according to the human development paradigm ${ }^{36}$ (STANTON 2007).

International development organizations have continued to be determined development and poverty primarily on monetary basis, while poverty eradication projects are essentially concentrating on human capital, and thus require other forms of data and measurement. As Boltvinik has put it, all the alternative ideas, which start from the fact that there is no single measurement indicator of development form a set of multidimensional approaches (BOLTVINIK 2013).

In multidimensional poverty measurement, there is a dividing line between two basic approaches to determining threshold or cut-off. One is the so-called union approach, according to which a person is considered poor if he or she is deprived in at least one dimension, while in the intersection approach one is considered poor when he or she is deprived in all

\footnotetext{
36 The human development paradigm originated in development economics research of the 70s and 80s, especially in the theoretical and practical work of Mahbub ul Haq (1995). It provides a people-centred perspective and represents an approach that takes into account the possibilities that enable a fulfilled human life. It has gained significance in the spread of UNDP development programs and by the creation of the Human Development Index.
} 
dimensions. Both approaches are extreme ideal types, so in most cases the reality is somewhere in between (ATKINSON 2003).

The primary field for the application of the results of academic research on development, such as the related new statistical methods and indices, are international institutions, where the innovations appear in competition with each other to enter the canon of applied methods of an organization. The global multidimensional poverty index (MPI) created by Oxford Poverty and Human Development Initiative (OPHI) has achieved one of the most successful careers in this competition ${ }^{37}$. The MPI, which complements money-based measures by considering multiple deprivations and their overlaps, was originally presented in the UNDP annual report 2010, The Real Wealth of Nations: Pathways to Human Development, claiming that poverty - like development - is multidimensional, yet this is traditionally ignored by headline figures (KLUGMAN 2010).

The global MPI was elaborated with the Alkire and Foster method (AF), and has become particularly recognized and applied during the last decade both globally, and also in Latin America the majority of countries adopted it.

The AF method is a synthetic method based essentially on the axiomatic tradition (ALKIRE - FOSTER 2011) and the counting approach. The essence of the method is to measure the different dimensions of poverty based on indicators. The method allows for flexibility and adaptability, as when defining dimensions, indicators, weights or cut-offs the different contextual factors of the given country or situation can be taken into account. It offers measures to determine the incidence of poverty (the percentage of the population who is poor), the intensity of poverty (the percentage of deprivations suffered by each person or household on average); adjusted poverty gap (the measure reflects the incidence, intensity and depth of poverty), adjusted squared poverty gap, (the measure reflects the incidence, intensity, and depth of poverty, as well as inequality among the poor). A further advantage of the AF method is that it can be broken down by population groups, either by geographical location, by ethnic group or by dimensions/indicators (ALKIRE et al. 2015; ALKIRE - FOSTER 2011). The theoretical and conceptual basis of the AF method is the capability approach, based originally upon the work of Amartya Sen. ${ }^{38}$ The capability approach "is an intellectual discipline that gives a central role to the evaluation of a person's achievements and freedoms in terms of his or her

\footnotetext{
${ }^{37}$ The Oxford Poverty and Human Development Initiative (OPHI) is an economic research and policy centre within the Oxford department of International Development at the University of Oxford. https://ophi.org.uk/about/.

38 Amartya Sen received the Nobel Prize in Economics in 1998 for his contributions to economic welfare and development economics research.
} 
actual ability to do the different things a person has reason to value doing or being" (SEN 2009, p. 16). Furthermore, Sen defines “...poverty as a deprivation of basic capabilities, rather than merely as low income. Deprivation of elementary capabilities can be reflected in premature mortality, significant undernourishment..." (SEN 1999, p. 37).

\subsection{The new wave arrives in Latin America}

In the last decade, multidimensional poverty measurements have been included in many Latin American countries as part of their official statistics. The first two countries that elaborated the methodology were Mexico and Colombia with introduction in 2009 and 2011, respectively. In the following years, several other countries published their similar poverty index: El Salvador in 2015, Chile, Costa Rica, Ecuador and Honduras in 2016, the Dominican Republic and Panama in 2017, and Guatemala in 2019. At the same time ECLAC as a regional institution has introduced significant initiatives over the years to develop a "general" multidimensional poverty index with the aim to enable detailed regional comparative analysis covering the Latin American region (CEPAL 2014; SANTOS 2014; SANTOS - VILLATORO 2018).

Although there is emerging consensus within academia and among experts of international institutions that a broader interpretation of poverty should be applied, there is still much debate about the appropriate approach, regarding the dimensions, and about the most appropriate measurement method. At the global level MPI serves not only for measuring poverty across regions and 100 countries worldwide, documenting its changes over time, but also to explore the different characteristics of deprivation. This latter information is essential for policymakers (OPHI and UNDP, 2019). At the national level governments aim to design a method which serves as a basis for more complex government social programs and targeted social projects. Considering all these assumptions a number of normative questions arise, that have to be answered during the further elaboration of measurement methodologies either at national or regional or global levels. Which should be the selected dimensions, which indicators determine a given dimension, what should be the deprivation criterion, should all the indicators and dimensions have unified into composite index or not? As in most cases, including Latin American countries, the result of the procedure is an index, it is also necessary to determine the weight of certain indicators and dimensions in the aggregation and to define the threshold identifying who is considered as poor in multidimensional sense. A related significant dilemma arises with regard who will determine and decide about all of these factors? The central agents shall come from the academia, or those in decision-making positions, who will use this tool to 
make public policy decisions, or on a more participatory manner should the opinion of the population of a given country taken in consideration, or only those living in poverty should be included? In addition, a number of feasibility issues need to be accounted for, which leads to different options for countries regarding their capacities: what is the institutional background for implementing the planned measurements, collecting and analysing the necessary data? Is there a long-term political will, a commitment to operate data collection? Answering these questions is a complex, multi-year process for each country, involving many actors.

Due to the short scope of the present study, it is not possible to explain and examine all aspects, whereas most Latin-American countries have introduced the multidimensional measurement method, in the following a more detailed observation is offered about the selection of dimensions and thresholds in some countries. The two forerunners of the region are highlighted: the Mexican method is unique, as it is not based on the AF method; whereas the Colombian case stands out, as its multidimensional measurement has been actively used for determining public policy goals.

As a starting point researchers or decision-makers need to explain very specifically why and how they have chosen certain dimensions (ROBEYNS 2005). Just as the capability approach emphasizes the extension of freedoms that people value, methodological definitions must also take into account what people value and have reason to value (ALKIRE 2007a). The principles most commonly accepted by researchers in the capability approach in selecting the dimensions of poverty are the following points: access to reliable data; continuous participatory and deliberative discussions about components of good life and wellbeing; constitutional foundations and/or national development plans of each countries; values expressed in universal documents of the international canon such as Universal Declaration of Human Rights, as well as postulates on concepts of the theory of justice, human good and wellbeing (ALKIRE et al. 2015). One of the most cited pioneering examples of global research based on the participatory research model is the Voices of the Poor (NARAYAN et al. 2000) study, which was valuable source of information about living conditions, problems of the vulnerable groups around the world. However, a number of questions arises about the feasibility, the reliability and the geographical limitation of this kind of data collection. This research also provided a more detailed picture of dimensions previously not represented by the measurements, which at the same time are decisive in the lives of the participants, especially noteworthy in the Latin American context the pervasive violence or social isolation. In many cases, the results of qualitative surveys have been considered in the elaboration of country-specific measurements. 
In Mexico, the process of introducing multidimensional poverty measurement was prepared by the General Law of Social Development adopted in 2004. Subsequently, the National Council for the Evaluation of Social Development Policy (CONEVAL) was set up to formulate the proper measurement. During the years of preparation, a number of debates took place, which included professionals, economists, statisticians, national and international experts in poverty research, but at the same time there was little role for public debate and consultation to include the most affected, the vulnerable groups of the population. The most decisive element on decision among some of the proposals, which were also discussed with the involvement of international experts from OPHI and ECLAC, was based on accordance with the Law and the Constitution. The methodology has two pillars: one, which measures economic welfare through the income indicator, and the other, which includes non-monetary social rights in six dimensions (see Appendix). The method also differs from the measurements accepted in the region in that it did not apply the aggregation and identification used by the AF method. According to this combined methodology, a person is considered poor if he or she is deprived in both non-monetary dimensions related to social rights and income measures (CONEVAL 2014). Mexico became the first country in the world to introduce multidimensional poverty measurement and established an independent state institution over the past decade to measure poverty and continuously evaluate social programs. In addition to the national level, the measurement of poverty also extends to the level of federal states and municipalities, so the most extensive data collection has been implemented at the territorial level so far in recent decades. Furthermore, regular measurements and transparent mechanisms make it possible to design public policy goals and strategies, such as the implementation of the National Strategy of Inclusion, National Policy of Social Development or infrastructural, housing project and food programs with targeted beneficiaries at local levels.

In Colombia, poverty reduction has been identified as one of the key objectives of the 2010 National Development Plan presented by President Juan Manuel Santos. To achieve this, new measurement methods were introduced in 2011: not only a completely new multidimensional poverty measurement has been elaborated by the National Planning Department, but also a new income poverty measurement was put forward.

A number of expert groups were involved in the process, including members of academia, the government and the private sector. Furthermore, it was explicitly aimed that the measurement should have characteristics that are appropriate for consistent analysis, change in public policy decisions, and a reflection of the current living conditions of Colombians. Preliminary proposals were then discussed with international experts, in particular with the 
internationally most recognized ones from OPHI (ANGULO 2016). The final version of the measurement consists of five dimensions (see Appendix), each defined by five indicators, whose data source is the Living Standards Measurements Survey. All indicators together determine the multidimensional poverty index using the AF method. The index assigns the same weight to each dimension (20\%) and the poverty line is considered at one-third of the weighted dimensions.

In setting the threshold, the subjective judgment of those who considered themselves deprived based on household surveys was taken into consideration (ANGULO et al. 2011). It is important to mention that this is the only measurement in the Latin American region which has put exceptional emphasis on a special dimension, namely the living conditions of children and young people. It is an important innovation which reflects the demographic conditions of the country. However, a significant shortcoming is that the dimension of violence and physical security was not included in this measurement. This happened despite the fact that number of acts of violence have particularly accompanied the modern history of the country (not just prior to the peace agreement with the FARC in 2016) and which made Colombia the second most affected country in the world by internal migration (WMR 2020). Furthermore, empirical research conducted by the participatory approach also revealed that for the poor living in Colombia, in addition to livelihood and education, the most significant deprivation is the persistent presence of violence and physical vulnerability (ARBOLEDA et al. 2004). The significance of the new method is shown by the fact that, as an indicator, it is a determining element of a number of important national social policies, such as the poverty and inequality reduction programs (e.g. early childhood care and food security programs) and also the geographical targeting of the conditional cash transfer program, called Más Familias en Acción.

The relevance of the method depends not only on its statistical elaboration, but also on the commitment of policy makers to public policy goals delineated on normative choices, the precise definition of the purpose of measurement, and the provision of an appropriate institutional background (ANGULO 2016).

It is important to note a special feature of the process of measurements developed in El Salvador and Ecuador. In both countries, the technical committees and the academic community that managed the process of selecting dimensions worked on a number of theoretical approaches. In the former case the process was complemented with a participative process based on focus group discussions organized for people living in poverty. In addition to the capability approach and human rights perspective, in both countries emphasis was placed 
on the Buen Vivir ${ }^{39}$ approach. Buen Vivir is one of the most important school of thoughts which gained high importance in reconsidering ideas of the development for Latin America over the last two decades. It is a complex concept, which has many cultural foundations, as well as relation with the cosmo-visions of the indigenous ethnic groups of the Andean and the Amazon territories. Three major versions are distinguished within the notion the indigenist, the statist and the post-developmentalist with their diverse intellectual origins, interrelationships, criticisms of each other (CARBONNIER et al. 2017). Its core ideology is living in harmony with the community and nature questioning and rejecting results of the classical theory and practices of economic development. The concept became a defining element of the most recent constitutions adopted in 2008 and 2009 in Ecuador and Bolivia. In the former, it also defines the framework of regularization and implementation for the social rights, which regulate access to education and housing among others and thus determine public policy.

A significant part of the dimensions and indicators used in the new methods also appeared regularly in the old UBN measurements, such as housing and home conditions, education (school years) or overcrowding. The new methods have broadened the dimensions used in the measurements not only in number but also operationalized through several indicators, thus allowing to document real and important aspects of the lifestyles of vulnerable groups of the population to emerge. Comparing the dimensions and indicators in the indices, we can see overlaps in many cases, but there are also unique components. The Appendix shows the dimensions of the indices compared to the global MPI and the previously used ones in UBN approach. Contrasted to the missing dimensions identified in the OPHI document such as quality of work, empowerment, physical security, shameless living, subjective and psychological well-being (ALKIRE 2007b) a number of advances can be observed e.g.: Chile, Costa Rica and Panama put emphasis on a labor rights and conditions, meanwhile physical security appears important for El Salvador and the Dominican Republic, the most violent region in the world according to homicide rate (CEPAL 2019). ${ }^{40}$ Indices for Chile, El Salvador, the Dominican Republic and Panama already include environmental indicators reflecting the exposure to effects of climate change and extractive industries. As to the weights of each dimension and indicator, with the exception of Mexico and Chile, nested weighting applies to all methods, according to which the weighting of dimensions and indicators (within a given

\footnotetext{
${ }^{39}$ In English: Good Living concept (see GUDYNAS and ACOSTA 2011).

${ }^{40}$ The Latin American homicide rate is 5 times higher than the world average. 22.1 homicides and 4.4 homicides per 100,000 people, respectively (CEPAL 2019, p. 47).
} 
dimension) is uniform. The case of Mexico is exceptional because the lack of any indicator there means dimensional deprivation. In Chile as a result of a modification the accepted version was modified under the pressure of civil groups. As a result, the dimension of social cohesion and networks was included into the original 4 dimensions, which also caused a change in the weighting ratio. The multidimensional poverty line varies between 20 and $35 \%$ of the weighted indicators (again with exception of Mexico) (see Appendix) ${ }^{41}$.

\section{Conclusion}

Analyzing the design process of multidimensional measurements applied across Latin America, it can be stated that these were implemented along different approaches, not according to a unified protocol. The construction of measures in most countries involved different spheres of society, in which expert committees such as members of the academia, policy makers from different levels and researchers from international organizations were given a prominent role. Although complete participation process was not achieved, civil society actors and vulnerable groups themselves were included in several cases. One of the obstacles to the development of multidimensional measurement methods is the lack of relevant data (ALKIRE 2007). Although most Latin American countries regularly collect data through their own household surveys, in order to include new dimensions and indicators in the measurements, the introduction of new set of questions in the questionnaires is required. Despite the fact that some steps in the development of multidimensional measurements, such as ensuring broad social participation or determining the dimensions, indicators and thresholds, etc. are subjects to ongoing debates among scholars, there is no doubt regarding the importance of creating and introducing them so far. There is a clear tendency for a multidimensional interpretation of poverty to emerge and gain weight alongside the use of monetary poverty.

The territorial approach, which goes back to the tradition of poverty maps applied in the region, has a number of benefits. As global poverty research confirms (KANBUR -SUMNER 2012) there is an increasing emphasis on subnational concerns to address poverty challenges within a country as a result of the highly territorial feature of poverty distribution. Measurement methods that take this into account will make it possible to develop more efficient local policies including well-defined specific targets.

The first aim of the SDG agenda, which is to significantly reduce poverty in its all forms, has reinforced the wider efforts to measure the phenomenon with a new approach at national

\footnotetext{
${ }^{41}$ The table in the Appendix does not include the indicators of measurements, only the dimensions.
} 
level. Latin American countries were particularly motivated and proactive, as the creation and implementation of new methodologies began there even before the global agenda was set. On the one hand, this is due to the practice of elaboration of poverty maps in several countries in the region in previous decades, on the other hand, due to openness to a new interpretation of poverty based upon the capability approach and to the acceptance of experience of international institutions. The new methods, which not only expanded the number of dimensions used in the conventional measurements, but also operationalized it through several new dimensions, allowed to take into account real and important aspects of the lifestyles of vulnerable groups of the population. This change in approach might allow public policy decisions to be made that can provide more effective solutions for those concerned.

\section{References}

ALKIRE, S. 2007a: Choosing dimensions: The capability approach and multidimensional poverty (Chronic Poverty Research Centre Working Paper No. 88). August 1, 2007.

ALKIRE, S. 2007b: The Missing Dimensions of Poverty Data: Introduction to the Special Issue. Oxford Development Studies 35, pp. 347-359. https://doi.org/10.1080/13600810701701863

ALKIRE, S. - FOSTER, J. 2011: Counting and multidimensional poverty measurement. Journal of Public Economics 95, pp. 476-487.

ALKIRE, S. - ROCHE, J.M. - BALLON, P. - FOSTER, J. - SANTOS, M.E. - SETH, S. 2015: Multidimensional poverty measurement and analysis. Oxford University Press, USA.

ALTIMIR, O. 1978: La Dimensión de la Pobreza en América Latina 124. https://repositorio.cepal.org/handle/11362/32250 (Accessed: 03.01.2020).

ANGULO, R. 2016: OPHI Working Paper No. 102 p. 27.

ANGUlO S., R.C.A. - CUERVO D. Y. - PARDO P. R. 2011: Índice de Pobreza Multidimensional para Colombia (No. 009228), Archivos de Economía. Departamento Nacional de Planeación.

ARBOLEDA, J.A. - PETESCH, P.L. - BLACKBURN, J. 2004: Voices of the Poor in Colombia: Strengthening Livelihoods, Families, and Communities. World Bank Publications, Washington, DC.

ATKINSON, A.B. 2015: Inequality: What can be done? Harvard University Press.

ATKINSON, A.B. 2003: Multidimensional deprivation: contrasting social welfare and counting approaches 15. Journal of Economic Inequality 1, pp. 51-65. 
BECCARIA, L.A. - MINUJIN, A. 1985: Métodos alternativos para medir la evolución del tamaño de la pobreza, Documento de trabajo No.6. United Nations Economic Commission for Latin America and the Caribbean, United Nations.

BOLTVINIK, J. 2013: Medición multidimensional de la pobreza. AL de precursora a rezagada. Revista Sociedad y Equidad 0. https://doi.org/10.5354/0718-9990.2013.26337

BOLTVINIK, J. 1992: El método de medición integrada de la pobreza. Una propuesta para su desarrollo. Comercio exterior 42, pp. 354-365.

BOLTVINIK, J. - DAMIÁN, A. 2020: Medición de la pobreza de México: análisis crítico comparativo de los diferentes métodos aplicados. Recomendaciones de buenas prácticas para la medición de la pobreza en México y América Latina. Available at: https://www.cepal.org/es/publicaciones/45555-medicion-la-pobreza-mexico-analisiscritico-comparativo-diferentes-metodos (Accessed: 03.01.2020).

CARBONNIER, G. - CAMPODÓNICO, H. - TEZANOS VÁZQUEZ, S. 2017: Alternative Pathways to Sustainable Development: Lessons from Latin America, Brill | Nijhoff, Leiden; Boston.

CASTILlO AÑASCO, R. - PÉREZ, F.J. 2015: Medición de la Pobreza Multidimensional en Ecuador. Available at: https://www.ecuadorencifras.gob.ec/documentos/webinec/Sitios/Pobreza_Multidimensional/assets/ipm-metodologia-oficial.pdf (Accessed: 03.01.2020).

CEPAL. 2019: Nudos críticos del desarrollo social inclusivo en América Latina y el Caribe: antecedentes para una agenda regional. CEPAL. Available at: https://www.cepal.org/es/publicaciones/44799-nudos-criticos-desarrollo-socialinclusivo-america-latina-caribe-antecedentes (Accessed: 03.01.2020).

CEPAL. 2014: Panorama Social de América Latina. Available: https://www.cepal.org/es/publicaciones/37626-panorama-social-america-latina-2014. (Accessed: 03.01.2020).

COADY, D. - GROSH, M. - HODDINOTT, J. 2004: Targeting of Transfers in Developing Countries: Review of Lessons and Experience. The World Bank. https://doi.org/10.1596/0-8213-5769-7

CONEVAL. 2014. Metodología para la medición multidimensional de la pobreza en México. FERES, J.C. - MANCERO, X. 2001: El método de las necesidades básicas insatisfechas (NBI) y sus aplicaciones en América Latina, Serie estudios estadísticos y prospectivos. Naciones Unidas, CEPAL, Div. de Estadística y Proyecciones Económicas, Santiago de Chile. 
GARCÍA, M. - MOORE, C.M.T. 2012: The Rise of Cash Transfer Programs in Sub-Saharan Africa, in: The Cash Dividend, Directions in Development - General. The World Bank, pp. 31-73. https://doi.org/10.1596/9780821388976_CH02

GUDYNAS, E. - ACOSTA, A. 2011: La renovación de la crítica al desarrollo y el buen vivir como alternativa. Utopía y praxis latinoamericana 16. núm. 53, pp. 71-83. Universidad del Zulia Maracaibo, Venezuela.

INEC. 2015: Índice de pobreza multidimensional: resultados generales Costa Rica. Available at:

https://www.inec.cr/sites/default/files/documentos/pobreza_y_presupuesto_de_hogares/p obreza/publicaciones/copublicipm-29102015.pdf. (Accessed: 03.01.2020).

INTERNATIONAL LABOUR OFFICE 1978. Employment, growth and basic needs: Presented at the Tripartite World Conference on Employment, Income Distribution and Social Progress, and the International Division of Labour (1976 : Geneva), International Labour Office.

KANBUR, R. - SUMNER, A. 2012: Poor Countries or Poor People? Development Assistance and the New Geography of Global Poverty. Journal of International Development 24, pp. 686-695. https://doi.org/10.1002/jid.2861

KAST, M. - MOLINA, S. 1975: Mapa de la extrema pobreza. Odeplan, Escuela de Economía PUC. Santiago de Chile Available at: http://www.desarrollosocialyfamilia.gob.cl/btca/txtcompleto/DIGITALIZADOS/ODEPL AN/O32Pm-1975-mapaextpobr.pdf. (Accessed: 03.01.2019).

KAZTMAN, R. 1989: La Heterogeneidad de la Pobreza. El Caso de Montevideo. Revista de la Cepal, pp. 141-152. Available at: http://hdl.handle.net/11362/11735 (Accessed: 03.01.2019)

KLUGMAN, J. 2010: Human development report 2010-20th anniversary edition. The real wealth of nations: pathways to human development 7. United Nations Development Programme.

MILANOVIC, B. 2016: Global inequality. Harvard University Press, Cambridge, Massachusetts.

MINISTERIO DE DESARROLLO SOCIAL - OPHI. 2018: Índice de Pobreza Multidimensional, IPM-Gt. Available at: https://mppn.org/wpcontent/uploads/2019/10/Guatemala-Report-IPM-gt_29jul19-v1.1.pdf. (Accessed: 03.01.2020). 
MINISTERIO DE DESARROLLO SOCIAL Y FAMILIA. 2019: Informe de Desarrollo Social Chile $2019 . \quad$ Available at: https://www.desarrollosocialyfamilia.gob.cl/storage/docs/Informe_de_Desarrollo_Social _2019.pdf. (Accessed: 03.01.2020).

MINISTERIO DE ECONOMÍA Y FINANZAS, M. DE D.S., INSTITUTO DE ESTADÍSTICA Y CENSO 2017: Índice de Pobreza Multidimensional de Panamá. Panamá: UNICEF. Available at: https://www.mides.gob.pa/wpcontent/uploads/2019/05/IPM-NNA.-Panama\%C4\%9B-2018-web.pdf. (Accessed: 03.01.2020).

NARAYAN, D. - PETEL, R. - SCHAFFT, K. - RADEMACHER, A. - KOCH-SCHULTE, S. 2000: Voices of the poor: Can anyone hear us? World Bank.

OPHI - UNDP. 2019: Global multidimensional poverty index 2019: illuminating inequalities. Available at: https://reliefweb.int/sites/reliefweb.int/files/resources/mpi_2019_publication.pdf. (Accessed: 03.01.2020).

ROBEYNS, I. 2005: Selecting Capabilities for Quality of Life Measurement. Soc Indic Res 74, pp. 191-215. https://doi.org/10.1007/s11205-005-6524-1

SANTOS, M.E. 2014: Measuring Multidimensional Poverty in Latin America: Previous Experience and the Way Forward. OPHI Working Paper No.66.

SANTOS, M.E. - VILLATORO, P. 2018: A Multidimensional Poverty Index for Latin America. Review of Income and Wealth 64, pp. 52-82.

SCGG-INE. 2016: Medición multidimensional de la pobreza Honduras. Tegucigalpa: Secretaría de Coordinación General de Gobierno y El Instituto Nacional de Estadística.

SECRETARÍA TÉCNICA Y DE PLANIFICACIÓN DE LA PRESIDENCIA, MINISTERIO DE ECONOMÍA A TRAVÉS DE LA DIRECCIÓN GENERAL DE ESTADÍSTICA Y CENSOS (eds.). 2015: Medición Multidimensional de la Pobreza El Salvador.

SEN, A. 2009: Capability: Reach and Limit, in: Debating Global Society: Reach and Limits of the Capability Approach. Fondazione Giangiacomo Feltrinelli, Milan, p. 16.

SEN, A. 1999: Development as Freedom. Oxford University Press, Oxford, New York, p. 37. STANTON, E.A. 2007: The Human Development Index: A History 37. WORKINGPAPER SERIES. Number 127. Gordon Hall. 
STIGLITZ, J.E. - SEN, A. - FITOUSSI, J. 2009: The Measurement of Economic Performance and Social Progress Revisited. The Measurement of Economic Performance and Social Progress Revisited. Commission on the Measurement of Economic Performance and Social Progress, Paris.

UN. 2015: Transforming our world: the 2030 Agenda for Sustainable Development:Sustainable Development Knowledge Platform [WWW Document]. Available at: https://sustainabledevelopment.un.org/post2015/transformingourworld (Accessed: 03.01.2019).

VICEPRESIDENCIA DE LA REPUBLICA DOMINICANA SIUBEN (Sistema Unico de Beneficiarios) 2020: Índice de Pobreza Multidimensional de la República Dominicana. WMR. 2020: World Migration Report 2020. International Organization for Migration, Geneva, Switzerland.

WORLD BANK. 2020: Poverty and Shared Prosperity 2020: Reversals of Fortune. The World Bank. Available at: https://openknowledge.worldbank.org/handle/10986/34496 License: CC BY 3.0 IGO. 


\section{Appendix}

Dimensions used in Unsatisfied Basic Needs Approaches and Multidimensional Poverty Measurements in Latin America

\begin{tabular}{|c|c|c|c|c|c|c|c|c|}
\hline & $\begin{array}{l}\text { IPM Global } \\
\text { PNUD/OPHI }\end{array}$ & ECLAC & Chile & Colombia & Costa Rica & $\begin{array}{l}\text { Dominican } \\
\text { Republic }\end{array}$ & Ecuador & EI Salvador \\
\hline $\begin{array}{l}\text { Dimensions in } \\
\text { UBN } \\
\text { measurements } \\
\text { since } 1980 \text { 's } \\
\text { until } 2000 \text { 's }\end{array}$ & & $\begin{array}{l}\text { recommendations } \\
\text { for the region: } \\
\text { type of housing } \\
\text { and its materials } \\
\text { overcrowding } \\
\text { availability of } \\
\text { water } \\
\text { access to toilet } \\
\text { school } \\
\text { attendance of } \\
\text { children } \\
\text { economic } \\
\text { capacity }\end{array}$ & $\begin{array}{l}\text { type of } \\
\text { housing } \\
\text { overcrowding } \\
\text { excrete } \\
\text { elimination } \\
\text { system } \\
\text { equipment }\end{array}$ & $\begin{array}{l}\text { materials of } \\
\text { housing } \\
\text { overcrowding } \\
\text { basic } \\
\text { services } \\
\text { education } \\
\text { economic } \\
\text { capacity }\end{array}$ & $\begin{array}{l}\text { access to } \\
\text { decent } \\
\text { housing } \\
\text { access to } \\
\text { healthy life } \\
\text { access to } \\
\text { knowledge } \\
\text { access to } \\
\text { services }\end{array}$ & $\begin{array}{l}\text { house with } \\
\text { dirt floor } \\
\text { access to } \\
\text { water service } \\
\text { access to } \\
\text { toilet } \\
\text { access to } \\
\text { electricity } \\
\text { overcrowding } \\
\text { adult with } \\
\text { semi-illiteracy }\end{array}$ & $\begin{array}{l}\text { materials of } \\
\text { housing } \\
\text { overcrowding } \\
\text { availability of } \\
\text { drinking } \\
\text { water } \\
\text { excrete } \\
\text { elimination } \\
\text { system } \\
\text { education } \\
\text { economic } \\
\text { capacity }\end{array}$ & $\begin{array}{l}\text { only income } \\
\text { measurement }\end{array}$ \\
\hline $\begin{array}{l}\text { Dimensions in } \\
\text { the new national } \\
\text { Multidimensional } \\
\text { Poverty } \\
\text { measurement }\end{array}$ & $\begin{array}{l}\text { health } \\
\text { education } \\
\text { living } \\
\text { standards }\end{array}$ & $\begin{array}{l}\text { type of housing } \\
\text { basic services } \\
\text { education } \\
\text { employment and } \\
\text { social protection } \\
\text { living standards } \\
\text { (including } \\
\text { income) }\end{array}$ & $\begin{array}{l}\text { education } \\
\text { health } \\
\text { work and } \\
\text { social } \\
\text { security } \\
\text { housing and } \\
\text { environment } \\
\text { networks and } \\
\text { social } \\
\text { cohesion }\end{array}$ & $\begin{array}{l}\text { household } \\
\text { education } \\
\text { conditions } \\
\text { childhood } \\
\text { and youth } \\
\text { conditions } \\
\text { employment } \\
\text { health } \\
\text { acces to } \\
\text { public utilities } \\
\text { and housing } \\
\text { conditions }\end{array}$ & $\begin{array}{l}\text { education } \\
\text { health } \\
\text { housing and } \\
\text { internet } \\
\text { access } \\
\text { employment } \\
\text { social } \\
\text { security }\end{array}$ & $\begin{array}{l}\text { health } \\
\text { education } \\
\text { and child } \\
\text { care } \\
\text { livelihood and } \\
\text { work } \\
\text { housing and } \\
\text { environment } \\
\text { digital divide } \\
\text { and } \\
\text { community }\end{array}$ & $\begin{array}{l}\text { education } \\
\text { work and } \\
\text { social } \\
\text { security } \\
\text { health, water } \\
\text { and nutrition } \\
\text { housing and } \\
\text { healthy } \\
\text { environment }\end{array}$ & $\begin{array}{l}\text { education } \\
\text { housing } \\
\text { conditions } \\
\text { work and } \\
\text { social } \\
\text { security } \\
\text { health, basic } \\
\text { services and } \\
\text { food security } \\
\text { quality of } \\
\text { environment }\end{array}$ \\
\hline poverty line & $30 \%$ & $25 \%$ & $22,50 \%$ & $33 \%$ & $20 \%$ & $33 \%$ & $33,30 \%$ & $35 \%$ \\
\hline
\end{tabular}

Sources: Edition of the author based on data of El método de las necesidades básicas insatisfechas (NBI) y susaplicaciones en América Latina, 2001, Informe de Desarrollo Social Chile 2019, Índice de pobreza multidimensional: resultados generales Costa Rica., 2015, Índice de Pobreza Multidimensional para Colombia, 2011, Medición de la Pobreza Multidimensional en Ecuador., Medición multidimensional de la pobreza Honduras, 2016, 2015, Medición Multidimensional de la Pobreza El Salvador, 2015, Índice de Pobreza Multidimensional, IPM-Gt., 2018, Metodología para la medición multidimensional de la pobreza en México, 2014, Índice de Pobreza Multidimensional de Panamá, 2017, Índice de Pobreza Multidimensional de la República Dominicana, 2020, Panorama Social de América Latina, 2014. 


\title{
Gender Equality as a sustainable development goal in the Maghreb? \\ Morocco, Tunisia and Algeria compared
}

\author{
Xénia Zsuzsanna SIPOS ${ }^{42}$
}

\begin{abstract}
The international political order witnessed the emergence of non-state actors from the 1970s which brought about an increased activity for women's rights representatives and civil societies and led to the organization of women's rights conferences. Among them, the Beijing Conference in 1995 is considered to be the most remarkable event in terms of women's empowerment. Gender mainstreaming became a significant strategy for decision-makers and achieving gender equality is displayed as one of the main goals of the 2030 Agenda for Sustainable Development. Embedded into the framework of transnationalism, the research analyses the direction of the relationship between non-state actors and decision-makers by the application of a matrix, while also taking into account the different historical, political and economic circumstances of Tunisia, Algeria and Morocco. Besides applying quantitative data related to the clarification of basic concepts (e.g. family code) the paper focuses on the implementation of the basic goals in favor of women empowerment by each country. In this regard, the research examines whether greater efforts made by the relevant governments were the result of a top-down pressure or significant steps had already existed before the 1980's. The analysis states that despite the implementation of significant reforms towards women's empowerment, the presence of traditional practices in these countries, namely in the countryside, is seen as a major constraint in front of achieving gender equality.
\end{abstract}

Keywords: gender equality, sustainable development, Maghreb feminism, non-state actors, transnationalism

\section{Introduction}

The gaining of independence from the French colonial power in Morocco, Tunisia, and Algeria between 1956 and 1962 brought about an increased capacity for women's rights organizations and activists which resulted in an active discourse on women's empowerment. The transformation of the international order starting from the 1980s had a great impact on the grassroots movements and thus also shaped the political direction of the decision-makers. As a result of this process, achieving gender equality became one of the 17 Sustainable Development Goals as part of the 2030 Agenda for Sustainable Development (UNITED NATIONS n.d.) and not only global, but regional formations also appeared, from which Collectif 95-Maghreb Égalité, the biggest network of feminist NGOs established in 1992 emerges (MAHFOUDH 2014). An important event regarding women's empowerment was the Beijing Conference organized in 1995 the outcome of which was the adoption of the Beijing Platform for Action that identified twelve areas (including equal conditions in the labour market, in education, access to healthcare as well as in decision-making) where significant steps must be made to eliminate gender inequality (UN WOMEN 2015). Although the growing

\footnotetext{
${ }^{42}$ Corvinus University of Budapest, Doctoral School of International Relations and Political Science, PhD Student, $\underline{x e n i a . s i p o s @ s t u d . u n i-c o r v i n u s . h u ~}$
} 
presence of non-state actors challenged the state-centric view, nobody can contest the fact that states still remain the most important players of the international political arena. The paper focuses on the analysis of the interaction between subnational actors and governments of the North African countries by evoking KEOHANE and NYE's concept of transnationalism and the results and impact of transnational interactions (NYE-KEOHANE 1971) on the respective governments.

In order to understand the creation of women's rights organizations in the French Maghreb, it is indispensable to note that in the analysed region the appearance of these formations can be traced back long before the processes of the 1980s and are strictly interlocked with the aforementioned countries' struggle for independence as well as their own political, historical, social and cultural characteristics. On the one hand, the international initiatives served as a dive for the coming into being of such notions as discrimination made on the basis of sex, violence against women or gender mainstreaming. On the other hand, the patriarchal system and the discriminatory family laws (BARSKA 2019) posed a serious obstacle before achieving gender equality, namely in Morocco and Algeria. In this regard, Tunisia followed a unique path in terms of women's rights that made it stand out from the two other countries also analysed in the paper. The North African Country's Western type modernization process relied primarily on the diversification of its economy and the enhancement of its human capital with a special focus on women's empowerment (BALIAMOUNE-LUTZ 2009). Above all, in 1956 Le Code du Statut Personnel (Personal Status Code, henceforward referred to as CSP) abolished polygamy, provided women the right to divorce and to child custody, and set a minimum age for marriage (CODE DU STATUT PERSONNEL 2012). In 1958 Bourguiba introduced compulsory education for young women and people living in rural areas (CHABCHOUB 2014).

Starting from the period of decolonization and touching upon the changes brought by the processes of the Arab Spring the paper aims to provide an overview of the situation of women in each country concerned by the analysis. Moreover, with a special focus on the rigid social structures and traditions (e.g. family codes) of Morocco, Algeria and Tunisia as constraints in achieving gender equality the essay examines whether positive initiatives regarding women's empowerment were the outcome of the regional and global efforts of the " $80 \mathrm{~s}$ or ' 90 s or previous initiatives had already been taken by the respective governments. 


\section{Transnationalism and its impact on decision-makers}

In order to be able to analyse to what extent global and regional efforts contributed to the formation of women's rights movements, thus influencing the activities/initiatives of the decision-makers in the three analysed Maghreb countries, the paper applies the work of Joseph S. NYE and Robert O. KEOHANE entitled Transnational Relations and World Politics: An Introduction issued in 1971. The aforementioned work is crucially important from the point that both experts of international relations shed light on the changes in the processes of the international political arena starting from the 1970's and 1980's and emphasized the phenomenon of complex interdependence produced by the appearance of new political actors, i.e. sub-state actors and their growing influence on decision-makers.

In his book published in 1994, MILLER pointed out the more complex features of the international political processes and emphasized that the traditional state-centric order was replaced by a transnational system as a result of the increasing level of political, economic and cultural transactions (MILLER 1994). Thus, the complexity of the new political order also evoked the need to solve and set up a discourse on previously marginalized, but crucially important subjects (including women's empowerment, too) the resolution of which required active contribution from various non-governmental organizations. With regard to the new political actors of the international relations, it is also indispensable to distinguish between intergovernmental organizations (IGOs) and transnational or international non-governmental organizations (NGOs). In this regard, only the second category brought into being by sub-state actors can be called transnational as the last category was created to delegate on them those tasks that governments were unable to cope with. While on the one hand nobody can deny that the traditional political order still remains state-centric, on the order hand we cannot contest the fact that through their mobilization and monitoring, activists and regional organizations also exert a significant influence in certain contexts not only on public opinion, but on the measures of governments, too. The question that divides experts of international relations lies in the real effectiveness of sub-state actors and what impact they have on their respective governments (ATAMAN 2003).

NYE and KEOHANE also emphasized that states are not the only actors of world politics, but in certain cases non-governmental actors have a greater impact on international processes than states themselves. In their aforementioned work their research mainly focused on the possible impact of the loss of control on governments, whether state-centric analysis can still be maintained in IR research, the beneficiaries of the new political order and the challenges 
and future of international organizations as a result of the process of complex interdependence. Concerning the difference between interstate and transnational activities similarly to MILLER's statement NYE and KEOHANE claimed that contrary to interstate activities the main characteristics of transnational interactions is that they involve sub-state actors as well. With regard to the direct role non-governmental organizations play in influencing the events of the international political arena NYE and KEOHANE highlighted that in this sense sub-state entities bypass their governments (NYE - KEOHANE 1971). The paper focuses on women's empowerment on the international level to draw conclusions about the process of the adoption of the goals of the Beijing Platform for Action in each analysed country. When approaching the question of gender mainstreaming it is indispensable to underline that gender equality guaranteed on the political, economic, and social levels as also determined by the Beijing Platform for Action (UNITED NATIONS 2002) could not be realized without a bottom-up approach. In absence of such efforts, measures introduced by decision-makers could result in the alienation of the concerned group (MOSER 2005).

The paper aims to analyse the evolution of women's rights in the Maghreb through the five effects of transnationalism on state behaviour as stated by NYE and KEOHANE. These include the following changes: changes in attitude, the emergence of international pluralism, limitations on states to manoeuvre as a result of the alteration of the traditional state-centric order, an increased ability to influence other governments and a more significant role of substate actors that in some cases tend to overwrite the priorities and policies of governments (NYE - KEOHANE 1971). Besides examining the effects of transnationalism in Morocco, Algeria, and Tunisia and analysing whether progresses made on the policy of gender and development demonstrates a top-down or bottom-up approach, the paper also incorporates the main goals of the Beijing Platform for Action to have a look at the performance each state has made in terms of achieving gender equality. In order to be able to provide detailed findings the paper discusses those twelve areas that representatives of governments and NGOs found crucially important on the Fourth World Conference on Women in Beijing.

\section{Beijing Platform for Action: gender equality for a sustainable world}

The end of the 1970s - also identified in the previous chapter as the period of the growing influence of sub-state actors on the processes of the international political arena - came to fruition in 1979 with the adoption of CEDAW (Convention on the Elimination of All Forms of Discrimination against Women) (INTER-PARLIAMENTARY UNIONa n.d.). The Convention not only gives a clear definition about discrimination based on gender but is also 
considered as a guide for governments to provide gender equality. Also referred to as the international bill of rights for women, the recommendations of CEDAW were carried on during the subsequent follow-up conferences, from which the Beijing conference in 1995 stands out (UNITED NATIONS ENTITY n.d.). Besides elaborating the notion of gender mainstreaming as a main strategy for governments to achieve equality between women and men the twelve areas where greater efforts must be made to eliminate inequalities include women and poverty, education and training for women, women and health, violence against women, women and armed conflict, women and the economy, women in power and decision-making, institutional mechanisms for the advancement of women, human rights of women, women and the media, women and environment and the girl child (UN WOMEN 2015). Concerning the evolution of achieving gender equality as also being included in the global 17 Sustainable Development Goals adopted by UN member states in 2015 (UNITED NATIONS n.d.), the report issued by UN Women on the occasion of the $20^{\text {th }}$ anniversary of the Beijing Conference shed light on the deterioration of women's rights in certain areas. The report stated that while greater opportunities in education and more active participation in the labour force were available for the weaker sex, measures proved to be insufficient in other areas and women still face discrimination in terms of equal rights. From the point of the major focus of the analysis it is also indispensable to underline that the report names ongoing economic and financial crisis, volatile food and energy prices and climate change as factors responsible for undermining the assurance of equal opportunities for both sexes (UN WOMEN 2015). Regarding the Maghreb countries, the political, historical and cultural characteristics that also serve as constraints in front of achieving gender equality can also be listed among the aforementioned factors. Moreover, the evolution of women's rights in the Maghreb cannot be separated from the insecurities (e. g. civil war in Algeria in the 1990's, the breakout of the Arab Spring at the end of 2010) and the dichotomy of the adherence to the Western model of development on the one hand, and to the traditional norms on the other hand.

When approaching the topic of sustainability from the aspect of women's empowerment it must be highlighted that achieving gender equality is a must to a just and sustainable development both in the economic, social and environmental field. Among them, it is mainly the social pillar where significant efforts (e.g. equal chances in the labour market) should be done in order to ensure sustainability (STEVENS 2010). Another aspect of the topic of sustainability would name value change, political economy, adaptive economics and planning intervention as crucial perspectives to achieving equality between women and men. It is also indispensable to underline that while changes in ideas play an important role in shaping 
attitudes regarding gender equality, no significant results can take place without pressures coming from the society, economy or the environment, which clearly underline that sustainable development is rather considered to be a political term (LEE-SMITH - TRUJILLO 1992).

With reference to the main goals of the Beijing Platform for Action, inequalities in the labour market are identified as one of the main obstacles in front of achieving gender equality (CORNWALL - EDWARDS 2015). Moreover, the lack of employment opportunities is in close relation with other areas of focus of the Platform where further efforts must be made, including the eradication of poverty or the protection of equal rights for women. According to the Beijing Platform for Action, every government is responsible for ensuring appropriate working conditions for women and putting an end to discrimination. The report issued on the occasion of the $20^{\text {th }}$ anniversary of the adoption of the Platform to revise the major steps that have been taken so far stated that the gender gap was globally reduced from $28 \%$ to $26 \%$. However, regional disparities and the overrepresentation of women in low-paid jobs still remain crucial problems that require solution. The Beijing Platform for Action identified the Middle East and North Africa (MENA) as being the region affected the most by inequalities in terms of participation in the labour force (56\%), and the situation in the MENA countries has not changed until 2012 when this ratio was 53\% (UN WOMEN 2015).

Concerning the objective of the Platform to ensure wider participation for women in decision-making, the report found that while by 2014 the percentage of women in the parliament had already demonstrated a steady increase (23\% globally contrary to $12 \%$ in 1995 ), women are still underrepresented when it comes to high government positions (e.g. speakers of parliament and ministers). From the point of the analysis, it must be highlighted that in 1995 the percentage of women sitting in the national parliaments was the lowest one in the MENA countries (only 4\%) compared with other regions. By 2005 this percentage doubled, but except for South Asia the region of the Middle East and North Africa was still below the global average. While by 2014 gender equality in the field of decision-making in the MENA region further improved (17\% of the representatives of the parliament were women) (UN WOMEN 2015), women's participation in the political arena has not achieved the necessary percentage determined by the United Nations Convention on the Elimination of All Forms of Discrimination against Women, CEDAW (30\%) (INTER-PARLIAMENTARY UNIONa n.d.). When it comes to the significant increase in women's political participation we cannot neglect the events of 2011 (widely known as the "Arab Spring") which also served as a catalyst in terms of women's empowerment and thus brought about a widespread discourse on women's rights. It is also indispensable to underline that the evolution of gender mainstreaming shows 
differences even within the same geographical location, not to mention the extension of the region of North Africa to the Middle East. Therefore, it must be underlined that generalizations cannot be made even within the same cultural scope. According to the up-to-date ranking of IPU (as of 1 January, 2021), with 57 female representatives out of the 217 places in the National Constituent Assembly (NCA), which means a 26.3\% female representation, Tunisia anticipates Algeria and Morocco where women make up $26 \%$ and $20.5 \%$ of the decision-makers in the national parliament (INTER-PARLIAMENTARY UNION $b$ n.d.). Within the framework of the Beijing Platform for Action, states engaged in assuring constitutional and legal reforms and the adoption of quotas both on the national as well as on the international level together with the involvement of women's organizations.

With regard to the third main focus of the Beijing Platform for Action, i.e. ensuring the possibility for women to control their lives, the report issued on the occasion of the $20^{\text {th }}$ anniversary of the Action stated that despite of the implementation of significant reforms to improve the marginal position of women discrimination still exists in certain areas, namely in the area of family law that is also relevant from the point of the current analysis. The report also sheds light on the reservations of some states to the CEDAW and on the lack of its universal ratification and implementation as being one of the constraints in front of achieving gender equality. For providing equal rights for both sexes, constitutional and legislative provisions must be removed. These measures include the reform of family laws, nationality laws and laws related to inheritance (UN WOMEN 2015). The comparison between Morocco, Algeria and Tunisia examines the major steps governments of these countries have taken to eliminate discriminatory measures in family or personal status laws. Moreover, the essay also touches upon whether the analysed Maghreb counties have made some reservations to CEDAW and if this is the case whether some developments have been made to lift these reservations.

In evaluating the major goals towards achieving gender equality as also determined in the Beijing Platform for Action, the paper highlighted the existence of gap between men and women in terms of possibilities offered by the labour market. Participation in decision-making was also identified as a crucially important area where further efforts must be made, namely in Morocco where the participation of women in the national parliament is relatively low. Finally, the presence of restrictive measures embedded in the national laws of each country is also seen as a field which requires greater attention, namely the reform of family laws. In the framework of the implementation of the major goals of the Beijing Platform for Action the next chapter compares the practices of each Maghreb country in terms of ensuring equal gender rights. The 
analysis of the evolution of women's empowerment in this region will contribute to understanding the framework of the paper, i.e. the direction of the gender policy in Morocco, Algeria, and Tunisia and the long-term consequences of the emergence of sub national actors of decision-makers.

\section{The impact of the implementation of the Beijing Platform for Action on the evolution of women's rights in Morocco, Algeria, and Tunisia: towards a gender-equal region?}

As it has already been mentioned above, the analysis of women's rights in the Maghreb countries cannot be separated from the particular political, economic, cultural, social, but mainly historical processes these states have gone through. On the one hand, the reforms made in these countries focused on the modification of the fundamental set of laws that regulate the status of women in everyday life, i.e. the family code, which as a consequence resulted in the extension of their rights and thus in a greater access to education and political representation, notably in Tunisia and Morocco. On the other hand, the presence of some social practices is seen as a serious burden in front of achieving gender equality (KIMANI 2008).

\subsection{The Tunisian model of ensuring gender equality}

When it comes to the analysis of the evolution of women's empowerment in the Maghreb, there is a widespread agreement among members of the international community that Tunisia stands out from other Muslim countries in terms of women's rights. In Tunisia, the centralization of power brought about a strong political leadership with President Bourguiba taking this role in 1957. Due to the poor indicators of human development ${ }^{43}$, Bourguiba realized that a modernization process was inevitable to set the country on the path of development. The Bourguibist state-building program meant the adoption of a Western model of development and therefore a reduced role of women's rights movements (SADIQI 2008).

The most significant measure of Bourguiba was the adoption of Le Code du Statut Personnel (Personal Status Code, henceforward referred to as CSP) in 1956 that abolished polygamy, provided women the right to divorce and to child custody, and set a minimum age for marriage (CODE DU STATUT PERSONNEL 2012). In 1958, Bourguiba introduced compulsory education for young women and people living in rural areas (CHABCHOUB

\footnotetext{
${ }^{43}$ In 1956 the literacy rate only reached $15 \%$ and only one child in thirty received a high-school education (TESSLER-KEPPEL 1976).
} 
2014). It was due to the introduction of family planning in the 1960s and the legalization of abortion in 1973 (JOMIER 2011) that Tunisia anticipated France, where it was only legalized in 1975. Bourguiba's successor, President Ben Ali continued the promotion of the image of modern Tunisia from his coming to power in 1987 (ENNAJI 2020), which also meant the pursuance of state-controlled feminism under which only those women's NGOs could operate that enjoyed the government's approval. (The two most dominant women's rights organizations that also posed a challenge to the government were the Union Nationale de la Femme Tunisienne (UNFT) (UNFT n.d.) founded in 1956 and the Association Tunisienne des Femmes Democrates (ATFD)) (ATFD n.d.). As a result of the repressive measures of President Bourguiba and Ben Ali on the freedom of associations and the freedom of expression, the postArab Spring era opened the way for the aforementioned organizations to freely embrace previously marginalized topics and thus a widespread discourse started on topics like equal inheritance. Concerning the third focus of the Beijing Platform for Action, i.e. the field of human rights and the elimination of discrimination, it must be underlined that Tunisia ratified the CEDAW in 1985, but with some reservations that were only lifted in 2014. In 2002 the citizenship law was amended that enabled women married to foreign nationals to pass their citizenship to their children (ENNAJI 2020). Evoking women's participation in decisionmaking is also marked as a key area where further efforts must be made to foster the assurance of equal rights to both sexes. In this regard it must be mentioned that according to the October 2019 ranking of the IPU, with 78 female representatives out of the 217 places in the National Constituent Assembly (NCA), meaning a 35.9\% representation, Tunisia occupied the $31^{\text {st }}$ place worldwide and ranked the highest among other Arab countries. This percentage was only $26.3 \%$ (57 female representatives) according to the latest ranking of 1 January 2021, which made Tunisia only the $4^{\text {th }}$ Arab country in the ranking (occupying the $77^{\text {th }}$ place worldwide) behind the UAE, Egypt and Iraq (INTER-PARLIAMENTARY UNION $b$ n.d.). While significant steps have been made by the previous leaders of the country to ensure women's empowerment, the national strategy for the period of 2017-2020 elaborated by the Tunisian Ministry of Woman, Family and Childhood to improve the conditions of women and girls living in the marginalized regions clearly demonstrates the deficiencies regarding women's equal access to the labour market. According to the Tunisian Bureau of Statistics, in 2014 only $20 \%$ of women living in rural areas disposed of a decent job and in some regions the unemployment rate surpassed $40 \%$. In the most marginalized regions $61 \%$ of women worked in the most vulnerable agricultural sector among whom only $12 \%$ had access to medical and social services (MINISTERE DE LA FEMME, DE LA FERTILITE ET DE L'ENFANCE 
n.d.). These statistical data shed light on the fact that despite of the great achievements of decision-makers and the pressures coming from sub-state actors namely following the Arab Spring, Tunisia has still a long way to satisfy the economic goals stated in the Beijing Platform for Action.

\subsection{Women's rights activism in Algeria}

Compared with Tunisia, the initial position of women's rights activists in Algeria differed from its eastern neighbour as the significant number of women (more than 10000 ) involved in the country's eight years' bloody war of independence contributed to the boosting of women's position in the society (PEPICELLI 2017). Following the country's independence in 1962 women were given the right to vote. However, despite these bottom-up initiatives, the question of gender equality was treated in the 1960's and 1970's as a secondary topic since the statebuilding process focused rather on development objectives. To better understand the differences between Algeria and Tunisia, it is of crucial importance to see that instead of a homogeneous society Algeria is a more patriarchal society made up of conservative tribal structures each of them following their own traditions (ENNAJI 2020). Contrary to Tunisia, the centralization of power and the monopolization of private domestic sphere based on the Western model of development did not take place in Algeria that had serious impacts on the evolution of women's rights in the country. As a result of the conservation of traditional social practices and the marginalization of the question of gender equality, Algeria was the last country among its neighbors that enacted a family law in 1984 and thus further consolidated the subordinated position of women. The disadvantageous position of Algeria is also demonstrated by the fact that the amendment of the family code only took place in 2005 following the pressures coming from the events of the 1990's and thus a more active role of women's rights organizations from 2005. While the amendment of the family law provided greater rights for women regarding divorce and marriage and they could also pass their citizenship to their children, the constitutional reform of 2008 which recognized women's political participation are proves that in Algeria a significant fallback regarding women's empowerment does exist compared with Tunisia or Morocco. The contradiction between the constitutional guarantees and the constraints of the family code is seen as a major burden in front of achieving gender equality. With regard to the elimination of discrimination against women as one of the main goals mentioned in the Beijing Platform for Action, it must be underlined that compared with Tunisia and Morocco Algeria only ratified the CEDAW in 1996 and up until today no restrictions were lifted (ENNAJI 2020). Concerning the political 
participation of women, Algerian women make up 26\% of the lower house and $5.7 \%$ of the upper chamber of the parliament according to the up-to-date ranking of the IPU. While public opinion is quite suspicious about women holding high-level government positions, in the field of judiciary Algeria did far better than Tunisia or Morocco. According to an article dating back to 2008 , women made up half of the judges in the country whereas this percentage was only $27 \%$ in Tunisia (KIMANI 2008). While access to up-to-date and reliable statistical data regarding women's participation in the labour market faces serious challenges in the Maghreb, and more particularly in Algeria, according to the latest statistics of the Algerian National Statistical Office available from May 2019 the percentage of occupation of the female labour force was only $17.3 \%$ compared with $66.8 \%$ among men. Concerning the total unemployment rate among men and women between the period of 2009 and 2019 unemployment among women was more than two times higher than that of men (20.4\% compared with $9.1 \%)$, the highest one after 2017 (ONS n.d.). These data clearly show that while the country's labour law provides equal access for women to the labour market, the duty of obedience clause of the traditional family law might pose serious obstacles in front of women's equal economic participation.

\subsection{The evolution of women's rights in Morocco}

Contrary to Tunisia or even Algeria, the situation of women in Morocco demonstrated an inferior position due to the presence of traditional social practices. This was further consolidated in the family law of 1957, also called as Mudawwana. However, the growing activities of various women's rights NGOs (from which Association Démocratique des Femmes, ADFM and the Union de l'Action Feminine, UAF emerge) starting from the 1960's and their significant influence on decision makers distinguish Morocco from the two other Maghreb countries involved in the analysis. In Morocco, both changes in the country's leadership in 1999 (King Hassan II was followed by his son, King Mohamed VI) and the regularization of the operation of non-governmental organizations (foreign financial support to these formations was allowed) established a favourable environment for sub-state actors to successfully propagate their demands. As a result of an active role of women's rights organizations, a new Mudawwana was enacted in 2004 which significantly improved the conditions of Moroccan women, though could not be considered as progressive as the CSP of Tunisia was in 1956 (e. g. polygamy was not abolished). On one hand, from the point of view of the Beijing Platform for Action, Morocco ratified the CEDAW in 1993 and as a pressure of women's rights organizations lifted its reservations in 2011. Moreover, it also revised the work 
and penal code in 2003 and women could freely practice trade activity from 1995. However, on the other hand women could only transfer their citizenship to their children from 2007 (ENNAJI 2020). Concerning women's participation in decision-making, as it has already been mentioned, out of the three countries analysed in this paper the representation of women in the national parliament was the weakest one in Morocco (women occupied only $20.5 \%$ of the lower house and $11.7 \%$ of the upper chamber) according to the latest ranking of IPU. With regard to women's participation in the labour market according to the statistical data of the High Commission of Planing (Haut Commisariat au Plan) (HCP n.d.) between the period of 1999 and 2020, gender inequalities in terms of unemployment started to rise from 2017 (8.8\% vs. $14.7 \%$ ). However, as it has been previously mentioned, these data still remain low compared with Algeria where unemployment between women are more than two times higher than that of men (a summary of the results can be seen in Table 2).

\section{Conclusion}

The paper aimed to shed light on the growing significance of non-state actors starting from the end of the 1970s and their role in shaping the attitudes of decision-makers. From the point of view of sustainability, the analysis reinforced the fact that gender equality is clearly a political term, therefore the necessary measures taken in this context to ensure equal chances to both sexes and thus contribute to economic growth and increase social conditions strictly depend on the policies of decision-makers (OECD 2008). The main focus of the analysis was to see to which extent these sub-state actors limited the space for states to manoeuvre through the main findings of Nye and Keohane. The paper reinforced the fact that despite of a complex interdependence of the international political order, states still remain the most important actors of international processes. The realignment of the previous political order opened the way for different NGOs to introduce such marginalized topics like gender inequalities to decisionmakers and thus foster and international cooperation in this sense. Embedded into an international framework of women's rights regime, the analysis compared countries of the same region. The topic is quite actual since the events of 2011 triggered a widespread debate on achieving gender equality in the Maghreb as a result of which positive changes have already taken place in Morocco and Tunisia (e.g. lifting the reservations made to CEDAW and ensuring higher percentage of seats for women in national parliaments). In fact, the results of the paper proved that despite the existence of similarities, the evolution of women's rights in Morocco, Algeria, and Tunisia is strictly linked to the particular political, social, cultural, economic and 
even historical characteristics of each country. Taking into consideration the $25^{\text {th }}$ anniversary of the Beijing Conference and the adoption of its Action Plan, the comparison in the aforementioned countries mainly focused on those areas where further efforts must be made by states to ensure women's empowerment (equal participation in the labour market, in decision-making and a greater commitment to the reform of restrictive laws). The analysis also dealt with the question of the direction of the evolution of women's rights in the Maghreb countries (bottom-up vs. top-down approach). In this regard, the paper involved the work of Joseph NYE and Robert KEOHANE on transnationalism to examine to what extent sub-state actors influenced the attitudes of decision-makers towards the question of gender equality. In Tunisia, which is considered to be the most progressive Arab country in terms of women's rights, the paper stated that the achievements were due to the presence of a strong leader (President Bourguiba) who set the country on the path of a Western-type modernization following its independence (this top-down approach is also known as state feminism). Therefore, the processes at the end of the 1970's had only limited impact on the activities of sub-state actors and their role became vital just following the events of the Arab Spring. Contrary to Tunisia, in Algeria the evolution of women's rights must be seen from a bottomup approach which is linked to the history of the country, ie the consequences of the bloody war of independence between 1954 and 1962 in which women played a crucial role. While the initial positions of women were rather favourable, unlike in Tunisia women's empowerment only occupied a marginal position in the country's state-building process. Therefore, in Algeria the amendment of the family code in 2005 was the result of the pressure of women's rights organizations on the state, indirectly derived from the events of the 1990's. Finally, in Morocco the proliferation of women's rights organizations from the 1990's was not only due to the country's favourable political environment, but to the indirect effects of the international efforts of women's rights organizations towards the support for realizing gender equality. 


\begin{tabular}{|c|c|c|c|}
\hline \multirow[t]{2}{*}{ ASPECTS OF THE ANYALYSIS } & \multicolumn{3}{|c|}{ ANALYSED COUNTRIES } \\
\hline & TUNISIA & ALGERIA & MOROCCO \\
\hline $\begin{array}{l}\text { Approach to the question of } \\
\text { gender equality }\end{array}$ & $\begin{array}{l}\text { TOP-DOWN approach (state- } \\
\text { feminism) }\end{array}$ & $\begin{array}{l}\text { BOTTOM-UP approach } \\
\text { (women's significant role in the } \\
\text { 8-years long bloody civil war } \rightarrow \\
\text { outstanding position for } \\
\text { women) }\end{array}$ & $\begin{array}{l}\text { BOTTOM-UP approach from the 1990's } \\
\text { (favorable political environment for } \\
\text { women's rights NGOs), but also an } \\
\text { institutional supremacy of the monarchy in } \\
\text { the political sphere that to some extent } \\
\text { can be regarded as a constraint in front of } \\
\text { realizing gender equality }\end{array}$ \\
\hline Political arena & $\begin{array}{l}\text { Centralization of power (state- } \\
\text { building process based on the } \\
\text { Western model of } \\
\text { development) }\end{array}$ & $\begin{array}{l}\text { Tribal structure, centralization } \\
\text { of power was a gradual } \\
\text { process (gender equality as a } \\
\text { marginal question in the state- } \\
\text { building process) }\end{array}$ & $\begin{array}{l}\text { Supremacy of the monarchy } \rightarrow \\
\text { centralization }\end{array}$ \\
\hline $\begin{array}{l}\text { Women's participation in the } \\
\text { labour market }\end{array}$ & $\begin{array}{l}\text { Fault-line between the northern } \\
\text { vs. southern regions (rural } \\
\text { areas: participation in the } \\
\text { labour market was only } 20 \% \text {, } \\
\text { unemployment rate was } 40 \% \text { ) }\end{array}$ & $\begin{array}{l}\text { Significant differences between } \\
\text { men and women (percentage } \\
\text { of occupation of the female } \\
\text { labour force was only } 17.3 \% \\
\text { vs. } 66.8 \% \text { at men; in } 2019 \\
\text { unemployment rate was more } \\
\text { than } 2 \text { times higher than that of } \\
\text { men) }\end{array}$ & $\begin{array}{l}\text { From } 2017 \text { gender gap is rising in the } \\
\text { labour market (unemployment rate of men: } \\
8.8 \% \text { vs. unemployment rate of women: } \\
14.7 \% \text { ). }\end{array}$ \\
\hline $\begin{array}{l}\text { Women's participation in } \\
\text { decision-making (according to } \\
\text { IPU'S ranking as of } 1 \text { January } \\
\text { 2021) }\end{array}$ & $\begin{array}{l}\text { The percentage of women } \\
\text { sitting I the national parliament: } \\
26.3 \%\end{array}$ & $\begin{array}{l}\text { Women make up } 26 \% \text { of the } \\
\text { lower house and } 5.7 \% \text { of the } \\
\text { upper chamber }\end{array}$ & $\begin{array}{l}\text { Women occupy only } 20.5 \% \text { of the lower } \\
\text { house and } 11.7 \% \text { of the upper chamber }\end{array}$ \\
\hline Legal background & $\begin{array}{l}\text { 1956: Personal Status Code } \\
(\mathrm{CSP}) \rightarrow \text { considered to be the } \\
\text { most progressive family law in } \\
\text { the Arab world; 1985: } \\
\text { ratification of CEDAW (2014: } \\
\text { lifting its reservations); 2002: } \\
\text { amendment of the citizenship } \\
\text { law }\end{array}$ & $\begin{array}{l}\text { 1984: enactment of the } \\
\text { Algerian family law } \\
\text { (subordinated position of } \\
\text { women) } \rightarrow \text { 2005: amendment } \\
\text { of the family law (transfer of the } \\
\text { citizenship of the mother to the } \\
\text { children) as a result of the } \\
\text { pressure of women's rights } \\
\text { NGOs; } 1996 \text { : ratification of the } \\
\text { CEDAW (no reservations were } \\
\text { lifted); } 2008 \text { : constitutional } \\
\text { reform } \rightarrow \text { recognized women's } \\
\text { political participation }\end{array}$ & $\begin{array}{l}\text { 1957: family law (subordinated position of } \\
\text { women) } \rightarrow \text { 2004: new family law } \\
\text { (mudawwana) was enacted as a result of } \\
\text { women's rights NGOs pressure; 1993: } \\
\text { ratification of the CEDAW (2011: lifting its } \\
\text { reservations); 1995: women could practice } \\
\text { trade activity; 2003: revision of the work } \\
\text { and penal code; 2007: transfer of the } \\
\text { citizenship of the mother to the children }\end{array}$ \\
\hline
\end{tabular}

Table 2: The evolution of women's rights in Morocco, Algeria and Tunisia Source: Edited by SIPOS Xénia based on ENNAJI 2020 


\section{References}

ATAMAN, M. 2003: The Impact of Non-State Actors on World Politics: A Challenge to Nation-States. Alternatives: Turkish Journal of International Relations 1: pp. 42-66.

ATFD: ASSOCIATION TUNISIENNE DES FEMMES DEMOCRATES (Tunisian Association of Democratic Women) (N.D.) Available at: https://www.cncdh.fr/fr/ong/association-tunisienne-des-femmes-democrates (Retrieved on 5 March 2021)

BALIAMOUNE-LUTZ, M. 2009: Tunisia's Development Experience: A Success Story? United Nations University. World Institute for Development Economics Research 32. Available at: https://www.wider.unu.edu/publication/tunisias-development-experience (Retrieved on 23 February 2021)

BARSKA, A. 2019: The evolution of the emancipation movement of Women in the Maghreb. Rocznik Orientalistyczny 1: pp. 143-152.

CHABCHOUB, A. 2014: Bourguiba et Moi. Dubai, Al Manhal.

CODE DU STATUT PERSONNEL 2012 : Imprimerie Officielle de la République Tunisienne Publications de l'Imprimerie Officielle de la République Tunisienne 2012. (Issued on 28 December 1956, with the latest modifications taking place on 26 July 2010). Available at: https://www.ilo.org/dyn/natlex/natlex4.detail?p_lang=fr\&p_isn=73374\&p_count=96182 $\underline{\& p \_c l a s s i f i c a t i o n}=01.03 \& p \_$classcount $=1024$ (Retrieved on 22 February 2021)

CORNWALL, A. - EDWARDS, J. 2015: Introduction: Beijing+20 - Where now for Gender Equality? IDS Bulletin, Institute of Development Studies 4: pp. 1-8.

ENNAJI, M. 2020: Women's Activism in North Africa: A Historical and Socio-Political Approach. In: DARHOUR, H. - DAHLERUP, D. 2020: Double-Edged Politics on Women's Rights in the MENA Region. London, Palgrave Macmillan.

HCP: HAUT COMISSARIAT AU PLAN (High Commission of Planning) (N.D.) Available at: www.hcp.ma (Retrieved on 6 March 2021)

INTER-PARLIAMENTARY UNIONa. (N.D.) Handbook for Parliamentarians. "The Convention on the Elimination of All Forms of Discrimination against Women and its Optional Protocol”. Available at: https://www.ipu.org/resources/publications/handbooks/2016-07/handbookparliamentarians-convention-elimination-all-forms-discrimination-against-women-andits-optional (Retrieved on 27 February 2021) 
INTER-PARLIAMENTARY UNIONb (N.D.) Monthly ranking of women in national parliaments. Available at: https://data.ipu.org/women-ranking?month=1\&year=2021 (Retrieved on 3 March, 2021)

JOMIER, A. 2011: Secularism and State Feminism: Tunisia's Smoke and Mirrors. Books and Ideas. Available at: https://booksandideas.net/Secularism-and-State-Feminism.html (Retrieved on 24 February 2021)

KIMANI, M. 2008: Women in North Africa secure more rights.

Available at: https://www.un.org/africarenewal/magazine/july-2008/women-north-africasecure-more-rights (Retrieved on 1 March 2021)

LEE-SMITH, D. -TRUJILLO, C. H. 1992: The struggle to legitimize subsistence: women and sustainable development. Environment and Urbanization 4, pp. 77-84.

MAHFOUDH, D. 2014 Le Collectif Maghreb-Égalité 95: Pour un Mouvement Féministe Maghrébine. Éditions Antipodes 33, pp. 132-135.

MILLER, L.H. 1994: Global Order: Values and Power in International Politics. Boulder, CO: Westview Press.

MINISTERE DE LA FEMME, DE LA FERTILITE ET DE L'ENFANCE (N.D.) “Stratégie nationale pour l'autonomisation économique et sociale des femmes et des filles rural, 2017-2020". Available at: http://www.femmes.gov.tn/wpcontent/uploads/2017/07/Presentation_Strategie_FR_2017-2020.pdf (Retrieved on 5 March 2021)

MOSER, C. - MOSER, A. 2005: Gender Mainstreaming Since Beijing: A Review of Success and Limitations in International Institutions. Gender and Development 2: pp. 11-22.

NYE, J.S. - KEOHANE, R.O. 1971: Transnational Relations and World Politics: An Introduction. Cambridge University Press 3: pp. 329-349.

OECD 2008: Gender and Sustainable Development. Maximising the Economic, Social and Environmental Role of Women. Available at: https://www.oecd.org/social/40881538.pdf (Retrieved on 14 May 2021).

ONS: OFFICE NATIONAL DES STATISTIQUES (National Statistical Office) (N.D.) Available at: http://www.ons.dz/ (Retrieved on 6 March 2021)

PEPICELLI, R. 2017: Rethinking Gender in Arab Nationalism: Women and the Politics of Modernity in the Making of Nation-States. Cases from Egypt, Tunisia and Algeria. Oriente Moderno. 1: pp. 201-2019.

SADIQI, F. 2008: Facing Challenges and Pioneering Feminist and Gender Studies: Women in Post-colonial and Today’s Maghrib. African and Asian Studies 7: pp. 447-470. 
STEVENS, C. 2010: Are Women the Key to Sustainable Development? The Frederick S. Pardee Center for the Study of the Longer-Range Future, Boston University. Available at: https://www.bu.edu/pardee/files/2010/04/UNsdkp003fsingle.pdf (Retrieved on 14 May 2021).

TESSLER, M. A. - KEPPEL, M. E. 1976: Political Generations. In: STONE, R. A. SIMMONS, J. 1976: Change in Tunisia. Studies in the Social Sciences. Albany: State University of New York Press.

UNFT: UNION NATIONALE DE LA FEMME TUNISIENNE (National Union of Tunisian Women) (N.D.) Available at:

https://jamaity.org/association/union-nationale-de-la-femme-tunisienne/ (Retrieved on 5 March 2021)

UNITED NATIONS ENTITY FOR GENDER EQUALITY AND THE EMPOWERMENT $\begin{array}{lll}\text { OF WOMEN } & \text { (N.D.) at: }\end{array}$ https://www.un.org/womenwatch/daw/beijing/index.html (Retrieved on 27 February 2021)

UNITED NATIONS 2002: Gender Mainstreaming. An Overview. Available at: https://www.un.org/womenwatch/osagi/pdf/e65237.pdf (Retrieved on 25 February 2021) UNITED NATIONS (N.D.) The Sustainable Development Agenda. Available at: https://www.un.org/sustainabledevelopment/development-agenda/ (Retrieved on 21 February 2021)

UN WOMEN 2015: Summary Report: The Beijing Declaration and Platform for Action turns 20: New York. Available at: https://www.unwomen.org/en/digitallibrary/publications/2015/02/beijing-synthesis-report (Retrieved on 21 February 2021) 
Chapter II

Sustainability in political thought 


\title{
The role of techno-optimism in environmental sustainability narratives \\ Lilla Sarolta BÁNKUTY-BALOGH ${ }^{44}$
}

\begin{abstract}
Techno-optimism, the belief that technology and technologists are building the future, is the paradigm based on which modern societies place faith in narratives of progress and technology eventually overcoming all emerging challenges. A techno-optimist view of environmental sustainability is centred around the notion that technology will be able to address ecological problems through the use of innovation, growing efficiency and (un)expected breakthroughs. The adoption of renewable and eco-friendly innovations is usually seen as the most important drivers of sustainability transformations, especially in the case of energy usage and consumption patterns. Although in policy narratives, a green technological revolution is often portrayed as the sole driver of sustainable change, we have to note that such revolution cannot happen without a societal transformation. Replacing two centuries of dominant socio-economic narrative that prizes economic growth above all, based on fossil energy and unconstrained use of natural resources might require more than technological innovation as the benign deus ex machina. Our aim is to uncover narratives in the public and personal spheres that can advance or hinder such sustainable transformation. The study is based on extensive review of related literature and secondary sources, and does not contain primary research, therefore it represents the opinion of the author based on cited literature.
\end{abstract}

Keywords: sustainability, techno-optimism, green growth, environmental narratives

\section{Introduction}

In the $21^{\text {st }}$ century we are facing significant technological changes which have already begun shaping our lives. The so-called fourth industrial revolution, similarly to the previous ones, fundamentally transforms our lifestyles, our ways of working and our social relationships. According to an expert on the topic, Klaus Schwab, founder of the World Economic Forum, the scale, extent, and complexity of this transformation will surpass any of the previous industrial revolutions. To support his theory, Schwab cites the impacts of the previous industrial revolutions on production: the first industrial revolution used steam power to mechanize production, the second created mass production with electric power, and the third used electronics and information technology to automate production. Now, the fourth industrial revolution, as continuation of the third, will implement the fusion of different technologies through digital revolution, blurring the lines between the physical, digital, and biological areas (SCHWAB 2016). As a result of the fusion of technologies, virtually everything can seem like a challenge that could be solved via a technological innovation. We rely on technology in our homes, in our education system, in health care, in financial services, in property management, and even in agriculture. However, the notion that technological innovation can solve any problem is not as straightforward as it seems to be at first glance. Unfortunately, for complex

\footnotetext{
${ }^{44}$ Corvinus University of Budapest, Doctoral School of International Relations and Political Science, PhD Student, lilla.s.balogh@gmail.com
} 
issues, simple solutions barely exist. This paper argues that technology in its current form cannot solve all challenges facing us, especially in relation with environmental issues, climate change and sustainability. This fundamental argument is supported through a thorough analysis of related scientific literature, however as we have no conclusive evidence at hand based on primary data, the paper itself is in accordance with the author's opinion and can be considered as a professional interpretation of the topic.

Techno-optimists tend to believe that, just as the application of technology has been a primary cause of environmental and climate issues, it must provide the primary solutions as well. Following this argument, it seems like a common understanding, that humanity will be able to solve environmental challenges primarily through technological advancement, while continuing to focus attention on economic growth. By following this approach, it is widely believed that we will be able to eliminate global poverty and raise the standard of living for all, without destroying necessary ecosystems that sustain life as we know it (ALEXANDER 2014). A broad definition of techno-optimism could be described as a belief that, through scientific and technological advancements, humanity will be able to solve all major social and environmental problems of our times, without having to fundamentally rethink the structure or goals of our growth-based economic philosophy or consider the environmental footprint of Western-style lifestyles. In other words, techno-optimism is the belief that the problems caused by economic growth can be solved by more economic growth, supposing that we learn how to produce and consume more efficiently through the application of science and technology. Proponents of this view argue that through advancements in knowledge and design, together with market mechanisms, we will be able to decouple our economic activity from its environmental impact, avoiding the negative implications that economic growth has on biophysical limits. Should any of our vital resources get scarce, we just simply assume that free and efficient markets and price sensitivity will incentivise more exploration or even the development of substitute resources (BECKERMAN 1992). Rather than questioning the very model of growth economics, the dominant narrative of techno-optimism advocates 'green growth' or 'sustainable growth' (PURDEY 2010), an oxymoron by itself, one could argue. This paper intends to provide a critical analysis of the techno-optimist narrative as sole driver of sustainable change by placing it in a theoretical context, and also by presenting the case of smart cities as an analogy for this techno-centric approach and its flaws. The aim of the analysis is to prove that technology cannot and will not solve environmental problems so long as it is applied within a growth-based economic model. In order to take advantage of efficiency gains, which are without doubt an essential part of the transition to a more equal and sustainable 
world, we argue that a value-shift is required away from the Economics of Growth toward a 'post-growth' or 'steady state' economy based on material sufficiency.

\section{Narratives of techno-optimism and environmental challenges}

Paul EHRLICH and John HOLDREN (1971) in their seminal article presented the socalled IPAT equation that shows clearly that environmental impact is influenced through factors like the size of population, per capita income, and increasing productive or energy efficiencies through technological development. The equation showed that continuous population and consumption growth would exacerbate environmental problems unless technological advancement outweighed those impacts through efficiency gains (ibid.). The message of the IPAT equation was on the one hand that individuals and policymakers have various options for tackling environmental problems. Those who care about the environment could try to lessen impact either by trying to reduce consumption, or by trying to produce and consume as efficiently as possible. However, it also suggested that if people or nations were unable or unwilling to tackle certain parts of the IPAT equation, they could still reduce impacts by addressing one or more of the other variables, and it ended up marginalising the reduction of consumption as environmental action, and prioritize technological fixes (HUESEMANN 2011). Indeed, this approach is fairly reasonable. Controlling population can have serious unintended social-economic-demographic effects that are equally - or even more - harmful than environmental effects. A similar dynamic could explain the side-lining of consumption reduction as an approach to sustainability. As a higher income is almost universally considered better than a lower income, governments and individuals have looked for other ways to decrease negative environmental impact. Reducing consumption is hardly a vote-winning political campaign slogan, especially in consumer-oriented societies most of us are living in. Nevertheless, the IPAT equation seemingly contains the win-win solution, we are seeking: improved efficiency through technological innovation. The equation suggests that all other factors should be put aside, it is still possible to reduce environmental impact through technological advancement. This 'techno-fix' approach provides a politically, economically, and socially much more attractive narrative to address environmental challenges. According to the same logic, this interpretation of the IPAT equation also opened up a strategy for the corporate world to try respond to environmental problems, in ways that would not interfere with interests of capital expansion. Businesses are in favour of increased consumption, not decreased demand. As a means of responding to environmental problems, therefore, technology companies have a clear incentive to privilege techno-fixes. Not only does this 
strategy conveniently avoid having to confront the non-profitable terrains of consumption reduction, but it also opens up a huge market for 'green products' which could be sold to a growing demographic of environmentally aware consumers and governments (PEARSE 2012).

Techno-optimism is a prominent ideology amongst companies that are directly involved in - and are gaining profit from - the widest possible spread of environmental-friendly, sustainable, zero-carbon cutting-edge solutions (TOWNSEND 2013). However, also in the wider public, to some extent we all tend to expect life-saving, almost miraculous solutions from technology companies which could reverse the negative effects of climate change and thereby help defeat the biggest threat of our age. This belief is nothing new, probably as old as humanity itself - to expect from technology the solution to all our challenges. To describe this, PINTÉR (2004, p.21) introduces the term Athens model. The Athens model is the paradigm of technophiles, who are convinced that "the technology is liberating and will increase the human well-being, resulted in a new electronic democracy - hence the name of the model: the direct democracy of the Greek city-state 2,500 years ago will make sense again in a new digital agora". Although, his argument is centred around the development of the information society, it could be interpreted in the context of the relation between technology and environmental sustainability as well. This Athens model approach is extremely popular even in the narratives describing the history of mankind, leading directly to the notion that we have nothing to fear about the future, because just as technological innovations have solved all challenges in the past, they will in the future as well (RIDLEY 2020).

The narrative of sustainable economic growth is just as prevalent as the 'techno-fix approach'. A study defines a so-called cooperative reformism narrative, which claims that economic growth is important for improving lives and should be pursued, as it generates wealth and wellbeing. Growth can be achieved by continuous improvements in technology and efficiency, that will allow us to increase GDP, profits, and jobs while still reducing pollution and preserving ecosystems. Therefore, it will not threaten workers or companies, since investments in clean technologies will have positive long-term impact, as sustainable companies are more efficient in the long-term. The process of moving towards a more sustainable economic system requires a concerted and collaborative effort in which everyone contributes to reducing their impact on our planet, but through these technological investments, generation by generation we can build a more sustainability-conscious society (STEVENSON 2019). Techno-optimism nowadays is fuelled by another phenomenon as well: the COVID-19 pandemic. The pandemic accelerated the adoptions of digital payments, distance learning, remote working solutions, telemedicine and industrial automation, serving as a reminder for 
us, that adversity often forces societies to advance, which could be easily paralleled with the fight against climate change (ECONOMIST 2021). Following this logic, we can assume that once the negative effects of climate change or environmental pollution become as devastating as the effects of the pandemic are today, we will be able and willing to switch to solutions that would stop those effects at once.

\section{Technology and climate change: are there positive changes?}

If a techno-centric approach really could have a positive contribution to the fight against the effects of climate change and to an environmentally sustainable lifestyle, there must be some testimony to this narrative. In the following section, we would like to present some samples on how the international community and technology companies are involved in 'green growth' and sustainability. We shall also investigate whether any positive effects on climate change of technological innovations are to be identified in the data. Afterwards, we analyse the justification of the Environmental Kuznets Curve, a model that could support the technooptimist paradigm.

Firstly, we would like to take into account some of the major trends of environmental sustainability and technological innovation:

- The OECD Environment Directorate has developed a project on Environmental Policy and Technological Innovation (EPTI) to investigate the effects of climate policy on technological development. With the aim of improving climate regulations whilst still allowing for innovation, the OECD views ICT as one of the critical industries ensuring the co-existence of economic growth and environmental improvement (OECD 2013). Figure 5 and 6 below, illustrate the exponential increase of some climate change-related technologies as positive examples of the technological progress in this field. Figure 6 also illustrates the strong correlation between energy prices and innovations related to alternative energy.

- The International Telecommunication Union (ITU 2019) identified two deep transformations of our age, the first one related to the so-called emerging technologies (artificial intelligence, 5G, blockchain etc.), and the other one being climate change. In order to reconcile environmental issues, the organisation - in accordance with the United Nations and its specialised agencies - believes that we must harness the digital revolution. To manage this process, the ITU has established a new Focus Group on Environmental Efficiency for Artificial Intelligence and other Emerging Technologies (FG-AI4EE) which raises awareness on the environmental impacts of frontier 
technologies on a global platform to contribute to the achievement of the Sustainable Development Goals and the objectives laid out in the Paris Agreement (ibid.).

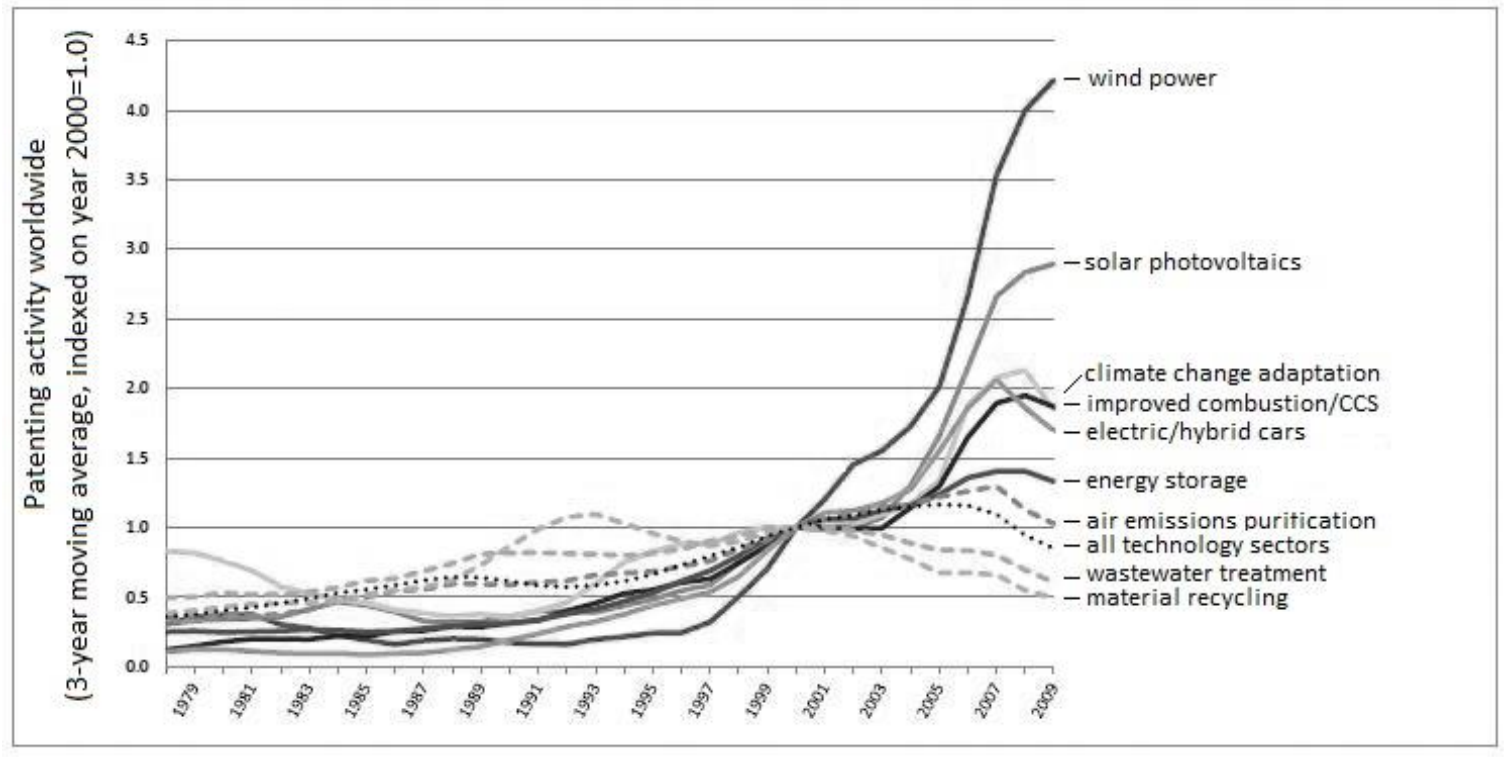

Figure 5: Innovation in environmental technologies, compared to all sectors. Source: OECD 2011.

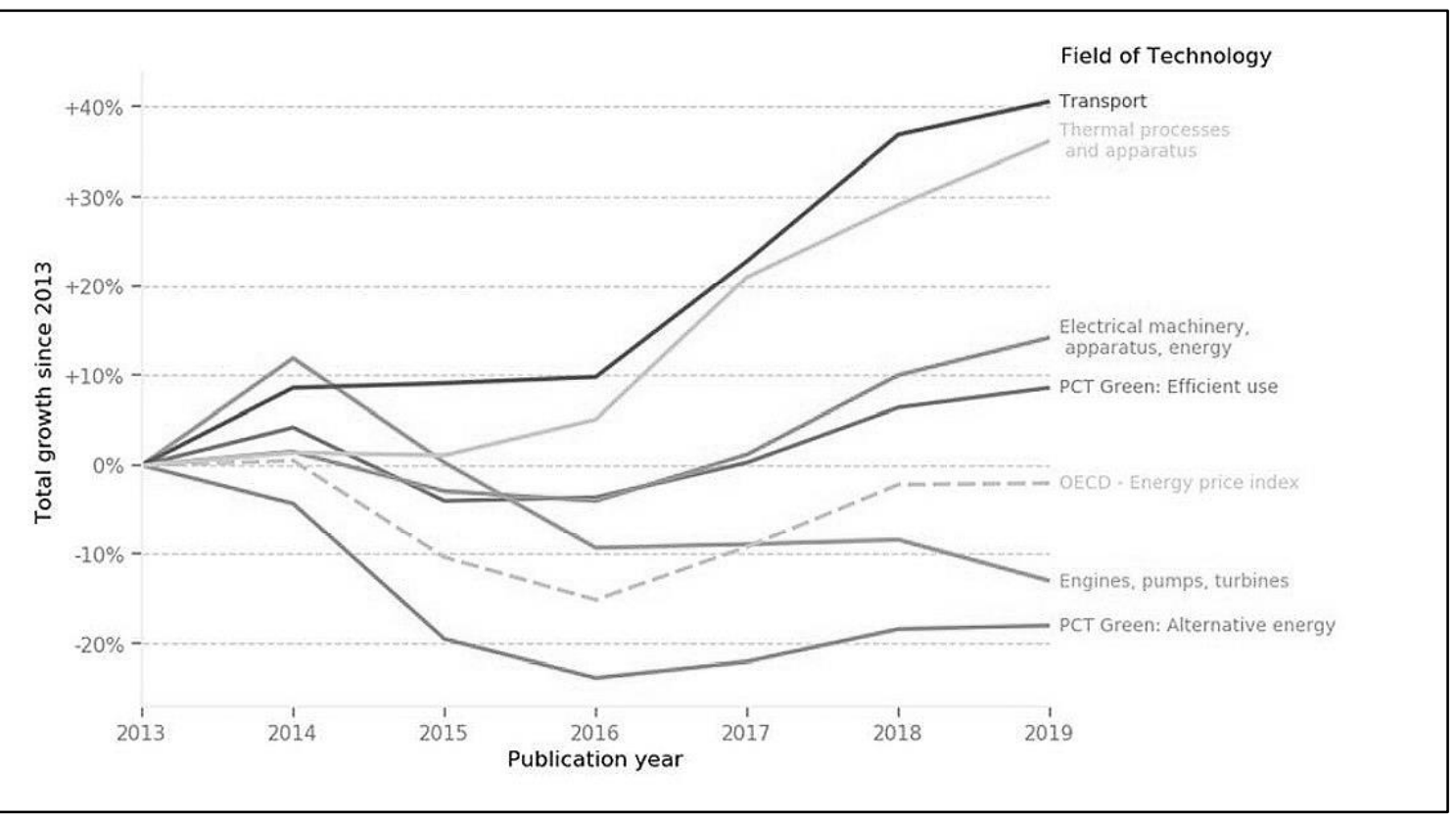

Figure 6: Technology trends between 2013-2019. Growth in green patent applications, \%. Source: WIPO 2020.

- Technology companies, such as IBM nowadays tend to pay more attention to environmental and sustainability issues. IBM has announced that it will achieve net zero greenhouse gas emissions by 2030 , to further its decades-long work to address the global climate crisis. To achieve this goal, the company undertakes to reduce its 
greenhouse gas emissions by $65 \%$ by 2025 against the base year of 2010, and to procure $75 \%$ of the electricity it consumes worldwide from renewable sources by 2025 , and $90 \%$ by 2030 , as well as to use viable technologies (in the future), such as carbon capture to remove emissions in an amount which equals or exceeds the level of IBM's residual emissions. As part of the pledge, the company joined the MIT Climate and Sustainability Consortium as part of the broader IBM Future of Climate Initiative (IBM 2021).

- Technology visionary, Bill Gates argues in his latest book, that effective climate change actions need - beyond technological innovations - coordinated policy measures, and governments must lead in this process, as technology alone cannot fix problems at hand. Although, he refers to himself a technophile, he also admits that innovation is not the only thing we need and argues that techno-fixes alone are not sufficient, but necessary (GATES 2021). Gates emphasizes that there is a need for action at all levels of government, from local governments (in determining building rules, energy rules, transportation systems, waste management etc.), through state or provincial governments (in regulating electricity, planning infrastructure etc.) to national legislatures (in shaping electricity markets, adopting pollution rules, create standards for vehicles and fuels, providing fiscal incentives and funding public R\&D activities etc.). Nevertheless, his argument is generally tech-centric, according to his starting point, the solution for the fight against climate change necessarily has to start with the technological advancements (ibid.).

After a brief overview of the global community and companies involved, we wanted to look at datasets describing climate change. The narrative, according to which technological innovation can reverse the effects of climate change is now almost 50 years old, therefore, we could assume that there should be some visible results from the previous decades in this relation. The latest assessment report of the Intergovernmental Panel on Climate Change (IPCC 2013:V) confirms that "warming in the climate system is unequivocal, with many of the observed changes unprecedented over decades to millennia: warming of the atmosphere and the ocean, diminishing snow and ice, rising sea levels and increasing concentrations of greenhouse gases. Each of the last three decades has been successively warmer at the Earth's surface than any preceding decade since 1850." Although this evaluation could be claimed as relatively outdated, unfortunately, recent data keep demonstrating similar trends, in spite of the significant and continuous technological change we have been experiencing in the last decades. A UK-based climate-related webpage CarbonBrief published already in July 2020 that the year 
could be the first or second warmest year on record (HAUSFATHER 2020a), and later in October it reaffirmed that 2020 will be the warmest year on Earth since reliable records began in the mid-1800s (HAUSFATHER 2020b). The report notes that it is all the more remarkable because 2020 lacks any major El Niño event, a factor that has contributed to most prior record warm years. Additional findings of the article claim that the first nine months of the year saw record concentrations of major greenhouse gases like $\mathrm{CO}_{2}$, methane, and nitrous oxide; that the Arctic Sea ice extent was also at record low levels for much of the summer; that six out of the first nine months in 2020 - January, April, May, June, July and September - saw record temperatures in at least one of the global surface temperature datasets; and that the rate of warming over the past 14 years is well above the long-term trend. These results are surprising also because during the spring of 2020, air pollution and the concentration of GHGs fell rapidly as the virus spread, and the global economic slowdown of the COVID-19 pandemic cut $\mathrm{CO}_{2}$ emissions by some 7\% throughout the year (VOOSEN 2021), which is just another sign that only dramatic action by the world's countries, far beyond existing efforts, can begin to put an end to such tendencies.

Official measurements released by the NASA show a significant and steady growing trend in the mean surface temperature from 1970 to 2020 (HAUSFATHER 2020b). What these graphs show is not a flattening curve (indicating that the temperature rise is declining), but an ever-intensifying increase. If technological innovation could effectively reverse trends, we should have been able to find some evidence in the figures, since the technology we are using today is fundamentally different from the technology of the 1970s; yet we cannot perceive any positive difference in the process of climate change. Another method to prove the positive effect of technological innovations on environmental sustainability would be the justification of the Environmental Kuznets Curve (EKC) hypothesis. Economist Simon Kuznets argued that income inequality first increases as a nation develops, but eventually, as a nation's economy continues to grow, levels of inequality begin to decline, leading to a broader distribution of wealth. A similar idea was later proposed with respect to environmental degradation, that became widely known as the 'Environmental Kuznets Curve'. The EKC hypothesis claims that an economy's environmental impact tends to increase during the early phases of industrialisation, but as a nation becomes richer, its environmental impact levels off and eventually begins to decline. The essential reasoning behind this hypothesis can be summarised as follows: (1) as GDP grows, nations can dedicate more of their attention and resources toward environmental protection (a so-called 'post-materialist' need), whereas the poorest nations must focus solely on meeting their basic material needs, irrespective of environmental impact; 
(2) richer nations will be able to develop and afford better technologies, which will make production cleaner and less resource-intensive; and (3) as nations get richer their economies tend to shift from 'industrial' economies to 'post-industrial' or 'information' or 'service' economies, which supposedly rely on lower material and energy flows (LOMBORG 2001). Based on this reasoning, the EKC hypothesis states that there are no environmental limits of growth, and that growth is ultimately good for the environment, even if at first it might seem contradictory. These narrative claims that limitless economic growth and caring for the environment is possible simultaneously. Empirical foundations of the hypothesis, however, are dubious, at best. In broad terms the empirical status of the EKC can be expressed as follows. Some studies have shown that where certain types of environmental damage are generated and suffered locally, an EKC can indeed be seen (DINDA 2004). These limited circumstances include wastewater discharge, $\mathrm{SO}_{2}$ emissions, and $\mathrm{CO}$ emissions. On the other hand, when environmental problems cross national boundaries or have longer-term impacts, studies conclude that the EKC does not hold (STERN 2010, KEREKES et al. 2018). Most importantly, an EKC exists neither for $\mathrm{CO}_{2}$ nor biodiversity loss (LUZZATI - ORSINI 2009), two of the most significant environmental crises. It is hard to defend a growth model based on the limited cases of environmental improvement if sustained growth in GDP fails to address (and indeed exacerbates) problems such as climate change or biodiversity loss.

A study by HOLM and ENGLUND (2009) has done much to debunk the widely held belief that a movement toward a 'service', 'information', or 'post-industrial' economy automatically leads to reduced environmental impacts. The authors show that despite the significant growth of the service sector during the last decades in the wealthier countries of the world, overall resource consumption has also increased. Moreover, the limited extent to which some 'service economies' do seem to be decoupling growth from environmental impact per capita, is arguably due to the outsourcing of manufacturing to developing nations, especially China - and now with China becoming more and more developed, the phenomenon continues to less developed Southeast Asian countries (HOLM - ENGLUND 2009). In one of the most comprehensive reviews of data and methodologies used to estimate the EKC hypothesis, David STERN (2004, p.1435) concludes that "the statistical analysis on which the EKC is based on is not robust. There is little evidence for a common inverted $U$-shaped pathway that countries follow as their income rises." One of the most serious criticisms of the EKC hypothesis, however, comes from the ecological footprint analysis. The EKC, if valid, would suggest that nations should seek growth in GDP if they want to reduce their environmental impact. But when this claim is considered in the context of ecological footprint analysis, the hypothesis 
seems to be negated by reality. The United States is the richest nation on the planet in terms of per capita GDP, however, if the American standard of living was globalised, we would need more than four times the biocapacity of Earth to sustain humanity (GFN 2017). Even the somewhat less resource-intensive Western European nations - the so-called 'green' economies like Germany, France, Norway, Denmark, Finland, and Sweden - are grossly exceeding their share of the planet's biocapacity (HICKEL 2020). These countries have the highest scores in the UN's Sustainable Development Goals (SDG) Index, but in fact - proving the flawed method of the index itself - some of them are the most environmentally unsustainable countries in the world. Another method developed by the UNIVERSITY OF LEEDS (2021) shows that all of the top-ranked countries in the SDG Index have significantly overused their fair share of planetary boundaries, in consumption-based terms - not only when it comes to resource use and emissions but also in terms of land use and chemical flows like nitrogen and phosphorous. Based on data regarding the consumption of the most developed countries, it can be concluded that even if there were an EKC, the tipping point in the curve would be occurring much too late in the process of development to validate anything like the conventional development path. Accordingly, the argument that sustainability will arrive when the entire world gets rich or 'developed' is demonstrably wrong, and it is intellectually irresponsible to pretend otherwise (WHITE 2007).

\section{A case study: smart cities}

The techno-centric approach toward the environmental and sustainability issues can be best illustrated with an analogy through a similar case. In the following section, we would like to give a brief overview of the contradictory narratives around so called 'smart cities'. The case of smart cities can serve as a proper illustration of the flawed hypotheses of a purely technocentric approach to development. A smart city means the extensive use - or, in other words: integration - of digital technological solutions in virtually every area of an urban entity (governance, mobility, economic development, security, waste management, planning, environmental issues etc.) to make it more effective, liveable and sustainable, in a nutshell: a better place for everyone to live in (ALBINO et al. 2015). In its purely technocratic form, the smart city narrative promises seamless mobility within the city, less pollution, on-demand services, less energy-use, a more just, more equal, greener, resilient and responsive city in perfect harmony with its environment and its residents (GREEN 2019). The term smart city was coined in the late $1990 \mathrm{~s}$, the tech companies started to apply the label from the middle of the 2000s as a common reference for complex ITC systems in urban infrastructure they 
provided (HARRISON - DONNELLY 2011). It was at that time, that the tech-companies began to create the first divisions dedicated particularly to urban development issues (e.g. IBM Smarter Cities, Siemens Smart City, Microsoft CityNext). This was the period of technooptimism in relation to smart cities, determined and driven almost exclusively by technology companies (COHEN 2015). The academic sphere, researchers from the fields of urban studies or social studies joined the discourse only after that, and uncovered many concerns related to smart cities and threats the smart cities could induce (TOWNSEND 2013). The main problem with techno-fixes in cities and techno-centred narratives in urban development is that it does not take into account that urban life is not primarily about finding an optimum and taking full advantage of potentials. Serious concerns emerged that smart city initiatives will deepen inequalities between cities and within cities, between different social groups, between groups with different income levels, and that such developments will exclude certain groups of people, and some groups will benefit from innovations much more than others (SASSEN 2012, VANOLO 2014). On top of that, there is no evidence that smart city developments could even achieve certain goals set by the technology companies. Almost two decades have passed since the concept was introduced, but the most pressing urban issues are still with us: we could not solve the problem of traffic jams, the problem of poor air quality of cities, the challenge of securing affordable housing for urban residents, and overall, the urban inequality issues have worsened in recent years instead of improving (BARLOW - LÉVY-BENCHETON 2018). The point is that in this case, it seems that a techno-centric approach in itself could not effectively solve complex urban issues, and after the initial hopeful years, now even the most ambitious technology companies acknowledge that fact as well. There is a growing consensus nowadays, that exclusively technology-driven urban development tends to be the least favourable and least effective one (GREEN 2019). Development can achieve the most positive outcomes if as many participants are involved in the process as possible, namely the local government, the authorities, the academic sphere, the service providers and also the citizens themselves (civil groups, NGOs) (COHEN 2015), besides just tech-companies (WOETZEL - KUZNETSOVA 2018).

\section{An outlook on economic growth}

The so-called 'green growth' approach, based on a profound faith in technological solutions, has come to define our times. There are occasional comments regarding the issue of overpopulation or the importance of not over-consuming, but the reality is that mainstream environmental discourse, especially in the political realm, has placed its faith, explicitly or 
implicitly, almost entirely in techno-fixes. This would mean that we expect to reduce (eventually to zero) our environmental impact almost exclusively by producing and consuming the same goods and services more efficiently, which concept is in itself paradoxical. The argument holds, that this way, economies can still grow in terms of GDP, while environmental impact reduces. This, in essence, is part of the vision encapsulated within notions of 'sustainable development' and 'green growth'. It is so convenient that governments, businesses, and the general population tend to accept it without further inquiries into the specificities, irrespective of whether it has much empirical support. Perhaps the limits of technology can be most easily understood when clarifying exactly what is expected of technology in terms of achieving sustainability. Throughout much of the 20th century, developed economies achieved around 3\% growth in GDP annually, meaning that they doubled in size roughly every 23 years. This has become a reference point for signifying politicaleconomic success, so let us assume that when the United Nations talks of 'growth' it means continuing levels of growth that have been experienced in recent decades. Over eighty years, at $3 \%$ growth, the economies of the developed world (populated by roughly 1 billion people) would have doubled in size three times, meaning they would be eight times larger, in terms of GDP, than they are now. If we also assume that by 2100 the world population is going to be around 11 billion (UNDESA 2019) and that this population has caught up to the living standards of the developed world by this stage, then the global economy would be almost 90 times larger, in terms of GDP, than the size of the developed world's aggregate economy today. Considering that ecosystems are trembling under the pressure of one 'developed world' at the existing size, no one could seriously think our planet could withstand the equivalent of a 90fold increase. There would be efficiency improvements, indeed, meaning that the impact could be significantly less than projected above, however, even based on estimates of decoupling, we would still need several planets worth of biocapacity (WEIDMANN et. al. 2015). The point is that efficiency gains could not possibly be expected to make the projected amount of GDP growth sustainable. The levels of decoupling required would simply be too much. Therefore, according to some experts, we should no longer focus on how to make our current growth model sustainable but rather to find out what economic model is sustainable at all (ALEXANDER 2014).

We can find narratives other than 'perpetual economic growth', although these are mostly theoretical ones, only vaguely developed and described. However, it is still worth paying attention to them because the following phase of this research could be finding a solution for a sustainable economic model through a deeper understanding of socio-economic 
narratives. GUSKE et al. (2019) in their article propose the narrative of 'Small is beautiful' as a direct reference to the original concept of E. F. SCHUMACHER (1973), which refers to a complete reconfiguring of our economic system. According to this narrative, the structure of the economy is organized around small or medium-sized, local enterprises. These are mostly decoupled from international value chains and independent from global corporations. Instead, local businesses keep supply-chains local, try to use alternative resources and production methods, which will eventually lead to a replacement of international supply-chains. According to the authors, in this more sustainable economic system, a fundamental value shift has taken place. Economic growth is no longer the prevailing indicator for success and well-being; consumers no longer consider owning goods such as the latest fashion items or the newest technology a status symbol; producers no longer invest in excluding others from using valuable knowledge. Instead, community-oriented values prevail, putting well-being and a good life at the heart of society, which includes quality of life, social cohesion and participation. A different narrative from the same authors (ibid.) is named 'Transparent and manageable', where the economy is built on more sustainable production and consumption patterns, achieved by increasing transparency of international supply-chains and stricter standards regarding the environmental and social impact of products. Sustainable solutions are no longer more expensive, rather they are competitive in markets. This change in focus results in a change of the overarching economic goals. Producing and selling more goods, increasing profit margins and ultimately growing in terms of revenue is no longer the main goal, instead, network effects resulting from a higher number of users of sustainable solutions gain relevance. STEVENSON (2019) introduces the 'Radical Transformationism' narrative, according to which we have to accept that environmental sustainability is completely incompatible with continuing economic growth. This narrative rejects capitalism as the only viable economic system - in fact it claims that environmental sustainability is completely incompatible with continuing economic growth -, and recommends an alternative to our existing market-based economies through strengthening economic relations based on cooperation and sharing. Existing market-based environmental solutions are part of the problem not part of the solution, the narrative claims. This perspective is also associated with a fairly high level of scepticism about the existing sustainability initiatives of businesses, governments, and international institutions.

\section{Conclusions}

We have evidence that as nations get richer, their overall ecological footprints and carbon emissions tend to rise, from which it follows that the argument that higher GDP will 
automatically produce sustainable economies (which is the EKC hypothesis) lacks evidential foundation. The main problem is that according to the narrative of growth-orientated economy, efficiency gains are almost always reinvested into increasing production and consumption, not reducing them. These rebound effects have caused the overall environmental impact of economies to increase, even though technology has produced many efficiency gains in production and cleaner solutions. In other words, technological advancement has resulted in relative decrease, but little or no absolute decrease of emissions and natural degradation. The latter is what is needed, however, given that the global economy is in serious ecological overrun. Since there seems to be no reason to assume that more efficient growth is going to reduce humanity's ecological footprint within sustainable bounds, it follows that we must consider alternative models of economy - alternative models of progress - even if this challenge conventional economic wisdom. We cannot solve our problems using the same kinds of thinking that caused them. All appropriate technologies must be exploited - this paper does not argue otherwise -, it only maintains that technology by itself is not going to be able to solve environmental problems when the application of technology is governed by a growth imperative. Accordingly, this paper has argued that what is needed for true sustainability is a transition to a fundamentally different kind of economic thinking - an economic paradigm that seeks sufficiency rather than limitless growth. This may not be a popular message, and it may already be too late for a smooth transition from the infinite growth model (GILDING 2011), however, on a finite planet, currently there seems to be no alternative. Although this hypothesis hereby cannot be validated through empirical research - which was also not the purpose of this paper -, the professional opinion of the author reflects that there seems to be strong evidence that techno-optimism by itself cannot be the ultimate solution for problems emerging from global sustainability issues.

\section{References}

ALBINO, V. - BERARDI, U. - DANGELICO, R. M. 2015: Smart Cities: Definitions, Dimensions, Performance, and Initiatives. Journal of Urban Technology, 22(1), pp. 3-21. doi: 10.1080/10630732.2014.942092.

ALEXANDER, S. 2014: A Critique of Techno-Optimism: Efficiency without Sufficiency is Lost. Post Carbon Highways, Working Paper Series 1/14, University of Melbourne, Melbourne Sustainable Society Institute.

BARLOW, M. - LÉVY-BENCHETON, C. 2018: Smart Cities, Smart Futures - Showcasing Tomorrow. Hoboken: John Wiley \& Sons Inc. 
BECKERMAN, W. 1992: Economic growth and the environment: Whose growth? Whose environment? World Development 20(4), pp. 481-496.

COHEN, B. 2015: The 3 Generations of Smart Cities - Inside the development of the technology driven city. Fast Company, October 8, available at: https://www.fastcompany.com/3047795/the-3-generations-of-smart-cities (6 May 2021)

DINDA, S. 2004: Environmental Kuznets curve hypothesis: A Survey. Ecological Economics 49(4) pp. 431-455.

ECONOMIST 2021: Why a dawn of technological optimism is breaking. The Economist Online, available at: https://www.economist.com/leaders/2021/01/16/why-a-dawn-oftechnological-optimism-is-breaking?itm_source=parsely-api (6 January 2021)

EHRLICH, P. - HOLDREN, J. 1971: Impact of population growth. Science 171(3977), pp. $1212-1217$.

GATES, B. 2021: How to Avoid a Climate Disaster: The Solutions We Have and the Breakthroughs We Need. Borzoi Book, New York: Alfred A. Knopf.

GFN (2017): Biocapacity of the countries of the Earth, 2017. - Global Footprint Network, available at: https://data.footprintnetwork.org/\#/ (20 January 2021)

GILDING, P. 2011: The great disruption: How the climate crisis will transform the global economy. London: Bloomsbury Publishing.

GREEN, B. 2019: The Smart Enough Cities: Putting Technology in Its Place to Reclaim Our Urban Future. Cambridge, Mass, The MIT Press Strong Ideas Series.

GUSKE, A. - JACOB, K. - HIRSCHNITZ-GARBERS, M. - PEUCKERT, J. - SCHRIDDE, S. - STINNER, S. - WOLFF, F. - ZAHRNT, D. - ZIESEMER, F. 2019: Stories that Change Our World? Narratives of the Sustainable Economy. Sustainability, 11(21) p. 6163. https://doi.org/10.3390/su11216163.

HARRISON, C. - DONNELLY, I. A. 2011: A Theory of Smart Cities. Proceedings of the 55th Annual Meeting of the ISSS, International Society for the Systems Sciences, Full Paper, pp. 1-15.

HAUSFATHER, Z. 2020a: State of the climate: 2020 set to be first or second warmest year on record. CarbonBrief, 30 July, available at: https://www.carbonbrief.org/state-of-theclimate-2020-set-to-be-first-or-second-warmest-year-on-record (25 January 2021)

HAUSFATHER, Z. 2020b: State of the climate: 2020 on course to be warmest year on record. CarbonBrief, 23 October, available at: https://www.carbonbrief.org/state-of-the-climate2020-on-course-to-be-warmest-year-on-record (25 January 2020) 
HICKEL, J. 2020: The World's Sustainable Development Goals Aren't Sustainable. Foreign Policy, available at: https://foreignpolicy.com/2020/09/30/the-worlds-sustainabledevelopment-goals-arent-sustainable/ (20 January 2021)

HOLM, S. - ENGLUND, G. 2009: Increased ecoefficiency and gross rebound effect: Evidence from USA and six European countries 1960-2002. Ecological Economics 68(3) pp. 879887.

HUESEMANN, M. 2011: Techno-fix: Why technology won't save us or the environment. Gabriola Island: New Society Publishers.

IBM. 2021: IBM Commits to Net Zero Greenhouse Gas Emissions By 2030. IBM official press release, available at: https://newsroom.ibm.com/2021-02-16-IBM-Commits-To-NetZero-Greenhouse-Gas-Emissions-By-2030 (1 March 2021)

IPCC. 2013: Climate Change 2013: The Physical Science Basis. - Contribution of Working Group I to the Fifth Assessment Report of the Intergovernmental Panel on Climate Change. Cambridge University Press: Cambridge, United Kingdom and New York, NY, USA.

ITU. 2019: Focus Group on Environmental Efficiency for Artificial Intelligence and other Emerging Technologies (FG-AI4EE). International Telecommunication Union, available at: https://www.itu.int/en/ITU-T/focusgroups/ai4ee/Pages/default.aspx $\quad(20$ February 2021)

KEREKES, S. - SZERÉNYI, Zs. - KOCSIS, T. 2018: Sustainability, environmental economics, welfare. Corvinus University of Budapest, Budapest https://doi.org/10.14267/cb.2018k05

LOMBORG, B. 2001: The skeptical environmentalist: Measuring the real state of the world. Cambridge: Cambridge University Press.

LUZZATI, T. - ORSINI, M. 2009: Investigating the energy-environmental Kuznets curve. Energy 34(3) pp. 291-300.

OECD. 2011: Innovation in Environmental Technologies, Compared to All Sectors. Environmental Policy and Technological Innovation (EPTI), OECD official website, available at: OECD 2011, available at: https://www.oecd.org/environment/innovation.htm (5 January 2021)

OECD. 2013: Environmental Policy and Technological Innovation (EPTI). Brochure, OECD Environmental Directorate, available at: https://www.oecd.org/env/consumptioninnovation/Brochure\%206\%2003\%202013.pdf (20 February 2021)

PEARSE, G. 2012: Greenwash: Big brands and carbon scams. Melbourne: Black, Inc. 
PINTÉR, R. 2004: A magyar információs társadalom fejlődése és fejlettsége a fejlesztők szempontjából. (The development of the Hungarian information society from the developers' point of view.) PhD thesis. Budapest: Eötvös Loránd Tudományegyetem Társadalomtudományi Kar.

PURDEY, S. J. 2010: Economic growth, the environment, and international relations: The growth paradigm. New York: Routledge.

RIDLEY, M. 2020: How Innovation Works - And Why It Flourishes in Freedom. Harper London: Collins Publishers Ltd.

SASSEN, S. 2012: Urbanising technology. Urban Age Electric City Conference, London 6-7 December 2012, 12-14, pp. 12-14., available at https://lsecities.net/wpcontent/uploads/2012/12/the-electric-city-newspaper.pdf (6 May 2021)

SCHUMACHER, E. F. 1973: Small is Beautiful: Economics as if People Mattered. London: Blond and Briggs.

SCHWAB, K. 2016: The Fourth Industrial Revolution: What It Means and How to Respond. Foreign Affairs, Special Issue (2016) pp. 2-11.

STERN, D. 2004: The rise and fall of the environmental Kuznets curve. World Development 32(8) pp. 1419-1439.

STEVENSON, H. 2019: Contemporary Discourses of Green Political Economy: A Q Method Analysis. Journal of Environmental Policy \& Planning, 21:5, pp. 533-548.

TOWNSEND, A. M. 2013: Smart Cities: big data, civic hackers, and the quest for a new utopia. New York: W. W. Norton \& Company, Inc.

UNDESA. 2019: World Population Prospects 2019: Highlights. United Nations, available at: https://population.un.org/wpp/Publications/Files/WPP2019_10KeyFindings.pdf December 2020)

UNIVERSITY OF LEEDS. 2021: A Good Life for All Within Planetary Boundaries. Country comparisons. University of Leeds, available at: https://goodlife.leeds.ac.uk/countries/ (20 January 2021)

VANOLO, A. 2014: Whose smart city? OpenDemocracy.Net, April 8., available at https://www.opendemocracy.net/opensecurity/alberto-vanolo/whose-smart-city (6 May 2021)

VOOSEN, P. 2021: Global temperatures in 2020 tied record highs. Science, Jan 14., available at: https://www.sciencemag.org/news/2021/01/global-temperatures-2020-tied-recordhighs (25 January 2021) 
WIEDMANN, T. O. - SCHANDL, H. - LENZEN, M. - MORAN, D. - SUH, S. - WEST, J. - KANEMOTO, K. 2015: The material footprint of nations. Proceedings of the National Academy of Sciences, 112(20) pp. 6271-6276. https://doi.org/10.1073/pnas.1220362110. WHITE, T. J. 2007: Sharing resources: The global distribution of the ecological footprint. Ecological Economics 64(2) pp. 402-410.

WIPO. 2020: World Intellectual Property Day 2020: Green Innovation Surge Needed to Address Climate Change, New WIPO Figures Show. World Intellectual Property Organization, Geneva, April 23 (PR/2020/851). Annex 1, available at: https://www.wipo.int/export/sites/www/pressroom/en/documents/pr_2020_851_annex.p df (6 May 2021)

WOETZEL, J. - KUZNETSOVA, E. 2018: Smart city solutions: What drives citizen adoption around the globe? McKinsey Center for Government, available at: https://www.mckinsey.com/industries/public-and-social-sector/our-insights/smart-citysolutions-what-drives-citizen-adoption-around-the-globe (15 December 2020) 


\title{
Can the trilemma of environmental policy be solved? Izabella FEIERABEND ${ }^{45}$
}

\begin{abstract}
In this paper I will analyse the main obstacles which prevent sustainable economic growth from being achieved. I define the sustainability problem as the impossible trinity of environmental policy. In my paper I will describe the trilemma and at the same time, I will assess the effectiveness of different policy instruments such as taxes and subsidies from an institutional economics point of view. The main research question is: to what extent can innovation strategies and specifically digitalisation contribute to meeting the EU decarbonisation goals? In my research I will carry out a statistical analysis (multiple regression) to assess the strength of the correlation between institutional stability, innovativeness, competitiveness, and environmental performance.

To be able to achieve a climate neutral Europe by 2050, policymakers must proceed with the implementation of measures, adapt institutional frameworks, and promote well-targeted, coordinated investments.
\end{abstract}

Keywords: sustainability, economic growth, institutional economics, innovation

\section{Introduction: The notion of the impossible trinity}

The term, "impossible trinity" is known in the context of international finance and refers to the impossibility of meeting three important goals; in other words, only two of them are achievable at the same time, whereas the third one has to be sacrificed (AIZENMAN et al. 2013; MAGAS 2008). FRANKEL (2003) applied the same term to global environmental regulation. In his view globalisation, the regulation of externalities and national sovereignty jointly constitute a trilemma, yet in the case of an open economy which would like to take advantage of globalisation and a global market, externalities will be produced at a global level, making global regulation necessary, which would somehow restrict national sovereignty (FRANKEL 2003).

In my paper, I would like to introduce a different interpretation of the trilemma. In environmental policy we must reduce negative environmental impacts and ensure economic growth while still considering society's standards of living (Figure 7).

For the moment achieving these three goals seems to be impossible because neither the current economic structure, nor the present stage of technological development, nor the formal and informal institutional environment guarantee a solution for the trilemma. The aim of this study is to identify which factors prevent sustainable growth from being achieved and answer the question of whether we really do face an impossible trinity or instead, the problem can be solved by the application of well-targeted policy measures.

\footnotetext{
${ }^{45}$ Corvinus University of Budapest, Doctoral School of International Relations and Political Science, PhD candidate, Department of Comparative and Institutional Economics, lecturer, izabella.feierabend@unicorvinus.hu
} 


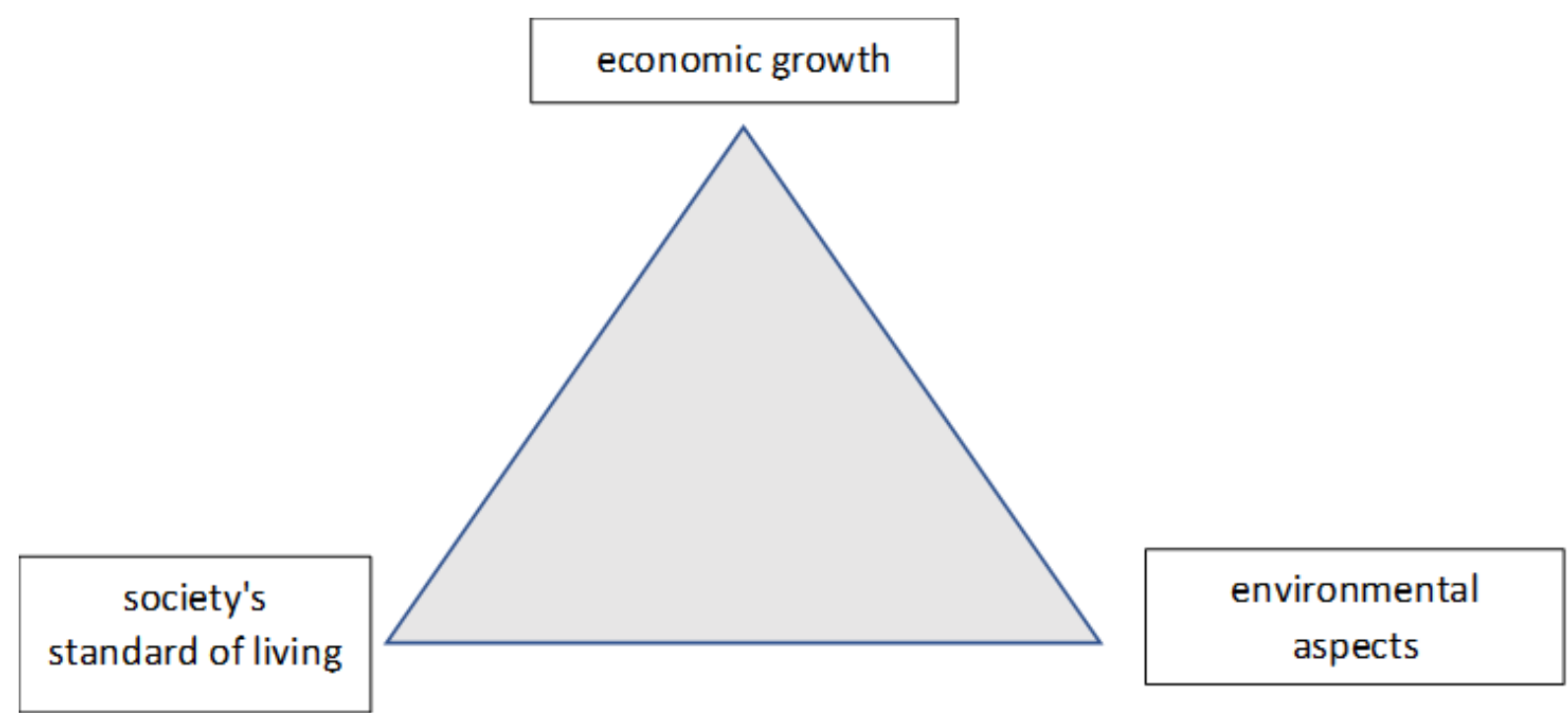

Figure 7.: The impossible trinity of environmental policy Source: The author

\section{The description of the trilemma}

The main challenge of environmental policy is to achieve low-carbon economic growth without reducing social welfare. Growth theories have a broad literature; in my argumentation, I will focus on the Solow model and its revision, the green Solow model (SOLOW 2008; BROCK - TAYLOR 2010). GDP growth can essentially be guaranteed by technological development. If the progress in green technologies surpasses the progress in non-environmental technologies, the resultant abatement level will be higher than the marginal externality from the augmented production. Therefore, the economy could reach a sustainable growth. Economic growth does not necessarily result in higher environmental pressure, because by applying energy-efficient, low-carbon technologies, higher productivity can be achieved while the economy produces fewer negative externalities. The Brock-Taylor model is in line with the theory of EKC (Environmental Kuznets Curve) although its critics suggest that it cannot be generalised (ARROW et al. 2005; STERN 2004). Extremists argue that all kinds of economic growth must be stopped, or at least we must put an end to every kind of physical growth. We shall now analyse the two approaches in detail.

Suppose that we would like to improve environmental performance by technological innovations it is generally inevitable to raise capital, as these innovations are usually capitalintensive. Therefore, production costs will rise and depending on market conditions, these extra costs will be built in the price of the product. If there is a fierce competition within a dynamic market structure, where there are various suppliers and various perfect or nearly perfect 
substitute products, consumers have more bargaining power. In this case, producers cannot charge all the extra production costs to the consumer, consequently the consumer surplus reduction and the social dead-weight loss will be lower. In case of an oligopoly or monopoly, the social welfare loss will be higher since the extra cost can be imposed on consumers. It is rather difficult how to measure social welfare ${ }^{46}$, hence defining social welfare as the social surplus is an inconvenient but necessary simplification, with many restrictions, and fails to assess numerous important factors: the adoption of low-carbon technologies reduces pollution, meaning that environmental quality and quality of life become better. In the long run, consumers benefit from the positive externalities of technology change. At the same time, it must be considered that consumers have different preferences, they have different reservation prices for environmental-friendly goods, and different discount rates for long-run environmental benefits.

It is supposed that environmental regulation by negative incentives or economic structural change driven by the reduction of the output, would raise consumer prices in case of products, which are essential goods for consumers in general or for some groups of consumers. For those whose reservation price is below the new, augmented market price, they won't be able to afford to buy some of the goods, and the consumer surplus will decrease. The reduction of production on the short run might enable to meet environmental goals without harming consumer surplus, however on the long run the decrease of economic growth will finally result in the reduction of economic competitivity, development, consequently lower employment rate and lower social welfare. Although sectorial change, moving towards quality improvements in spite of physical growth, in a knowledge economy driven by intellectual capital, is a long-term process, and needs positive incentives (from the market or the state) it has a much better outcome than the instantaneous restraint in production.

The economic recession due to Covid-19 pandemic reflected that in case of a severe economic downturn pollution initially drops as economic activity slump, however it entails high social costs, as we have experienced and many sectors (LÓPEZ-FELDMAN et al. 2020; WANG - SU 2020). Moreover, rebooting the economy made necessary fiscal and monetary interventions, which led to even higher emissions (OECD 2020). The pandemic restrictions

\footnotetext{
${ }^{46}$ Social welfare or social well-being is broadly discussed in economic literature (RAWLS, 1982; SEN, 2003; KOCSIS, 2010; ARROW, 1996). Without taking any position in the theoretical debate, we can accept that income growth will result in a higher consumer utility, however this is not equal to the subjective perception of wellbeing. According to Amartya SEN income is a means of carrying out activities, which cannot be monetised. RAWLS suggests that there are some primary goods, which are necessary to achieve some other specific goals. Therefore, indirectly income can be an indicator of social welfare.
} 
and the period of confinement highlighted that business rationalisation even during an economic recovery is of crucial importance in environmental management, and it can reduce emissions to a great extent without restricting economic activity. For instance, non-standard employment strategies, such as teleworking, online conferences, webinars contribute to a reduction in the energy usage of the office buildings, and prevent $\mathrm{CO}_{2}$ emissions due to commuting, transport. The vis major situation forced the different actors to make use of online solutions, which has made accessible a more connected, more resource-efficient, paperless future (in areas such as online administration in the public sector, healthcare, education, and ebusiness solutions).

The third variety of the impossible trinity is targeting economic growth and social welfare, which would mean the maintenance of the status quo, the present economic structure. This means that substantial improvement in environmental quality cannot be achieved, only mitigation of the environmental pressure is possible. This path, however, is not sustainable, since growing environmental impacts will inevitably harm the quality of life and health, and will result in rising prices for non-renewable resources, hampering economic stability and consequently making it difficult to guarantee purchasing power and hence high living standards.

\section{Policy measures to solve the trilemma}

\subsection{The role of subsidies in handling market failures}

After dealing with the target system of the impossible trinity, I will assess whether environmental policy measures can efficiently address the challenge.

The first problem is elevated consumer prices due to the high costs of green innovation. The other challenge is that firms face difficulties financing environmental innovations which prevent these innovations from being carried out. Furthermore, an economic slowdown due to negative incentives harms social welfare. In the following section I will analyse whether the existing institutional environment can reduce consumers' surplus loss and boost producers' innovation potential.

One possibility of fostering innovations is providing subsidies, especially at an earlier stage of development, during the proof-of-concept phase which involves many uncertainties and entails high costs.

When carrying out a cost-benefit analysis of subsidies the following factors should be taken into account. By giving subsidies policy makers would like to reduce market failures and 
eliminate innovation barriers to green investments. Environmental services and natural resources are public goods, therefore their production is not necessarily viable financially, and market actors are not motivated to produce them, which leads to a market failure.

Market failures arise due to different reasons:

1. The market does not reward environmentally conscious behaviour of firms, or green products. This can be handled in different ways apart from subsidies, for example through informal institutions such as environmental rankings and green awards from the supply side and by making use of "framing effect" to form consumer preferences from the demand side.

2. High costs of capital also entail a market failure. In the continental Europe the banking sector plays the most important role in long-term and medium-term financing which is a lot more expensive than equity financing (which is more common in the US, and Great Britain) (GEDEON 1992). Venture capital investments are less habitual, moreover state-owned venture capital funds predominate, which is a less competitive structure than the dominance of private venture capital funds, due to the fact that private venture capital funds take into account competitivity and market potential while selecting innovations. In contrast, stateowned companies may easily fail to assess competitiveness and channel venture capital and subsidies to the same investment projects, meaning that it is not the most innovative firms who succeed in gaining access to financial sources (KARSAI 2007).

Subsidies, by the initial capital injection, make it possible to realise the investment with less financial risks and to launch green products on the market at a competitive price (it is not the consumers who have to pay a premium for the environmentally friendly aspect).

In the cost-benefit analysis we should take into account as positive externalities of subsidies the promotion of innovations, the technological spill-over effect of investments and their contribution to sustainable GDP growth. Nevertheless, the question arises: how can we assure that subsidies do not become environmentally harmful subsidies? It is necessary to study whether positive externalities can offset negative externalities arising from the increase in economic activities and it must be assured that the most competitive investments get subsidised and that counterselection is avoided.

ACEMOGLU et al. (2012) pointed out that subsidies are essential to ensuring that green technologies displace pollutant technologies. According to them, a combination of subsidies and taxes could be the key to directing innovation activity towards more sustainable technologies. It is also important to emphasise that without strict monitoring systems and the 
possibility of imposing sanctions it cannot be guaranteed that green investments will achieve the desired effect.

We are talking about an environmentally harmful subsidy if in the long run it results in higher environmental pressure despite guaranteeing better environmental performance (KISS 2003). According to the EU methodology, in the cost-benefit analysis (which is the basis upon which governmental organisations can decide about the eligibility of a project for national or European subsidies) all positive and negative externalities must be taken into account, or quantified (EC 2008). Economic net present value must be calculated in this way, however in cost-benefit analysis gains are usually overcalculated while costs are underestimated (KEREKES et al. 1993). Information asymmetry problem arises as well, yet the investor has lot more precise information on the social, environmental, and economic effects of the investment, however as investors are interested in getting the subsidy, they tend to paint a more positive picture of the project. Therefore, independent auditors need to monitor the project results, something which elevates the aggregate costs of subsidies to a great extent.

Consequently, only at very high costs can it be assured that subsidies do not become environmentally harmful subsidies. If subsidies cannot achieve the expected outcome, market failure cannot be successfully handled, and it is converted into government failure. Another prerequisite of proving subsidies is that the investment be financially viable and sustainable. This factor and the high transaction costs of getting information prevents SMEs from participating in innovation competition (KISS 2005; KISS 2009; HÁMORI - SZABÓ 2012). The precondition of carrying out a well-targeted environmental policy aimed at tackling innovation barriers by subsidies is that smaller market actors, SMEs and micro-enterprises be able to access information at a lower cost, and to achieve a higher level of confidence in economic and political institutions. If already financially strong enterprises are subsidised, while SME sector (that has major contribution to employment) is underrepresented in green innovation, the innovation gap is reproduced, although Pareto-improvement has been achieved.

\subsection{Negative incentives to tackle market failures or empowering market incentives to foster voluntary environmental engagement}

Other institutional solution aimed at internalising externalities is the introduction of negative incentives into the regulatory system, to reduce polluting activities and promote innovation. The second of these two goals can only be achieved (although not in every case) if there is a fierce competition in the sector with multiple actors and where the lack of innovation activities would result in competitive disadvantage and loss of market power. Essentially, it 
depends on market institutions and formal economic institutions as to whether negative incentives can exert an innovation-promoting effect or whether instead they result in the reduction of production and/or inflation. It can be supposed that if a company reacts to environmental restrictions by innovating (despite reducing its production), it could meet environmental standards with the same or even higher productivity (Figure 8). Consequently, an ecotax will not put extra charge on production and the firm can remain competitive in prices (FEIERABEND 2011).

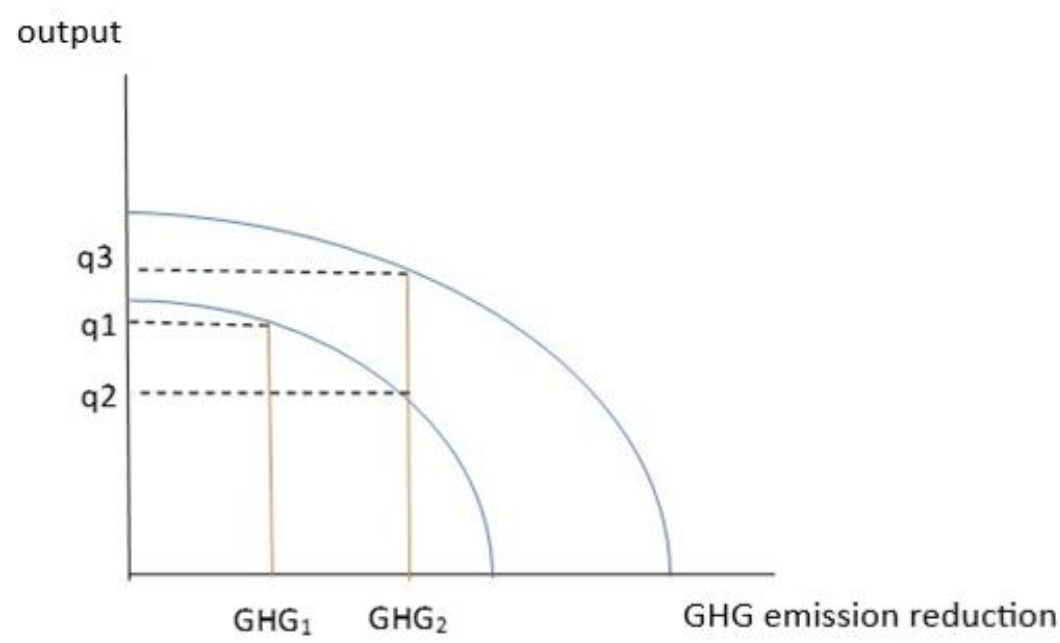

Figure 8: The effect of technological innovation on productivity, meeting GHG reduction goals Source: FEIERABEND 2011, p. 130.

Consequently, technological innovation results in a more cost-efficient production method with better environmental performance. As the production possibilities curve shifts up, pollution norms can be met or overperformed with higher productivity.

If it is so, why do economically and technically supportable innovations not become a reality? The reasons for this can be due to market imperfections, and the internal characteristics of the enterprise, which can be analysed from a behavioural economic approach. There is a time lag between the initial (high) investment costs and the return on investment. There can be a substantial conflict of interest between the owners (with long-term interests) and managers (with short-term interests), the latter tending to be risk averse. Complex decision-making processes might prevent environmentally efficient innovations from being carried out due to market risks, and another reason might be companies having negative cash flow at the beginning of the innovation process. Companies might tend to make suboptimal technical changes to meet environmental requirements while reducing the amount of taxes to pay. 


\section{Do environmental regulations ensure better environmental performance?}

On a theoretical basis I have argued that environmental policy measures, positive and negative incentives might not achieve the desired environmental goals. In my empirical analysis I will use the Environmental Policy Stringency (EPS) index developed by OECD $^{47}$ to measure the depth of environmental policy measures, and I would like to analyse whether there is a correlation between EPS and environmental performance (measured in $\mathrm{CO}_{2}$ emissions per GDP PPP, on 2015 basis).

Since policy measures generally have their effect in the long run, and not instantly, I will carry out a statical linear regression analysis with 3,5 and 10 years of time lag. The latest data on EPS is of 2012 for all countries involved in the analysis ${ }^{48}$.

The result of the linear regression (Table 3) suggests that there is practically no correlation between environmental policy stringency and environmental performance. We have a similar result $\left(\mathrm{R}^{2}=0.011\right)$ in case of running linear regression on EPS (2012) and productivity-based $\mathrm{CO}_{2}$ emissions.

\begin{tabular}{|l|c|c|c|c|}
\hline \multicolumn{5}{|c|}{ Model Summary } \\
\hline Model & $\mathrm{R}$ & R Square & $\begin{array}{c}\text { Adjusted R } \\
\text { Square }\end{array}$ & $\begin{array}{c}\text { Std. Error of } \\
\text { the Estimate }\end{array}$ \\
\hline 1 & $.406^{\mathrm{a}}$ & .165 & .121 & .05499 \\
\hline \multicolumn{7}{|l}{ a. Predictors: (Constant), EPS 2012 } \\
\hline
\end{tabular}

Table 3: Statistical relationship between $\mathrm{CO}_{2}$ emissions (CO2/GDP as of 2017) and EPS index as of 2012, analysed in SPSS

Source: The author

Thus, there arises the question: if environmental policy measures do not explain differing environmental performance among developed countries, what factors does it depend on?

My assumption is that economic and political institutions do matter and institution stability can have an innovation-promoting effect by affecting market environment in a positive way, entailing market mechanisms. To measure economic and political stability I have prepared a composite indicator with the following factors - indicators prepared by the World Bank - (calculating with 0.2 weight in case of each of them): rule of law, government effectiveness, voice and accountability, regulatory quality, and Doing Business ranks.

\footnotetext{
${ }^{47}$ The OECD EPS index includes market-based policies (taxes, trading schemes, FITs, DRS) and non-market policies (standards, R\&D subsidies).

${ }^{48}$ The involved countries in the analysis: Austria, Belgium, Czech Republic, Denmark, Finland, France, Greece, the Netherlands, Ireland, Poland, Hungary, Great Britain, Germany, Norway, Italy, Portugal, Spain, Switzerland, Sweden, Slovak Republic, Slovenia.
} 
In a statical analysis I wanted to study the relationship between institutional stability and innovation performance for the above-mentioned group of countries. I measured innovation performance by the Global Innovation Ranking. I found that there is a strong correlation between the governance composite indicator and innovation performance (Table 4).

\begin{tabular}{|l|c|c|c|c|}
\hline \multicolumn{5}{|c|}{ Model Summary } \\
\hline Model & $\mathrm{R}$ & R Square & $\begin{array}{c}\text { Adjusted R } \\
\text { Square }\end{array}$ & $\begin{array}{c}\text { Std. Error of } \\
\text { the Estimate }\end{array}$ \\
\hline 1 & $.855^{\mathrm{a}}$ & .731 & .722 & 1.39186 \\
\hline \multicolumn{5}{|l}{ a. Predictors: (Constant), governance } \\
\hline
\end{tabular}

Table 4: Statistical relationship between governance indicators and innovation performance, 2016, analysed in SPSS

Source: The author

On the following figure (Figure 9) we can observe to what extent do Business R\&D activities (relative to GDP PPP) determine environmental performance measured by GHG emissions. We can see that actual data points are in line with the linear regression curve. The correlation between Business R\&D investments and GHG emissions/GDP resulted to be strong $\left(R^{2}=0,7\right)$. That is, higher $R \& D$ performance will result in less GHG emissions.

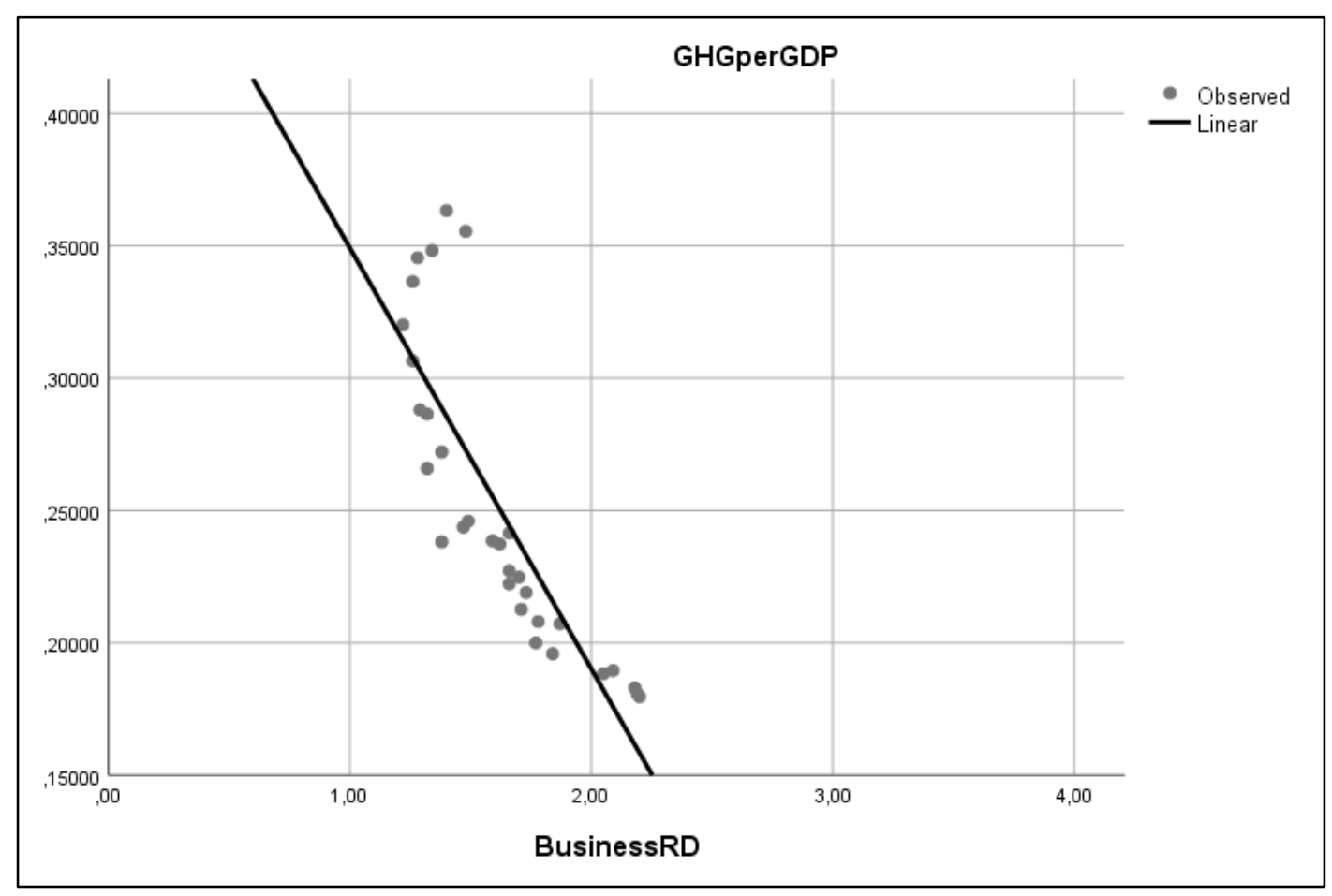

Figure 9: Business R\&D investments and GHG emissions

Source: The author, based on OECD data, analysed in SPSS. 
Empirical analysis shows that there is a strong correlation between innovativeness and environmental performance. Therefore, economic policy measures (not only environmental policy, because it is important to achieve policy synergies when tackling environmental problems) should focus on innovation promotion and fostering low-carbon investments. That means that a proactive policy approach is needed to facilitate economic structural change.

From this perspective, environmental policy stringency, by itself, cannot efficiently face the climate challenge, if it is not embedded in a broader innovation policy which boosts digitalisation, energy efficiency and low-carbon technologies in all sectors, including households. Nevertheless, supportive formal institutions can only achieve their aims if informal institutions also provide a stimulus for clean technology investments.

\section{The European Green Deal will make a change?}

The EU has announced its ambitious strategy of turning climate-neutral by 2050 in 2019 , and in order to do so, a series of sector-specific regulations has been elaborated. The European Green Deal aims at achieving a sustainable green growth; that means, from our perspective, that it would like to offer a solution for the impossible trinity of climate change. The question is: can it tackle the previously analysed efficiency problems?

Some of the most important challenges are the following: the efficient usage of subsidies, the harmonisation of sector-specific regulations in member states and make the European market more integrated.

To be able to guarantee that subsidies reach the desired environmental performance is a very hard task, due to information asymmetry problems and high monitoring costs. The targetmatrix of European subsidies focuses more and more on economic and financial sustainability by introducing market instruments in resource-allocation. We can mention as an example the renewable energy financing mechanism (EU 2020/1294) adopted in September 2020, entered now in the implementation phase. Renewable energy projects will be carried out via Europeanlevel tendering procedures, the EU acting as a mediating body to help investor and target countries find each other, reducing market failures and making the European market more integrated. Member states (as donor countries) can realize their RES (Renewable energy sources) goals by carrying out Renewable Energy investment projects in host member states where RES projects are more cost-efficient, or electricity demand is higher. Therefore, a European-level optimisation can be achieved, and member states are not forced to implement renewable energy projects of low efficiency and subsidies will flow where the allocation is more efficient. At the same time there are various incentives built in the process to foster private 
sector contributions: contributor private entities receive guarantees of origins for the energy produced by its contribution, and all contributions are linked to the Union-wide green label.

Energy integration strategy also shows the same direction: the importance of a more integrated European energy market to be able to reduce transaction costs by establishing energy communities and making energy transformation more efficient. Energy efficiency is a key factor to be able to make economic growth sustainable and to cover energy demand by lowcarbon energy sources. Digitalisation offers many possibilities to enhance energy efficiency, for example by the development of smart grid, better adaptation to energy demand, and by making households more energy-efficient by the application of smart meters.

The European Emission Trading System's 2021 revision also shows the regulatory intention of correcting disfunctions of the ETS system by reducing emissions allowances and by enhanced carbon leakage regulation and a carbon border adjustment mechanism, measures intended to result in a higher carbon price, an approach more suited to internalising the externalities produced by the European Common Market. The current carbon price (around 40 euros/t of $\mathrm{CO}_{2}$ ) approximately represents the efficient carbon price described in various carbon price models, although the disadvantage of cap-and-trade model is the price volatility affecting energy prices for households (WEITZMAN 2017). The new strategy also embraces Nordhaus' view as its scope is to reduce carbon leakages deriving from import (NORDHAUS 2015).

The Recovery and Resilience Facility (RRF) and the Just Transition Mechanism would guarantee that the climate neutral transition be achieved with the least social losses possible, and without ruining sector where climate neutrality is only attainable at high cost (if it is achievable at all).

It is yet very early to assess the efficiency the new European policy measures; however, the experience shows that some obstacles might make it difficult to work. Heterogeneous and inflexible regulatory frameworks may hamper timely adaptation and makes coordination more difficult with higher transaction costs. Member states' national policies, economic development, formal and informal institutions (cultural aspects, mentality, consumers' preferences, corporate culture) and national interests can also differ to a great extent.

According to common pool resources literature in case of a heterogeneous community it is difficult to elaborate and carry out environmental policies that meet all requirements, expectations, and equally effects the welfare function of participants (OSTROM 1990). Consequently, multi-level governance might be a better solution than top-down, centralised regulation. This principle is in line with the EU's subsidiarity principle, too. The enhancement of Member States' cooperation and interconnectedness might contribute to a better European 
environmental performance, although significant differences between European countries will possibly remain, which will decelerate the pace of transition and generate high costs.

EU policies can contribute to make a structural change; however, it is not clear if the efficiency deficits coming with subsidies and market imperfections of the cap-and-trade system can be handled by the new measures. The regulatory framework is not yet completed, and the institutional framework is under development. One of the key elements of this framework is the green taxonomy, which could reduce uncertainties for market actors and policy makers to develop strategies in line with EU policy incentives.

\section{Conclusion}

To conclude the empirical analysis, it has been proven that economic and political institutions play an important role in ensuring a motivating, innovation-promoting market environment for companies. As I have argued, there is a statistical evidence that governmental R\&D policies, subsidies, and negative incentives (taxes, carbon trading schemes) cannot efficiently address the climate challenge, and by itself it cannot ensure better environmental performance.

This can also be a salutary warning for ambitious EU policies like the Roadmap to a lowcarbon economy. As member states have rather different economic and political institutional environments, it is very difficult to harmonise environmental policies at the Community level.

Nevertheless, EU policies targeting energy- and resources efficiency promise to be able to rationalise industrial and household energy performance and the European economy as a whole, by optimising resource-utilisation at a regional level. Digital solutions can contribute to a more competitive energy sector, plus a better, more interconnected organisation of company processes. Technological development and stable institutional environment might enable a more sustainable economic growth.

Currently, and despite considerable policy enhancements, it cannot be stated that the trilemma can be solved in the medium or long term; in the short run it is totally impossible.

Nevertheless, fostering smart technology growth, making market instruments work, and adjusting formal and informal institutions might bring the European economies closer to a more sustainable, low-carbon growth and social well-being. 


\section{References}

ACEMOGLU, D. - AGHION, P. - BURSZTYN, L. - HEMOUS, D. 2012: The Environment and Directed Technical Change. American Economic Review 2012, 102(1) pp.131-166. DOI: 10.1257/aer.102.1.131.

AIZENMAN, J. - CHINN, M. D. - ITO, H. 2013: The "Impossible Trinity" Hypothesis in an Era of Global Imbalances: Measurement and Testing. Review of International Economics, 21(3) pp. 447-458. https://doi.org/10.1111/roie.12047

ARROW, K. 1996: A difficulty in the concept of social welfare. Journal of Political Economy 58, pp. 328-346. https://doi.org/10.1086/256963.

ARROW, K. - BOLIN, B. - COSTANZA, R. - DASGUPTA, P. - FOLKE, C. - HOLLING, C. S. - JANSSON, B.- O. - LEVIN, S. - MALER, K.-G. - PERRINGS, C. - PIMENTEL, D. (2004): Gazdasági növekedés, eltartóképesség és környezet. In: PATAKI Gy. TAKÁCS-SÁNTA A. (szerk.): Természet és gazdaság. Ökológiai közgazdaságtan szöveggyüjtemény. Typotex Kiadó, Budapest, pp. 293-299.

BROCK, W.S. - TAYLOR, M.E. 2010: The Green Solow Model. Journal of Economic Growth, Vol. 15, No. 2 (June 2010), pp. 127-153. https://doi.org/10.1007/s10887-0109051-0.

EUROPEAN COMMISSION. 2008: Guide to cost-benefit analysis of investment projects Available at: https://ec.europa.eu/regional_policy/sources/docgener/guides/cost/guide2008_en.pdf Accessed: 23.05.2019

EUROPEAN COMMISSION. 2020: Commission implementing regulation on the Union renewable energy financing mechanism. Available at: https://eur-lex.europa.eu/legalcontent/EN/TXT/PDF/?uri=CELEX:32020R1294\&from=EN Accessed: 21.12.2020.

FEIERABEND, I. 2011: MITIGATION AND ADAPTATION TO CLIMATE CHANGE. Köz-Gazdaság - Review of Economic Theory and Policy, 6(4), pp. 127-141. Retrieved from http://retp.eu/index.php/retp/article/view/785

FRANKEL, J.A. 2003: THE ENVIRONMENT AND GLOBALIZATION. NBER Working Paper No. w10090, Harvard University - Harvard Kennedy School (HKS). DOI: $10.3386 / \mathrm{w} 10090$.

HÁMORI B. - SZABÓ K. (eds.) 2012: Innováció és verseny, esélyek és korlátok, Aula Kiadó, Budapest 
HAREN P. - SIMCHI-LEVI, D. 2020: How coronavirus could impact the global supply chain by mid-March. Harvard Business Review. 2020; (28 Feb). Available at: https://hbr.org/2020/02/how-coronavirus-could-impact-the-global-supply-chain-by-midmarch. Accessed: 28.02.2021

GEDEON, P. 1992: Demokrácia és piacgazdaság. I. rész: Az iparosodott társadalmak tipológiájához. Közgazdasági Szemle, 39. évf. 5. sz. pp. 401-424.

KARSAI, J. 2007: Kifelé a zsákutcából. Az állami kockázati tőke és innováció. Közgazdasági Szemle, LIV. évf., 2007. december, pp. 1085-1102.

KEREKES, S. - KOBJAKOV, ZS. - MEVÉNÉ SZABAD, K. 1993: A környezetgazdaságtan alapjai, Kereskedelmi, Vendéglátóipari és Idegenforgalmi Főiskola, Budapest

KISS, J. 2005: A magyar vállalatok innovációs tevékenysége. BCE Versenyképesség Kutatóközpont, Versenyben a világgal 2004-2006. Mühelytanulmány

KISS, J. 2009: A magyar innovációs rendszer vállalati nézőpontból, műhelytanulmány BCE Versenyképesség KutatóKözpont

KISS, K. 2011: Rise and Fall of the Concept Sustainability. Journal of Environmental Sustainability, Vol. 1. No. 1.pp. 1-12. DOI: 10.14448/jes.01.0001.

KOCSIS, T. 2010: „Hajózni muszáj!” A GDP, az ökológiai lábnyom és a szubjektív jóllét stratégiai összefüggései. Közgazdasági Szemle, 57. évf. 6. sz. pp. 536-554.

LÓPEZ-FELDMAN, A. - CHÁVEZ, C. - VÉLEZ, M.A. - BEJARANO, H. - CHIMELI, A. B. - FÉRES, J. - ROBALINO, J. - SALCEDO, R. - VITERI, C. 2020: Environmental Impacts and Policy Responses to Covid-19: A View from Latin America. Environ Resource Econ. https://doi.org/10.1007/s10640-020-00460-X.

MAGAS, I. 2018: A pénzügyi alkalmazkodás kis, nyitott gazdaságokban a ,lehetetlen szentháromság” trilemma tükrében. Hitelintézeti Szemle, 17. évf. 1. szám, 2018. március, pp. 5-33.

NORDHAUS, W. 2015: Climate Clubs: Overcoming Free-riding in International Climate Policy. American Economic Review 2015, 105(4) pp. 1339-1370. DOI: 10.1257/aer.15000001.

OECD. 2020: From containment to recovery: Environmental responses to the Covid 19 pandemic, Available at: $\quad$ https://read.oecd-ilibrary.org/view/?ref=126_126460$\underline{1 \text { tg1r2aowf\&title=From-containment-to-recovery_Environmental-responses-to-the- }}$ COVID-19-pandemic. Accessed: 08.25.2020.

OSTROM, E. 1990: Governing the Commons: The Evolution of Institutions for Collective Action New York: Cambridge University Press 
RAWLS, J. 1982: Social unity and primary goods. In A. Sen \& B. Williams (szerk), Utilitarianism and Beyond. Cambridge: Cambridge University Press. pp. 159-186. doi:10.1017/CBO9780511611964.010.

SEN, A. K. 2003: A fejlődés mint szabadság. Európa Kiadó, Budapest.

SOLOW, R. M. 2008: The Economics of Resources or the Resources of Economics. Journal of Natural Resources Policy Research, 1:1, pp. 69-82. https://doi.org/10.1080/19390450802504048.

STERN, D. I. 2004: The Rise and Fall of the Environmental Kuznets Curve. World Development, $\quad$ Vol. $32 . \quad$ No. $8 . \quad$ pp. 1419-1439. https://doi.org/10.1016/j.worlddev.2004.03.004.

WANG, Q. - SU, M. 2020: A preliminary assessment of the impact of COVID-19 on enviroment-A case study of China, Science of the Total Environment 728 (2020) p. 138915. DOI: $10.1016 /$ j.scitotenv.2020.138915.

WEITZMAN, M.L. 2017: On a World Climate Assembly and the Social Cost of Carbon. Economica (2017) 84, pp. 559-586. https://doi.org/10.1111/ecca.12248. 


\title{
Bös-Nagymaros, the Political Taboo of Hydroenergy Gábor László PORHAJAS ${ }^{49}$ - Bence Álmos KISS ${ }^{50}$
}

\begin{abstract}
The implementation of the Bös-Nagymaros dam system has been the subject of a long series of publicpolitical debates, which, even from the perspective of 30 years, can fuel heated discussions over the use of hydro energy. The dam has always played an important political role; in the 1980s, for the Hungarian green movements, which were just unfolding their wings and searching for their political identity.

In our research, we examine how the case of Bös-Nagymaros made the possibility of utilizing hydropower a taboo in the debates on sustainable energy in Hungary. The hypothesis of our research is that the possibility of utilization of hydropower by Bös-Nagymaros has become a political issue as a consequence of assumptions, presumptions, and half-truths instead of a professional-political issue. The arc of this is outlined in our research with the methodology of discourse analysis.

In our analysis, we show how a fundamentally sustainability-energy issue becomes a victim of everyday political debates, determining the possibility of using hydropower for many decades. We hope that, with our research we can contribute to the role of hydropower in Hungary in the discourse related to sustainability, which is becoming more and more powerful.

In the course of our analysis, we discussed the issue of the Bös-Nagymaros dam in a political and geopolitical dimension, during which we tried to grasp the centuries-old dimensions of the discourse at its roots. In this, the dam takes on the character of a political or social enemy, in which conflicts of power (political), economic, cultural, social and background generate layers of discourse. These real or unreal or exaggerated notions of danger and harm form specific social connotations that can thematize thinking, professional, and public discourse on a given issue for decades or centuries.
\end{abstract}

Keywords: Bős-Nagymaros; renewable energy; water dam; Slovakian-Hungarian relationship

\section{Introduction}

The implementation of the Bős-Nagymaros dam system has been the subject of a long series of public-political debates, which, even from the perspective of 30 years, can fuel heated discussions over the use of hydro energy. The dam has always played an important political role; in the 1980s, for the Hungarian green movements, which were just unfolding their wings and searching for their political identity. There are many examples in history where a particular project or investment has become symbolic, with a long-term impact on broader professional and policy issues and thinking, such as the Aswan Dam in Egypt or the never opened Zwentendorf an der Donau nuclear power plant in neighbouring Austria.

Despite the fact that hydropower is considered one of the oldest energy sources, hydropower in Hungary accounts for a very small share of the country's total energy mix (VARGA 2007). Nevertheless, the country's hydropower potential is significant, and it is no coincidence that the construction of large-scale hydropower capacity along the Danube - and to a lesser extent - the Tisza has been on the agenda for decades. In the following paper, we

\footnotetext{
${ }^{49}$ Corvinus University of Budapest, Doctoral School of International Relations and Political Science, PhD Student, porhajasgaborlaszlo@gmail.com

${ }^{50}$ Corvinus University of Budapest, Doctoral School of International Relations and Political Science, PhD Student, kissbencealmos@gmail.com
} 
look at the best known and most over-interpreted, politicised domestic investment; the BösNagymaros dam system, its political construction of meaning and its significant impact on policy thinking, outlined through the history of the construction of the dams.

\section{History of the Bős-Nagymaros Dam System}

The idea of the Gabcikovo-Nagymaros dam system has a very long history. (In our study, we will use the Hungarian name "Bös-Nagymaros" as we consider the two settlements as a symbolic political concept and not as a geographical name. It is important to note that while in the 1990s the term "Gabcikovo-Nagymaros" was used with preference in Hungarian professional writings and newspaper articles, today it has completely disappeared from the discourse.) As a direct antecedent, we can evaluate at the beginning of the 20th century, the idea arose that a dam system should be established on the Mosoni-Danube. The Treaty of Trianon also blocked this planning process. Substantial progress was made in the construction of the dam system in 1956 when the Council for Mutual Economic Assistance (COMECON) decided to examine the possibilities of using the Danube for energy purposes. It was agreed between Hungary and Czechoslovakia as early as 1963 that a joint investment program would be drawn up, but the final investment program, approved by a government decision by both parties, was only adopted in 1974 (based on MÁDL 1992). Subsequently, on 16 September 1977, an international agreement on the implementation and operation of the Bös-Nagymaros Dam system was concluded between the Hungarian People's Republic and the Czechoslovak Socialist Republic, promulgated in Hungary by Act No. 17 of 1978 (Legislative Decree) (BODNÁR 2000).

According to the approved contracts, the purpose of the investment is the complex energy utilization of the affected Danube section; In Hungary, the Dunakiliti dam, a smaller part of the reservoir and the Nagymaros dam would have been built (based MÁDL 1992). The signed interstate treaty put Hungary on a forced track, the construction of the Bös-Nagymaros dam began. The deadline for completion was set by 1990 in the interstate treaty. It is important to note that the investment was initially supported by both the water management and energy, and even a large part of the geographical profession (HAJDÚ 1999).

A few years after the signing of the intergovernmental agreement, both the Czechoslovak and Hungarian economies found themselves in a difficult situation (one of the main reasons for this was the 1979-1980 oil crisis - the price explosion). Its deadline is extended by 5 years, so it is amended to 1995 (based on MÁDL 1992). In order to accelerate the investment, both 
technically and economically, Hungary took out an Austrian bank loan and entrusted much of the construction to Austrian Donauwerke AG, which has an extensive experience in the field of hydropower construction (BRAUN 2014).

With the involvement of Donauwerke AG, the investment clearly intensified, so in the organization of the environmental movements that had already been organized in Hungary, a fierce social protest against the Bős-Nagymaros dam project began to unfold (based on MÁDL 1992).

\section{Protests Against the Bős-Nagymaros Dam Project}

By the early 1980s, there was a growing debate in professional, scientific, and social circles as to whether the Bös-Nagymaros hydropower plant investment could cause serious environmental damage. Biologist János Vargha took the lead in this whole emerging protest professional block and started organizing professional discussions in the student clubs of several universities and colleges in Budapest, to which the experts of the National Water Office (Országos Vízügyi Hivatal - OVH) were regularly invited. According to many, fearing the failure of the discussions with János Vargha, OVH withdrew from the requests after a while and ordered a briefing in 1984 regarding the entire dam investment (FLEISCHER 1992). It is also important to mention that the foundations of these protest groups in Hungary in the early 1980s could be laid by a network of new social movements in the capital and some larger rural towns (SZABÓ 1988).

In 1984, social protests reached such a level that the Danube movement, which protested the investment, submitted a petition of 10,000 signatures to the Government of the Hungarian People's Republic demanding the immediate cessation of the Bös-Nagymaros dam project (FLEISCHER 1992). The Danube Movement was an organization uniting regional and national civil movements protesting dam construction, the best-known "member" of which was the Danube Circle, which organized János Vargha and several other experts around him. The Danube Circle was a so-called transitory team, denoting the type of social movement in which it is typically created by intellectuals with fewer but more enthusiastic and relatively large amounts of leisure time in order to organize a wider social protest (SZABÓ 1988). Thanks to the person(ality) of János Vargha, the Danube Circle was able to gain international recognition quickly. One of the most memorable moments was when in 1985 the organization received the Right Livelihood Award, also known as the alternative Nobel Prize (FLEISCHER 1992). 
The circle of protesters against the Danube circle and the Gabcikovo-Nagymaros dam system far outnumbered ecologically minded, environmentally friendly citizens. This was mainly due to the fact that the protest against the Gabcikovo-Nagymaros dam system soon outgrew itself, as the case essentially advanced into a protest against the ruling elite and institutions of the entire Kádár regime, making it suitable for a very wide range of social mobilization. That the case of the dam system was apt to articulate the conflict between the political regime and society (SZABÓ 1999).

As a sign of the softening of the political system, in 1988 it was already possible to hold open demonstrations without the participants or organizers being subjected to more serious police actions. Taking advantage of this, the Danube Circle organized several extremely successful demonstrations in the autumn of 1988. According to the reports of Népszabadság, 20-25 thousand people took part in the demonstration on Vörösmarty Square on September 12, 1988, and a few weeks later they managed to organize a demonstration at Kossuth Square, which moved 30,000 people. It is important to emphasize, however, that this extraordinary interest was no longer primarily about the case, these demonstrations were assessed by the participants as an anti-regime movement, the reports of contemporary newspapers also e.g., in connection with the demonstration on 12 September, the Magyar Nemzet emphasized that the rhymes most often heard at the demonstration demanded democracy.

The petition, which was handed over to the President of the Hungarian Parliament in February 1989 and demanded the holding of a referendum, and which was signed by 140,000 people, brought the result to the Hungarian Parliament, and put the issue of the dam system on the agenda. Finally, on 13 May 1989, the prime minister Miklós Németh decided to suspend the investment.

With this step, the issue of the dam system seemed resolved to the Hungarian public, but in reality, it caused a great deal of foreign policy tension between Slovakia and Hungary, which were just now seeking independence. The debates around the dam system reached such a level by 1993 that it was already impossible to resolve the issue at the Hungarian-Slovak interstate level. Thus, in 1993, the governments of the Slovak Republic and the Republic of Hungary appealed to the International Court of Justice in The Hague. The International Court of Justice had to rule on such important issues as whether the Republic of Hungary had the right to unilaterally terminate the 1977 interstate treaty, not to build the power plant, and whether Czechoslovakia and the successor Slovak Republic had the right to operate the Gabcikovo power plant and divert the Danube at Cunovo. 
The dispute was closed by the 1997 "Solomon" decision of the International Court of Justice, which ruled that Hungary had unilaterally terminated the 1976 interstate treaty, while the Slovak Republic had unlawfully diverted the Danube from Cunovo (NAGY 2014).

\section{Bős-Nagymaros as a Political Enemy}

In this case, Bős-Nagymaros appears as a moral and political enemy image, but these two characteristics cannot be separated (based on HORUCZI 1993). Moral enemy, which, on the one hand emphasizes the destruction of the environment, the destruction of natural life and its socio-economic consequences and on the other hand a political issue, that symbolized the future to be avoided and transcended as a violent, exaggerated, symbolic project on the brink of regime change. If the typification is carried out according to another aspect, the dam is both an external and an internal enemy - the Czechoslovak state's intervention in the Hungarian environment and the destructive activity of the Hungarian state - potential and current - as a horror of implementation - and similar party-political, ideologically based, all of which are the result of active actions and communication processes. It is abstract in this quality that narrows the protection of the environment, the values to be preserved for the future, into the specific dam project (based on SZABÓ 2006).

In this, stereotyping and generalization - in the case of Hungary, the utilization of hydropower and the essence of Bős-Nagymaros - the establishment of various professional and social oppositions - artificiality and organicity, naturalness or destruction, efficiency - and the emotion where regime change its two sides, the overcoming of the world of state party plans and the petrified planned economy, and last but not least, the system-critical movements are at the centre of the discourse. simplification, personalization, and bipolarization simultaneously appear in the dam as a political enemy, simultaneously forming a framework for cognitive structures related to the dam and hydropower (based on EDELMAN 1998).

The enlightenment techniques highlighted above have also become active shapers of political communication, channelling the direction of public discourse, diverting professional discourse where the problem of the political enemy depends on the political system as an environment, which can first stigmatize and then taboo the initiative, and later, policy decisions in the long run, as a result of which the issue is identified with a kind of pars pro toto argument, thus being treated together with the whole thematic discourse (SZABÓ et al. 2000).

After the change of regime, the depressing issues of Bős-Nagymaros were not resolved even after the lawsuits in the Hague, and to this day they are part of the professional and social 
discourse and heated debates on hydropower, land use and ecology. It took place within the framework of its social and opposition movements related to the dam, and in the framework of this it became an identity-forming and self-organizing force, in a word, "each concrete cube is a symbol" (DURAY 1987). However, the dam is far beyond our northern neighbour itself, as the first major, symbolic project of the newly independent republic in the early 1990s, so its political leaders consider it a matter of prestige. Finally, it should be noted that the process of politicization was coded into its system from the beginning; as János Vargha sums up „... the Danube dam system is a structure that its dreamers and beneficiaries could hardly have built without the conscious use and exploitation of the political implications of the investment and the Soviet-type political system, then the political overtones will appear" (VARGHA 1997, p. 221 ; translated by the authors).

\section{Bős-Nagymaros as a Geopolitical Issue}

Based on the excellent source analysis of János VARGHA, the politicization of the dam was in the initiative from the very beginning, the far-reaching effects of which are still present in both political and professional discourse. Many believe that the movements organized to protect the Danube play a significant role in promoting regime change in Hungary, while in Slovakia the barrier is seen as a matter of prestige, in which, among other things, the direct involvement of the Hungarian minority plays a role. On the third hand, the European Commission, acting as a mediator between the two parties, set as a norm for the acceding countries that Hungary and Slovakia used the International Court of Justice in The Hague to resolve the conflict between them, noting that Hungary's argument building on its rules, it has failed to draw attention to one of the newest and most dynamically evolving areas of international law (based on VARGHA 1997; SZTANCS 2008). However, in a diplomatic matter that spans government cycles and political systems, neither party has actually been able to take meaningful action (HORVÁTH 2009; VARGHA 1997).

The issue, which now dates back about a hundred years, has always been fundamentally political-geopolitical. At the beginning of the 20th century, the use of hydropower was closely linked to national politics. As far as it is known, it was believed that the establishment of hydropower plants in areas inhabited by nationalities would facilitate the assimilation processes by creating new centres for the Hungarian population.

As part of this, they wanted to strengthen the Hungarian population in the region by diverting a part of the population of the Great Plain to the north, but the development of the 
Danube waterway from a military point of view also appeared as an important argument during the First World War.

Based on the principle of the unity of socialism, the formerly open geopolitical interests of the Hungarian People's Republic and Czechoslovakia, which came into the bloc from the 1950s, came to the surface, where they assumed the same political character on both sides, completely taking into account the suggestions of working professionals. At the same time, it should be noted that environmental interests at that time still had very little influence on decisions, despite the fact that the case of the Rhine was already floating in the eyes of experts as an example to be avoided. In 1978, the year the Czechoslovakian-Hungarian interstate treaty on the Danube dam system came into force, when Hungarian television presented the film The Dying Rhine, and in 1979, Hungarian experts travelled to the Rhine to study the effects and consequences. Already at this time, the dam became a symbolic investment, in which ecological, but even broader economic aspects were relegated to the background in the centralized decision-making mechanism, which was characterized by the merging of public administration and industrial production. The central planning mechanism has often been extremely unreliable due to scientific constraints and conflicting information, as well as professional lobbying, in which, individual sectors have tried to carve out as much of the resources centrally allocated as possible due to megalomaniacal projects and proximity to power. Its design and construction were activities envied by many within the water profession. On the other hand, Woldemár LÁSZLÓFFY, the renowned hydrologist urged that water management should vigorously develop its relations with all branches of the natural sciences, but at the same time the spatial approach should prevail and examine the interaction of technical facilities and hydrological phenomena within a river basin (VARGHA 1997).

The power balance of each sector was also influenced by subjective considerations. Hydropower parties, for example, have previously been able to successfully refer to the "Great Soviet Hydropower Plants", in which any criticism may have received a higher level of political influence. It had long urged the construction of the Czechoslovak-Hungarian Danube dams in the Danube Commission, and the development of the waterway was primarily in the interest of the Soviet Union, as his ships transported most of the goods on this area of the Danube (VARGHA 1997).

On the other hand, the basic idea that Czechoslovakia should be a Danube state is much older. The Czech national movement argued, among other things, for the unification of the Czech Republic and Slovakia, that this would provide a free path to the sea and connect Czechs surrounded by Germans with Slavic related peoples. The Danube border was a vital issue for 
the Czechoslovak Republic, in which the unilateral claim to the right to exploit hydropower followed the French example, who, after occupying Alsace during the war and thus extending the country's border to the Rhine, demanded all the Rhine's hydropower (VARGHA 1997).

From the Czechoslovak point of view, one of the most important gains was that the diversion of the Danube on the affected section fundamentally changes the nature of the Czechoslovak-Hungarian state border, which, although formally unchanged, essentially does. The Treaty of Trianon designated the Danube Shipping Main Line as the border between the two states on this section. With the construction of the side canal on the designated section of the Danube, the border will not be the main line of navigation of the river, but an irreversible river meandering in the middle of the abandoned riverbed. Thus, the bank of the Danube owned by the Hungarian state will be 31 kilometres shorter, while the section of the river under exclusively Czechoslovak sovereignty will increase by 25 kilometres (VARGHA 1997).

Another political consequence of the side channel is that the Hungarian minority in Slovakia is isolated from the Hungarian border in the affected section, and the economic sustaining power of the countryside decreases due to changing natural conditions, so they legally promote emigration on both sides (based on DURAY 1987). Compared to river hydropower, the construction of a side channel does not provide any significant energy, shipping, or flood protection benefits, but it exacerbates environmental damage and increases river maintenance costs. There were also dedicated Slovak interests in the construction of the dam within the Czechoslovak state, as these huge investments were financed by the federal government, so the Slovak government could have used roughly 40 billion crowns, mainly in the Czech-Moravian part, without the common coffers. that this would appear in the Slovak budget (DURAY 1987).

The use of political arguments also plays an important role in the construction of dams on the common section of the Danube, instead of completing the river regulation previously planned and started and then abandoned, which could have fully met the needs of shipping. Politically indifferent river hydropower plants could never have been accepted by the water sector as opposed to the much more influential energy sector, because in that case the economic assessment would have been decisive.

Political goals related to the construction of the side canal, which are roughly the same age as the Czechoslovak Republic, already played a significant role in the tug-of-war around hydropower plants. 


\section{Long-term Consequences of Bős-Nagymaros}

The unresolved Bős-Nagymaros issue also left its mark on bilateral relations between the independent Slovak Republic and Hungary in the 1990s. One of the reasons for the fundamentally bad relationship was the situation of the Hungarians in Slovakia, and the other was the disputes over the Gabcikovo-Nagymaros dam system (MITROVITS 2013). Although we can now witness the consolidation of Slovak-Hungarian relations, the issue of the dam is still determining the possibilities of utilizing water energy in Hungary. Despite the fact that several of our domestic river sections could be suitable for the construction of smaller power plants, e.g., a power plant could be established at Adony and Fajsz as well, which would be suitable for generating 1TWh / year of electricity individually (MÉSZÁROS 2014).

The biggest obstacle to the construction of hydropower plants in Hungary is still the case of the Nagymaros dam. The Hungarian professional groups are extremely divided on the issue, while the representatives of the water management profession basically believe that the utilization of water energy would be necessary in Hungary, and the Danube would be suitable for this, while environmental circles believe that the dam would cause unacceptable changes. Professional disputes between the two camps seem insoluble, and since the failure of the Gabcikovo-Nagymaros dam system, with the exception of marginal political forces, no one in Hungary has dared to raise the issue of building additional dams. The main reasons for this, in our opinion, are the creation of a strong environmental lobby group who oppose similar investments, the prevention of the construction of the dam has become a symbolic cause of regime change, and the protest against the dam creates strong nostalgic feelings also in part (MÉSZÁROS 2014).

Of course, the resentment of environmentalists is completely understandable, as to date we only have estimates of the damage caused to the flora and fauna of the Szigetköz by the Gabcikovo power plant and the diversion of the Danube at Cunovo. According to research led by Sándor Kerekes at the Corvinus University of Budapest, the value of natural capital in Szigetköz decreased by 800-1300 billion HUF at 1997 prices (KEREKES et al. 1998).

\section{Summary}

In the case of the dam, we can see a multi-layered, active use of symbols, which interweaves both the conflict and the issue of the utilization of hydropower. The clash of economic and social visions with ecological thinking has long thematized the issue of hydropower utilization, which today, once sustainability has come to the forefront, may once 
again be the scene of heated debates. We believe that the issue of the dam was beyond itself in all political eras and as a result, its politicization was coded into it, as in the case of most large investments and international large investments. In the debates around the dam, the issue of hydropower utilization, landscaping, social and national politics, identity policy, military and defence policy, and countless layers of long-term development strategies and interstate cooperation collide in an arena. Most of the time, they shape the issue according to the current public and policy discourse, opening the debate towards the specific character, so we are sure that the issue of the dam will remain with us for a long time to come.

\section{References}

BODNÁR, L. 2000: A nemzetközi szerződések megszünésének kérdései a Nemzetközi Bíróságnak a bős-nagymarosi beruházás ügyében hozott ítéletében. Retrieved from: http://acta.bibl.u-szeged.hu/7043/1/juridpol_058_081-090.pdf (accessed: 07.03.2021)

BRAUN, A. 2014: DRUŽBA PIPELINE - NAGYMAROS DAM - PAKS NUCLEAR POWER PLANT I. Narratives of energy politics in Hungary (1951-2014). Retrieved from: https://www.osaarchivum.org/files/fellowships/visegrad/reports/2013/BRAUN201304.pdf (accessed: 07.03.2021)

DURAY, M. 1987: A bős-nagymarosi vízlépcső nem energetikai, hanem politikai beruházás. Pozsony. Retrieved from: https://felvidek.ma/2017/10/a-bos-nagymarosi-vizlepcso-nemenergetikai-hanem-politikai-beruhazas/ (accessed:16.02.2021)

EDELMAN, M. 1998: Politikai ellenségek konstruálása. In: Szabó Márton (szerk.): Az ellenség neve. Budapest: Jószöveg Mühely Kiadó, pp. 88-123.

EDELMAN, M. 2000: A politika szimbolikus használata. (Ford. Szabó Péter). In: Szabó Márton - Kiss Balázs - Boda Zsolt [szerk.]: Szövegváltozatok a politikára. Nyelv, szimbólum, retorika, diskurzus Szöveggyüjtemény, Nemzeti Tankönyvkiadó, pp. 179_ 192.

FLEISCHER, T. 1992: Cápafogsor a Dunán: A dunai vízlépcső esete. Retrieved from: http://www.vki.hu/ tfleisch/PDF/pdf92/CAPACI92.pdf (accessed: 07.03.2021)

HAJDÚ, Z. 1999: A magyarországi vízi energia hasznosításának száz éve Csernahévíztől a BNV-ig 1878-1977. Retrieved from: https://epa.oszk.hu/00700/00775/00008/1999_08_07.html (accessed: 07.03.2021)

HORUCZI, L. 1993: Ellenségkép. Az ellenség fogalom történeti alakulása vallásban, morálban, politikában/Az etikaoktatás kiegészítő anyaga. Budapest. 
HORVÁTH, N. 2009: Politikai vizeken - Határvizi diplomáciai esetek. In: GLED, V. (szerk.): Vízkonfliktusok - Küzdelem egy pohár vízért. Pécs: Publikon Kiadó, pp. 239-257.

KEREKES, S. - KINDLER, J. - BARANYI, Á. - BISZTRICZKY, J. - CSUTORA, M. KÉK, M. - KOVÁCS, E. - KULIFAI, J. - NEMCSICSNÉ ZSÓKA, Á. - PÁL, G. SZABÓ, L: - SZERÉNYI, ZS. 1998: A szigetközi térség természeti tőke értékváltozása.

Retrieved from: http://unipub.lib.unicorvinus.hu/3472/1/BNVNEW4.pdf?fbclid=IwAR3VDK25V8DTx13ZDgGYLacI4gFF W_GFQwlT-f8E gtLbCZv0ounfzh5KY (accessed: 07.03.2021)

MÁDL, F. 1992: A Bős-Nagymarosi vízlépcsőrendszer története. Magyar Szemle Új Folyam $\mathrm{I} / 1$.

MÉSZÁROS, Cs. 2014: A vízenergia hasznosítás hazai lehetőségei és korlátozó tényezői Retrieved from: http://www.matud.iif.hu/2014/07/04.htm (accessed: 07.03.2021)

MITROVITS, M. 2013: Csehszlovákia felbomlása és a magyar politika. Múltunk, 2013/1, pp. 148-176.

NAGY, Zs. 2014: Constructs of a conflict. Spatial interpretations of the Bös case. Tér és Társadalom, XXVIII/1, pp. 62-83.

SZABÓ, M. 1988: Vannak-e alternatív társadalmi mozgalmak Magyarországon.In: SÓLYOM, L. - SZABÓ, M.: A zöld hullám. Budapest, Eötvös Loránd Tudományegyetem Állam- és Jogtudományi Kar, pp. 9-31.

SZABÓ, M. 1999: A zöld mozgalmak és polgári kezdeményezések Magyarországon: kutatási problémák, módszertan, elmélet. In: SZABÓ, M.: Környezetvédelmi civil kezdeményezések Magyarországon. Budapest: Villányi úti Konferenciaközpont és Szabadegyetem Alapítvány. pp. 15-59.

SZABÓ, M. 2006: Politikai idegen. A politika diszkurzív szereplőinek elméleti értelmezése. L'Harmattan, Budapest

SZTANCS, E. 2008: 15 éve már - gondolatok a bős-nagymarosi vízlépcsőperről. Debreceni Jogi Mühely, 2008. 5/2.

VARGHA, J. 1997: Vízerő és politika. In: VARGHA, J. (szerk.): A hágai döntés. Budapest: Enciklopédia Kiadó, pp. 221-287.

VARGA, K. 2007: Fenntarthatóság a megújulók hasznosításában. Energia Klub memorandum no. 4. Retrieved from: https://energiaklub.hu/dl/kiadvanyok/Energia_Klub_memorandum_fenntarthatosag_meg ujulok_hasznositasaban.pdf (accessed: 05.01.2021) 


\title{
Expanding ecological rights and the effective dimension of political rhetoric

\author{
Csendike SOMOGYVÁRI ${ }^{51}$
}

\begin{abstract}
Ecological inequality encompasses such matters as accessible fresh air, potable water, clean living spaces, and exposure to sunlight. In many places around the world, people, especially from lower income strata, are dying as a result of critical air pollution or working in physically dangerous, toxic environments. Introducing equal ecological rights is closely related to a better and more sustainable future. This paper seeks to answer the question of how expanding equal ecological rights may contribute to the efficacy of political rhetoric. In order to explore this question, the article presents a brief narrative review on the concept of performativity and ecological rights. Drawing upon Pierre Bourdieu's theory on social inequality and symbolic violence, the paper presents a case study of the US Presidential Election of 2020 by analyzing statements related to ecological inequality of Presidential Candidate Joe Biden and President Donald Trump during the campaign period. The proposed methodology combines performance and discourse analysis with multimedia usage.
\end{abstract}

Keywords: ecological inequality, political campaigns, performativity, sustainability

\section{Introduction}

As a result of global warming and overpopulation, the dilemma of a sustainable future is becoming an increasingly burning issue today. Narrative interpretations of what shall be considered as an effective socio-political action towards achieving this goal are heavily influencing our understanding of reality. In the second half of the twentieth century, language came into the spotlight as the Holy Grail of defining major crises such as social inequalities or state failures as many notable scholars from Emile Durkheim, Ferdinand de Saussure to Michael Foucault developed their own theories on linguistic structures and social relations. By the end of the century, the ultimate power of linguistic inventions has been called into question and the concept of performativity received an increasing attention. According to the interpretation of Karen BARAD (2003, p. 802) "a performative understanding of discursive practices challenges the representationalist belief in the power of words to represent preexisting things. Performativity, properly construed, is not an invitation to turn everything (including material bodies) into words; on the contrary, performativity is precisely a contestation of the excessive power granted to language to determine what is real."

The performative turn as a paradigmatic shift in the humanities and social sciences had a tremendous impact on such disciplines as linguistics, cultural studies, anthropology, ethnography, sociology, political science, and the relatively new discipline of performance studies. The concept of performativity infiltrated into complex theories in the post-modern era,

\footnotetext{
${ }^{51}$ Corvinus University of Budapest, Doctoral School of International Relations and Political Science, PhD student csendikesomogyvari@gmail.com
} 
based on the idea of what we should call a performance. The concept is ultimately summoned to explain dynamic relations between social actors and their direct environment.

Performance has two distinguished meanings that need to be taken into consideration: on the one hand, it is realized as an enactment out of conventional actions of daily life; and on the other hand, it could also be considered as a formal, public event which brings the meaning of public sphere into the discourse. In The Human Conditions, Hannah Arendt realizes public sphere as a space where different beings relate to each other and build up a common reality by speaking, and most importantly, by acting. Arendt has been inspired by the Aristotelian interpretation of public space and her theory of action revolved around distinguishing action (praxis) from fabrication. According to Arendt, the meaning of action is the articulation retrospectively given by narrators (ARENDT 1958). Following Pierre Bourdieu's theory, these narratives are often interpreted by individuals in a dominant position who aim to impose their own cultural and symbolic products on the rest of society, thus playing a central role in the reproduction of the existing power relations (BOURDIEU 1989; CATTANI et al. 2014). Likewise Arendt, Bourdieu also relies on his own interpretation about the theory of action, which is based on the concept of "habitus," defined as a socially constituted system of dispositions that orient "thoughts, perceptions, expressions, and actions" (BOURDIEU 1989).

The concept of sustainability is a combination of ecological, economic, social, and institutional aspects of social development. Ecological inequality encompasses such matters as accessible fresh air, potable water, clean living spaces, and exposure to sunlight. In many places, people, especially from lower income strata, are dying as a result of critical air pollution or working in physically dangerous, toxic environments. Introducing equal ecological rights is closely related to a better and more sustainable future. This paper begins with the following observation: sustainability itself can be realized as a performative practice, thus the actions behind the words play a major role in interpreting the challenges we face.

The paper is divided into four sections, including the introduction and conclusion. As the goal of this paper, I intend to reflect on the question how expanding equal ecological rights may contribute to political rhetoric. In order to explore this question, in the first section of the paper, I am proposing a brief narrative review on the concept of performativity and ecological rights. My aim is to highlight that despite becoming an increasingly important factor in the context of social development, thus playing a gradually important role in today's political discourse, providing equal ecological rights are still reduced to empty promises in the absence of meaningful actions - even though at least these so-called empty words can create attention to the problem. In the second section of the paper, drawing upon Pierre Bourdieu's theory on 
social inequality and symbolic violence, I present a case study on the US Presidential Election of 2020 by analyzing statements related to ecological inequality of Presidential Candidate Joe Biden and President Donald Trump during the campaign period of 2020. The proposed methodology combines performance and discourse analysis with multimedia usage. In response to Bourdieu's theory that claims, naturalized inequalities cannot be seen as problems to be solved, but as obvious facts of everyday life (KOOPMANS - DUYVENDAK 1995); I argue that advocating change on behalf of the dominated group is the only sufficient way to denaturalize social inequalities; but in special situations of the political sphere, such as for example in election campaign periods, the denaturalization of naturalized social inequalities can take place through the representations of actions by the actual dominant group who control the system in order to get as many votes as possible. Thus, these members of the dominant group, even if only temporarily, may advertise narratives that can lead to denaturalizing existing social inequalities. The accepted social order -although under external pressure, which in this case is the maximalization of votes- is ultimately shaped according to the interest of the dominant group in such a way that it can be favorable to the dominated group as well.

Being aware of the complexity of this issue, the research has its own limitations. Using critical performativity in establishing social theories may disregard the fact that even though performativity and performance are both based on the word "to perform" which could be interpreted as "to act", the two concepts are not the same. Performativity in social sciences relies heavily on linguistic explanations of the term, ignoring major characteristics of the theatrical performance itself. However, theatricalization of politics provides not only potential for understanding power relations and inequalities of the public sphere but also subjectivity concerning the question. As for the case study used in the research, due to the size requirements of the research, I do not have the capacity to reflect on the whole pool of political statements related to the environmental inequality, therefore this aspect of the research also carries with it the possibility of subjectivity. Reflecting on Bourdieu's theory, one cannot ignore the distinction between fabrication and action of the Arendtian philosophy. What is said in a political campaign, and what is realized from what has been said, therefore to what extent the actual denaturalization of social inequality could be measured in practice, requires further research.

\section{Performativity and environmental inequality}

In this section I intend to present why action matters in resolving such social issues as environmental inequality. The concept of performativity is feeding from the power of language 
to effect change in the world: language does not simply describe social relations but may function as a form of social action. The concept of performative language was first developed by John L. Austin who suggested that there is a difference between constative language, which describes the relations in the public sphere, and performative language, which creates action in the social realm. For Austin, performative language included speech acts such as promising, swearing, betting, or performing a formal ceremony, signing declarations and so on. Austin claimed that a number of conditions must be met in order for such utterances to function performatively (AUSTIN 1962).

Other notable scholars have redefined these basic insights to explore the various ways in which language can do things in the world. Most notably, Judith Butler developed the concept of performativity to describe how the concept of gender is constructed in the 1990s. Butler stressed out that gender is a socially constructed process, which is based on a number of constant performative acts (BUTLER 1990). Performativity, indeed, is the process of subject creation, which describes and occurs through linguistic means, as well as via other social practices. As a result of Butler's original theory, the concept of performativity has been richly explored in anthropological studies of gender and sexuality and infiltrated into other disciplines as well.

For example, scholars of ritual have also used the concept of performative action and performativity very productively, looking at how rituals work performatively. Resistance studies, that also relies heavily on the importance of action, also became increasingly interested in the concept of performativity. Social performances and practices have been also analyzed from a performative viewpoint. In the late 1990s, many researches were conducted to highlight that economies began to consider economic performativity, or how the practices of economists and other financial experts were not simply descriptive of their subject but also served to shape it. A number of challenges and issues have characterized theoretical debates about performative language and performativity. These include the role of actors' intentions and issues of agency, the importance of context, the iterability or repeated versus spontaneous nature of performative action, and the effects of social roles and distributions of power across participants.

As for environmental studies, for example the concept of performative environmentalism has also gained a significant attention. On one hand, environmental activists use performance to express their pain of living in a polluted region, which can also be connected to the discipline of resistance studies. However, only a limited number of researches have been conducted on performative and performance-based relationships to justice and especially on environmental injustice, despite its great potential (JAMAL - HALES 2016). Performative environmentalism 
also includes a personalized practice on fighting against climate change as it serves to encourage all members of the society individually to act in order to promote a more sustainable future. However, environmental rights which are proclamations of a human right to environmental conditions of a specified quality, are also having performative aspects. Human rights and the environment are merged; human rights cannot be fulfilled without a clean and healthy environment; and sustainable environmental governance cannot exist without the establishment of and respect for human rights. In 1948, the promise itself that was declared through the Universal Declaration of Human Rights was a performative act. However, the performative act of signing the Declaration failed to solve all the issues we are facing today. Without the concrete action even performative acts can be empty words, although, these words can actually help to promote action to become alive through narratives.

\section{Ecological rights and political rhetoric}

Addressing environmental inequalities and injustice played a major role in the 2020 U.S. presidential campaign. As racism and social inequalities gained more media exposure as a result of the movements following the assassination of George Floyd, these issues became hot in shaping the campaign strategy of the two parties. In many US cities, people, especially from lower income strata, are dying as a result of critical air pollution or working in physically dangerous, toxic environments. A predicted $70 \%$ of toxic environments are located in lowincome neighborhoods, and an upwards of 2 million Americans live within a mile of sites that are vulnerable to flooding, and the fact that the majority of these are inhabited by colored communities makes environmental injustice not only an issue of social inequality but an issue of systematic racism. A 2018 study conducted by the EPA showed that at the national, state, and county levels, non-white Americans are disproportionately burdened by particulate matter or air pollution consisting of automobile fumes, smog, soot, oil smoke, ash, and construction dust (COLAROSSI 2020).

In this case study, I have analyzed 15 statements on environmental injustice made by Presidential Candidate Joe Biden and President Donald Trump from July 2020 to October 2020. The transcripts of the speeches and remarks including multimedia materials -such as videos, or social media posts are available on the official archive of the White House and on the multimedia converter site of Rev.com. Since it is a great number of statements, I do not present all the statements in a complete, cursive form, but the table created for this purpose contains a summary of all the texts that were analyzed (see Appendix). I find the most crucial materials to be the actual presidential debates, which are by nature different from pre-written 
speeches and pre-arranged interviews. As opposed to traditional discourse analysis I do not only reflect on what has been said on a textual level, but I divide the analysis into two sections, in the first part I am only concentrating on the textual facts such as 1) during the statement, how many times environmental inequality has been mentioned?; 2.) what is the exact context of environmental inequality in the text?; and 3.) what kind of narrative the text conveyed on the topic? In the second section I am analyzing the actual performative interpretation of the statements by highlighting the dilemma around the question of action and representation. I assume that promoting equal ecological rights do have a positive effect on the efficacy of the political rhetoric and by that has a denaturizing effect on the environmental inequality.

In case of the presidential debates, the first one was moderated by Chris Wallace of Fox News on September 29, 2020 in Cleveland, Ohio. Environmental injustice was mentioned five times explicitly during the discourse, first time at $36: 50$ by Candidate Joe Biden referring to "[President Trump's] His failure to deal with the environment, [suburbs) are being flooded, they're being burned out because his refusal to do anything”. At 48:50, Moderator Wallace brought climate change into question again, addressing President Trump to pull the US out of the Paris Climate Accord, and have rolled back a number of Obama Environmental records. According to President Trump's strategy, he claimed "I want crystal clean water and air. I want beautiful clean air. We have now the lowest carbon... If you look at our numbers right now, we are doing phenomenally. But I haven't destroyed our businesses". In this section, President Trump rather reflected on forest management (50:32), energy prices (51:35), and automotive industry (52:08), while his opponent proposed expanding the opportunities of green jobs (52:34), zero none admission of greenhouse gases (53:03). From 55:39, the fierce tempers of the debaters make it difficult to interpret the text, since both of them are unable to complete their sentences. Until 59:24, the topic was merely about the Green New Deal plan which also generated heavy fights between the candidates. In the final debate moderated by Kristen Welker of NBC News on October 22, 2020 in Nashville, Tennessee, environmental issues appeared seven times explicitly. At 12:41, Moderator Welker addressed the debaters by saying "President Trump, you say that environmental regulations have hurt jobs in the energy sector, Vice President Biden, you have said you see addressing climate change as an opportunity to create new jobs." President Trump reflected on the question by highlighted the Paris Accords that "treated [the US] very unfairly" (13:08), claiming that "[The Trump administration] has done an incredible job environmentally, we have the cleanest air, the cleanest water, and the best carbon emission standards that we've seen in many, many years". (14:03) "And we haven't destroyed our industries". (14:41). Presidential Candidate Biden, on the other hand 
mentioned that "Climate change, global warming is an existential threat to humanity" (14:47) and his plan "will create millions of new good paying jobs" (16:03). President Trump reacted by saying “[Joe Biden's] plan is an economic disaster (16:42). Until 20:59, the debate became as turbulent as the first time, while the topic was still on the environmental issues.

According to the database of Rev. com, from 15 January 2020 to 20 January 2021, by and large, 432 speeches, interviews and statements have been released by party members, candidates and advocates of both the Republican and Democratic party. Out of 432 speeches I only concentrated on those which made by either Presidential Candidate Joe Biden or President Donald Trump. Since I only analyzed speeches from July 2020 to October 2020, made by the two opponents, I experienced a shift from environmental issues to the current COVID-19 pandemic management, which means between the two Presidential Debates, the focus was on the pandemic, and much less on environmental inequalities. As opposed to my initial belief in the analyzed texts, President Donald Trump referred two times higher on environmental issues, however, the context was closely related to the economic aspect of environmentalism, and in many cases the term had a rather negative connotation. President Candidate Joe Biden, on the other hand, made it clear that reflecting on environmental inequality was a great part of his agenda by not only addressing climate change itself, but fighting against environmental injustice with action - introducing the Biden-plan. Since environmentalism has always been more of a left-wing topic, it is not surprising that it has a great importance in the agenda of the Democratic party.

However, these two debates can be analyzed not only in a contextual form, but with the help of performance analysis, we can consider these debates as public, formal events. Therefore, in this context, the performers -President Trump and President Candidate Joe Biden- not only used their speech to create an effect on the viewers. Relying on Austin's theory on performativity, what Austin calls constative utterances, might be such statement as "It's a sunny day," or "I went shopping" which are perlocutionary acts; thus, by saying "I went shopping," I am not doing it, I am merely reporting an occurrence (SALIH 2006). The problem of perlocutionary acts is that language does not carry the actual action, therefore the possibility of change, but rather manifesting as a representation of the action. This sense of representation does not equal to the representationalist belief that language refers to preexisting conditions, but as in the theatrical terminology, it is portraying a certain behavior. Giving the fact that the viewer has their own perceptions about the world in case of a Presidential Debate, likewise in the theater, the viewer will identify with whom they share views. 
For Bourdieu, neo-liberalism is deeply rooted in numerous types of symbolic violence. The moment when the dominant group force their views on the oppressed group to maintain the existing social order, symbolic violence occurs immediately. In his research, Bourdieu's theory did not feed from merely rational action theory. According to Bourdieu, the stability that the habitus communicates with the social world is closely related to the process of naturalization of the public space and of the state of social domination that characterizes it. Therefore, the most prominent part of his research relies on structures. Domination, in Bourdieu's framework, emerges through the obligation of specific subjectivities on objective dispositions, naturalizing social domination and its reproduction. Social denaturalization dissolves the symbolic violence, contributing to the autonomy of social agents. Bourdieu claimed that the reproduction of domination works through many channels, one of them being the emotional aspect of the habitus. The hierarchical order of the society and its boundaries are partly grounded in bodily emotions, including shame, humiliation, timidity, anxiety and guilt (BOURDIEU 1984). In this sense, Bourdieu's theory on body could be easily matched to Judith Butler's performativity.

I argue that advocating change on behalf of the dominated group is the only sufficient way to denaturalize social inequalities; but in special situations of the political sphere, such as for example in election campaign periods, the denaturalization of naturalized social inequalities can take place through the representation of actions by the actual dominant group who control the system in order to get as many votes as possible. Thus, representatives of the dominant group, even if only temporarily, may advertise narratives that can lead to denaturalizing existing social inequalities. The accepted social order -although under external pressure, which in this case is the maximalization of votes-is ultimately shaped according to the interest of the dominant group in such a way that it can be favorable to the dominated group as well. According to the case study I have made, the Presidential Debates of 2020, promoting environmental equality and expanding ecological rights, even if it is just a representation of action, has denaturalizing effects on environmental inequality, since it builds a narrative around the issue. The way of naturalizing social inequality is to be silent about it. However, the concept of performativity operates with real action, even the flawed representation of the action could be sufficient to create a narrative that draws attention to the seriousness of the problem and thus can lead to the real action that denaturalizes social inequality. Although, it is important to mention that the use of Bourdieu's symbolic violence could also be excellently illustrated in the case study outlined, as both debaters stressed the need to maintain the existing economic order, which, however, does not bridge the gap between real social inequalities. As for my pre- 
existing research question of how expanding ecological rights may contribute to the efficacy of political rhetoric was well demonstrated by this case study as during the campaign period and especially in the two Presidential Debates the discourse on environmental inequalities not only was significant, but according to many analysis one of the most important factors during the election campaign period which shifted towards the COVID-19 crisis management during the final months of the campaign.

\section{Conclusion}

The goal of this paper was to reflect on the question how expanding equal ecological rights may contribute to political rhetoric. In order to explore this question, in the first section of the paper, I proposed a brief narrative review on the concept of performativity and ecological rights. My aim was to highlight that despite becoming an increasingly important factor in the context of social development, thus playing a gradually important role in today's political discourse, providing equal ecological rights is still reduced to empty promises in the absence of meaningful actions. The concept of performativity is feeding from the power of language to effect change in the world: language does not simply describe social relations but may function as a form of social action.

In the second section of the paper, drawing upon Pierre Bourdieu's theory on social inequality and symbolic violence, I present a case study on the US Presidential Election of 2020 by analyzing statements related to ecological inequality of Presidential Candidate Joe Biden and President Donald Trump during the campaign period of 2020. The proposed methodology combines performance and discourse analysis with multimedia usage. In response to Bourdieu's theory that claims, naturalized inequalities cannot be seen as problems to be solved, but as obvious facts of everyday life (KOOPMANS - DUYVENDAK 1995) I argued that advocating change on behalf of the dominated group is the only sufficient way to denaturalize social inequalities; but in special situations of the political sphere, such as for example in election campaign periods, the denaturalization of naturalized social inequalities can take place through the representations of actions by actual dominant group who control the system in order to get as many votes as possible. Thus, representatives of the dominant group, even if only temporarily, may advertise narratives that can lead to denaturalizing existing social inequalities. The accepted social order -although under external pressure, which in this case is the maximalization of votes- is ultimately shaped according to the interest of the dominant group in such a way that it can be favorable to the dominated group as well. 
In this case study, I have analyzed 15 statements on environmental injustice made by Presidential Candidate Joe Biden and President Donald Trump from July 2020 to October 2020. The transcripts of the speeches and remarks including multimedia materials -such as videos, or social media posts are available on the official archive of the White House and on the multimedia converter site of Rev.com. According to the database of Rev. com, from 15 January 2020 to 20 January 2021, by and large, 432 speeches, interviews and statements have been released by party members, candidates and advocates of both the Republican and Democratic party. Out of 432 speeches I only concentrated on those which were made by either Presidential Candidate Joe Biden or President Donald Trump.

Since I only analyzed speeches from July 2020 to October 2020, made by the two opponents, I experienced a shift from environmental issues to the current COVID-19 pandemic management, which means between the two Presidential Debates, the focus was rather on the pandemic, and much less on environmental inequalities. As opposed to my initial belief in the analyzed texts, President Donald Trump referred two times higher on environmental issues, however, the context was closely related to the economic aspect of environmentalism, and in many cases the term had a rather negative connotation. President Candidate Joe Biden, on the other hand, made it clear that reflecting on environmental inequality is a great part of his agenda by not only addressing climate change itself, but fighting against environmental injustice with action - introducing the Biden-plan. However, these two debates can be analyzed not only in a contextual form, but with the help of performance analysis, we can consider these debates as public, formal events. Therefore, in this context, the performers -President Trump and President Candidate Joe Biden- not only used their speech to create an effect on the viewers. Referring to Bourdieu's theory on symbolic violence, according to the case study I have made, the Presidential Debates of 2020, promoting environmental equality and expanding ecological rights, even if it is just a representation of action, has denaturalizing effects on environmental inequality, since it builds a narrative around the issue. The way of naturalizing social inequality is to be silent about it. However, the concept of performativity operates with real action, even the flawed representation of the action could be sufficient to create a narrative that draws attention to the seriousness of the problem and thus can lead to the real action that denaturalize social inequality. Although, it is important to mention that the use of Bourdieu's symbolic violence could also be excellently illustrated in the case study outlined, as both debaters stressed the need to maintain the existing economic order, which, however, does not bridge the gap between real social inequalities. 


\section{References}

ARENDT, H. 1985: The Human Conditions. Chicago: University of Chicago Press.

AUSTIN, J. L. 1962: How to Do Things with Words. Cambridge, Mass.: Harvard University Press.

BARAD, K. 2003: Posthumanist Performativity: Toward an Understanding of How Matter Comes to Matter - Gender and Science: New Issues 28 (3): pp 801-831. https://doi.org/10.1086/345321.

BUTLER, J. 1999: Gender trouble: feminism and the subversion of identity. New York: Routledge.

BOURDIEU P. 1984: Distinction. Cambridge Mass: Harvard UP.

BOURDIEU, P. - WACQUANT, L. 2000: Neoliberal Newspeak: Notes on the new planetary vulgate. Radical Philosophy 108. (Jan): pp. 1-6.

BOURDIEU, P. et al 2000: Weight of the World: Social Suffering in Contemporary Society. Stanford University Press.

CABANTOUS, L. - GOND J.P. - HARDING, N. - LEARMONTH, M. 2016: Critical essay: Reconsidering critical performativity. Human Relations 69(2), pp. 197-213. https://doi.org/10.1177/0018726715584690.

CATTANI, G. - FERRIANI, S. - ALLISON, P. 2014: - Insiders, Outsiders and the Struggle for Consecration in Cultural Fields: A Core-Periphery Perspective. American Sociological Review 78(3): pp. 417-447.

COLAROSSI, N. 2020: 10 egregious examples of environmental racism in the US. - Insider published online at https://www.insider.com/environmental-racism-examples-unitedstates-2020-8, 11/08/2020 - downloaded 06/03/2020.

CORVELLEC, H. 2016: Sustainability objects as performative definitions of sustainability: The case of food-waste-based biogas and biofertilizers. Journal of Material Culture, 21(3), pp. 383-401.

DALTON, R. - KLINGEMANN, H. D. 2009: The Oxford Handbook of Political Behavior. New York: Oxford University Press Inc.

DERRIDA, J. 1999: Signature Event Context. In: KAMUF, Peggy (ed.) A Derrida Reader: Between the Blinds, New York: Columbia University Press, pp. 80-111.

DIJK, T. A. 2001: Critical Discourse Analysis - Handbook of Discourse Analysis - Blackwell Handbooks in Linguistics. New Jersey: Blackwell Publishers. 
FISCHER-LICHTE, E. 2009: Culture as Performance. Modern Austrian Literature 42 (3): pp. $1-10$.

FRANGIE S. 2009: - Bourdieu's Reflexive Politics Socio-Analysis, Biography and SelfCreation. European Journal of Social Theory 12(2), pp. 213-229.

GEE, J.- HANDFORD, M 2012: The Routledge Handbook of Discourse Analysis. Routledge, Taylor \& Francis Group.

GOODIN, R. - TILLY, C. 2006: The Oxford Handbook of Contextual Political Analysis. New York: Oxford University Press Inc.

GREGSON, N. - ROSE G. 2000: Taking Butler elsewhere: performativities, spatialities and subjectivities. Environment and Planning D: Society and Space, pp. 433 -452.

GRIESSLER, E. - LITTIG, B. 2005: Social sustainability: a catchword between political pragmatism and social theory. International Journal for Sustainable Development, 8(1/2), pp. 65-79.

HABERMAS, J. 1985: The Theory of Communicative Action Volume 2- Lifeworld and System: A Critique of Functionalist Reason. Boston: Beacon Press.

HERAS, M., - TÀBARA, J. D. 2014: Let's play transformations! Performative methods for sustainability. Sustainability Science, 9(3), pp. 379-398.

INGALA, E. 2017: From Hannah Arendt to Judith Butler -The Conditions of the Political Subjectivity and the Political. New York: Routledge.

JAMAL, T. - HALES, R. 2016: Performative justice: New directions in environmental and social justice. Geoforum 76, pp. 176-180.

KOOPMANS, R. - DUYVENDAK, J. 1995: The political construction of the nuclear energy issue and its impact on the mobilisation of anti-nuclear movements in Western Europe. Social Problems 42 (2), pp. 235-51.

MOORE, D. 1997: Remapping resistance: 'ground for struggle' and the politics of place". Geographies of Resistance. London: Routledge, pp. 87 -106.

ROSE, M. 2001: The seductions of resistance: power, politics, and a performative style of systems. Environment and Planning D: Society and Space 20: pp 383-400.

SALIH, S. 2006: On Judith Butler and Performativity - Sexualities and Communication in Everyday Life: A Reader, pp. 55-68. CA: Sage.

SCRIMALI, L. 2009: A variational inequality formulation of the environmental pollution control problem. Optimization Letters, 4(2), pp 259-274.

SHAPIRO, M. 1984: Language and Politics. New York: New York University Press. 
SIM, Y. - ACREE, B. - GROSS, J. - SMITH N. 2013: Measuring Ideological Proportions in Political Speeches. Seattle: Proceedings of the 2013 Conference on Empirical Methods in Natural Language Processing, pp: 91-101.

SMITH, K. 2007: Pierre Bourdieu - Challenging Symbolic Violence and the Naturalisation of Power Relations. - E-International Relations - published online at https://www.eir.info/2007/12/22/pierre-bourdieu---challenging-symbolic-violence-and-thenaturalisation-of-power-relations/, 11/08/2020 - downloaded 06/03/2020.

RINGMAR, E. 2016: How the world stage makes its subjects: an embodied critique of constructivist IR theory. Journal of International Relations and Development 19, pp. 101125 .

WEININGER, E. 2002: Pierre Bourdieu on Social Class and Symbolic Violence. - Alternative Foundations of Class Analysis New York: Routledge.

\section{Appendix}

Summary of all the texts that were analyzed.

\begin{tabular}{|c|c|c|}
\hline Date & Name & $\begin{array}{c}\text { Number of referring directly to } \\
\text { environmental equality }\end{array}$ \\
\hline 2020.07 .14 & Joe Biden Clean Energy Plan Speech Transcript July 14 & 6 \\
\hline 2020.07 .16 & $\begin{array}{l}\text { Donald Trump Speech Transcript on Rolling Back } \\
\text { Environmental Regulations }\end{array}$ & 9 \\
\hline 2020.07 .21 & Donald Trump Tulsa, Oklahoma Rally Speech Transcript & 3 \\
\hline 2020.07 .28 & Joe Biden Racial Equity Plan Speech Transcript July 28 & 2 \\
\hline 2020.08 .06 & $\begin{array}{l}\text { Joe Biden Interview Transcript August 6: Compares Black and } \\
\text { Latino Diversity \& Faces Criticism }\end{array}$ & 1 \\
\hline 2020.08 .17 & Donald Trump Speech Transcript Minnesota August 17 & 4 \\
\hline 2020.08 .21 & Joe Biden 2020 DNC Speech Transcript & 1 \\
\hline 2020.09 .03 & $\begin{array}{l}\text { Donald Trump Latrobe, Pennsylvania Rally Speech Transcript } \\
\text { September } 3\end{array}$ & 1 \\
\hline 2020.09 .08 & $\begin{array}{l}\text { Donald Trump Speech in Jupiter, Florida Transcript } \\
\text { September 8: Environmental Accomplishments }\end{array}$ & 16 \\
\hline 2020.09 .14 & $\begin{array}{l}\text { Joe Biden Climate Change Speech Transcript in Wilmington, } \\
\text { Delaware September } 14\end{array}$ & 5 \\
\hline 2020.09 .16 & $\begin{array}{l}\text { Donald Trump ABC News Town Hall Transcript with George } \\
\text { Stephanopoulos in Philadelphia }\end{array}$ & 1 \\
\hline 2020.09 .20 & $\begin{array}{l}\text { Joe Biden Philadelphia Speech Transcript Sept. 20: Accuses } \\
\text { Trump \& Republicans of Abuse of Power Over SCOTUS }\end{array}$ & 2 \\
\hline 2020.09 .23 & Joe Biden Racial Equity Discussion Transcript September 23 & 1 \\
\hline 2020.09 .29 & $\begin{array}{l}\text { Donald Trump \& Joe Biden 1st Presidential Debate Transcript } \\
2020\end{array}$ & 5 \\
\hline 2020.10 .22 & $\begin{array}{l}\text { Donald Trump \& Joe Biden Final Presidential Debate } \\
\text { Transcript } 2020\end{array}$ & 7 \\
\hline \multicolumn{2}{|c|}{ Environmental issues in Joe Biden's Speeches } & 18 \\
\hline \multicolumn{2}{|c|}{ Environmental issues in Donald Trump's Speeches } & 34 \\
\hline
\end{tabular}

Source: Rev.com 


\section{Chapter III}

International relations in the light of sustainability 


\title{
Indonesia's Foreign Policy in Energy Security Issues Donie KADEWANDANA ${ }^{52}$
}

\begin{abstract}
Energy security is still one of the international security issues and part of countries' foreign policy. Energy sources are considered an important part of national economic growth and global market products and have a very strategic value for the interests of national and international security policies. The purpose of energy security is to secure a country's energy supply and demand. To fulfill this, strategic efforts are needed in dealing with energy problems, both at the national and international levels. The study results show that based on the principle of a free and active foreign policy, the Indonesian government has built international energy partnerships and cooperation through various international forums and institutions. Through these various collaborations, Indonesia has a unique opportunity to take advantage of technology transfer, capacity building, and investment. However, it seems that Indonesia has not optimized all the opportunities that exist. In addition, there is still no institutionalization of international energy security policies at the level of the Indonesian Ministry of Foreign Affairs. Energy security in the international arena is a strategic issue that Indonesia's foreign policy needs to focus on in order to build total diplomacy. It is hoped that the country will no longer depend solely on diplomats' ability in global diplomacy forums. Indonesian citizens and other stakeholders, both at home and abroad, can also contribute to the image of the Indonesian nation in the international arena. By increasing diplomatic activities involving many stakeholders, it is hoped that Indonesia's energy diplomacy efforts will run more effectively and have a wider and more significant impact in the international arena.
\end{abstract}

Keywords: Foreign policy, energy security, energy policy, diplomacy

\section{Introduction}

In recent years, energy security is still one of the national and international problems of countries around the world. Energy sources have a very strategic value in terms of national and international security. Massive industrialization and global population growth require substantial energy resources to operate power plants, various modes of transportation, and industry.

Under these conditions, cooperation between countries in securing energy sources is crucial, especially industrialized countries that are highly dependent on countries that produce energy sources. At the same time, energy dependence also leads to opportunities and risks for competition and conflict between countries in obtaining energy supplies. Therefore, a country's energy security policy should involve diplomacy between countries because energy security in foreign policy emphasizes strategic political economy and political security relations, both at the domestic and international levels.

So far, the Indonesian government's attention to the energy sector is still oriented towards energy management at the domestic level. At the same time, its attention to foreign policy is still not optimal. Indonesia should have played a significant role at the international level because Indonesia has abundant natural resources, especially oil, natural gas and coal.

\footnotetext{
52 Corvinus University of Budapest, Doctoral School of International Relations and Political Science, PhD
} Student, donie.kadewandana@stud.uni-corvinus.hu 
Indonesia has enormous potential in energy, oil reserves of 9 billion barrels with a production capacity of 500 million barrels per year, gas reserves of 182 trillion cubic feet with a production capacity of three trillion cubic feet per year, and coal reserves of 19.3 billion tonnes with a capacity production of 130 million tonnes per year (PRASETYONO 2008).

In this context, the Indonesian government has not seen energy as a strategic commodity, which is an important issue in foreign policy that can support Indonesian diplomacy's effectiveness and optimization, both at the regional and international levels. This condition is evident from the weak institutionalization process of energy security policies in government institutions at the forefront of Indonesian diplomacy. The government has also not encouraged the progress of national and private energy companies and other stakeholders to become players in regional and international energy markets (ALAMI 2015). As part of the effort to look at the energy security side, this study places energy security as an important issue. This needs to be of concern for Indonesia's foreign policy and diplomacy. This chapter will analyze Indonesia's foreign policy in energy security issues.

\section{Energy Situation in Indonesia}

\subsection{Indonesian Energy Sources Production Conditions}

Indonesia is the fourth most populous country in the world. In 2020, the population is 270.20 million people (BPS 2020), with 80 percent concentrated in Java, Bali and Madura (IAE 2018). Indonesia, in reality, is abundant in natural resources, as evidenced by its vast oil, natural gas, and coal deposits and lifting. However, given the country's vast population, Indonesia's energy resources are not as great as they appear, as oil, natural gas, and coal reserves are depleting and will likely not last for more than 40 years, unless new proven energy resources are discovered (IBRAHIM 2006).

Indonesia is a crude oil exporter as well as a crude oil importer. It is the first in East Asia among natural gas exporting countries, third globally among coal exporting countries, and first in Southeast Asia among oil importing countries. Despite this, the number of confirmed oil reserves and lifting is decreasing (KURTUBI 2011).

Like other emerging markets, Indonesia's energy consumption has also experienced a rapid increase. Data shows that Indonesia's energy consumption percentage increased by an average of $2.6 \%$ per year from 99 Mtoe in 1990 to 240 Mtoe in 2017. Indonesia's primary energy consumption has steadily increased, from 0.71 tons of oil equivalent (toe)/capita in 2010 to 0.76 toe/capita in 2015 or growing by $1.5 \%$ per year. This trend is projected to continue to 
increase and requires the government to prepare related policies to ensure energy supply meets domestic needs (WINANTI et al. 2020).

Despite being a country that produces various forms of energy sources, Indonesia relies in particular for most of its energy fulfilment on fossil energy sources, such as oil, natural gas, and coal. According to data from the Ministry of Energy and Mineral Resources, 91.45 percent of Indonesia's energy needs in 2018 were supplied from fossil energy sources. This degree of dependence on fossil energy sources is expected to continue to increase. However, in recent years, the Indonesian government has begun to push for a shift towards meeting energy needs from renewable energy sources (KEMENTERIAN ENERGI DAN SUMBER DAYA MINERAL 2018).

\subsection{Energy situation: crude oil, natural gas, coal and new and renewable energy}

Indonesia's petroleum resources can be said to be very limited and have been widely used. According to data from the SKK MIGAS annual report (2016), for example, it shows that $92.1 \%$ of total reserves have been utilized. In particular, Indonesia's petroleum reserves in 2016 were 7,251.11 million stock tank barrels (MSTB), or decreased by $0.74 \%$ compared to the previous year. The current oil production is 338 million barrels per year. Considering the existing, proven oil reserves, it is estimated that proven oil reserves will be exhausted within the next nine years.

In the past, Indonesia was known as one of the largest producers of fossil fuel energy in the world, especially oil. However, this condition has changed along with the declining capacity of oil production and the increasing need for petroleum consumption in the form of fuel oil (Bahan Bakar Minyak/BBM). Since 2004, Indonesia has even been known as a net oil importer; in aggregate, the government must import petroleum to cover domestic energy needs (especially in fuel) (PWC INDONESIA 2018). EIA (2014) noted that Indonesia imports more than 441,000 barrels/day of oil. Most of these imports come from Saudi Arabia, Nigeria, and Azerbaijan. In a smaller percentage, several other countries are also sources of Indonesia's petroleum imports, namely Malaysia, the United Arab Emirates, Brunei Darussalam, and Angola. This need to import oil is closely related to the lack of oil refinery capacity in Indonesia. As a result, most of the imports are in the form of gasoline for vehicles, gasoil for power plants, liquid petroleum gas (LPG) for households, alternative fuels for aircraft (AFTUR), and diesel for vehicles and engines.

Interestingly, Indonesia continues to export petroleum even though it has become a net importer of total oil. This is due to the need to maintain market access and state revenue from 
oil production. In 2014, EIA reported that Indonesia's oil exports reached 381,000 barrels/day, and most of these exports were destined for countries in the region, such as Japan, Australia, Thailand, and China. However, oil exports are projected to continue to decline until reserves are exhausted by 2035. On the other hand, petroleum imports are projected to continue to increase to meet Indonesia's energy needs. BPPT data (2018) shows that oil fuel imports reached 22.9 kiloliters (KL) in 2016 and will increase by $6.3 \%$ growth per year to 182.3 million KL in 2050 (EIA 2014).

Like oil, natural gas reserves also decreased compared to 2017 by $5.04 \%$ (BPPT 2018). Nevertheless, Indonesia's natural gas reserves can be categorized as still quite significant. In 2015, EIA noted that Indonesia had natural gas reserves of 103.4 trillion cubic feet (tcf), and with this amount, Indonesia ranks13th largest in terms of natural gas reserves in the world and the second largest in the Asia-Pacific region.

Based on SKK MIGAS (2016) records only $34.5 \%$ of total natural gas reserves have been produced, implying that the opportunity for natural gas production is bigger than for oil. Nevertheless, there is a trend for a rising consumption of natural gas in Indonesia. EIA notes that domestic demand for natural gas has doubled since 2005. This makes it likely that gas exports will decrease in the future.

Indonesia's total coal resources up to 2015 were estimated at 127 billion tons, of which an estimated 32.3 billion tons were proven coal reserves (DITJEN MINERBA ESDM 2015). The majority of these coal reserves are characterized as low to medium rank (i.e. calorific value) and are mostly sourced on the islands of Sumatra (50 per cent) and Kalimantan (49.5 per cent), while the rest are scattered on other islands.

National coal production is projected to continue to increase. Although initially intended as an export commodity, national coal production has gradually led to meeting domestic needs, especially to meeting the needs of steam power plants (PLTU) and several industries, such as cement, textiles, steel, etc. It was recorded that in 2016, the share of Indonesian coal production exported was $79 \%$ and this is projected to continue to decline to $9 \%$ by 2050 . At the same time, imports of certain types of coal needed by industry are projected to increase from 4 million tonnes in 2016 to 11 million tonnes by 2050 (DITJEN MINERBA ESDM 2015).

Indonesia's potential for new and renewable energy (NRE) is quite large and consists of various sources. However, the potential of these various NRE sources has not been optimally harnessed due to various constraints such as geographical location and very high investment costs. Currently, the use of renewable energy is dominated by hydropower, especially in hydroelectric power plants (PLTA). In addition, other sources of NRE that are produced in 
limited quantities are biomass, geothermal, and biodiesel. On the other hand, the development and utilization of other renewable energy sources such as solar energy, wind, uranium, ocean waves, and tides are still very limited in Indonesia (DITJEN EBTKE 2016).

\subsection{Energy Consumption Projection Map}

Along with Indonesia's economic and population growth, demand for national energy is also projected to increase. The projection of domestic energy growth from 2016-2050 shows that final energy demand will increase by $5.3 \%$ per year. This will manifest itself in an increase in energy demand from 795 million barrels of oil equivalent (BOE) in 2016 to 4,569 million BOE in 2050. By 2050, the largest form of final energy consumption by energy source will be fuel, at $40.1 \%$, followed by electricity at $21.3 \%$, gas at $17.7 \%$, coal at $11.0 \%$, and the remaining LPG, biofuels (BBN), and biomass at each below 4\% (BPPT 2018).

When viewed in terms of energy utilization by sector, data from the Handbook of Energy and Economic Statistics of Indonesia (2018) indicated that the industrial sector ranked as the highest energy-absorbing sector in 2008 , with a consumption of 320,302,447 BOE. However, the pattern of energy consumption in this sector fluctuated with a relatively small upward trend. In 2018, the industrial sector only absorbed 334,446,969 BOE. This stands in contrast with the transportation sector, which in 2008 contributed to the energy consumption of $185,668,882$ BOE, experiencing a significant increase in 2018 to reach 391,397,487 BOE. This made it the largest contributor to Indonesia's energy consumption sector, beating the industrial sector. In addition, the household sector always ranks third, and the commercial sector ranks fourth in terms of Indonesia's energy consumption (KEMENTERIAN ENERGI DAN SUMBER DAYA MINERAL 2018).

\section{Energy Security in a Global Constellation}

In the global context, energy security has become an issue and agenda for the foreign policy of world countries. Energy is not only seen as an important component for national economic growth and international commodity markets but also has strategic value for national and international security policies. Securitization of energy issues raises the concept of energy security. Burgess, an American physician and politician, said that currently, energy has become a central dimension in formulating security policies. Whenever there is a fluctuation in world oil prices and related regional instability, such as conflicts or disruptions to distribution channels, it is always a concern of developed industrial consuming countries. These countries 
carry out strategic calculations to secure oil supplies even with the use of military force, if necessary. Therefore, energy and its availability and access are vital objects to be secured by using various resources owned by countries in the world (SYNDER 2008).

Conceptually, DEESE defines energy security as a condition in which a country feels a high probability that it will have an adequate supply of energy, both traditional and nontraditional, at affordable prices. DEESE emphasized that the safe condition in this energy issue is a guarantee of energy sources, distribution channels, and price stability (DEESE 1980).

International Energy Agency data shows a significant increase in world energy consumption since the beginning of 1990 and is projected to increase until 2040. Data shows an increase in world energy consumption by around $62 \%$, from 8,761 million tonnes of oil equivalent (Mtoe) in 1990 to 14,126 Mtoe in 2018. The energy needs are mostly met from nonrenewable energy sources such as oil, natural gas, and coal (EIA 2010).

When mapped from these global data, the level of energy consumption of non-OECD countries contributed more and experienced a relatively high increase compared to the OECD countries' level of energy consumption. In 2016 the energy consumption of non-OECD countries stood at 230.8 quads and is projected to increase significantly to reach 400.1 quads in 2030 (see Figure 10) (STATISTA 2013). ${ }^{53}$

Among non-OECD countries, China and India experienced the highest levels of consumption. In 1990, their consumption level reached $10 \%$ of total world consumption and increased by 20\% in 2007 (EIA 2010). China and India are the largest consuming countries and the first to be the most ambitious in developing energy diversification types and sources.

\section{Indonesia's Foreign Policy in Energy Security}

Like other countries in the world, Indonesia also faces the same problem related to the increasing demand for energy amidst limited energy sources available. Until now, oil, natural gas and coal are still the primary sources of fossil energy in almost all countries. In the long term, the increasing demand will be difficult to fulfil from limited fossil energy sources, due to to climate-related problems. Therefore, efforts to seek renewable energy sources are growing and encouraging the emergence of energy security policies in various countries.

\footnotetext{
${ }^{53}$ The OECD's members are: Austria, Australia, Belgium, Canada, Chile, Colombia, Czech Republic, Denmark, Estonia, Finland, France, Germany, Greece, Hungary, Iceland, Ireland, Israel, Italy, Japan, Korea, Latvia, Lithuania, Luxembourg, Mexico, the Netherlands, New Zealand, Norway, Poland, Portugal, Slovak Republic, Slovenia, Spain, Sweden, Switzerland, Turkey, the United Kingdom and the United States.
} 


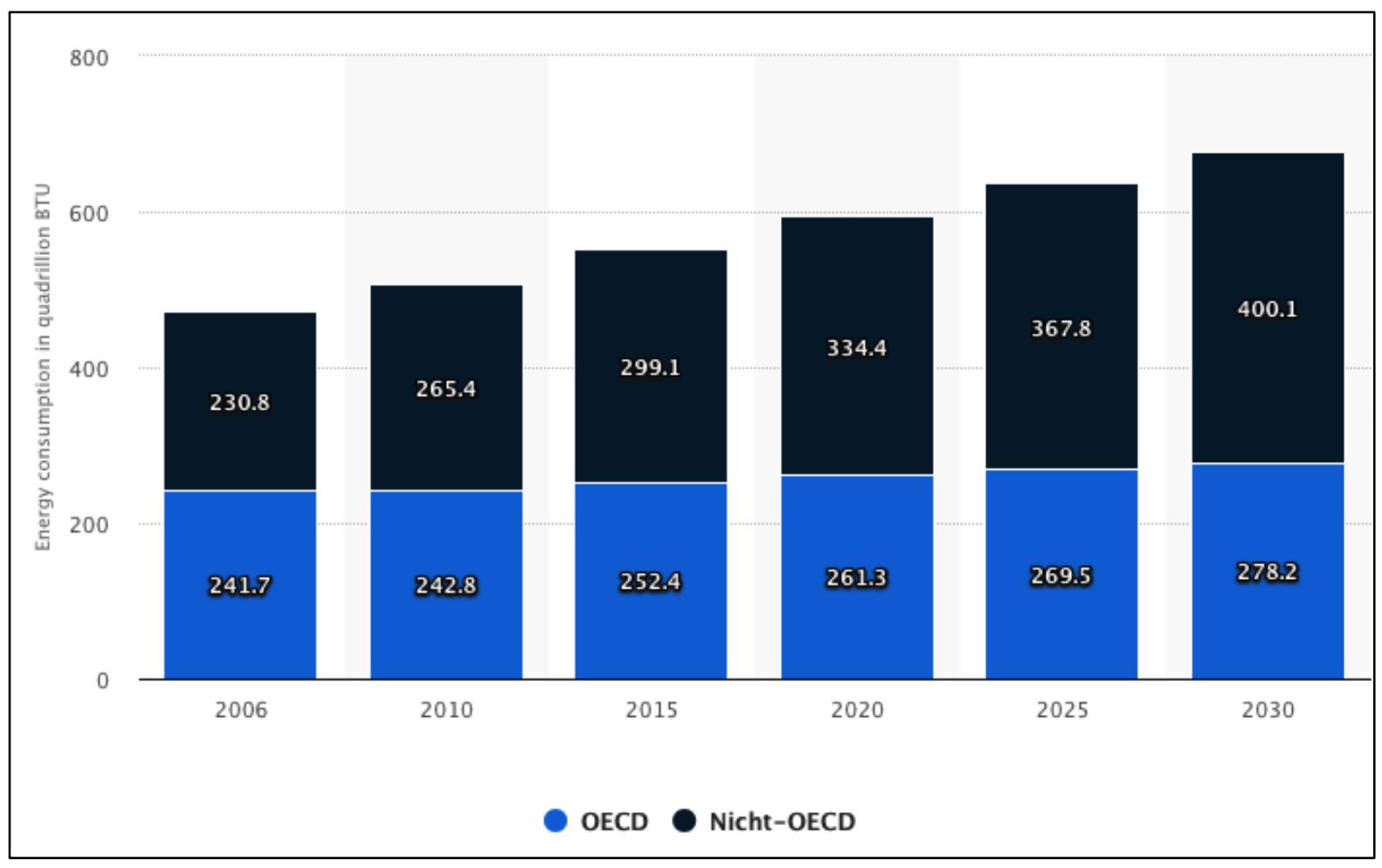

Figure 10: Comparison of predicted increase in energy consumption between OECD and non-OECD countries in 2006-2030 [unit: in quadrillion British Thermal Units (BTU)] (Note: "Nicht-OECD" in chart needs to be translated: "Non-OECD”)

Source: Statista 2013 https://www.statista.com/statistics/263991/energy-consumption-in-oecd-and-non-oecdcountries-until -2030/

According to the US Energy Information Administration, in 2018 Indonesia was the 9th largest energy-consuming country in the world and the largest among ASEAN member countries (EIA 2018). Data shows that the percentage of Indonesia's energy consumption increased by an average of $2.6 \%$ per year from 99 Mtoe (million tonnes of oil equivalent) in 1990 to 240 Mtoe in 2017. Indonesia's primary energy consumption per capita has steadily increased from 0.71 tonnes of oil equivalent (toe)/ capita in 2010 to 0.76 toe/capita in 2015 , or by $1.5 \%$ per year. This trend is projected to increase and requires the government to introduce related policies to ensure energy supply meets domestic needs (WINANTI et al. 2020).

Despite being a country that produces various forms of energy sources, Indonesia still depends on fossil energy sources for most of its energy fulfilment, such as petroleum, natural gas and coal. Based on data from the Ministry of Energy and Mineral Resources of Indonesia, 91.45 per cent of Indonesia's energy needs in 2018 were supplied from fossil energy sources (see Table 5). The degree of dependence is expected to continue to increase. However, in recent years, especially during the President Joko Widodo era, the government has begun to encourage a shift towards meeting energy needs from renewable energy sources. 
To achieve energy security and energy independence, the Indonesian government needs support from various stakeholders. Institutionally, there are several government institutions and agencies that have an interest in energy issues in Indonesia. They include the Ministry of Energy and Mineral Resources, the Ministry of Forestry, the Ministry of Development and Environment, the Ministry of Trade, the Ministry of Industry, the Ministry of Foreign Affairs, and the National Energy Council. Various institutions' involvement implies that efforts to meet national energy needs are carried out at both the domestic and international levels.

In addition, financial support from foreign investors is very important due to the government's inability to finance all exploration and exploitation of new energy resources. During the intense global energy competition lately, inviting foreign investors to Indonesia is certainly not an easy task for the government. In addition to a conducive investment climate, diplomacy with foreign investors also plays a very important role in a country.

Especially during the second term of President Joko Widodo elected for 2019-2024, the government began planning a new and renewable energy policy, which became one of the national energy policy pillars. President Jokowi emphasized that renewable energy is the future of national energy fulfilment and pledged to reduce Indonesia's dependence on fossil energy, particularly petroleum (KUSUMAWARDHANI 2019).

The priority of developing new and renewable energy as a pillar of national energy policy cannot be separated from the role of diplomacy. External and internal factors drive this. From the external side, this policy is part of Indonesia's commitment to the global agenda. In the Paris Agreement, the Indonesian Government is committed to making new and renewable energy an important component in the $23 \%$ national energy mix by 2025 (SETIAWAN 2019). This commitment is part of an action plan to respond to the climate change narrative. However, this energy mix target does not appear to be easy to achieve, given the low target achievement to date. A policy vision is not necessarily followed by a concrete and measurable policy action plan at the technical level of government programs. Apart from external factors, new and renewable energy development policies are also driven by domestic interests, including the need to reduce the Current Account Deficit (CAD), energy diversification to ensure distribution supply, and energy development based on local resources (WIJIATMOKO 2017). 


\begin{tabular}{|c|c|c|c|c|c|c|c|c|c|c|c|c|c|}
\hline YEAR & COAL & $\begin{array}{c}\text { CRUDE } \\
\text { OIL \& } \\
\text { PRODUCT }\end{array}$ & $\begin{array}{l}\text { NATURAL } \\
\text { GAS \& } \\
\text { PRODUCT }\end{array}$ & $\begin{array}{l}\text { HYDRO } \\
\text { POWER }\end{array}$ & GEOTHERMAL & $\begin{array}{c}\text { SOLAR } \\
\& \\
\text { SOLAR } \\
\text { PV }\end{array}$ & WIND & $\begin{array}{c}\text { OTHER } \\
\text { RENEW- } \\
\text { ABLES }\end{array}$ & $\begin{array}{c}\text { SOLAR - } \\
\text { POWERED } \\
\text { STREET } \\
\text { LIGHTING } \\
\& \\
\text { ENERGY } \\
\text { SAVING } \\
\text { LAMP } \\
\end{array}$ & BIOMASS & BIOFUEL & BIOGAS & TOTAL \\
\hline 2008 & 224 & 476 & 236 & 29 & 13 & n.a & n.a & n.a & n.a & 114 & 0,06 & n.a & 1,092 \\
\hline 2009 & 236 & 478 & 251 & 28 & 15 & n.a & n.a & n.a & n.a & 109 & 0,77 & n.a & 1,117 \\
\hline 2010 & 282 & 464 & 270 & 41 & 15 & n.a & n.a & n.a & n.a & 107 & 1 & n.a & 1,180 \\
\hline 2011 & 334 & 563 & 261 & 28 & 15 & n.a & n.a & n.a & n.a & 105 & 2 & n.a & 1,308 \\
\hline 2012 & 345 & 589 & 259 & 29 & 15 & n.a & n.a & n.a & n.a & 99 & 4 & n.a & 1,340 \\
\hline 2013 & 302 & 587 & 270 & 38 & 15 & n.a & n.a & n.a & n.a & 95 & 6 & n.a & 1,313 \\
\hline 2014 & 320 & 584 & 271 & 38 & 16 & n.a & n.a & n.a & n.a & 92 & 11 & n.a & 1,332 \\
\hline 2015 & 364 & 607 & 275 & 35 & 16 & n.a & n.a & n.a & n.a & 84 & 6 & n.a & 1,387 \\
\hline 2016 & 380 & 534 & 277 & 45 & 17 & n.a & n.a & n.a & n.a & 80 & 19 & n.a & 1,352 \\
\hline 2017 & 407 & 567 & 275 & 47 & 20 & n.a & n.a & n.a & n.a & 75 & 16 & n.a & 1,407 \\
\hline 2018 & 483 & 569 & 288 & 40 & 26 & 0,35 & 0,46 & 29 & 0,008 & 67 & 28 & 0,16 & 1,530 \\
\hline
\end{tabular}

Source: Author's edition based on the data of KEMENTERIAN ENERGI DAN SUMBER DAYA MINERAL, HANDBOOK OF ENERGY \& ECONOMIC STATISTICS OF INDONESIA 2018. 
In the context of international relations, diplomacy serves to improve relations and discuss each country's national interests. Given the situation above, the role of energy diplomacy is as important as political and security diplomacy because it also involves vital national interests. In this context, Indonesia's energy diplomacy is very much oriented towards meeting energy needs to support sustainable development implementation. Although the Ministry of Foreign Affairs is one of the leading institutions in implementing Indonesia's energy diplomacy, institutionally this energy diplomacy activity is spread across various ministries, or what is known as sectoral energy diplomacy. In practice, other actors, especially technical ministries such as the Ministry of Energy and Mineral Resources, the Ministry of Trade and the Ministry of Forestry, are also involved in energy diplomacy activities with foreign parties, namely cooperation carried out with other countries in the energy sector, for example between the Indonesian Ministry of Forestry and the Ministry of Energy of Brunei Darussalam (ANGGORO 2011).

In accordance with the foreign policy principle of being free and active in forging partnerships and cooperation in energy development, the Indonesian government is currently actively involved in various international energy cooperation frameworks. This cooperation is promoted through various international forums (bilateral, regional and multilateral) and international institutions (UN and non-UN). According to the Ministry of Energy and Mineral Resources of the Republic of Indonesia as quoted by Alami, Indonesia is currently involved in nearly one hundred types of international energy forums. Of the hundreds of cooperation forums, ironically, there are only a few cooperation forums that have entered the stage of activities that are operational (ALAMI 2015).

Several international energy collaborations which are at the operational level are moving forward; among others that can be noted are: the Indonesia-Japan energy cooperation for technology transfer and institutional improvement; Indonesia-Netherlands energy cooperation for new and renewable energy, especially power generation from micro-hydro; work energy cooperation between ASEAN countries, which includes the establishment of the ASEAN Power Grid; the Trans-ASEAN Gas Pipeline; and the ASEAN Forum on Coal. The ASEAN Energy Cooperation focuses its activities on the oil and gas sector as well as pursuing alternative energy through the development of new and renewable energy. The Indonesia-China energy cooperation takes the form of investment, and the Indonesia-Norway energy cooperation is related to reducing carbon emissions (NICOLAS 2009). In addition, there are several international energy collaborations that have no continuation at all, and many of these 
collaborations are still limited to norm-setting, such as memoranda of understanding (MoU), letters of intent (Lol), and others.

The above reality needs to be understood especially in relation to international relations, which are increasingly complex at this time. Diplomacy, as we know it conventionally, has been transformed in accordance with the times in which we live. This definition implicitly shows that diplomacy is the exclusive field of diplomacy of the Ministry of Foreign Affairs. However, significant changes in the conditions of international relations in modern times, especially due to the rapid development of globalization, liberalization and technology, have broken through the boundaries of professional diplomacy that were previously synonymous with the ministry of foreign affairs through their diplomats. Diplomatic activities no longer belong only to diplomats but also involve other government and non-government actors such as technical ministries, non-governmental organizations, business and private sectors, nongovernmental organizations, parliament members, and academics and non-governmental organizations (ALAMI 2017).

Indonesia's energy diplomacy, which is spread across various ministries with their respective competencies, should not cause problems if cross-sectoral coordination is well managed. Only, in reality, this function seems to be still not running in an integrated manner. So far, the Indonesian Ministry of Foreign Affairs, which has a central role in diplomacy, namely as a coordinator and consultant for other international actors in establishing foreign relations, in fact, has not optimally carried out its function. In addition, it is time for the Indonesian Ministry of Foreign Affairs to set up a special directorate that deals with energy issues.

Cross-sectoral coordination plays a central role in Indonesia's energy diplomacy, which simultaneously involves many players. Diplomacy will be useful if there is effective coordination among the players. It is hoped that the communication generated through this coordination will bring synergy between energy diplomacy actors in determining the issues they will present at international forums.

In the current context, diplomacy is not the exclusive domain of the state. In multi-track diplomacy, the government is not the only actor. Diplomacy involves professional participation from businesses, citizens, educators, peace activists, religious institutions, funding platforms, and media opinion and public perception. By combining all relevant actors' efforts, countries can use total diplomacy (DIAMOND - MCDONALD 1996).

Indonesia needs total diplomacy to build partnerships with international diplomacy actors where the scope of diplomacy is expanding. By involving increasingly diverse actors, both state 
and non-state, Indonesia's bargaining power in the negotiation process will be strengthened. In addition, Indonesia needs total diplomacy because in every negotiation, the ability to follow up on agreements is often not optimal. It is not enough for Indonesian diplomacy to stop after creating understanding; the most important thing is implementing that understanding. Through total diplomacy, the gap between desire and implementation will be resolved more quickly, given the various actors involved.

Therefore, an understanding of total diplomacy can facilitate the organization of strategies in dealing with stakeholder institutions at the international level. Total diplomacy is essentially a form of negotiation carried out, both formally and informally, by involving many parties, not only between governments but also by the private sector, through informal networks. Total diplomacy should address the goals of securing energy supplies, accessing markets and investing outside the country, as well as ensuring the sustainable transformation of the main energy source from fossil to renewable energy.

Total diplomacy in the energy sector can be supported through three activities: knowledge production, stakeholder engagement and new public diplomacy. Stakeholders such as the civil society, media and public opinion need to get a bigger picture of Indonesia's energy security goals. The new public diplomacy must be able to use all available methods to reach the general public. A new public diplomacy should also avoid one-way communication by providing opportunities for an exchange of views. This effort takes advantage of active discussion through education, youth peace activism, religious groups as well as massive distribution on major media and social media.

It is hoped that the state will no longer depend solely on the skills of career diplomats in global diplomacy forums. Indonesian citizens, both at home and abroad, can also contribute to the image of the Indonesian nation in the international arena. Total diplomacy provides many creative and innovative steps developed by all components of the nation. However, the implementation of total diplomacy is based on simple assumptions; that is, the government cannot alone overcome various challenges in increasingly complex international issues without the involvement of many stakeholders. By increasing diplomatic activities that include many stakeholders, energy diplomacy efforts will run more effectively and have a broader impact on the international community. 


\section{Conclusion}

Energy security is currently still a concern of the international community and is part of countries' foreign policy in the world. The goal of energy security is to secure a country's energy supply and needs. To fulfil this, strategic efforts are needed in dealing with energy problems, both at the national and international levels.

Foreign policy is an inseparable part of efforts to achieve the goal of energy security policy. Based on the principle of a free and active foreign policy, the Indonesian government has built international energy partnerships and cooperation through various international forums and institutions. Through these various collaborations, Indonesia has a unique opportunity to take advantage of technology transfer, capacity building, and investment. However, it seems that Indonesia has not yet optimized all the opportunities that exist. In addition, there is still no institutionalization of international energy security policies at the level of the Indonesian Ministry of Foreign Affairs.

The strategic effort that Indonesia needs to make in energy security in the international sphere is the need to build total diplomacy. It is hoped that the state will no longer depend only on diplomats' capabilities in global diplomacy forums. Indonesian citizens and other stakeholders, both at home and abroad, can also contribute to the Indonesian nation's image in the international arena. By increasing diplomatic activities that include many stakeholders, it is hoped that Indonesia's energy diplomacy efforts will run more effectively and have a broader and more significant impact on the international arena.

\section{References}

ALAMI, A. N. 2015: Politik Luar Negeri Indonesia dan Isu Keamanan Non-tradisional. Journal Penelitian Politik. Jakarta: LIPI Pers. Available at: https://ejournal.politik.lipi.go.id/index.php/jpp/article/view/543/357 Accessed on 21 January 2021.

ALAMI, A. N. - WURYANDARI, G. - YUSTININGRUM, E. - SRIYANTO, N. 2017: Foreign Policy and Energy Security Issues in Indonesia. https://doi.org/10.1007/978-981$10-4421-2$.

ANGGORO, K. 2011: Indonesian Foreign Policy and Energy Security. June 16. Paper presented at the Focus Group Discussion on Indonesian Foreign Policy and Energy Security in Jakarta. Jakarta: P2P-LIPI. Available at: 
https://www.springerprofessional.de/en/understanding-indonesia-s-foreign-policy-onenergy-security-issu/12314928 Accessed on 21 January 2021.

BPPT: Badan Pengkajian dan Penerapan Teknologi 2018: Outlook Energi Indonesia 2018: Energi Berkelanjutan untuk Transportasi Darat. Jakarta: Badan Pengkajian dan Penerapan Teknologi. Available at: https://www.bppt.go.id/kebijakan-teknologi/3298-outlookenergi-indonesia-energi-berkelanjutan-untuk-transportasi-darat Accessed on 21 January 2021.

BPS: BADAN PUSAT STATISTIK. 2020: Hasil Sensus Penduduk 2020. Jakarta: Berita Resmi Statistik No 07/01/Th. XXIV. Available at: https://www.bps.go.id/pressrelease/2021/01/21/1854/hasil-sensus-penduduk-2020.html Accessed on 21 January 2021.

DEESE, D. A. 1980: Energy: Economics, Politics and Security. International Security 4 (3): pp. 140-153. https://doi.org/10.2307/2626698.

DIAMOND, L. - MCDONALD, J. 1996: Multi-track Diplomacy: A Systems Approach to Peace. West Hartford CT: Kumarian Press.

DITJEN MINERBA ESDM. 2015: Indonesia Mineral and Coal Information 2015. Jakarta: Kementerian Energi dan Sumber Daya Mineral. Available at: https://www.esdm.go.id/assets/media/content/content-handbook-of-energy-economicstatistics-of-indonesia-2015-uwe2cqn.pdf Accessed on 21 January 2021.

DITJEN EBTKE. 2016: Statistik EBTKE 2016. Jakarta: Kementerian Energi dan Sumber Daya Mineral. Available at: https://ebtke.esdm.go.id/post/2017/03/07/1583/statistik.ebtke.2016 Accessed on 21 January 2021.

EIA. 2018: U.S. Energy Information Administration. Washington: EIA.

EIA. 2014: U.S. Energy Information Administration. Washington: EIA.

EIA. 2010: U.S. Energy Information Administration. Washington: EIA.

GREEN, F 2018: Anti-Fossil Fuel Norms. Climate Change 150, pp. 103-116. https://doi.org/10.1007/s10584- 017-2134-6.

HEGARTY, K. 2018: The EU's war on palm oil will continue. The Jakarta Post. July 6. Available at: https://www.thejakartapost.com/academia/2018/07/06/the-eus-war-on-palmoil-will- continue.html Accessed on 21 January 2021.

IBRAHIM, H. D. 2006: Peran dan Prospek Pemanfaatan PLTN dalam Sistem Ketenagalistrikan Nasional. In: BPPK Kementerian Luar Negeri RI (eds). A Seminar Proceeding on Diplomasi Energi dalam Pemantapan Pembangunan PLTN di Indonesia. Jakarta. 
JAKARTA POST. 2018: Indonesia wins biodiesel anti-dumping case in EU appeal court. The Jakarta Post. Available at: https://www.thejakartapost.com/news/2018/03/21/indonesiawins-biodiesel- antidumping-case-in-eu-appeal-court.html Accessed on 21 January 2021.

KEMENTERIAN ENERGI DAN SUMBER DAYA MINERAL. 2018: Handbook of Energy \& Economic Statistics of Indonesia. Jakarta: Kementerian Energi dan Sumber Daya Mineral.

KURTUBI. 2011: Indonesian Foreign Policy and Energy Security. June 16. Paper presented at the Seminar on Research Findings. Jakarta: P2P LIPI. Available at: https://www.scribd.com/document/426930569/Athiqah-Nur-Alami-Ganewati-

Wuryandari-R-R-Emilia-Yustiningrum-Nanto-Sriyanto-auth-Foreign-Policy-and-EnergySecurity-Issues-in-Indonesia-Spri Accessed on 21 January 2021.

KUSUMAWARDHANI, A. 2019: Presiden Jokowi: Indonesia Mulai Arahkan Kebijakan Energi ke EBT. November 20. Bisnis.com. Available at: https://ekonomi.bisnis.com/read/20191120/44/1172624/presiden-jokowi-indonesiamulai-arahkan-kebijakan-energi-ke-ebt Accessed on 21 January 2021.

NICOLAS, F. 2009: ASEAN Energy Cooperation: An increasingly Daunting Challenge. Paris: Notede l'Ifri.

PRASETYONO, E. 2008: Energy Security: an Indonesia Perspective. In: MARQUINA, A. (ed): Energy Security Vision on Asia and Europe. New York: Palgrave Macmillan.

PWC INDONESIA. 2018: Oil and Gas in Indonesia: Investment and Taxation Guide. Jakarta: PwC Indonesia. Available at: https://www.pwc.com/id/en/energy-utilitiesmining/assets/oil-and-gas/oil-and-gas-guide-2018.pdf Accessed on 21 January 2021.

RAINFOREST ACTION NETWORK (RAN). 2017: The Human Cost of Conflict Palm Oil Revisited. Available at: https://www.ran.org/wpcontent/uploads/2018/06/Human_Cost_Revisited_vWEB.pdf Accessed on 21 January 2021.

RESOSUDARMO, B. P. - ALISJAHBANA, A. - NURDIANTO, D.A. 2012: Energy Security in Indonesia. In: ANCESCHI, L. - SYMONS, J. (eds.). Energy security in the era of climate change: The Asia Pacific experience. Palgrave Macmillan, London. https://doi.org/10.1057/9780230355361_10.

SETIAWAN, V. N. 2019: Indonesia Sulit Capai Bauran Energi 23\% Meski Potensi EBT Cukup Besar. 25. Keptember Aatada.co.id. Available at: https://katadata.co.id/berita/2019/09/25/indonesia-sulit-capai-bauranenergi-23-meskipotensi-ebt-cukup-besar Accessed on 21 January 2021. 
SKK MIGAS 2016: Satuan Kerja Khusus Pelaksana Kegiatan Usaha Hulu Minyak dan Gas Bumi. Laporan tahunan. Available at: https://www.skkmigas.go.id/publikasi/annualreport?_cf_chl_jschl_tk_=pmd_8b00e1ad1e94764792278936d302a566d5da21b41626718365-0-gqNtZGzNAeKjcnBszQhi Accessed on 21 January 2021.

SOERIAATMADJA, W. 2018: European Ban on Palm Oil in Biofuels Upsets. - Jakarta - KL. The Strait Times, January 24. Available at: https://www.straitstimes.com/asia/seasia/european-ban-on-palm-oil-in-biofuels-upsets-jakarta-kl Accessed on 21 January 2021.

STATISTA. 2013: Expected Energy Consumption by World Regions from 2006 to 2030. Available at: https://www.statista.com/statistics/263991/energy-consumption-in-oecdand-non-oecd-countries-until-2030/ Accessed on 21 January 2021.

SYNDER, C. A. 2008: Contemporary Security and Strategy. New York: Palgrave Macmillan.

WIJIATMOKO, B. 2017: November 7. EBT penting untuk masa depan ketahanan energi nasional. Kementerian ESDM. Available at: http://ebtke.esdm.go.id/post/2017/11/07/1809ebt.penting.untuk.masa.depan.ketahanan.en ergi.nasional Accessed on 21 January 2021.

WINANTI, P.S. - MAS'UDI, W. - RUM, M. - NANDYATAMA, R. 2020: Diplomasi Energi Indonesia. Yogyakarta: Fakultas Ilmu Sosial dan Politik Universitas Gadjah Mada. DOI: 10.6084/m9.figshare.12030381. 


\title{
Labeling of statuses and its effects on human rights of the Rohingya people in Bangladesh: Rhetoric and Reality
}

Sodip ROY ${ }^{54}$

\begin{abstract}
Bangladesh is a sanctuary of 1.2 million Rohingya people who have fled from the state-run persecution against them in Myanmar. They have been stripped of their citizenship rights of their birth and ancestral land, Burma, present-day Myanmar. Currently, they are the largest stateless minority in the world. The first exodus occurred in 1978 and the last in 2017. The Rohingya people have been identified by many different names: Registered refugee, Unregistered refugee, Undocumented Myanmar Nationals, and Forcibly Displaced Myanmar Nationals so far here in Bangladesh. By taking up the issue, this study examines why the labeling of the Rohingya people and how it affects their human rights in the refugee camps in Cox's Bazar of Bangladesh. To that end, this investigation explores and collects data from secondary sources in a qualitative setting. After an exploration of the relevant literature and secondary data, it comprehends that the naming of the Rohingya people in different statuses has considerable effects on their human rights. Those labeling and stratifications are involved with discrimination as well as deprivations of the Rohingya people. Finding the labeling a political issue, this study recommends considering their human rights as human being irrespective of labeling them in pejorative categories.
\end{abstract}

Keywords: labeling, host, humanitarian provision, human rights, discriminations.

\section{Introduction}

The refugee crisis and the number of refugees have reached an unprecedented high in recent times globally. The term 'refugee' has a strong and explicit legal basis. The label refugee is the most privileged status of forcibly displaced people (ZETTER 2007), and only as refugees, those people can enjoy many human rights except citizenship rights for the time being (MARFLEET 2006). Criteria are also quite clear to determine who is a refugee and who is not. But the definition attracts much contested connotation with individual interest and purposes of the nation-states. Now there is much labeling of forcibly displaced people even though having explicit criteria of refugeehood. Empirical studies contend that labeling matters to the life and livelihood of incumbents. LEE and NERGHES (2018) claim that the labeling of displaced individuals may harm their safety and lives; negative framing may undermine their position in the host country, it may even create vulnerable identities (SERUGHETTI 2018) and wrong perception against them. Nevertheless, it is a widely used phenomenon to the twenty-first century forcibly displaced people around the globe.

Bangladesh is a host country of 1.2 million Rohingya people, including many newborns in Bangladesh. For hundreds of years they lived in Burma, present-day Myanmar, (IBRAHIM 2016; WADE 2017) but they were stripped of their citizenship rights during the junta

\footnotetext{
${ }^{54}$ Corvinus University of Budapest, Doctoral School of International Relations and Political Science, PhD student, Faculty member of Political Science, Open School, Bangladesh Open University, Bangladesh, sodip.roy@stud.uni-corvinus.hu
} 
government in 1982. Now they are the largest stateless minority people in the world (AHSAN ULLAH 2016). The first exodus occurred in 1978 and the last in 2017. Their camps are situated in the Teknaf and Ukhya area of the southeastern district Cox's Bazar (CXB) of Bangladesh. Locally, the zones are known as Nayapara camp and Kutupalong camp respectively in those two areas. The Rohingya people have been identified by many different names: Registered refugee, Unregistered refugee, Undocumented Myanmar Nationals (UMNs), and Forcibly Displaced Nationals (FDMNs) so far since 1978 here in Bangladesh (ZETTER - RUAUDEL 2016; SULTANA 2019). Approximately 30,000 of them have refugee status while the rest of the population are known as unregistered refugee or UMNs. Newcomers are registered as Forcibly Displaced Myanmar Nationals (FDMNs) in Bangladesh and live mainly on humanitarian provisions. They also have many informal labeling terms such as 'victims, problems, threat or burden for Bangladesh (GUHATHAKURTA 2017; RAHMAN 2010; PARNINI et al. 2013). Both the categories and the labeling have had negative effects on these ill-fated people. Normally the services and facilities vary according to this labeling. The issue of labeling of refugees now does not only affect distribution of services but it reveals the political agenda and other external 'Othering' factors (VIGIL - BAILLIE 2018; ZETTER 2007). By taking up the issue, this study has been conducted to identify the reasons of labeling of the Rohingya people in Bangladesh as well as to investigate the implications of the labeling of their human rights. The findings and analysis will offer a scope to understand the implications of labeling in a developing country perspective, however, further study can be conducted to examine the difference of its impact in the case of a developed country context.

This article is organized into six parts. The first section has highlighted an overview of the intensity of refugee crisis and background of the study. The section that follows, outlines the key concept 'labeling of refugee- like people' and human rights from relevant literature, sets the scene of the paper. The third part briefly demonstrates the study procedure. And the fourth section illustrates the formal labeling of the Rohingya people since 1978 to till date. The fifth section analyses reasons behind the labeling and its effect of human rights on these categorized people. And finally, it sums up that it is high time for policymakers, practitioners, and researchers to raise their voice against this pejorative category of refugee like people. This part also recommends some actions in redressing the Rohingya refugee crisis and other crises alike. 


\section{Conceptual framework}

In response to the magnitudes of the problem, the international refugee regime (IRR) led by UNHCR so far has devised three durable solutions: repatriation, local integration, and resettlement. Encountering a myriad of challenges in executing its mandate of three durable solutions, it can hardly bring the host country, home country or third country to a single table, or can manage funding to that end. UNHCR has a universal mandate about the management of the refugee crisis but there is no obligation for many state parties to rectify the 1951 Conventions as well as to approve durable solutions of refugee crisis till date (TÜRK - DOWD 2014).

The UN Refugee Convention of 1951 is oftentimes called the convention for the solution of the refugee crisis in Europe (CHIMNI 2004). Since the Cold war period, European countries were exhausted to accept and integrate refugees or economic migrants even after the rectification of the convention. In this situation the label 'asylum seekers' continued to apply to (irregular) migrants since the 1990s (ZETTER 2007). ZETTER (2007) further maintains that the term 'labeling' refers to an extremely complex set of values and judgments which is determined by the intervention and interests of state and non-state actors, and upon the actions and demands of the labeled subjects, who are requested to conform to and incorporate it. By Labeling it constraints the specific protection needs of forcibly displaced migrants in the hour of need and ignore their meaningful agencies of choices for well-being (SERUGHETTI 2018). However, VIGIL and BAILLIE (2018) argue quite differently in refugee integration in Canada that after a proper resettlement, refugees can create their own labeling and identities as 'we' instead of 'us' and 'them'. But whilst only a minimum percentage (1\% in 2018) of the total refugee can resettle in a proper way in the western countries (UNHCR 2018), this type of positive labeling can just be an example, not the change makers for hundreds of thousands of refugees. To put it another way, there is no guarantee of human rights for the rest of the refugees around the globe.

Human rights are a norm. These rights are an inalienable and fundamental irrespective of the color, creed, size of the ethnic group, religion, language or any other status but only because of being a human being (UNOHRHC 2021). Besides, there are ranges of legal frameworks and interpretations of human rights. Resultantly, it is also a legal issue. Different national, regional, and international entities have formulated and adopted those legal frameworks to safeguard human rights, even for those who are not in a normal setting such as refugee and so on. But the human rights of refugee-like people depend on refugee governance 
which is quite different in the global south compared to those in the global north. Any refugee can avail most of the human rights in Western countries upon receiving refugee status. They can be free from want as well free of fear in that regard. But it is crucial in the present day whether one will be granted that status or any other pejorative categories. Besides a refugee framework, human rights issues of refugees have been decisively challenged by the state interest and international system (AMIT 2019). On the other hand, refugees in the global south normally have no refugee status and no freedom from want or fear. They struggle to survive for extended exile in a de facto refugee situation in which different labeling can affect their minimum rights in the camps. Although human rights here refer to limited senses such as freedom of movement, right to work, food, shelter, water-sanitation, health.

\section{Methodology}

The study has adopted a qualitative methodology based on secondary resources. For this investigation, it explored documents and literature both for theoretical purpose as well as metadata. So, the literature includes but not exhausted to relevant study on labeling and human rights of refugees, and the reports by the Government of Bangladesh (GoB) and UNHCR, human rights report by NGO-INGO, popular media reports on the Rohingya people in Bangladesh. Moreover, some of the latest data have been collected from web searching. Several field visits and field observations in Teknaf and Ukhya of CXB for other research purposes in 2019 were also helpful to substantiate some claims from secondary data. Refined data has been presented accordingly to the objectives of the study.

\section{Labeling to Rohingya People in Bangladesh}

\section{1. 'Registered Refugee' labeling of Rohingya people}

The Rohingya crisis is rooted in British colonial legacy in Burma (SMITH 1999; IBRAHIM 2016; WADE 2017) and the Rohingya Muslims have a long history of labeling. In the post-Second World War period, the formation of nation and nation-state was expedited everywhere in the world including in Burma. Unlike in other parts of the British colony, Burma has also been suffering from dire consequences of the 'divide and rule' policy. Subsequent authoritarian rulers also exploited those ethnic divisions to consolidate their power. Moreover, the Burmanization process intentionally included the erasing of century-long evidence of Rohingya Muslims and rewriting and forming of contra-Rohingya discourse to exclude them from the territory (WADE 2017). Eventually, the exclusion resulted in the labeling of the Rohingya Muslims as 'Other' or foreigners in their ancestral land in Burma under the contested 
Citizenship Law of 1982. From British colony to an independent Bangladesh (the then East Pakistan), there were no strict borders between the two countries. Even after the independence, people of the Rakhine state of Burma and Bangladesh could move between them without immigration issues because of porous bordering between the regions of countries (BJORNBERG 2016). Resultantly, the Rohingya people could run away to Bangladesh in case of any kind of persecution against them by the authoritarian military government in Burma. The first exodus of the Rohingya people took place in 1978 which was resolved bilaterally without extending the crisis. But both the border and sovereignty continued to be stricter in the postCold War period with rising of nation-state. Similarly, the refugee issue has also turned into a crisis and a matter of scientific study. The frequency of persecution against the Rohingya people and the period of exile continued to increase since 1990. Consequently, hundreds of thousands of Rohingya people fled to Bangladesh in 1991, 2012, 2014, and 2017.

Some 200,000 Rohingya people returned to Myanmar in 1994-95 from the influx in the 1990s. There was an accusation of involuntary repatriation (GRUNDY-WARR - WONG 1997). Approximately 30,000 Rohingya people could escape the repatriation. And the humanitarian organization led by UNHCR urged the government to accept them as refugees. Since Bangladesh is not a state party of the UN Refugee Convention of 1951 and protocol in 1967, GoB did not accept the Rohingya as refugees. However, they eventually received special recognition as refugees by the UNHCR, and later, GoB also accepted that status of those Rohingya to end the refugee crisis in Bangladesh at that time (GHOSH 2018). They are also called the 'people of the UNHCR (SULTANA 2019). Two (government) camps were built up in Nayapara of Teknaf and Kutupalong of Ukhiya area of the district. Every one of them got an identity card although that was not much useful in protecting them from vulnerabilities.

\subsection{Undocumented Myanmar Nationals (UMNs)}

Besides the registered refugee status, there were more than 200,000 Rohingya people, living in the makeshifts and inside the local community (KIRAGU et al. 2011) before 2017. They were not registered in any government jurisdiction, though a government statistic revealed the total number as 300,000-500,000 (GoB 2014; IOM 2016). And this group of undocumented the Rohingya people was labeled as Undocumented Myanmar Nationals (UMNs). Ad hoc makeshifts camps near the Kutupalong became their sanctuary. UMNs did not receive any support from UNHCR and GoB. They are also considered as unregistered refugees. Thus, everything such as shelter, sanitation, health services were unplanned and unhygienic to live in. They had no identity card. UMNs had to manage their livelihood themselves except for some 
ad hoc humanitarian aid through NGOs. But the area was intentionally left so underdeveloped that there were not even any sufficient employment opportunities for the host community people. Since there is no legal and administrative framework to maintain refugee and asylum seekers in Bangladesh, the Rohingya people were treated under the Foreigners Act (FA) of 1946. According to this Act, UMNs can be subjected to imprisonment for up to five years and fines (IOM 2016).

\subsection{Forcibly displaced Myanmar Nationals (FDMNs)}

The largest influx of Rohingya people in 2017 brought forth new labeling for them in the refugee camps in Bangladesh. They live in the thirty-four settlement camps in Nayapara and Kutupalong. The sudden influx and growth of the camps blurred the earlier demarcation between registered and UMNs (Author's field visit in 2019). Currently, almost all the Rohingya people are named as Forcibly Displaced Myanmar Nationals (FDMNs) (DAILY STAR 2017). This time the Rohingya conundrum has attracted most of the international agencies for humanitarian assistance. Every one of them is under UNHCR led humanitarian provision. They receive very basic needs such as food, shelter, health care on a minimum scale on monthly basis. GoB is against their scope of self-reliance (BIGD 2018). Humanitarian organizations work as implementing agencies in the labeling of these statuses to the Rohingya people. In a present-day nation-state system, these organizations can hardly make any influence on the states' decisions. FDMNs have no identity card but are documented based on household. Kutupalong is the largest and most densely populated camps in the world with approximately 1 million Rohingya people (VINCE 2020).

\section{Why label the Rohingya people?}

Labeling is not objective rather it holds a deep meaning to the targeted groups. Bangladesh did not accede the UN Refugee Convention since it believes that it is not capable of fulfilling the legal bindings of the convention and protocol. Considering the lifesaving of the Rohingya people it attempted to manage them in a bureaucratic way, not under any national legal framework. Labeling has occurred both formally and informally. It is done initially for administrative purposes by the respective unit of government, a bureaucratic process (ZETTER 1991). Labeling is considered as essential for the proper governance of refugees and aliens. Some labels are created by the media and public discourses (LEE - NERGHES 2018) mostly the many informal labeling. 
Primarily, Refugee Relief and Repatriation Commissioner (RRRC) plays the key role in labeling and the management of the Rohingya people while the UNHCR assists in the entire process. UNHCR had no direct mandate for the protection of the Rohingya people. It dealt with the Rohingya issue under an MoU signed with Bangladesh in 1993. After the repatriation of the majority of the Rohingya of 1990s influx in 1994, GoB did not accept much support and proposal from UNHCR for the remaining Rohingya people (UNHCR 2011). And the current mandate was re-established since 2006 through different activity-based agreements mainly for protection and management. The implications varied in the case of the first exodus and the repeated influxes of the said people. The Rohingya people were just called the Rohingya during the exodus in 1978 but they got different labeling between in 1991 and 2017. This time it is not only administrative but also political since there is no policy of the government for such management. UNHCR, IOM however provided the technical and logistic support for the documentation, labels were decided by the GoB, that was a political decision. And UNHCR could conduct refugee status determination (RSD) only in Dhaka city of Bangladesh (UNHCR 2013). The Rohingya people encountered every well-founded fear to have refugee status but they are labeled as something else from time to time. Such politics strikes the very core of refugeehood. Informally, the Rohingya people are called criminals sex workers, a burden, 'local gypsies' (LOESCHER - MILNER 2008), and so on. It happened apparently because of that Bangladesh is not a state party of the UN Refugee Convention 1951. UNHCR including other NGOs cannot perform protection and assistance tasks without authorization of the GoB. But it is always not an issue of acceding this convention rather than involving history, ethnicity, socioeconomic conditions and so on. The movement of people between the porous border of Burma and Bangladesh changed reversely in the post independent period. Since then, more Rohingya people tend to enter Bangladesh than the Bangladeshi people in Burma. So, the GoB was extra cautious about the infiltration of the Rohingya people and it avoided any pull factors at that part of Bangladesh. Most importantly, the area was kept quite underdeveloped than the average other parts of the country. GoB was against any kind of self-reliant activities even for the registered refugees, whatever the limited scope was offered from the NGOs, those were also halted shortly. Registered refugees, however, had a scope to resettle in a third country but that was also suspended in 2010 (ZETTER - RUAUDEL 2016). To Put it differently, the few who received the (quite) proper label, GoB did not execute the amenities further because those were identified as pull factors of further Rohingya flow. The Rohingya are treated in a temporary and intermediate manner however some of them from the first influx have spent several decades in exile in Bangladesh. Most of the Southeast and South Asian countries are the parties of many 
other human rights frameworks such as Universal Declaration of Human Rights of 1948, International Covenant on Economic Social and Cultural Rights (ICESCR) and the International Covenant on Civil and Political Rights (ICCPR). Those countries can preserve refugees' human rights under these legal bindings but state sovereignty over nationality constraints their application to a great extent (ADJAMI - HARRINGTON 2008).

Since the adoption of UN refugee convention, the refugee regime is considered as a western brainchild and the labeling alike in the twenty-first century. Labeling in the global north has a trickle-down effect on the host countries in the global south, although South Asia has a long history of rejection of refugee policy (BEHRMAN 2019; DAVIES 2006). The region has many experiences of hosting refugee and sanctuary of lives. A similar situation happened to forcibly displaced people from the then East Pakistan (Bangladesh) to India, present day refugee from Myanmar to Thailand and so on. None of them were granted refugee status. However, such state-centric actions cannot bring forth any benefits for the host countries rather those actions exacerbate the vulnerabilities of the already vulnerable people. In this situation, refugees are captured in the state of exception' (AGAMBEN 1998) in which the host government can exercise legal action against them even though refugee-like people cannot avail any rights legally. Consequently, the Rohingya people in the camps in Bangladesh are controlled, excluded from the host community, and ended up in a more vulnerable situation. Besides, many other hierarchical labelings have created much discrimination among the different categories of the Rohingya people. Thus, host countries apply such labelling to avoid their responsibilities to so-called aliens' human rights and protection. Labeling acts as an effective tool in the fortress of nation-state and eventually securitization of forcibly displaced people.

\section{Implications of labeling}

It can be said from the above findings that the labeling of Rohingya people has presented many human rights implications. It did not strike the non-refoulement principle and deportation cases, but it affected some very basic services and rights as a human beings. It is evident that with refugee status, they could receive sufficient aid, good shelter, enjoy more agencies and exert power over other Rohingya people in the camps at least until 2017. In extended periods some other adjacent areas of Teknaf and Ukhiya of Cox's Bazar were also in their movement radius. Registered refugees were also in de facto local integration with some self-reliance opportunities in the protracted situation, (UNHCR 2007). They were not restricted to mix, marry and join with local people and eventually many of them managed to acquire a Bangladeshi national identity card as well (ZETTER - RAUADEL 2016). There was an 
unofficial signal to those Rohingya people for assimilation in the local community as an ending of the Rohingya crisis in Bangladesh until the last largest influx.

On the other hand, the scale of vulnerability of UMNs was higher than that of recognized Rohingya refugees in Bangladesh. They had no right to work and were to manage their own livelihoods. They were the prime victims of labor exploitation, sexual exploitation, and human trafficking. Eventually, IOM provided humanitarian support of food, shelter and documentation to some extent until 2017. The classification of the Rohingya people as registered refugees and UMNs, sometimes causes more consequences than suffering the monsoon in Kutupalong camp (SULTANA 2019). In the light of this reality, UMNs avoided approaching law enforcement agencies even when serious crime was committed against them (IOM 2016).

The condition of the Rohingya people drastically worsened due to the new influx or since the addition of FDMN to the demography. They live in a very unhygienic, overcrowded and cramped condition (BBC 2018; GHOSH 2018). Tellingly, they cannot move outside the camps at all, no permission of assembly, no access to mobile phones or the internet. The depoliticization move of the GoB, deters the Rohingya people from participating in the decisionmaking process of their very own issues. The Rohingya people are not only excluded from the local people legally and social, but also razor wire fencing is being erected very fast for physical distance (Author's observation 2019). FDMNs have no legal support in Bangladesh, although it is a signatory of many international covenants of human rights. The Universal Declaration of Human Rights (UDHR) declares that everyone has the right to seek and to enjoy other countries' asylum from persecution (UDHR 1948: Art 14). Article 7 of the United Nations Convention on the Rights of the Child obliges the state parties to implement the registration process of a child immediately after its birth. The CEDAW article 9 supports women's rights along with the nationality of their children whereas Article 24 of International Covenants on Civil and Political Rights calls for the nationality rights of every child. Unfortunately, the UN bodies cannot enforce these Human Rights Laws for every individual because these are mostly applicable to a citizen of State. The UDHR also emphasizes on nationality and citizenship of the people (WEISSBRODT - COLLINS 2006). Both Myanmar and Bangladesh ignore the human rights of Rohingya people in 'us and others' discourse which is happening now and then in the international state system (ROY 2020). Labeling is applied just as a hyper technique. The effects of labeling to human rights of Rohingya people can be compared in the following figure (Figure 11). 


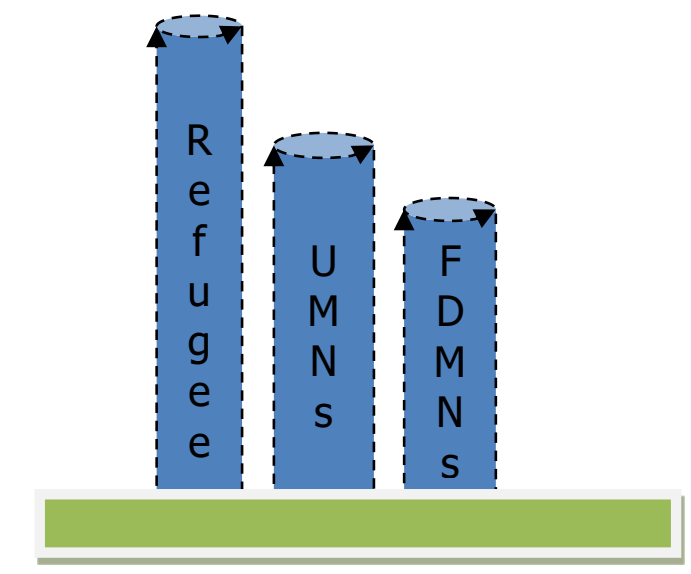

Figure 11: Human rights among the Rohingya people Source: The author

Rohingya people cannot demand rights from the GoB, so they have to face the unexpected consequences. The state authority oftentimes justifies its activities by hosting millions of Rohingya people for an extended period. Tellingly, labeling is decaying their agencies on one hand while inequality and deprivations among the Rohingya are generating security challenges for the host country as well the region as a whole on the other.

\section{Conclusion and Recommendation}

By labeling the Rohingya people in different statuses has considerable effects on their human rights. Some of them with refugee status used to enjoy freedom of movement to some extent and livelihood. They began to live meaningful lives. UMNs in the case of the Rohingya people, however, had some uncertainties about their life and livelihood; they could enjoy more freedom than with the status of FDMNs (CHEUNG 2011). Except for the very basic needs of food, shelter, water-sanitation and health services, the issue of freedom of speech, right to work and freedom of movement are beyond negotiation for FDMNs. These stratifications and labeling are causing discrimination and deprivations among the Rohingya people at large (SULTANA 2019). Therefore, finding the labeling a political issue, this study recommends the competent authority to consider their human rights as a human being, without labeling them in different categories. Since refugee or these forcibly displaced people have crossed the international border, international organizations such as the UN, ASEAN, and other humanitarian organizations need to play their part strongly in the solution of the crisis. To that end, international actors can consider creating a safe zone in the Rakhine state of Myanmar under the direct supervision of the UN and obligatory burden-sharing for every member state of the UN for refugees around the globe including Rohingya refugees. The UN and other regional state associations should come forward in support of adopting individual refugee 
policy for South Asian countries as well because the minimum human rights of refugees- like people can be preserved with refugee status.

It is quite challenging to implement these recommendations but that will reduce the refugee crisis to a great extent. Firstly, because of the safe zone and UN intervention inside the source country, it will be more effective in safeguarding the human rights of the targeted group of people. Secondly, even if any of the flight of people crossed a border, every UN member state would have to bear the burden of humanitarian provisions proportionately until their repatriation to the country of origin. Thus, it can create strong international pressure on the country of origin and will think seriously before any persecution against minority people. Thirdly, by having refugee status, they can enjoy the minimum human rights in the host country. The upshot of this is that there are sufficient international legal frameworks to address such recommendations; it is now a matter of enforcement and a way of implementation. Undoubtedly, the fulfillment of human rights of these hundreds of thousands of Rohingya people is the prerequisite of security and sustainable development of the region as well.

\section{Acknowledgement}

An earlier version of this study was presented in the Online $9^{\text {th }}$ Interdisciplinary Doctoral Conference (IDK2020) held in 27-28 November, 2020 in the University of Pécs, Hungary. Thanks to the conference session chair for his valuable comments.

\section{References}

ADJAMI. M. - HARRINGTON. J. 2008: The Scope and Content of Article 15 of the Universal Declaration of Human Rights. Refugee Survey Quarterly, 27(3): pp. 93-109.

AGAMBEN, G. 1998: Homo Sacer: Sovereign power and bare life. California: Stanford University Press.

AHSAN ULLAH, A. K. M. 2016: Rohingya crisis in Myanmar: Seeking justice for the “stateless". Journal of Contemporary Criminal Justice 32(3): pp. 285-301.

AMIT, R. 2019: Reclaiming Refugee Rights as Human Rights. Pace International Law Review 31(2): pp. 557-561.

BIGD (Brac Institute of Governance and Development). 2018: Self-Reliance Situation of Host Communities in Cox's Bazar. Commissioned by Save the Children, Brac, World Vision, WFP and UNHCR.

BEHRMAN, S. 2019: Laws of Asylum and Protection: The Indian Experience in a South Asian Context. Refugee watch 15: pp. 15-28. 
BJORNBERG, A. 2016: Rohingya Territoriality in Myanmar and Bangladesh: Humanitarian Crisis and National Disordering. Myanmar's Mountain and Maritime Borderscapes: Local Practices, Boundary-Making and Figured Worlds, p.146.

BBC. 2018: Myanmar Rohingya: What you need to know about the crisis. 24 April 2018. Retrieved from: https://www.bbc.co.uk/news/world-asia-41566561 [Accessed on 18 July 2018]

CHEUNG, S. 2011: Migration control and the solutions impasse in South and Southeast Asia: Implications from the Rohingya experience. Journal of Refugee Studies 25(1): pp. 50-70.

CHIMNI, B. S. 2004: From resettlement to involuntary repatriation: towards a critical history of durable solutions to refugee problems. Refugee Survey Quarterly 23(3): pp. 55-73.

DAVIES, S. E. 2006: The Asian rejection? International refugee law in Asia. Australian Journal of Politics \& History 52(4): pp. 562-575.

GHOSH, B. 2018: Refugee and Mixed Migration Flows: Managing a Looming Humanitarian and Economic Crisis. Geneva: Palgrave Macmillan.

LOESCHER, G. - MILNER, J. H. 2008: Burmese refugees in South and Southeast Asia: A comparative regional analysis, in LOESCHER, G. - MILNER, J., - NEWMAN, E. (eds.). Protracted refugee situations: Political, human rights and security implications. Tokyo: UN University Press.

GUHATHAKURTA, M. 2017: Understanding violence, strategizing protection: perspectives from Rohingya refugees in Bangladesh. Asian journal of social science 45(6): pp. 639-665. GRUNDY-WARR, C. - WONG, E. 1997: Sanctuary under a plastic sheet-the unresolved problem of Rohingya refugees. - IBRU Boundary and Security Bulletin 5(3): pp. 79-91.

HUMAN RIGHTS WATCH 2018: Bangladesh is not my country: the plight of Rohingya refugees from Myanmar. Retrieved from: https://www.hrw.org/sites/default/files/report_pdf/bangladesh0818_web2.pdf (Accessed on 18 July 2018)

IBRAHIM, A. 2016: The Rohingyas: Inside Myanmar's Genocide. London: Hurst \& Company. INTERNATIONAL ORGANIZATION FOR MIGRATION (IOM). 2016: A needs assessment of UMNs population and capacity assessment of service providers in makeshift settlements with a focus on Sex and Gender Based Violence (SGBV). Dhaka: International Organization for Migration.

KIRAGU, E. - ROSI, A. L. - MORRIS, T. 2011: States of denial: A review of UNHCR's response to the protracted situation of stateless Rohingya refugees in Bangladesh. Policy Dev. Eval. Serv. UNHCR. 
LEE, J. S. - NERGHES, A. 2018: Refugee or migrant crisis? Labels, perceived agency, and sentiment polarity in online discussions. Social Media+ Society 4(3): pp. 1-22.

MEDICINS SANS FRONTIERES (MSF). 2002: 10 Years for the Rohingya refugee in Bangladesh: Past, present and future. Retrieved from: https://www.msf.org/ten-yearsrohingya-refugeespast-present-and-future-report-summary [Accessed on 15 July 2020]

PARNINI, S. N. - OTHMAN, M. R. - GHAZALI, A. S. 2013: The Rohingya refugee crisis and Bangladesh-Myanmar relations. Asian and Pacific Migration Journal 22(1): pp. 133146.

RAHMAN, U. 2010: The Rohingya refugee: A security dilemma for Bangladesh. Journal of Immigrant \& Refugee Studies 8(2): pp. 233-239.

ROY, S. 2020: Statelessness of Myanmar's Rohingya Ethnic Population: Assessing the Role of International Community. Social Science Review, 37(1): pp. 277-294. University of Dhaka, Bangladesh.

SERUGHETTI, G. 2018: Smuggled or Trafficked? Refugee or job seeker? Deconstructing rigid classifications by rethinking women's vulnerability. Anti-trafficking review (11).

SMITH, M. 1999: Burma: Insurgency and the Politics of Ethnicity. London: Zed.

SULTANA, I. Z. 2019: Rohingyas in Bangladesh: Owning Rohingya Identity in Disowning Spaces. Ontario: York University.

THE DAILY STAR 2017: Forcibly displaced Myanmar nationals.- Retrieved from: https://www.thedailystar.net/city/forcibly-displaced-myanmar-nationals-1469374 (Accessed on 10 June 2018)

THE GOVERNMENT OF BANGLADESH 2020: Humanitarian Assistance for Forcibly Displaced Myanmar Nationals (in Bengali). Retrieved from: https://modmr.gov.bd/sites/default/files/files/modmr.portal.gov.bd/page/fc7d8708_a0b7 4a2f_acf4_df4824384398/Rohingya_at\%20a\%20glance.pdf (Accessed on 10 March 2021) THE GOVERNMENT OF BANGLADESH 2014: National strategy paper on Myanmar refugees and undocumented Myanmar Nationals in Bangladesh.

TÜRK, V. - DOWD, R. 2014: Protection gaps. The Oxford handbook of refugee and forced migration studies. London: Oxford University Press. pp. 278-289.

UNHCR 2007: Bangladesh: Analysis of Gaps in the Protection of Rohingya Refugees.Retrieved from: https://www.unhcr.org/46fa1af32.pdf (Accessed on 10 January 2020)

UNHCR 2011: State of Denial: a review of UNHCR's response to the protracted situation of stateless Rohingya refugees in Bangladesh. 
UNHCR. 2013: UNHCR Global Appeal 2012-2013. Retrieved from: https://www.unhcr.org > en-my/pdf

UNHCR. 2018: Towards a global compact on refugees. Retrieved from: http://www.unhcr.org/towards-a-global-compact-on-refugees.html [Accessed on 18 July 2018]

UNHROHC. 2021. What are human rights? Retrieved from: https://www.ohchr.org/en/issues/pages/whatarehumanrights.aspx [Accessed on 5 March 2021]

WADE, F. 2017: Myanmar's enemy within: Buddhist violence and the making of a Muslim 'other'. London: Zed Books Ltd.

WEISSBRODT, D. - COLLINS, C. 2006: The human rights of stateless persons. Human Rights Quarterly 28: pp. 245-276.

VIGIL, Y. N., - BAILLIE ABIDI, C. 2018: "We" the Refugees: Reflections on Refugee Labels and Identities. Refuge. Canada's Journal on Refugees/Refuge: 34(2): pp. 52-60.

VINCE, G. 2020: The world's largest refugee camp prepares for covid-19. Bmj, 368. Retrieved from:

https://www.alnap.org/system/files/content/resource/files/main/bmj.m1205.full_.pdf (Accessed on 7 May 2020)

ZETTER, R. - RUAUDEL, H. 2016: Refugees' right to work and access to labor markets-An assessment. World Bank Global Program on Forced Displacement (GPFD) and the Global Knowledge Partnership on Migration and Development (KNOMAD) Thematic Working Group on Forced Migration. KNOMAD Working Paper. Washington, DC: World Bank Group.

ZETTER, R. 2007: More labels, fewer refugees: Remaking the refugee label in an era of globalization. Journal of refugee studies 20(2): pp. 172-192.

ZETTER, R. 1991: Labeling refugees: Forming and transforming a bureaucratic identity. Journal of refugee studies 4(1): pp. 39-62. 


\title{
Can international organisations save the environment? - The response of the Council of Europe to the global environment crisis Adrienn TÓTH-FERENCI ${ }^{55}$
}

\begin{abstract}
Amid the dynamism of international relations, the role and place of the international organisations in the system has received particular attention in recent years. Geopolitical events regularly challenge the multilateral institutions on the one hand, but transnational threats require strengthened cooperation on the other. The COVIDpandemic is not the only global problem that calls for international partnership. Environmental aspects of common actions in international fora are attracting increasing attention within societies and at global level, too. In the meantime, multilateral institutions strive to be proactive to show their efficiency, relevance and added value. In a similar spirit, the Council of Europe is also developing its mechanisms to respond to the global environmental crisis.

The paper aims to illustrate the dilemma concerning the future role of the Council of Europe in the light of environmental challenges by applying an empirical approach and seeks to obtain an answer to this question through a case study. To obtain the most comprehensive and holistic picture possible, a qualitative analysis is planned, which will examine the responses of the Council of Europe to the environmental crises. The results of this analysis may serve to enrich the general literature on multilateral organisations, as well as contribute to the body of research concerning the future place of multilateral cooperation in today's globalised world.
\end{abstract}

Keywords: multilateralism, transnational threat, environment crisis, Council of Europe, World Forum for Democracy

\section{Introduction}

The main feature of the international order after World War II is the appearance of international organisations that introduced new questions in the field of international relations, namely the issue of integration, multilateralism, national competence, or supranationalism. New theories have been developed to describe the new phenomenon of European integration, to understand and possibly tackle the challenges of formal international cooperation.

The history of the Council of Europe ${ }^{56}$ as an intergovernmental organisation forms an integral part of the political context after the World War II. It perfectly reflects the waves of the European integration process, the clash of renewable theories with political reality, the struggle between federalists and the supporters of national sovereignty, the division of the continent within a bipolar international system or the alternations of "small" and "great" Europe concepts (GAZDAG 1999, p. 14).

It is almost a cliché to say that multilateralism faces serious challenges now, but neither the analysis of the main tenets of multilateralism nor the assessment of factors leading to the weakening commitments of states to intergovernmental organisations are within the focus of

\footnotetext{
${ }^{55}$ Corvinus University of Budapest, Doctoral School of International Relations and Political Science, PhD Candidate, Chief of the Ministerial Commissioner's Cabinet responsible for the Development of Neighbourhood Policy of Hungary, Ministry of Foreign Affairs and Trade. aferenci@mfa.gov.hu

${ }^{56}$ Hereinafter referred to as CoE.
} 
this paper. The current study limits itself to describing the trend whereby international cooperation in the field of environmental protection has increased in the recent decades, with a particular focus on the environment-related issues in the Council of Europe. It also seeks answers to these questions: how, concretely, the Council of Europe may respond to the global environmental crisis, and how the Council of Europe might strengthen international cooperation to save the environment.

\section{Transnational challenges}

The Council of Europe, in a manner similar to other regional intergovernmental cooperation frameworks, has always paid particular attention to the changes taking place in the world and has adapted its responses and mechanisms to a fast-moving world. The Organisation showed that it was ready to assume a new mission and responsibility at the time of democratic transition of the Central and East European countries by developing new institutional structures $^{57}$ and it also reacted rapidly to the appearance of terrorism shocking the US and the world in 2001. At that time, the Council of Europe reinforced its activity in the field of counterterrorism and elaborated a new legal instrument to assist the global efforts against terrorism. ${ }^{58}$

The migration influx which peaked in 2015 also provoked a rapid reaction. The Secretary General established the institution of special representative on migration and refugees to give an answer to the humanitarian crisis, as well as to provide assistance and support to the member states concerned (MANDATE, SPECIAL REPRESESENTATIVE ON MIGRATION 2020).

The current pandemic is a manifestation of another transnational threat and the answers given to the situation by the intergovernmental organisations reflect the expectation that multilateral institutions be actively involved in the crisis management. Indeed, their contribution based on general values set in legally binding instruments such as the Convention for the Protection of Human Rights and Fundamental Freedoms ${ }^{59}$ seems to be conducive to strengthening cooperation among international actors so that they may overcome the pandemic successfully.

\footnotetext{
${ }^{57}$ The CoE developed numerous new structures and institutions, such as the European Commission against Racism and Intolerance, the Commissioner for Human Rights, or the European Commission for Democracy through Law, commonly known as Venice Commission in the 1990s.

${ }^{58}$ The Council of Europe has adopted the Convention on the Prevention of Terrorism to increase the effectiveness of existing international texts on the fight against terrorism.

59 The Council of Europe Convention entered into force in 1953. It sets forth a number of fundamental rights and freedoms, including the right to life, prohibition of torture, right to liberty and security, right to a fair trial, freedom of thought, conscience and religion, freedom of expression, freedom of assembly and association, right to an effective remedy, prohibition of discrimination. Hereinafter referred to as ECHR.
} 
Conversely, when the international community confronts geopolitical, geostrategic types of challenges, such as the war between Georgia and Russia in 2008 (PACE RESOLUTION 1633 2008), or the annexation of Crimea by the Russian Federation in 2014 (PACE RESOLUTION 1988 2014), the human rights and rule of law based intergovernmental organisations entirely lack the means to influence events in a substantial manner. ${ }^{60}$

Taking into account the above, it seems that the efficiency of multilateralism should be analysed from different angles and there is no obvious answer in today's interconnected and interdependent world with multiple actors.

When the Council of Europe was founded in 1949, the primary goal was to achieve a greater unity between its members, to safeguard and realise the ideals and principles of a common European heritage and to facilitate economic and social progress (PREAMBLE, STATUTE OF THE COUNCIL OF EUROPE 1949). Following this objective and mandate, the Council of Europe systematically elaborated a normative regulatory scheme with fundamental human rights treaties. The mission of the Organisation at the time of the foundation was to discuss "questions of common concern and... [to conclude] agreements and common action in economic, social, cultural, scientific, legal and administrative matters and in the maintenance and further realisation of human rights and fundamental freedoms." (ARTICLE 1, STATUTE OF THE COUNCIL OF EUROPE 1949). The aim to develop the normative basis for a single European legal area in the field of human rights, democracy and rule of law appeared a few decades later when the Council of Europe assumed its role in preparing the new democracies of Eastern Europe to comply with the international standards after the collapse of the Soviet Union in the 1990s. ${ }^{61}$ In the 1990s the role of these values become much more significant since the European integration process needed solid democratic and human rights architecture, a stable system of rule of law as well. ${ }^{62}$ Accordingly, the Council of Europe defines itself as the continent's leading human rights organisation and its tools are mainly regulatory instruments, advisory organs and independent institutions with complex monitoring functions in most of the cases. The more than two hundred conventions, the European Court of Human Rights, the European Commission against Racism and Intolerance, the Commissioner for Human Rights, the European Commission for Democracy through Law are intended, first and foremost, to guarantee fundamental human rights and all other, newer types of challenge are always observed through the prism of human rights. In contrast to the United Nations, whose

\footnotetext{
${ }^{60}$ Author's opinion

${ }^{61}$ Author's opinion

${ }^{62}$ Preamble and in Article 2 of the Treaty on European Union.
} 
more global character and membership empowers the Organisation to be more efficient in coordinating international actions against global challenges, the Council of Europe places its focus on the human rights and standard-setting aspects of the transnational challenges. These conditions determine the extent to which the Council of Europe may answer global threats. On the one hand, they make it possible to elaborate a comprehensive and unique normative scheme in relation to the environment; on the other hand, the human rights approach limits the scope of its field of possible concrete actions.

\section{Environment in the forefront of international cooperation}

\subsection{From the very beginning}

This chapter aims to provide a general overview on the milestone events leading to an institutionalised environmental cooperation at a global level and does not seek to provide an exhaustive, chronological analysis. Given the global nature of the threats to environment, the United Nations was the first international organisation addressing the new challenges. The Stockholm Declaration on the United Nations Conference on the Human Environment adopted in 1972 can be regarded as the starting point of a rights-based approach to environmental protection (UNITED NATIONS REPORT 1972). It formulated the principle that "Man [should] have the fundamental right to freedom, equality and adequate conditions of life, in an environment of a quality that permits a life of dignity and well-being, and he bears a solemn responsibility to protect and improve the environment for present and future generations" (UNITED NATIONS REPORT 1972, p. 4).

As the professor of history, Jacobus A. DU PISANI pointed out, the conference was preceded by a period of an immense scientific and technological progress that caused terrible damage to the natural environment. By the 1970s, people recognised the threats that rapid population growth, pollution and resource depletion posed to the environment. Ecological disasters were widely reported in the press, the green movement was launched, the first environmental non-governmental organisations were set up and environmental concern became more acute and radical because of the fear that economic growth might endanger the survival of the human race and the planet (DU PISANI 2006, pp. 83-96). When explaining the historical context of sustainable development DU PISANI writes that "This alarmist mood, in expectation of an imminent ecological catastrophe, stimulated a new mode of thinking about development and prepared the way for sustainable development as an alternative to unlimited economic growth” (DU PISANI 2006, p. 89). 
Thus, the economic development, its negative impact on the environment and other worrying trends of the rapid progress, the protection of environment came into the foreground in the 1970s and 1980s. The first major and widely known report of the Club of Rome, the Limits to Growth also examined the impact of economic development on nature by assessing industrial output and pollution. As the report highlights "With world population doubling time a little more than 30 years.... on both sides of the man-environment equation, the situation will tend to worsen dangerously. We cannot expect technological solutions alone to get us out of this vicious circle. The strategy for dealing with the two key issues of development and environment must be conceived as a joint one" (MEADOWS et al. 1972, p. 192).

In the light of the growing need to tackle the problems, the United Nations, the European Community, and the Council of Europe also responded to this emerging, new type of challenge, which induced legislative initiative and more focused international cooperation. The UN General Assembly decided to establish a World Commission on Environment and Development $^{63}$ (UNGA RESOLUTION 38/161 1983) to formulate a global agenda for change to propose long-term environmental strategies and to consider the means how the international community can address more effectively the environment concerns (BRUNDTLAND REPORT 1987, p. 6). The UN General Assembly also decided to establish the United Nations Environment Programme with the aim "to promote international co-operation in the field of the environment and to recommend, as appropriate, policies to this end" (UNGA RESOLUTION 2997 1972). The World Commission chaired by Gro Harlem Brundtland identified many industrial, environmental accidents from Mexico City, India, the USA but serious disasters were reported on the European continent, in Basel or Seveso, Italy (ESKENAZI et al. 2018), too, not forgetting the nuclear catastrophe in Chernobyl (BRUNDTLAND REPORT 1987 p. 156).

The report served as a background for the 1992 UN Conference on Environment and Development (also known as the Earth Summit) ${ }^{64}$, which produced the Rio Declaration on Environment and Development (RIO DECLARATION 1992). The declaration (also called Agenda 21) was a plan of action to be taken on globally, nationally, and locally by governments, organisations, and individuals in every area in which human beings have an impact on the environment.

\footnotetext{
${ }^{63}$ The Commission was named after its chairperson, Ms. Gro Harlem Brundtland, former Prime Minister of Norway. https://unfoundation.org/who-we-are/our-board/gro-harlem-brundtland-norway-vice-chair/

${ }^{64} \mathrm{https}$ ://sustainabledevelopment.un.org/milestones/unced
} 
The actions above led to the Millennium Summit ${ }^{65}$ of the United Nations in 2000, when the heads of state and government adopted the Millennium Development Goals, with a view to ensuring environmental sustainability as part of the issues (UNGA RESOLUTION 55/2 2000).

The industrial disasters and economic expansion also prompted the European Community to develop legislation with a view to preventing similar catastrophes. The environment policy in the Community dates back to 1972 when political leaders decided to launch environment action programmes. The so-called Seveso-Directive (COUNCIL DIRECTIVE 82/501/EEC 1982) was adopted following the chemical accident in Italy but it was later amended in view of the lessons learned from later accidents resulting into Seveso-II (COUNCIL DIRECTIVE 96/82/EC 1996). The first legal basis for a common environment policy was developed in the Single European Act in 1987 but subsequent treaty revisions strengthened the Community's commitment to environmental protection. The Treaty of Maastricht of 1993 made the environment an official EU policy area, while the Treaty of Amsterdam in 1999 "established the duty to integrate environmental protection into all EU sectoral policies with a view to promoting sustainable development" (FACT SHEETS ON THE EUROPEAN UNION 2021). In 2012 Seveso-III (DIRECTIVE 2012/18/EU 2012) was adopted taking into account, amongst others, the changes in the Union legislation on the classification of chemicals and increased rights for citizens to access information and justice" (EUROPEAN COMMISSION, ENVIRONMENT 2021). ${ }^{66}$

"Considering the very high rate of industrialisation in the European Union the Seveso Directive has contributed to achieving a low frequency of major accidents. The Directive is widely considered as a benchmark for industrial accident policy and has been a role model for legislation in many countries world-wide" (EUROPEAN COMMISSION, ENVIRONMENT 2021).

The current legal basis for the environment policy of the European Union is enshrined in the Treaty on the Functioning of the European Union emphasising that the Union environment policy aims at "preserving, protecting and improving the quality of the environment, protecting human health, prudent and rational utilisation of natural resources, promoting measures at international level to deal with regional or worldwide environmental problems, and in particular combating climate change" (TREATY, EU 2012, Article 191).

\footnotetext{
${ }^{65} \mathrm{https://www.un.org/en/events/pastevents/millennium} \mathrm{summit.shtml,} \mathrm{retrieved} \mathrm{on} 6$ March 2021.

${ }_{66}$ Major accident hazards, The Seveso Directive - Technological Disaster Risk Reduction, https://ec.europa.eu/environment/seveso/, retrieved on 6 March 2021.
} 
Although the environmental disasters resulted in extensive litigation, neither future generations nor the environment are ever represented in court cases. Thus, Polly Higgins, an environmental lawyer proposed to the United Nations that ecocide be recognised as an international Crime Against Peace alongside Genocide, Crimes of Humanity, War Crimes and Crimes of Aggression, to be brought before the International Criminal Court. Higgins defined ecocide as "The extensive damage to, destruction of or loss of ecosystems of a given territory, whether by human agency or by any other causes, to such an extent that peaceful enjoyment by the inhabitants of that territory has been severely diminished" (HIGGINS et al. 2013, p. 257).

To conclude the presentation of the main achievements of international cooperation it should be recalled that, due to the joint efforts in the international climate policy the first, legally binding international treaty on climate change was adopted in 2015. The Paris Agreement, which entered into force on 4 November 2016, aims to limit global warming by targeting a global peak level of greenhouse gas emissions, with a view to achieving a climate-neutral world by mid-century (PARIS AGREEMENT 2015, Article 4).

\subsection{Environmental issues at the agenda of the Council of Europe}

The Council of Europe has also recognised the importance of environment protection since the 1970s. To protect nature, the Convention on the Conservation of European Wildlife and Natural Habitats, commonly known as Bern Convention, was drafted in 1979 with a view to promoting national conservation policies through regional planning policies and pollution abatement (COE CONVENTION ETS 104, 1979).

After the major disasters of the 1980s, the Organisation decided to set up a Co-operation Group for the prevention of, protection against, and organisation of relief in major natural and technological disasters. The objective of the "group shall be to make a multidisciplinary study of the co-operation methods for the prevention of, protection against, and organisation of relief in major natural and technological disasters" (CM RESOLUTION (87)2, 1987). Another aim of the EUR-OPA Major Hazards Agreement was to develop new methodologies and tools for efficient risk management. To meet the major challenges posed by natural and technological hazards, the Agreement launched innovative action to promote a greater risk culture within the population, as well as better management of disaster situations by all responsible authorities (FACING RISK TOGETHER, CoE 2010).

The legislative activity continued in the Council of Europe leading to the adoption of the Convention on Civil Liability for Damage Resulting from Activities Dangerous to the Environment in 1993, to ensure adequate compensation for damage resulting from activities 
dangerous to the environment, while also providing for means of prevention and reinstatement. As a further step, the Convention on the Protection of Environment through Criminal Law was also adopted in 1998. This convention aimed at a better protection of the environment by using the solution of last resort, the criminal law, for deterring and preventing conduct, which is most harmful to it (EXPLANATORY REPORT 1998, p. 2). The Landscape Convention was concluded in 2000 to promote landscape protection, management, and planning, and to organise European co-operation on landscape issues (COE CONVENTION ETS 176. 2000). Besides this standard-setting activity, there have been several efforts by the Parliamentary Assembly of the Council of Europe to add the right to a healthy environment to the European Convention on Human Rights. The Assembly referred to Principle 1 of the 1972 Declaration of the United Nations Conference on the Human Environment (REPORT, UNITED NATIONS 1972) and the conventions mentioned above, when arguing to draft an additional protocol to the ECHR concerning the right to a healthy environment (PACE RECOMMENDATION 1885 2009).

Individuals and international fora are increasingly aware of the fact that environment related questions have serious impact on fundamental human rights. The European Convention for the Protection of Human Rights and Fundamental Freedoms and the European Social Charter have no explicit reference to the right to a healthy environment, however, both instruments indirectly contain a certain degree of protection with regards to environmental matters through the case-law of the European Court of Human Rights and the European Committee on Social Rights, as the intergovernmental Steering Committee on Human Rights ${ }^{67}$ clearly stated (COE ENVIRONMENT PROTECTION 2021, p. 42). "Both the Court and the Committee have emphasized the evolutive nature of both instruments. The Convention and the Charter are living instruments, which, in order to effectively protect, need to be interpreted in light of present-day conditions. Such conditions are considered to include the current environmental crisis" (COE ENVIRONMENT PROTECTION 2021, p. 42).

New impetus was given to the normative efforts of the Council of Europe in the field of environment and human rights after the unprecedented Amazon rainforest wildfire and the Australia bushfires in 2019. The European Court of Human Rights also delivered a new, an emblematic judgement in a case where the environmental pollution endangered the health of the applicants (ANNUAL REPORT, ECtHR 2020). To respond to the urgent needs, the Committee of Ministers of the Council of Europe decided on 19-21 November 2019 to instruct its steering committee on human rights to update the Handbook on Human Rights and the

\footnotetext{
${ }^{67}$ Hereinafter referred to as $\mathrm{CDDH}$ (Comité directeur pour les droits de l'homme), intergovernmental expert committee of the Committee of Ministers.
} 
Environment ${ }^{68}$ and, to develop a draft non-binding instrument of the Committee of Ministers recalling existing standards in this field for the 2020-2021 biennium (PROGRAMME AND BUDGET 2020-2021, CDDH 2019). To streamline the resources and capacity, the Steering Committee for Human Rights decided to set up a Drafting group on Human Rights and Environment (CDDH-ENV) at its plenary meeting held on 27-30 November 2020 (STEERING COMMITTEE FOR HUMAN RIGHTS 2020, p. 16). At its subsequent plenary meeting the new working group was tasked with the update of the Manual on Human Rights and the Environment, as well as the compilation of the draft non-binding legal instrument on human rights and environment. Besides, the new subgroup was also instructed to "consider the need for further work in this field, bearing in mind the obligations of the member States under the European Convention on Human Rights and the steady development of the case-law by the European Court of Human Rights and national courts that foster the interconnection between the protection of the environment and human rights" (TERMS OF REFERENCE 2020).

While the case-law of the European Court of Human Rights reacts more and more frequently to the environmental aspects, the first climate change application has been only lodged with the Court in the autumn of 2020. "The case concerns greenhouse gas emissions, which are believed to be contributing to global warming and manifested, among other things, by heat waves which would impact the living conditions and heath of the applicants. The applicants, aged between 8 and 21 years, claim that the forest fires that Portugal has experienced every year for several years, in particular since 2017, are the direct result of global warming to which such emissions have contributed." 69 The applicants' case was submitted against 33 member-states of the Council of Europe. ${ }^{70}$

\section{World Forum for Democracy}

The Council of Europe always seeks the most suitable structures and mechanisms to ensure its visibility on the one hand, and to promote Council of Europe principles across the world, on the other. The World Forum for Democracy was initiated in 2012 as a platform for dialogue and innovation in democratic governance. The annual event is co-organized by the Council of Europe, the European Parliament, the French authorities, the regional authorities of

\footnotetext{
${ }^{68}$ Manual on Human Rights and the Environment, Council of Europe Publishing, First edition 2006, second edition 2012. https://rm.coe.int/09000016806962d1, retrieved on 30 May 2021.

${ }^{69}$ Protecting the environment using human rights law, CoE Website, https://www.coe.int/en/web/portal/humanrights-environment, retrieved on 30 May 2021.

${ }^{70}$ Cláudia Duarte Agostinho et autres contre le Portugal et 32 autres États introduite le 7 septembre 2020, Requête no 39371/20, https://hudoc.echr.coe.int/eng\#\{\%22itemid\%22:[\%22001-206535\%22]\}, retrieved on 30 May 2021.
} 
Grand Est and the City of Strasbourg (A LOOK INSIDE 2016). The World Forum is a thematic event, the Forum addresses the key challenges each year with the involvement of government and parliamentary level, the civil society and private sector, academia, and youth. Since 2012, the Forum addressed among others the issue of old models and new realities of democracy, the challenges of the digital age, the participation of youth in revitalising democracy, the dilemma of freedom versus control in the context of the migration crisis, as well as the problem of equality, populism, or the information age.

The World Forum is not an institutionalised framework, rather a flexible, international floor where the stakeholders could exchange their views, build on the experience of the others and could elaborate recommendations to all level, from the governments, parliaments and political parties, through civil society and private sector to the international organisations (WORLD FORUM FOR DEMOCRACY 2018).

The Forum is the eloquent example for reducing the transaction cost of coordination, the feature often referred to as an argument by the supporters of the institutionalist theory of international relations. According to Graham Allison, the challenges of the current world such as terrorism, drug trafficking and pandemics are the evidence that states can no longer react unilaterally to these threats, but global collaboration is needed (ALLISON 2000, p. 84).

\section{Can Democracy save the environment?}

The global pandemic reached Europe at the beginning of 2020 and redirected the attention to the global threats, to the interdependence, to the importance of cooperation and common responsibility. The societies recognised at global level to what extent we are interconnected. The lessons were drawn, and the World Forum will respond to the world events this year. The conference is exceptional this year also in terms of organisation, as the first event of the program was launched already last November with the aim that that through the campaign " 12 months, 1 question" could focus on one topic related to the question "Can democracy save environment?" The ninth Forum is therefore organised in three parts: the formal launching on 18 November 2020, the 12 month-long series of events to be accessible on the WFD website (November 2020 - November 2021) and a 3-day live in-person event in November 2021.

According to the concept note, the Forum seeks the answer to the question, who is responsible for the environmental protection. The national governments, international organisations or the citizens are the actors who are setting the scene? "What is preventing governments from taking more radical steps? Perhaps they are influenced by business and 
economic interests, or by the demand for increased investment of public money in other areas ranging from infrastructure to pensions to public services" (WORLD FORUM FOR DEMOCRACY 2020). The experience of crisis management during the global pandemic raised the issue of the most suitable government approach to efficiently tackle the environmental challenges and the burden sharing between the public and private sector, is also a question that the $9^{\text {th }}$ Forum intends to answer.

Given that the relevance and added value of the Council of Europe derive from standardsetting activity, the World Forum for Democracy can be considered rather as an awarenessraising tool to direct the attention of all stakeholders, ranging from government to the civil sphere, to the importance of the issue. This spectacular international gathering will spotlight the environment-related challenges and place the issue on the political agenda of the Council of Europe. Therefore, the Forum strengthens and complements the normative efforts of the Organisation to legally regulate the right to a healthy environment.

The 47 member states of the Council of Europe assume the presidency of the main decision body, the Committee of Ministers on a rotational basis. As the procedures and working methods of the Committee of Ministers (CM) specifies "The Chair of the CM is held for a sixmonth term in turn by the representatives of the members in English alphabetical order. The Chair passes to a new Chair mid-May and mid-November, at a date fixed by the CM based on a joint proposal by the incoming and outgoing Chairs" (IGUIDE 2021, p. 2).

Georgia assumed the Presidency between November 2019 and May 2020 and set as its Chairmanship priority the interrelationship between human rights and environmental protection. The programme of the Georgian Chairmanship recalled that the European Convention on Human Rights (ECHR) does not mention the environment and it is not specifically designed to provide general protection of the environment as such. In their view, the legal protection from environmental harm is firmly tied to fundamental rights such as the right to life, the right to respect for private life and family life and the right to respect for one's home. The Georgian Presidency also aimed to strengthen environmental protection work in the Council of Europe through the existing programmes and treaties to secure better human rights protection standards in member states. In this spirit, the Georgian Presidency held an International High-Level Conference on Environmental Protection and Human Rights on 27 February 2020 in Strasbourg. This event supported the organisation by the European Court of Human Rights of an International Conference on Human Rights and Environmental Protection "Human Rights for the Planet" held in Strasbourg on 9 April 2020 at the European Court of Human Rights (PRIORITIES, GEORGIAN PRESIDENCY 2019). 
Rik DAEMS, the president of the Parliamentary Assembly also called for the upgrading of the current legal instruments, with the ultimate aim of drafting an additional Protocol to the European Convention on Human Rights concerning the right to a healthy environment. In this perspective, he presented a three-step plan: the drafting of a recommendation by the Committee of Ministers to the member States on human rights and the environment; a possible convention on this issue setting out some standards; as well as, in the medium term, the drafting of an addition Protocol to the Convention on Human Rights (SPEECH, RIK DAEMS 2020).

The joint declaration adopted at the end of the Chairmanship on 15 May 2020 acknowledges the worrying trend in respect of the climate and the environment, underlines the Council of Europe's commitment to environmental protection by referring its previous standard setting activity. The declaration proposed to launch a Council of Europe Strategy on the Environment and Human Rights with the aim of supporting member States in meeting their obligations in the field, including in respect of the United Nations Convention on Climate Change. The Declaration finally calls on the Committee of Ministers to elaborate a draft nonbinding instrument on human rights and the environment for the possible adoption by the Committee of Ministers at the latest by the end of next year (JOINT DECLARATION 2020).

The Hungarian Presidency scheduled between May and November 2021 also intends to promote the implementation of the Council of Europe's existing instruments in the field of protecting the environment, thus a special emphasis will be placed on the European Landscape Convention and the Bern Convention. International cooperation and mutual assistance to ensure the fundamental right to a healthy environment is also an important part of the Hungarian Chairmanship efforts (KORMÁNYHATÁROZAT 1616/2020).

\section{Conclusions}

A considerable period has passed since international organisations appeared on the world scene besides the governments, as traditional players. Despite the creation of international organisations, the states remained the main actors of international relations given the simple fact that the new organisations functioned as intergovernmental structures. CAPORASO asked the question right after the collapse of the bipolar world in 1992, "Why has the concept of multilateralism not played a more prominent role in theories of international relations?". The answer at that time was the lack of good examples or experience, or alternatively, the rise of bilateralism in the period of the Cold War. However, economists were already arguing already at that time that interdependence was on the increase, meaning that questions such as energy, 
pollution, air traffic, trade and investment could not be dealt with effectively within the national arena (CAPORASO 1992).

Due to these, mainly economic-related phenomena the perception about multilateralism has slowly changed as the influence and role of new players, the non-governmental or non-state actors has increased.

At present, the impact of civil society and non-governmental organisations is undoubtedly high on the activity of intergovernmental organisations. Besides, the governments are obliged to face more and more transnational challenges, the effective management of which go beyond the national competence and require cross-border coordination, indeed global cooperation. The environment is precisely that kind of transnational phenomenon and the fact that only international partnership could bring concrete results is not a recent recognition.

Gro Harlem Brundtland, the Chair of the UN World Commission on Environment and Development wrote in her report already in 1987 that "The traditional forms of national sovereignty are increasingly challenged by the realities of ecological and economic interdependence. Nowhere is this truer than in shared ecosystems and in 'the global commons' - those parts of the planet that fall outside national jurisdictions. Here, sustainable development can be secured only through international cooperation and agreed regimes for surveillance, development, and management in the common interest" (BRUNDTLAND REPORT 1987, p. 179).

After examining the ongoing developments in the Council of Europe related to the environmental protection and its connection to fundamental human rights, it can be concluded that the greatest added value of the Council of Europe is the possible elaboration of a new regulatory scheme. The case-law of the European Court of Human Rights already tackles to some extent the environment-related aspects, but the Organisation also deliberately aims to further and strengthen its norms through guidelines, recommendations, or new legally binding instruments.

In the light of the findings of the present paper, it is fair to say that it is not necessarily the international organisations but rather international cooperation which has the potential to save the environment. However, the international organisations have the means at their disposal to boost the level of interest at all levels of the society so that the public may seriously consider the impact of destruction of the environment. If the awareness-raising campaign is combined with legally enforceable targets, the international organisations, which include the Council of Europe, will have fulfilled their mission. 


\section{References}

AGOSTINHO, C.D. 2020: Et autres contre le Portugal et 32 autres États introduite le 7

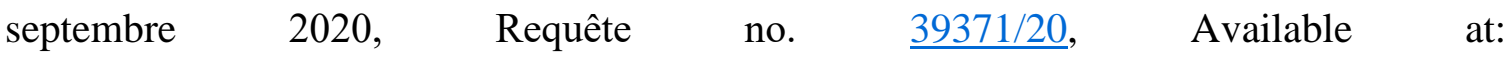
https://hudoc.echr.coe.int/eng\#\{\%22itemid\%22:[\%22001-206535\%22]\}, retrieved on 30 May 2021.

ALLISON, G. 2000: The Impact of Globalization on National and International Security, In: DONAHUE, J - NYE, J. (eds.): Governance in a Globalizing World, Brookings Institution Press, Washington D.C.

A LOOK INSIDE. 2016: A Look Inside, the World Forum for Democracy. Available at: https://rm.coe.int/CoERMPublicCommonSearchServices/DisplayDCTMContent?docume ntId=0900001680693fe5 Retrieved on 5 March 2021.

ANNUAL REPORT OF THE EUROPEAN COURT OF HUMAN RIGHTS. 2020: https://www.echr.coe.int/Documents/Annual_report_2020_ENG.pdf Retrieved on 30 May 2021, pp.17-18.

BRUNDTLAND REPORT. 1987: Report of the World Commission on Environment and Development, Our Common Future. Annex to document A/42/427, Available at: https://www.are.admin.ch/are/en/home/sustainable-development/internationalcooperation/2030agenda/un-_-milestones-in-sustainable-development/1987--brundtlandreport.html Retrieved on 5 March 2021.

CAPORASO, J. A. 1992: International Relations Theory and Multilateralism: the search for foundations. International Organization, Vol. 46, No. 3. pp. 599-632.

CM RESOLUTION. (87) 2: On Setting up a co-operation group for the prevention of, protection against, and organisation of relief in major natural and technological disasters, 20 March 1987, Available at:

https://rm.coe.int/CoERMPublicCommonSearchServices/DisplayDCTMContent?docume $\underline{\text { ntId }=09000016804 d 35 b 1}$ Retrieved on 5 March 2021.

COE ENVIRONMENT PROTECTION. 2021: Steering Committee on Human Rights for the Drafting Group on Environment (CDDH-ENV) on environmental Protection and Human Rights, CDDH-ENV(2021)04 Available at: https://rm.coe.int/0900001680a242c1\#_ftnref121 Retrieved on 30 May 2021. 
COE CONVENTION ETS 104. 1979: Convention on the Conservation of European Wildlife and Natural Habitats, European Treaty Series No. 104. Bern, 19. 19. 1979, Available at: https://www.coe.int/en/web/conventions/full-list/-/conventions/rms/0900001680078aff Retrieved on 6 March 2021.

COE CONVENTION ETS 150. 1993: Convention on Civil Liability for Damage Resulting from Activities Dangerous to the Environment, Lugano, 21.06.1993. Available at: https://www.coe.int/en/web/conventions/full-list/-/conventions/rms/090000168007c079 Retrieved on 6 March 2021.

COE CONVENTION ETS 172. 1998: Convention on the Protection of Environment through Criminal Law, Strasbourg, 04. 11. 1998 Available at: https://www.coe.int/en/web/conventions/full-list/-/conventions/rms/090000168007f3f4 Retrieved on 6 March 2021.

COE CONVENTION ETS 176. 2000: European Landscape Convention. Florence, 20. 10. 2000.

Available at: $\quad$ https://www.coe.int/en/web/conventions/full-list//conventions/rms/0900001680080621 Retrieved on 6 March 2021.

COE WEBSITE: Protecting the environment using human rights law, Available at: https://www.coe.int/en/web/portal/human-rights-environment Retrieved on 30 May 2021. COUNCIL DIRECTIVE (82/501/EEC) 1982: European Economic Community, Available at: https://eur-lex.europa.eu/legal-content/EN/TXT/?uri=CELEX\%3A31982L0501 Retrieved on 5 March 2021.

COUNCIL DIRECTIVE (96/82/EC) 1996: European Economic Community Available at: https://eur-lex.europa.eu/legal-content/en/ALL/?uri=CELEX\%3A31996L0082 Retrieved on 5 March 2021.

DIRECTIVE (2012/18/EU). 2012: European Economic Community, https://eur- Available at: lex.europa.eu/legal-content/EN/TXT/?uri=CELEX\%3A32012L0018 Retrieved on 5 March 2021.

DU PISANI, J. A. 2006: Sustainable development - historical roots of the concept. Environmental Sciences Vol. 3. pp. 83-96. https://doi.org/10.1080/15693430600688831

ESKENAZI, B. - WARNER, M. - BRAMBILLA, P. - SIGNORINI, S. - AMES, J. 2018: The Seveso accident: A look at 40 years of health research and beyond, Environment International 121. pp. 71-84.

EUROPEAN COMMISSION, ENVIRONMENT. 2021: Major accident hazards, Available at: https://ec.europa.eu/environment/seveso/ Retrieved on 31 May 2021. 
EXPLANATORY REPORT. 1998: Explanatory Report to the Convention on the Protection of Environment through Criminal Law, ETS 172. Strasbourg, 4. 11. 1998, Available at: https://rm.coe.int/CoERMPublicCommonSearchServices/DisplayDCTMContent?docume ntId=09000016800cce43 Retrieved on 6 March 2021.

FACING RISKS TOGETHER. 2012: 25 years of cooperation (1987-2010), Publication of the EUR-OPA Agreement Available at: https://www.coe.int/t/dg4/majorhazards/ressources/pub/FacingRisksTogether_25years_p ublication.pdf Retrieved on 6 March 2021.

FACT SHEETS ON THE EUROPEAN UNION. 2021: Environment policy: general principles and basic framework, Available https://www.europarl.europa.eu/factsheets/en/sheet/71/environment-policy-generalprinciples-and-basic-framework Retrieved on 31 May 2021.

GAZDAG F. - KOVÁCS P. 1999: Az Európa Tanács 1949-1999, Stratégiai Védelmi Kutatóintézet.

GRAY, M. A. 1990: The United Nations Environment Programme: An Assessment. Lewis\&Clark Law School. 20 (2): pp.43-49.

HIGGINS, P. - SHORT, D. - SOUTH, N. 2013: Protecting the planet: a proposal for a law of ecocide. Crime Law Soc Change. Vol 59, p. 257.

IGUIDE 2021: Procedures and working methods of the Committee of Ministers. Available at: https://search.coe.int/cm/Pages/result_details.aspx?ObjectID=090000168058d922\#_ftnre f2 Retrieved on 7 March 2021.

JOINT DECLARATION 2020: Joint declaration on human rights and the environment by the outgoing and incoming Presidencies of the Committee of Ministers. Available at: https://search.coe.int/cm/Pages/result_details.aspx?ObjectID=09000016809e59f9 Retrieved on 7 March 2021.

KORMÁNYHATÁROZAT 1616/2020. (X. 1.) az Európa Tanács Miniszteri Bizottságának 2021. május-november közötti magyar elnökségét előkészítő feladatokról, Magyar Közlöny $2020 . \quad 216 . \quad$ sz. Available at: file://C:/Users/AFerenci/Downloads/MK_20_216\%20(3).pdf Retrieved on 7 March 2021. MANDATE OF THE SECRETARY GENERAL'S SPECIAL REPRESENTATIVE ON MIGRATION AND REFUGEES 2020: Available at: https://rm.coe.int/mandate-of-the-

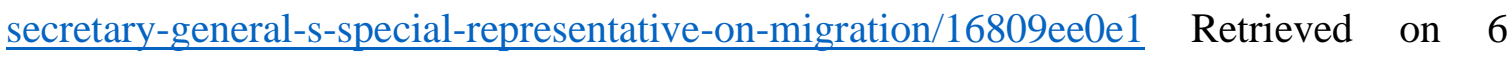
March 2021. 
MANUAL ON HUMAN RIGHTS AND THE ENVIRONMENT 2006, 2012: Manual on Human Rights and the Environment. Council of Europe Publishing, First edition 2006, second edition 2012. Available at: https://rm.coe.int/09000016806962d1 Retrieved on 30 May 2021.

MEADOWS D. H. - MEADOWS, D. L. - RANDERS, J. - BEHRENS III. W.W. 1972: Limits to Growth, A report for the Club of Rome's Project on the Predicament of Mankind. A Potomac Associates Book.

PACE RECOMMENDATION 1885. 2009: Drafting an additional protocol to the European Convention on Human Rights concerning the right to a healthy environment, Available at: https://pace.coe.int/pdf/2ed504fcbd64122567978650d32a664f2c63bbde3326667a8259ffe 25682ae848428feba12/recommendation\%201885.pdf Retrieved on 6 March 2021.

PACE RESOLUTION 1988. 2014: Recent developments in Ukraine: threats to the functioning of democratic institutions, Available at: https://pace.coe.int/pdf/8a104fdc5ab9d55bdee353e6d4b3bfb2bc4ebea93326667a8259ffe 25682ae848428feba12/resolution\%201988.pdf Retrieved on 3 March 2021.

PACE RESOLUTION 1633. 2008: The consequences of the war between Georgia and Russia, Available at: https://pace.coe.int/pdf/339a5f48957ffafc23aff0ad3eab714eb27040bd3326667a8259ffe2 5682ae848428feba12/resolution\%201633.pdf Retrieved on 3 March 2021

PRIORITIES, GEORGIAN PRESIDENCY. 2019: Priorities of the Georgian Presidency of the Committee of Ministers of the Council of Europe (27 November 2019 - May 2020), Available at:

https://search.coe.int/cm/pages/result_details.aspx?ObjectId=090000168098e8a4,

Retrieved on 7 March 2021.

RIO DECLARATION ON ENVIRONMENT AND DEVELOPMENT. 1992: A/CONF.151/26/Rev.1 (Vol. 1), Available at: https://undocs.org/en/A/CONF.151/26/Rev.1(vol.I) Retrieved on 6 March 2021.

PARIS AGREEMENT, UNITED NATIONS. 2015: Available at: https://unfccc.int/sites/default/files/english_paris_agreement.pdf Retrieved on 31 May 2021.

PROGRAMME AND BUDGET 2020-2021. 2019: Terms of Reference of Intergovernmental Structures, Steering Committee for Human Rights, 2019. Available at: https://search.coe.int/cm/Pages/result_details.aspx?ObjectID=090000168096a7de\#_Toc2 4124101 Retrieved on 30 May 2021. 
SPEECH BY RIK DAEMS. 2020: High-level conference on human rights and the protection of the environment, 27 February 2020. Available at: https://rm.coe.int/president-s-daemsspeech-conference-environment-and-hr-edited-12-03-20/16809ce391 Retrieved on 30 May 2021.

STATUTE OF THE COUNCIL OF EUROPE. 1949: London, 5 May 1949, Available at: https://www.coe.int/en/web/conventions/full-list/-/conventions/treaty/001 Retrieved on 30 May 2021.

STEERING COMMITTEE FOR HUMAN RIGHTS. 2020: Report of the $92^{\text {nd }}$ meeting, 20 December 2020, Available at: https://rm.coe.int/cddh-2019-r92-en/168099535f, Retrieved on 30 May 2021.

TERMS OF REFERENCE. 2020: Terms of reference for the CDDH Drafting Group on Human Rights and Environment (CDDH-ENV), Appendix VI of the $93^{\text {rd }} \mathrm{CDDH}$ plenary meeting, 14-16 December 2020, Available at: https://rm.coe.int/steering-committee-for-humanrights-cddh-report-93rd-meeting-strasbour/1680a134a9 Retrieved on 30 May 2021.

TREATY ON THE FUNCTIONING OF THE EUROPEAN UNION. 2012: Official Journal of the European Union, 6 October 2012. Available at: https://eur-lex.europa.eu/legalcontent/EN/TXT/PDF/?uri=CELEX:12012E/TXT\&from=EN Retrieved on 30 May 2021.

UNGA RESOLUTION 2997. 1972. Resolution on the Institutional and financial arrangements for international environmental cooperation Available at: https://undocs.org/en/A/RES/2997(XXVII) Retrieved on 6 March 2021.

UNGA RESOLUTION 38/161. 1983: Process of preparation of the Environmental Perspective to the Year 2000 and Beyond, 1983. Available at: http://www.undocuments.net/a38r161.htm Retrieved on 5 March 2021.

UNGA RESOLUTION 55/2. 2000: Millenium Declaration of the United Nations, 2000. Available at: https://undocs.org/A/RES/55/2 Retrieved on 6 March 2021.

UNITED NATIONS REPORT.1972: Report of the United Nations Conference on the Human Environment, Stockholm, 5-6 June 1972, chapter 6, section 5, Available at: https://www.un.org/ga/search/view_doc.asp?symbol=A/CONF.48/14/REV.1 Retrieved on 6 March 2021.

WHITE, R. - HECKENBERG, D. 2014: Green Criminology: An Introduction to the Study of Environmental Harm, Routledge, pp. 45-59.

WORLD FORUM FOR DEMOCRACY. 2018: Gender Equality: Whose Battle? Available at: https://rm.coe.int/world-forum-for-democracy-2018-conclusions-andrecommendations/168091f52d Retrieved on 6 March 2021. 
WORLD FORUM FOR DEMOCRACY. 2020: Concept Note, $9^{\text {th }}$ Edition. Available at: https://rm.coe.int/world-forum-for-democracy-2020-can-democracy-save-theenvironment-stra/16809e67a0 Retrieved on 6 March 2021. 


\section{Chapter IV}

\section{Analysing sustainability issues in regional/national economic dimension}




\title{
The promise of sustainability and the pandemic? How Hungarian fashion production companies could gain better position in the global supply chain due to relocation tendencies
}

\author{
Emese DOBOS-NAGY ${ }^{71}$
}

\begin{abstract}
East and Central European countries have been operating as invisible 'tailor shops' for Western fashion brands for decades. Fashion brands lately are moving back from Asia and this process can lead to a stronger European fashion industry. The COVID-19 pandemic could act as a catalyst to an already ongoing relocation tendency in production as the need for shorter, more resilient supply chains and the reform of existing production practices has been growing and serves sustainability. The aim of my paper is to examine the social aspect of the fashion industry and opportunities for Hungarian fashion production companies in terms of economic sustainability and competitiveness. My goal is to focus on examining the possible solutions of the tension between economic and social sustainability due to relocation tendencies as capacity (e.g. limits of labor, aging employers (employees?) and lack of technology development) versus growing orders and that existing assembly activity, contract work and that most workers are trained-on-the job or had vocational training. On the one hand, it is a disadvantage as it means low value-added process while on the other hand, fashion industry is a significant employer in rural areas for people with disabilities as well. The methodology of this research is qualitative (literature review and interviews).
\end{abstract}

Keywords: re-location, global supply chain, Hungary, fashion industry, sustainability

\section{Introduction}

Sustainability has become a recent buzzword in the fashion industry as it has in other industries, but we have to differentiate between economic, social, and environmental sustainability. The three conceptual pillars of the paradigm of sustainability were first suggested by KAHN in 1995. According to his theory, the principles of economic sustainability are growth, development, knowledge and awareness, that market allocation of resources are limited and that there is a 'trickle-down' effect, suggesting that growth helps the poor. Social sustainability is usually considered as poverty alleviation and equity, empowerment, accessibility, participation, sharing, cultural identity and institutional stability. Furthermore, environmental sustainability refers to eco-system integrity, carrying capacity and biodiversity where natural resources are seen and handled as a source of economic inputs and a sink for waste (KAHN 1995).

The social aspect of sustainability has been neglected and is also one of the most difficult to define. The failure of development and economic growth sparked a growing interest in social sustainability, but it has been termed as a 'concept in chaos' which compromises its importance and utility (VALLANCE et al. 2011). The authors suggest that social sustainability has three

\footnotetext{
${ }^{71}$ Corvinus University of Budapest, Doctoral School of International Relations and Political Science, PhD student, emese.dobos-nagy@stud.uni-corvinus.hu
} 
components: the first, 'development' sustainability, is concerned with meeting basic needs, inter- and intra-generational equity; second, 'bridge sustainability' focuses on changing behaviour so as to achieve bio-physical environmental goals; third, 'maintenance sustainability' refers to social acceptance or what can be sustained in social terms.

MCGUINN et al. (2020) also emphasize that there is a fuzzy concept around social sustainability with no universal definition and adds core themes such as: human well-being and equity, access to basic needs, fair distribution of income, good working conditions and decent wages, equality of rights, inter-and intragenerational justice, access to social and health services and to education, social cohesion and inclusion, empowerment, and participation in policymaking (MCGUINN et al. 2020).

According to the voluntary sustainability initiative UN Global Compact, while it is the primary duty of governments to protect, respect, fulfil and progressively realize human rights, businesses can, and should, do their part. The Global Compact defines social sustainability from the firm's point of view, as doing business in ways that benefits society and protects people (UN Global Compact). The cornerstone of the social dimension of corporate sustainability is human rights. The UN Global Compact expects businesses to undertake due diligence to avoid violating human rights and to address any adverse impacts on human rights that may be related to their activities and additional steps, such as creating decent jobs and more inclusive value chains.

Kahn's concept says that the three pillars of sustainability have to be coordinated in a comprehensive manner, so that integration and interlinking can arrest the negative synergies. However, as I suggest, there is a fundamental conflict of interest - or at least a tension - among several factors. Within Hungarian fashion companies - regarding the features of the industry's supply chain and the characteristics of local companies - I identified several correlations worth studying. One of them is the minimum wage raise, which on the one hand means a higher salary for employees, however, on the other hand, for employers it means losing competitiveness. Furthermore, significant contract work and lack of capital; that means a low value-added activity; results in a trap for Hungarian fashion companies in subcontracting and make it challenging for moving towards higher value-added levels. The lack of capital also makes automatization more difficult, and adversely affects the development of plants and investing into new technologies and developing new solutions for companies that would increase their attractiveness among clients and increase productivity.

According to Jeremy Rifkin, technology will always be cheaper than the cheapest labor. His vision is jobless factories in the future as information technology eliminates tens of millions 
of jobs in the manufacturing industry (RIFKIN 1995). If technology leads to a reduced workforce, it will not serve social sustainability and inclusive employment. As minimum wages increase companies lose their competitive advantage, and because of the seasonal rhythm of fashion (I will elaborate on this later) it makes it difficult for companies to manage their decreasing margins. The growing lack of labor and problem of aging employees have long posed challenges to the Hungarian fashion industry, as it grapples with the potential benefits of shorter supply chains and relocation tendencies.

The fashion industry term comprises several aspects such as design, production and retail, and includes many segments such as textiles, garments, shoes, leather and fur and even textile cleaning, from the production of raw materials through the care, design and making of the garments to retail and even communication. The textile industry primarily produces raw materials for the garment industry, such as the production of the underwear and outerwear. I use fashion industry to refer to garment production intended for export (contract work for foreign brands) as it is the most relevant segment in terms of the discussion of Hungarian fashion production, representing the biggest value in exports and the biggest employer within different segments.

The textile industry is considered to be a significantly higher polluter than garment manufacturing. As textile production is mainly based in Asia and Hungarian fashion companies rely on the already produced raw materials from the textile segment, I will focus mainly on the social aspects of sustainability.

This paper focuses on the host country's manufacturing background and the position of Hungary's fashion production companies due to the shorter supply chains boosted by the COVID-19 pandemic. Two questions are at the center of this research. First, are we moving closer to shorter supply chains? There is a growing literature in recent years in terms of (theoretical) examining the possible positive effects of shorter supply chains (both environmentally and economically). Second, in view of tensions between economic and social sustainability, what effect will shorter supply chains have on the Hungarian fashion industry and production sector (nearshoring, backshoring and onshoring)?

\section{The neglected social sustainability in the fashion industry}

The fashion industry is repeatedly referred to as 'the second most polluting industry of the world' (FRIEDMAN 2018). The most discussed and known sustainability issues of fashion are carbon emission, water consumption and pollution, environmental and microplastic pollution, and waste generation (MCFALL - JOHNSEN 2020). There is also a practice among 
fashion brands of burning unsold collections at the end of the season, mainly with the aim of image-protection, causing serious environmental concerns (NAPIER - SANGUINETI 2018).

Although sustainability concerns among the fashion industry have risen during the past few years, there is still a lack of reliable sources and data on the ecological footprint of the industry. Due to its impossible-to-trace supply chain, it is hard to put a number on it (FRIEDMAN 2018). The current overproduction and overconsumption of the fashion industry is far from offering the economic sustainability in which supply satisfies the present consumption level without compromising future needs. With outsourced production, fashion companies can also turn a blind eye to environmental issues, human and labor rights violation during production.

The current discussion about the sustainability of fashion is more centered around the environmental aspect - the social pillar is rather neglected. This omission was also underscored by The Fashion Pact (signed by 49 major fashion brands at the G7 Summit in 2019), one of the first, largely celebrated sustainability joint commitments to key environmental goals among leading actors. Labor rights fashion NGOs (Fashion Revolution, Fair Wear) have criticized the initiative for omitting the social aspect of the fashion industry.

The world press has also covered and followed worker rights exploitation (e.g. sweatshop cases, The collapse of Rana Plaza in 2013), infringement of labor rights and working conditions, but the leading discourse and commitment of fashion brands are centered around environmental issues and the use of 'greener', recycled and organic materials.

While other industrial sectors (like automobiles and electronics) build strategic partnerships and have their own factories and subsidiaries, the admitted practice in the fashion industry is working together with independent suppliers who are producing for several brands. (ANTALÓCZY - SASS 1998). That is also in line with the absence of due diligence practice and the issues of direct responsibility among fashion brands towards aspects of social sustainability. Furthermore, commitments towards granting living wages and proper working conditions are even outsourced to third party auditor companies in the fashion industry. The system has proved to be a hideaway for fashion brands and does not serve the interests of fashion workers (CLEAN CLOTHES CAMPAIGN 2019). This was also confirmed by a 2018 research from the Sheffield Political Economy Research Institute. Their main conclusion was that even when fashion brands are members of initiatives established to grant living wages and the development of fair working conditions, the opaque system allows them to relinquish direct responsibility (EDWARDS et al. 2019). 
Furthermore, although discussion around the (un)sustainability of the fashion industry is mainly centered around fast fashion, other market segments (that I will discuss later) of the fashion industry cannot be considered 'innocent' either. The question is still open and unanswered regarding primarily voluntary and mainly image-making sustainability commitments, the ever-growing greenwashing of the fashion brands when it reaches a critical mass of the customers and turns to actual financial pressure under the guise of being more sustainable.

Another question is also being raised in the center of debate of fashion's sustainability, namely: the responsibility of fashion companies. As fashion is intensively globalized and most of the activities are outsourced, furthermore the supply chain is notoriously impenetrable, making monitoring and traceability challenging. There is an ongoing process within the European Union towards the regulation of supply chains: the German government has published a draft supply chain law that aims to hold companies accountable for human rights breaches. It is considered to be Europe's strongest legislation against worker exploitation (WATTS 2021).

\section{How COVID-19 disrupted the supply chain of the fashion industry}

The year 2020 also heightened the awareness of many challenges the fashion industry is facing, including supplier relationships, greenhouse gas emissions (GHGs), employment structure, overproduction and waste. The COVID-19 pandemic most visibly disrupted the global supply chains of the fashion industry: as China is the biggest exporter of textiles (WORLD TRADE ORGANIZATION 2020), it raised the concerns in terms of dependency. When the pandemic broke out in China, the flow of raw materials to fashion producing companies in various countries was cut off as the pandemic spread - and variably affected the different continents and countries. The fashion industry (including production, retail and consumption as well) faced various disruptions when the pandemic hit Western (European) consumer markets, with store closures and cancellation of fashion brand orders from mainly Southeast-Asian and East-Central European companies, or companies stuck with unsold collections (TEODORO-RODRIGUEZ 2020).

Consequently, COVID-19 not only meant closed stores for fashion businesses but a humanitarian crisis at the end of the supply chain. Many brands cancelled orders when the first pandemic 'hit' with lockdowns, refusing to pay for billions of dollars of goods that had already been manufactured and shipped (ANNER - NOVA 2020) before the coronavirus outbreak. The result was devastating for the countries and millions of workers throughout the region of Southeast Asia. After a year, fashion companies slashed prices to stay competitive and orders 
for the current season were down by $30 \%$ compared to the previous year; manufacturers even accepted orders below cost (DEELEY 2021). From the perspective of economic and social sustainability, the pandemic is having a devastating effect on the dependent end of the supply chain.

The coronavirus pandemic and the following crisis turned attention to the importance of shorter supply chains and the need to reform existing production practices. Despite some progress being made by the global fashion industry in terms of wanting to escape from the codependent relationship with China, the country remains the powerhouse of manufacturing infrastructure and a primary source of raw materials and other products, like trims and zippers (HALL 2020). Because of its labor-intensive nature as well as its geographical footprint, the garment value chain is one of the most exposed to supply chain shocks. Still, the interconnectedness and the economic case for making large-scale changes in the physical location of supply chains also has limits, such as making long-term investments or accepting a higher cost of goods (LUND - KRISHNAN 2020). As textile and garment companies operate in a competitive and highly globalized market, this puts pressure on prices and margins, leaving companies little buffers for such crises (EURATEX 2020).

\section{Delocation, then relocation: Problems with the supply chain of fashion}

\subsection{The theories of delocation and the characteristics of fashion}

Fashion, especially the garment industry, is the most globalized industry of all (BONACICH - APPELBAUM 2000). Several factors and motives are shaping the production background of the fashion industry: international trade relations, regulations and agreements, institutional frameworks and conventions, the structure and business model of the certain fashion brands, (new) technology and human resources. Lately, social media and visibility, customer perceptions and expectations - for example the effect of 'Made in' - and transparency and sustainability concerns are also among the shaping factors of the fashion industry.

The concepts of global commodity chains and value chains examine the world economy in light of globalization's geographical inequalities. A common point they consider is that inequalities are caused by the way in which construction is organized. Even if we talk about production-driven or consumer-driven supply chains (GEREFFI 2001), internal power asymmetry provides different opportunities for position and profit-making (MOLNÁR 2017).

By PORTER's 'location paradox' (PORTER 1990), fashion brands - independently from the closeness of their market destination - outsourced production to independent suppliers and 
subcontractors, rather than own factories - where production is the cheapest. Working together with independent factories and low labor cost allowed them to flexibly move (towards) production and assured competitiveness. Fashion brands can react quickly to economic changes by creating their own locations that lead to profitability in the long-term, by terminating fully or partly owned production facilities, and by outsourcing and using short-term contracts.

According to comparative advantage, a feature of the delocation of the fashion brands' production is that it moves resources and capabilities that can be developed during a certain time, rather than natural resources. A worker with a lower wage (naturally compared to the original country) who can be 'trained-on-the job' for relatively easy-to-make assembly tasks, can enjoy an absolute advantage, and that country can export more effectively (due to the lack or scarcity of the local, internal market). The Heckscher-Ohlin model (OHLIN 1967) says that countries export products that use their abundant and cheap factors of production and import products that use the countries' scarce factors. Furthermore, the factor theory says that comparative advantages in international trade do not come from differences of productivity, but rather from the availability of certain production factors. On the production side of the fashion industry, formerly fashion brands generated profits primarily from low labor costs.

The textile and garment industry (especially the later as the needed technology/plant is relatively cheaper and easier to establish) with its high need of human labor are often a first step of industrialization in a developing country's economy (FUKUNISHI - YANAGATA 2014), while developed countries are moved towards upgrading, processes that require knowledge, higher value added and the opportunity for better profit (GEREFFI MEMEDOVIC 2003). Upgrading means stepping out from a dependent position which is made possible through taking strategic functions and building own supply chains (SCHMITZ 2006). In the fashion industry, we can distinguish CMT (cut-make-trim), OEM (Original Equipment Manufacturing - manufacturing with the addition of sourcing equipment and raw materials), ODM (Original Design Manufacturing - manufacturing with the addition of design) and OBM (Own Brand Manufacturing) as steps of development.

With a neoliberal world economy, peripheral countries (like China, Bangladesh and Vietnam) became popular for fashion brands to outsource production for cheap labor as well as for cost-effectiveness. Outsourcing has also targeted semi-periphery countries (Central and Eastern Europe, former soviet successor states and Balkan countries), and occurs within a country's border as well (e.g. Italy). This extensional inequality relation is described by Wallerstein's core-periphery model (WALLERSTEIN 1974). Extensionally, geographical inequality can be also described by the so-called pyramid model of the fashion industry: at the 
top of the pyramid are the luxury brands and their small quantity collections ('officially') made by expert designers in Western-Europe (Italy and France especially have a long-standing heritage in the luxury sector); placed in the middle of the pyramid is the production of the readyto-wear segment (with bigger orders) made in Spain and Turkey; and at the base of the pyramid are the former socialist countries and the mass production of brands made in China and Southeast-Asian countries (THOMAS 2008). From the 1990s, the basis of the collaboration between Western and Eastern European countries' fashion industry was the so-called outward processing trade (OPT) practice: contractors transported semi-processed products, like fabrics, cuttings or semi-finished products to low wage subcontractors in Eastern Europe for assembly and intermediate work processes (HANZL - HAVLIK 2003). As a result, periphery countries acted as 'sewing workshops' for Western fashion brands, a practice that has also remained after the regime change and accession to the European Union as well. The region is attractive for Western companies because of its geographical and cultural proximity, the existing production capacities, qualified workforce and low-level respect and inadequate adherence to national labor rights regulation (TERRE DES FEMMES 2002). In parallel with delocation tendencies, European fashion production also became a 'declining industry' with the Hungarian fashion industry becoming deeply integrated into global supply chains through the high rate of export and contract work. Eastern-Central Europe is designated as semi-periphery in the world economy because of its intermediate and dependent position. According to ARRIGHI and DRANGEL, revenue from the core countries is able to block the periphery's interests and they provide low income for them to stay in that position (MOLNÁR 2017). This theory holds validity in terms of the history of the region's fashion production, as to this day companies do not earn enough from contract work to move towards significantly higher value-added processes or releasing their own products.

Subcontracting, along with delocation is an intensifying feature of the fashion industry. The delocation - the remove from the local, native location and the outsourcing of certain processes - of the garment industry started in the 1950s with Japanese, Western European and American brands delocalizing towards Southeastern Asia, especially China (and EasternEurope) and intensified with the financialization of the world economy (MONTERO 2011). The growing 'internationalization' of the fashion companies and the stepping into new markets and reaching out to new customer segments and strengthening middle classes provided the opportunity to widen their markets and reshaped the structure of fashion production, making it geographically fragmented. The fragmented production and the delocation of manufacturing (and the ceasing of own production) gave the opportunity for fashion companies to reduce their 
costs with the delocation of labour-intensive processes, but had a degrading effect on local light industry (AMIGHINI - RABELLOTTI 2010).

With intensified globalization, we have to separate the 'headquarter' country of the brand and the actual country of origin (COO). Delocation can look as if low value-added, labor intensive processes (CMT, assembly activities) are outsourced while high value-added activities (design and product development) are retained in the original country (AMIGHINIRABELLOTTI 2010).

It is more sensible to see brand image (especially luxury brands) as being strongly associated with the $\mathrm{COO}$, which indicates quality and a proof for the conditions in which the product is made and how it was made. Sustainability and ethical fashion have become ever more important determinants in customers' decisions (FUTUREBRAND 2014).

According to ANTALÓCZY and SASS (1998), Hungarian fashion companies work for 6-8 brands at the same time, often through intermediates. German and Austrian clients are willing to build longer partnerships, but Italian and French companies pay lower fees, change their suppliers often and make contracts for 4-5 months at a time. From the perspective of the host country, contract work is usually evaluated negatively as the subcontracting companies are heavily dependent and vulnerable.

During CMT and OEM processes in the garment manufacturing even if there is no 'official' knowledge transfer and no need for special know-how (just a need for on-the-job training) for assembly activities, we will see from the example of Hungarian fashion companies that producing garments for 'Western demand' helped them to acquire and learn the proper means of making quality garments even in the absence of contract work.

\section{2. Triggers for relocation}

Decades ago, several European and American fashion brands rushed to reallocate their production to Asia with the aim of reducing labor costs. But the differences have become smaller as wages in peripheral countries have also increased. Fashion brands can benefit from proximity of production to their markets as well (BOF - MCKINSEY\&COMPANY 2019). The fashion industry has reached a crossroads where speed beats marginal cost advantages and sustainability concerns are getting stronger. Traditional fashion supply chains are facing challenges due to convergent labor costs. Transportation is also significant: sea transport is the most common, but this takes time: around 30 days are required for a parcel to reach WesternEuropean markets from Asia, and air transport is considered to be too expensive (ANDERSSON et al. 2018). The 'slowness' of sea transport will not be able to serve the current 
need for speed in the fashion industry and will thus need to be balanced with air transport. Former advantages of delocation are also derogated by geopolitical tension, which brings insecurity to trade agreements and fluctuating exchange rates. Relocation, as the action of moving to a new place primary focuses on fashion, moving away from Asian production takes place in nearshoring. As the practice of transferring a business operation to a nearby country, especially in preference to a more distant one, and backshoring or onshoring as the repatriation of production to the home country.

With outsourcing and delocation the fashion brand does not have to invest into the needed plant and ongoing technological development, therefore it can easily move production to another place. One single fashion collection can contain around hundred 'looks' (a whole set of garments, like trousers, blouses, coats and additional accessories) and every single garment might require different technology and expertise. In the past, fashion brands presented two main collections (spring-summer and autumn-winter), then the industry added two additional collections (resort/cruise and pre-fall). With the growing pressure from fast fashion brands who present new garments on a weekly basis, the practice of 'upper' fashion brands have also changed, and we can witness the changing (growing) speed of fashion (several smaller collections per year) and a more 'on-demand' practice. This means a more rapid product cycle and shorter, more insecure relationship between fashion brands and suppliers. With the growing importance of speed in production and the fast-paced changes in fashion trends, the process has resulted in increasing domestic production that drives down costs and results in shorter lead times. Recent studies refer to this process as nearshoring (ANDERSSON et al. 2018).

Conventional organizational structures and forecast-driven supply chains were formerly declared to be inadequate to meet the challenges of volatile and turbulent demand which typify fashion markets today; there is a constant call for agile supply chains to manage this volatility (CHRISTOPHER et al. 2004). Even if there is a tendency for the rationalization of the supply chain (meaning fewer suppliers for fashion brands), relying on a smaller number of suppliers can increase the risk of supply chain disruption (MCMASTER et al. 2020).

Ordering and producing smaller quantities closer to the home country is also a tool for cost-effectiveness and can serve sustainability as well because relocation means reduced carbon emissions in transport and overproduction.

Even if we consider delocation (and outsourced production) as a continuously ongoing tendency, operational challenges and increasing costs affect the management of the global supply chain. This leads to the reconsideration and reorganization of the activities within the 
supply chain, such as relocation of production or switching to a local supplier (ROBINSON HSIEH 2016).

Developments in automatization and robotics have diminished the comparative advantages of low-cost countries (ROBINSON - HSIEH 2016). Furthermore, relocation tendencies are making supply chains more transparent and traceable, which supports sustainability. Nearshoring and onshoring can make even more economic sense as technology develops because automation will increase labor productivity, thus offsetting higher labor costs of near-and onshore production. But the garment industry is lagging behind other sectors in automation. One reason for this is that fashion companies rely on cheap labor; and the other is that sewing fabrics have proven difficult for robots to handle. Only in recent years have solutions for automation in sewing selected fabrics become market ready (ANDERSSON et al. 2018). The complexity of the garments and the wide range of fabrics within one collection make automation more difficult. On the other hand, challenges posed by automation are beneficial because this elevates the importance of human labor and employment.

Various literature (KINKEL - MALOCA 2009; KINKEL 2012) dealing with relocation tendencies and reshoring, mentions a correction-strategy undertaken by fashion companies for bad decisions made with regards to the location of production in which they have miscalculated the benefits, costs and risks of outsourcing and production (ROBINSON - HSIEH 2016). Costefficiency is not the only consideration of relocation: the recognition of the importance of local supply and production, changing customer needs, cost reduction and optimalization of the supply chain are also factors behind relocation tendencies. According to Robinson and Hsieh, certain fashion brands have started to reconsider the location of their production based on the customers' perception of value connected to the 'Made in' effect, which also affects their position on the market. Pressure from (social) media and nongovernmental organizations and scandals in connection with human and labor rights violations mainly in Southeast Asia can also shape fashion brands' decisions as part of an 'image saving', more 'reliable' working conditions and more regulated (but not necessarily enforced) labor rights.

ANDERSSON et al. (2018) identified nearshoring, automation and sustainability as the three main tools for establishing a demand-focused garment value chain, offering nearshoring to mass market brands as well, stating that this tendency will not happen without challenges. As we have seen, relocation tendencies have been welcomed and even introduced in higher parts of the fashion pyramid. Bringing production back closer to consumers by near- and onshoring offers the opportunity for reducing the lead time. According to their survey, however, fashion brands are more likely to take action by 2025. Garment production in Central 
and Eastern European is fragmented (SMEs dominate), with volatility in quality and labor productivity in some countries where companies carry own environmental and social compliance risks. One of the main challenges is the sourcing of raw materials - which are dominantly sourced from Asia. European fabric and yarn production focuses on premium products and luxury customers.

\section{Promise or devastation? The effect of the (ongoing) coronavirus pandemic}

\section{1. Characteristics of the Hungarian fashion industry}

The labor-intensive garment industry is a significant employer in rural areas of underprivileged women, ethnic minorities, migrants and people with disabilities (MOLNÁR 2017). The 6600 companies of the Hungarian textile and garment industry employs more than 30 thousand people, according to the Central Statistical Office. Companies on average employ around 10-25 people, mainly to produce foreign fashion brands for export. They are not only capable of producing big series (1500-2500 pieces in an order) and for high category fashion brands like Stella McCartney, Nina Ricci, Saint Laurent, Dolce \& Gabbana, Valentino and Carven, but are able to create haute couture garments with high craftmanship as well. The leather industry (foot, bags, belts) 'enjoys' the highest rate of export, followed by the textile industry. The export rate for the garment industry (undergarments like lingerie, bathing suits and outerwear like coats, trousers, dresses, etc.) is around 80\% (DOBOS-NAGY 2021b). Even though the Hungarian fashion industry is relatively smaller in size, compared to neighboring Romania (employs around 400 thousand people), Hungary stands 'in midfield' in CentralEastern-Europe's fashion industry.

I want to emphasize the fact that we cannot entirely rely on official statistics in terms of numbers of companies and employed. There are companies that operate under different TEÁOR (Classification of Economic Activities) categories in terms of activities that identifies them with garment production, and there are companies that operate as 'zugvarroda' (corner sewing shops): the term refers to fashion companies who work illegally without providing social security or granting minimum wages for the workers.

As I have written previously, Eastern-Central Europe is called the semi-periphery of the world economy in world literature - a reference to its intermediate and dependent position. According to ARRIGHI and DRANGEL, revenue from the core countries is able to block the periphery's interests and they provide low income for them to stay in that position (MOLNÁR 2017). This theory holds validity in terms of the region's fashion production, as to this day 
companies do not make enough profit from contract work to move towards significantly higher value-added processes or releasing their own products (this section has been stated earlier).

A joint survey carried out among Hungarian fashion companies in March 2020 by the Hungarian Society of Textile Technology and Science (TMTE) and the Association of Hungarian Light Industry (MKSZ) reported that three quarters of the companies are preparing for a more than $50 \%$ loss in their yearly production in 2020 , and $60 \%$ had to lay off half of their employees (TMTE - MKSZ 2020). This result is in parallel with the conclusion of the European prognosis and the results of The European Apparel and Textile Confederation (EURATEX) survey, which reported that companies expect a $50 \%$ drop in sales and production and $80 \%$ of them are already laying off workers. Finally, the confederation forecasted the shutdown of every fourth European fashion company (EURATEX 2020).

Hungarian companies were negatively affected as Italy and France faced serious pandemic-related lockdowns because of their heavy dependence on Western-European contract work. These two countries represent a significant number of clients and an important retail destination for Hungarian made fashion products. Fashion production companies which offered very low costs for clients were more likely to face a financially challenging situation amid the pandemic. A few months later (after a spring shock) companies reported increasing orders and the comeback of clients. Furthermore, the local fashion industry envisions reduced seasons and collections, smaller orders, and more sustainable consumption within the industry in a long term (DOBOS 2020).

In the following, I will highlight the main points and arguments of the unstructured extensive interviews worth considering in terms of labor and social sustainability, relocation tendencies and capital and automation.

\subsection{Relocation promises}

The Hungarian Fashion \& Design Agency (HFDA) was established as a subsidiary of the Hungarian Tourism Agency in 2018, with the aim of providing structured and efficient professional assistance to all players in the industry. The HFDA prognoses how the retreating role of the Far East in the region's fashion industry and relocation tendencies can help reduce fashion's carbon footprint and foster sustainability. From their point of view, relocation is significant within German companies. “The region's countries are a favorable production partner for Western-European brands because of the low labor cost and tax burden (compared to the home country) as they are willing to pay more for good quality and reliable solutions since they have been disappointed in Asian production" (DOBOS-NAGY 2021b). They also 
urge and consider collaboration, strategic partnership among the region's countries. They established a mentor program in August 2020 for fashion companies with the aim of developing their management, operational, sales and technology skills to improve their position in the region and in the international market. "As competition is very tense among the highest category fashion brands, everyone wants to work with the best producers who offer the best quality. The small Hungarian companies are in a great position as they are flexible and can work as an atelier, offering high handcraft skills and making complex products as well" (DOBOS-NAGY 2021b).

According to Anna HANNAUERNÉ SZABÓ, head of the Textile and Garments Section of the National Association of Entrepreneurs and Employers (VOSZ), several fashion companies are seeking work contracts now and would greatly benefit if the procurement of contracts for vestments were produced by Hungarian companies. The fashion companies suffered a $13 \%$ loss in production last year and the rate is even bigger within companies that apply contract work. From her experience, relocation is not happening now. 'We have seen positive displacement tendencies 2 years ago, around 2019. But one of the biggest clients of Hungarian fashion companies- German clients - are 'sitting on the floor' right now." Fashion companies which can produce overalls for medical use are in a good position at the moment. "The production of home and car industry textiles helps fashion companies; it improves their statistics in a wild way" (DOBOS-NAGY 2021c). She also emphasized a tendency within local companies of moving towards other segments, like specializing and working with functional textiles as garment production is decreasingly beneficial. She sees the role of intermediate agents (mentioned above) decreasing, as it makes the whole production process more expensive, but points to the fact that without distributors, working for several, significant big companies is nearly impossible.

Elegant Design Ltd. operates as an upgraded company since they act as intermediaries and subcontract assembly activity to 12 local and 20 Romanian factories, specializing in product development and logistics as well, working with 25 brands and welcoming new ones during the pandemic. I interviewed the director of the company, Ildikó MEDGYESSY. "We are getting enough (orders), but the prices are lower, by $10-20 \%$ or even by $30 \%$ and clients are paying later than the average." The director sees contract work as a chance for survival as most of the Hungarian companies do not have time and capital for developing own products (the financial return on own products is around 1 year, and contract work pays after 4-6 months). As one of the biggest fashion companies in Hungary (employing more than 100 people), her company finds itself in a very difficult situation with not enough orders for the season since one of its 
biggest clients, an Austrian company, just closed operations. According to her, the worst scenario is that the local industry will shrink and bigger companies (employing around 50 people, of which there are only a few) will disappear and small, atelier-type companies will work with anyone who can produce smaller quantities and is not in rivalry with Chinese 'vállfás áru’ (higher market category garments) (DOBOS-NAGY 2021a).

One of the biggest garment factories, the successor of 'Vörös Október Ruhagyár' (Red October Garment Factory) and former Berwin Ruhagyár Zrt. (Private Limited Company), now ARJ Ruhagyár Zrt. (Private Limited Company) in Vásárosnamény left its 530 workers 'in the lurch' in 2020. The company is a rare example of foreign brand ownership: the putative British owner, Edinburg Wollen Mills retail group neither fired nor paid the workers of its Hungarian suppliers. The workers at Vásárosnamény, who earned 120-130 thousand forints a month (that is less than the settled national minimum wage), had sewn male suits for mainly the Baumler, Paul Costelloe and Ted Baker brands. There are no other employment opportunities close to the Ukrainian border and with the closing of the company, livelihoods of entire families working at the factory has been threatened. The probable causes of the closure were reduced orders and bad management, while the COVID-19 pandemic was another body blow for the loss-making company (NAGY 2020).

The joint KÉZMÜ, ERFO and FÖKEFE nonprofit company is the biggest employer of workers with reduced work capacity and people with disabilities. On 140 manufacturing sites with 10 thousand employees, $83 \%$ are workers with reduced work capacity. The company has clients with whom they have been working for 5-10 years. Currently, 20\% of their partners are 'new' (started working with them during the past 1-2 years) and they are experiencing a 'dayto-day' growth in new clients. In their experience, those fashion brands who offer smaller series were not likely to outsource their production to the Far-East. They also confirm the increasing occurrence of fashion brands' relocation of production from Asia, according to their numbers from the past 3 years, and even brands offering bigger quantities want to find partners in the region. It has been their experience that it is primarily German, Austrian and Italian fashion brands that are relocating their production and offering confections, home textiles, bags and leather goods. "The process has also begun with the sourcing of raw materials. China offers overall favorable prices for the finished products, but these textiles are relatively expensive when compared to cheap production cost. Those (fashion brands) that want to run production closer to home, find better prices for textiles in the Near East" (DOBOS-NAGY 2021c). According to this joint nonprofit company, flexibility is one of the most important attributes for fashion brands who are suffering from shrinking markets and a challenging marketing 
landscape for which they cannot give a 'long-term prognosis'. To counter this challenge, they will need to adhere to very strict deadlines (DOBOS-NAGY 2021d).

\subsection{Labor and social sustainability}

The comparative advantage of Hungarian fashion companies lies in quality contract work, of which labor cost is a crucial element. After the regime change, the vocational training system collapsed in Hungary and most of the workers employed in sewing operatives were often lowskilled and trained on the job. The wages of fashion workers closely follow the minimum guaranteed salaries and wages. Earning the minimum wage is not attractive for the (younger) workforce as low wages do not reflect the complexity and exactitude required in garment sewing, moreover, being employed in cheap public work also has a stigmatizing effect. From the perspective of an aging workforce Hungary is in a terrible position, according to Anna HANNAUERNÉ SZABÓ. "There is no education. Only bigger fashion companies are able to organize trainings." In her experience, the only three factors that matter to clients are quality, time and cost (DOBOS-NAGY 2021c). Hungary has received 'good press' regarding the respect and enforcement of (labor) laws. It has become increasingly important to Hungarian fashion brands that health and safety at work is guaranteed at companies where their products are made, which have proven to deliver better quality than Romanian, Bulgarian and Ukrainian companies (DOBOS-NAGY 2021e).

During the past few years, minimum wages were raised by the Hungarian government by $8-10 \%$ on a yearly basis. But according to Eurostat, this is still the second lowest wage (442 euros) in 2021 in Europe and just ahead of Bulgaria (EUROSTAT 2021). From the social sustainability point of view, it is a welcome sign that workers are receiving higher and higher wages every year, for a couple of reasons. Firstly, because of the seasonal rhythm of fashion and since local governments announce the actual wage increase at the end of the year (being introduced from January of 2022), companies agree with clients on prices for the following year because collection pieces start being produced more than half a year before hitting the retail segment. It is challenging for companies to economize an 8-10 percent higher salary for their workers when they operate with smaller and smaller margins each year. Through their agent and sourcing representative fashion brands can decide on moving production to a cheaper neighboring country, like Bulgaria or Ukraine. Secondly, having a national, settled minimum wage does not mean that workers are getting that amount of money. There are companies where employee wages are attached to the competition of 'daily norms': if they complete 80 percent of the norm, they get 80 percent of the minimum wage. Hungarian labor rights are decreasingly 
serving the interests of workers. Overtime is often not paid as the overtime law sets a "working hours framework', which in practice means that overtime work in mean, as times is 'slipped down' during 'dead seasons' (DOBOS 2019). Nowadays, according to the Trade Union of Mining, Energy and Industrial Workers, there is no company where workers do not get the minimum wage - daily norms are set to be completed (DOBOS-NAGY 2021e).

"Since the textile and garment industry is labor-intensive in nature, it is a big employer especially in the segment of labor-intensive confection production. Furthermore, in knowledgeintensive technologies, the use of modern communication tools can be attractive for the younger generation as well. Poland, Romania, and Ukraine have slightly lower labor costs than Hungary. Local companies can benefit from the emigration of skilled labor from neighboring countries. Customers are interested in fewer, but better quality and more expensive clothes offered by brands" (DOBOS-NAGY 2021b).

The operation of KÉZMÜ, ERFO and FÖKEFE demonstrates that workers with disabilities are perfectly able to fulfill every step of fashion production, from cutting to sewing. The only difference between normal workers and workers with disabilities is the amount of time required to complete tasks, not quality. Reduced work capacity also entails increased precision in their work, focused attention and in some cases increased tolerance of monotony. 'More and more (fashion) companies are talking about social responsibility, and when they can point to employing workers with disabilities the perception of their value in the public eye also improves'. (DOBOS-NAGY 2021d). This tendency to support social sustainability and inclusive employment is highly favorable for them.

Promoting the employment of people with disabilities by law can also have a negative effect. Law No CXCI. of 2011 declares that companies employing more than 25 people must ensure that $5 \%$ of their employees are people with disabilities. If this condition is not met, the company is required to pay a rehabilitation contribution amount of 1,449,000 Hungarian forints/person/year in 2021 (where the amount is nine times the minimum wage, as set in each case, and the company must pay the compulsory rate of employment for the missing number of disabled employees). Not surprisingly, the (favorable) tax paid by the state system on behalf of people with disabilities has reportedly led to an unjustified rivalry between garment companies (TMTE 2017). As Rozália SULYOKNÉ KRUSPÁN, representative of the Trade Union of the Mining, Energy and Industrial Workers points out, several companies have considered employing people with disabilities in the interests of reducing the tax burden for the company. Nevertheless, by doing so the integration of these workers into the larger community along with facing different working conditions can lead to conflicts as well (DOBOS-NAGY 2021e). It is 
hard to say exactly how many fashion companies are paying the rehabilitation contribution as the Central Statistics Office registers only the number of companies by branch of economic activity (not by persons employed). The CSO counted 7454 registered (2020) and 4954 operating (2019) companies dealing in textile, garment, leather and leather goods.

There is also an unexpressed tension between the workers, the company and fashion brands because of the difference between the prime cost of the garment (the price that the producer receives after each piece) and the final retail price of the garment, which can be 5-8 times higher than the workers' monthly salary. Previously this cost difference was a multiplier of around 2-2.5, and there is a reported tendency that this is growing. But as Hungarian fashion companies are relying on foreign fashion brands, we cannot consider this tension as a threat to relocation tendencies. ${ }^{72}$

The interviewees identified the diminishing prestige of fashion work and low wages as a primary cause of the reduced workforce. Furthermore, public opinion looks at fashion production as being old-fashioned. It will be crucial to raise the level of education and vocational training, with a focus on integrating practical skills for the $21^{\text {st }}$ century. The development of education in terms of connecting 'theory and practice' will be key in winning the younger generation.

\subsection{Technology and capital}

From the point of view of the interviewees, the beneficial factors of Hungarian production are the following: geographical proximity; cost-effectiveness in transport; long-standing tradition in manufacturing; easy, effective and fast communication; the opportunity of collaboration from the design process to product development and final product; keeping deadlines; fast and easy correction of problems and misunderstandings; high work capacity; and a work mentality that they described as being 'we love to meet challenges'.

According to the head of the Textile and Garment Section at VOSZ, the technology facilities at companies that export for 'big brands' are modern and appropriate. "There are several small companies who are actually not able to invest in new technologies. They can only maintain a good position through building stable relationships with clients and contractors" (DOBOS-NAGY 2021a).

\footnotetext{
${ }^{72}$ Note: The prime cost depends mainly on the details and complexity of the garments and the difficulty of handling the designated material. In practice, the garment price is often set by clients based on former estimates and their willingness to pay.
} 
Ildikó MEDGYESSY also underscored the point that virtually every fashion company has tried to come up with own collections and create an own product line with the aim of upgrading, but she described this tendency as a 'stumbling effort'. She does not see the available technology as posing a threat to human labor.

Nonetheless, interviewees also identified various obstacles to the Hungarian fashion industry, such as: the constantly declining number of skilled workforce; the acceptance of higher prices by customers and the market; the offering of favorable prices (labor costs) by neighboring countries (like Serbia and Croatia); the inability of companies to invest in automation even if the technology was available; fluctuating market demand; and the lockup of production capacity, which is hard to plan for most of the time.

\section{Conclusion}

Companies offering premium or high-end products are more likely to re-shore their production. That tendency can be beneficial for Hungarian fashion companies who are specialized in high quality contract work. Longstanding traditions are respected by Western European fashion brands and Hungarian fashion production companies meet the requirement of the high quality, even luxury segment. Several factors that shape relocation decisions (listed above as geographical proximity, cost-effectiveness in transport, long-standing tradition in manufacturing, easy, effective and fast communication, the opportunity of collaboration from design processes to product development and final products, etc.) is favorable for Hungarian fashion production companies. As Hungarian fashion companies offers slightly higher prices for products compared to neighboring countries, the effect of the pandemic and the ceasing of orders can be beneficial for them. It is important to point out the co-dependence between production and retail. On the one hand, some fashion companies reported an increase in clients (fashion brands) and growing orders but on the other hand, others suffered and reported devastating consequences as fashion brands, their main clients, went bankrupt and closed operation. The results of the interviews show divided and opposing results in terms of growing relocation tendencies and the promise of ongoing nearshoring, backshoring and onshoring tendencies.

Labor-intense fashion production is a significant employer, especially in rural areas, of people with disabilities who are fully able to handle every step of fashion production, so in terms of inclusive employment as defined by the $8^{\text {th }}$ goal of the United Nations Sustainable Development ("Promote sustained, inclusive, and sustainable economic growth, full and 
productive employment and decent work for all"), these companies are providing decent jobs in fashion as required.

In consequence of the tensions between social and economic sustainability, my hypothesis is that some sacrifice has to be made at one level. Furthermore, the possibilities of upgrading options for technology development is limited as most fashion companies suffer from a lack of capital.

Automation and new technologies would make Hungarian fashion companies more attractive and that would mean increased productivity and shorter lead times. But this is challenging since local companies suffer from a lack of capital and small orders (tens or hundreds of pieces per model). The need for investment into new technology also came at the worst possible time as companies are suffering from the effect of the ongoing pandemic and uncertainty of the market, while being heavily dependent on foreign fashion brands orders. Even if almost every company tried to upgrade their activity, only a few could move to higher levels of collaboration in terms of OEM, ODM and OBM because of the lack of capital as they are trapped in subcontracting, which is less profitable.

Even if relocation tendencies are boosted by the ongoing pandemic and the crisis, there are several factors that challenge Hungarian fashion companies. One of the most important is the growing lack of workforce and the aging of employees with no possible second generation of workers, since jobs are attached to minimum wages. Working in fashion production is considered to be 'old-fashioned' and not attractive in terms of the complex and precise nature of fashion production. As several interviewees emphasized, one of the most important advantages of Hungarian fashion companies is the experienced workforce who meet the demands of producing even the highest, luxury brands. A second-generation workforce - with less experience - could possibly threaten the established relationships between companies and fashion brands in terms of excellent quality or it could lead to reduced productivity. Development of the vocational training system and investment into retraining would be needed as well.

Another factor worth considering in terms of (re)location of production is the geographical change in the main market of the fashion brands. After receiving feedback from one of her clients, one company's representative (director) turned the spotlight on the growing share of the Asian market (momentarily fashion companies are relying on the re-opened Asian market more than on the European market) by saying: 'there is still a status in buying and wearing clothes that are European' (DOBOS-NAGY 2021a). A switch in market destination can shape (and undermine) relocation tendencies. 
As I have indicated above, relocation came primarily from Western-European fashion companies (especially German) which are suffering from the economic effects of the COVID19 pandemic. A total rebound of the fashion market is unpredictable, and it is really hard to prognose anything concerning changing customer demand. For this reason, stability and the search for new opportunities for fashion companies (home textiles, other industrial segments, functional garments) are needed.

\section{References}

ANDERSSON, J. - BERG, A. - HEDRICH, S. - IBANEZ, P. - JANMARK, J. - MAGNUS, K. H. 2018: Is Apparel manufacturing coming home? Nearshoring, automation, and sustainability - establishing a demand-focused apparel value chain. McKinsey Apparel,

Fashion \& Luxury Group. McKinsey \& Company. Available at: https://www.mckinsey.com/ /media/mckinsey/industries/retail/our\%20insights/is\%20app arel\%20manufacturing\%20coming\%20home/is-apparel-manufacturing-cominghome_vf.pdf (downloaded: 8 March 2021)

ANNER, M. - NOVA, S. 2020: Unpaid Billions: Trade Data Show Apparel Order Volume and Prices Plummeted through June, Driven by Brands' Refusal to Pay for Goods They Asked Suppliers to Make. Research Brief. PennState College of Liberal Arts - Center for Global Workers' Rights [online] Available at: https://www.workersrights.org/wpcontent/uploads/2020/10/Unpaid-Billions_October-6-2020.pdf (downloaded: 8 March 2021)

ANTALÓCZY, K. - SASS, M. 1998: A bérmunka szerepe a világgazdaságban és Magyarországon. Közgazdasági Szemle 45 (7/8): pp. 747-770.

AMIGHINI, A. - RABELLOTTI, R. 2010: How do Italian Footwear industrial districts face globalisation? European \& Planning Studies 14 (4) pp. 485-502.

BOF - MCKINSEY\&COMPANY 2019: The State of Fashion. McKinsey \& Company.

Available at:

https://www.mckinsey.com/ /media/McKinsey/Industries/Retail/Our\%20Insights/The\%2 0State\%20of\%20Fashion\%202019\%20A\%20year\%20of\%20awakening/The-State-of-

Fashion-2019-final.ashx (downloaded: 8 March 2021)

BONACICH, E. - APPELBAUM, R. 2000: Behind the Label: Inequality in the Los Angeles Apparel Industry. Berkeley: University of California Press. 
CHRISTOPHER, M. - LOWSON, R. - PECK, H. 2004: Creating Agile Supply Chains in the Fashion Industry. International Journal of Retail \& Distribution Management 32(8): pp. 367-376.

CLEAN CLOTHES CAMPAIGN 2019: Fig Leaf for Fashion. How social auditing protects brands and fails workers. Clean Clothes Campaign. [online] Available at: https://cleanclothes.org/file-repository/figleaf-for-fashion.pdf/view (downloaded: 8 March 2021)

DEELEY, R. 2021: In Fashion's Global Supply Chain, a Ruthless Race to the Bottom - The Business of Fashion [online] Available at: https://www.businessoffashion.com/articles/sustainability/in-fashions-global-supplychain-a-ruthless-race-to-the-bottom (downloaded: 8 March 2021)

DOBOS, E. 2019: A félmilliós luxusruhákat készítő magyarok sokszor a minimálbért sem kapják meg. hvg.hu [online] Available at: https://hvg.hu/kkv/20191202_stella_meccartney_varroda_ruhaipar (downloaded: 8 March 2021)

DOBOS, E. 2020: Akár nyerhetnek is a magyar ruházati cégek a koronavíruson. hvg.hu [online] Available at: https://hvg.hu/gazdasag/20200826_magyar_ruhaipar_koronavirus (downloaded: 8 March 2021)

DOBOS-NAGY, E. 2021a: Personal interview with Ildikó Medgyessy, Dr., director of Elegant Design Private Limited Company (date: 25 February 2021)

DOBOS-NAGY, E. 2021b: Email interview with representatives of the Hungarian Fashion \& Design Agency (date: 1 March 2021)

DOBOS-NAGY, E. 2021c: Email interview with Anna Hannauerné Szabó, head of Textile and Garments Section of the National Association of Entrepreneurs and Employers (date: 4 March 2021)

DOBOS-NAGY, E. 2021d: Email interview with representative of the KÉZMÜ, ERFO and FÖKEFE nonprofit company (date: 2 March 2021)

DOBOS-NAGY, E. 2021e: Phone interview with Rozália, Sulyokné Kruspán and Szabolcs Beőthy-Fehér, representatives of Trade Union of Mining, Energy and Industrial Workers (Bánya, Energia és Ipari Dolgozók Szakszervezete - BDSZ) (date: 25 May 2021)

EDWARDS, R. - HUNT, T. - LEBARON, G. 2019: Corporate Commitments to Living Wages in the Garment Industry. Sheffield Political Economy Research Institute [online] Available at: http://speri.dept.shef.ac.uk/wp-content/uploads/2019/05/Corporate-Commitments-toLivingWages-in-the-Garment-Industry-SPERI-report.pdf (downloaded: 8 March 2021) 
EURATEX 2020: COVID-19 Outbreak May Cause a 50\% Drop in Sales and Production for the European Textile and Clothing Sector. EURATEX [online] Available at: https://euratex.eu/news/covid-19-may-cause-important-drop-in-sales-and-production/ (downloaded: 8 March 2021)

EUROSTAT 2021: Disparities in minimum wages across the EU European Comission [online] Available at: https://ec.europa.eu/eurostat/web/products-eurostat-news/-/ddn-20210205-1 (downloaded: 8 March 2021)

FRIEDMAN, V. 2018: The Biggest Fake News in Fashion. The New York Times. [online] Available at: https://www.nytimes.com/2018/12/18/fashion/fashion-second-biggestpolluter-fake-news.html (downloaded: 8 March 2021)

FUKUNISHI, T. - YAMAGATA, T. (eds.) 2014: The Garment Industry in Low-Income Countries. An Entry Point of Industrialization, New York: Palgrave Macmillan

FUTUREBRAND 2014: Made In: The value of Country of Origin for future brands [online]. Available at: https://carlobattisti.files.wordpress.com/2015/06/made_in_final_hr.pdf. (downloaded: 8 March 2021)

GEREFFI, G. 2001: Shifting Governance Structures in Global Commodity Chains, With Special Reference to the Internet. American Behavioral Scientist 44 (10): pp. 1616-1637.

GEREFFI, G. - MEMEDOVIC, O. 2003: The Global Apparel Value Chain: What Prospects for Upgrading by Developing Countries? United Nations Industrial Development.

HALL, C. 2020: Where Should Fashion Brands Manufacture Now? - The Business of Fashion [online] Available at: https://www.businessoffashion.com/briefings/china/where-shouldfashion-brands-manufacture-now (downloaded: 8 March 2021)

HANZL, D. - HAVLIK, P. 2003: Textiles in Central Eastern Europe and Russia: A comparative analysis in the European context, Journal of Economics and Business, 6(2), pp. 63 - 88.

KAHN, M. A. 1995: Sustainable development. The key concepts, issues and implications. Keynote paper given at the international sustainable development research conference, 2729 March 1995, Manchester, United Kingdom.

KINKEL, S. - MALOCA, S. 2009: Drivers and antecedents of manufacturing offshoring and backshoring - A German perspective. Journal of Purchasing and Supply Management 15(3):154-165. https://doi.org/10.1016/j.pursup.2009.05.007

KINKEL, S. 2012: Trends in production relocation and backshoring activities: Changing patterns in the course of the global economic crisis. International Journal of Operations \& $\begin{array}{llll}\text { Production } \quad \text { 3anagement } & \text { 696-720. }\end{array}$ http://dx.doi.org/10.1108/01443571211230934. 
LUND, S. - KRISHNAN, M. 2021: Risk, Resilience and Rebalancing in the Apparel Supply Chain Available. The Business of Fashion. [online] Available at: https://www.businessoffashion.com/opinions/retail/risk-resilience-and-rebalancing-inthe-apparel-supply-chain (downloaded: 8 March 2021)

MCFALL-JOHNSEN, M. 2020: These facts show how unsustainable the fashion industry is. WeForum [online] Available at: https://www.weforum.org/agenda/2020/01/fashionindustry-carbon-unsustainable-environment-pollution/(downloaded: 8 March 2021)

MCGUINN, J. - FRIES-TERSCH, E. - JONES, M. - CREPALDI, C. - MASSO, M. KADARIK, I. - SAMEK LODOVICI, M. - DRUFUCA, S. - GANCHEVA, M. - GENY B. 2020: Social Sustainability. Concepts and Benchmarks. Available at: https://www.europarl.europa.eu/RegData/etudes/STUD/2020/648782/IPOL_STU(2020)6 48782_EN.pdf (downloaded at: 25 May 2021)

MCMASTER, M. - NeTTlETON, C. - TOM, C. - XU, B. - QIAO, P. 2020: Risk Management: Rethinking Fashion Supply Chain Management for Multinational Corporations in Light of the COVID-19 Outbreak. Journal of Risk and Financial Management 13(8): pp. 1-16. https://doi.org/10.3390/jrfm13080173.

MCKINSEY \& COMPANY - GLOBAL FASHION AGENDA 2020: Fashion on Climate. How the fashion industry can urgently act to reduce its greenhouse gas emission. McKinsey\&Company. Available at: https://www.mckinsey.com/ /media/mckinsey/industries/retail/our\%20insights/fashion\% 20on\%20climate/fashion-on-climate-full-report.pdf (downloaded: 8 March 2021)

MOLNÁR, J. 2017: A félperiféria szerepe az élőmunka-igényes ágazatok globális értéktermelési hálózataiban. Területi Statisztika 57 (4): pp. 436-464.

MONTERO, J. 2011: Neoliberal fashion: The political economy of sweatshops in Europe and Latin America. Doctoral theses. Department of Geography, Durham University, Durham. TERRE DES FEMMES. 2002: Made in... Eastern Europe. The new 'fashion colonies'. Clean Clothes Campaign [online] Available at: https://cleanclothes.org/resources/nationalcccs/made-in-eastern-europe.pdf (downloaded: 8 March 2021)

NAGY, G. M. 2020: „Jó lenne visszaaludni hajnali 3:20-kor, de nem tudok” - így kerültek utcára a vásárosnaményi varrónők. Available at: https://24.hu/belfold/2020/07/23/vasarosnameny-ruhagyar-varrono-bezaras/ (downloaded at: 26 May 2021) 
NAPIER, E. - SANGUINETI, F. 2018: Fashion Merchandisers' Slash and Burn Dilemma: A Consequence of Over Production and Excessive Waste? - Rutgers Business Review 3 (2): pp. $159-174$

OHLIN, B. 1967: Interregional and International Trade. Harvard Economic Studies. 39. Cambridge, MA: Harvard University Press.

PORTER, M. 1990: The Competitive Advantage of Nations. New York: Free Press

RIFKIN, J. 1995: The End of Work. The Decline of the Global Labor Force and the Dawn of the Post-Market Era. - New York: Putnam Publishing Group

ROBINSON, P. - HSIEH, L. (2016). Reshoring: a strategic renewal of luxury clothing supply chains, Operations Management Research (9) pp. 89-101

SCHMITZ, H. 2006: Learning and Earning in Global Garment and Footwear Chains. European Journal of Development Research 18(4) pp. 546-571. DOI: 10.1080/09578810601070688. TEODORO, A. - RODRIGUEZ, K. 2020: Textile and garment supply chains in times of COVID-19: challenges for developing countries. UNCTAD [online] Available at: https://unctad.org/es/node/3024 (downloaded: 7 March 2021)

THOMAS, D. 2008: Deluxe. How Luxury Lost Its Luster. New York: Penguin Books

TMTE (Textilipari Müszaki és Tudományos Egyesület). 2017: Könnyüipari Szakmai Nap Available at: https://docplayer.hu/47978803-Konnyuipari-szakmai-nap-2017.html (downloaded: 25 May 2021)

TMTE - MKSZ 2020: Felmérés a hazai könnyüipar - elsősorban a textil és ruházati szektor érintettségéröl a koronavírus járvány kapcsán - TMTE [online] Available at: http://tmte.hu/_userfiles_tmte/covid-19_hatasa_a_konnyuipari_vallalkozasokra_-

_felmeres_es_javaslatok.pdf (downloaded: 8 March 2021)

UN GLOBAL COMPACT. (n.d.): Social sustainability. Available at:

https://www.unglobalcompact.org/what-is-gc/our-work/social (downloaded: 8 March 2021)

VALLANCE, S. - PERKINS, H. C. - DIXON, J. E. 2011: What is social sustainability? A clarification of concepts. Geoforum $42 \quad$ (3) pp. 342-348. https://doi.org/10.1016/j.geoforum.2011.01.002.

WALLERSTEIN, I. 1974: The Modern World System: Capitalist Agriculture and the Origins of the European World Economy in the Sixteenth Century. New York: Academic Press

WATTS, R. 2021: Germany to fine firms for rights breaches in supply chains. - Deutsche Welle. [online] Available at: https://www.dw.com/en/germany-to-fine-firms-for-rights-breachesin-supply-chains/av-56553801 (downloaded: 8 March 2021) 
WORLD TRADE ORGANIZATION. 2020: World Trade Statistical Review 2019 [online] WTO, Available at:

https://www.wto.org/english/res_e/statis_e/wts2019_e/wts19_toc_e.htm (downloaded: 8 March 2021) 


\title{
Social sustainability as a synonym for social flexibility in the international context - The case study of Ireland Katalin NÁDAS-NAGY ${ }^{73}$
}

\begin{abstract}
The research seeks to revisit the relevance of social sustainability in the international context. It explores the concept's theoretical and practical impacts from the perspective of analysing nation-states' international position by investigating the states' competitiveness. Social factors are most often used to be applied as a measuring tool of development level or competitiveness of a country, while partially different social goals are declared by sustainability perspective. The paper focuses on these two policy-shaping goals of nation states and finds out their overlapping and altering social impacts on states' international position and behaviour.

Social relating factors of social sustainability and competitiveness are compared as the determinant factor to adapt nation states themselves to the given global context and to become a successful global economic actor by enforcing their own national interest. This approach motivates the macro level research focus on social sustainability while considering the fluidity of the international system as a complex exogen factor.

The Celtic Tiger's unexpected economic performance and international position-change from the near past are used as examples and analysed from the perspective of social sustainability.
\end{abstract}

Keywords: social sustainability, international social flexibility, Ireland, sustainable competitiveness, international relations, social conditions of competitiveness, GSDI, GCI, SPI

\section{Introduction}

The modern nation-states' social features play an increasingly important role in their international position in political and economic terms as well. The current world economic system (CALHOUN - DERLUGUIAN 2011) generated fundamental changes in national economies' main pillars and mechanisms in the last few decades. Consequently, national economies became mostly market- and competitiveness-driven and built up through the requirements of the current meaning of competitiveness (POPESCU et al. 2017). In the $21^{\text {st }}$ century, these factors determine and mainly cover the local social policies in the developed part of the world as instruments for achieving a stable and safe position globally. Deep globalization and the explosion of digitalization has re-shaped the global supply chains (UM 2021) and generated new challenges regarding the natural environmental and long-term sustainability in any sense. However, instead of the widening debate on sustainable development, the concept of social sustainability seems to still lack a widely accepted, unified definition (HOPWOOD et al. 2005; DEMPSEY et al. 2016; EU POLICY DEPARTMENT FOR ECONOMIC, SCIENTIFIC AND QUALITY OF LIFE POLICIES DIRECTORATE 2020). This fact illustrates the complexity of the topic and the deep interconnection between the policies' effects in other fields. Preferences determine the policy-making processes, but every decision has a

\footnotetext{
${ }^{73}$ Corvinus University of Budapest, Doctoral School of International Relations and Political Science, PhD student katalin.nagy3@stud.uni-corvinus.hu
} 
clear impact on the other dimensions of the life and makes significant impacts on the society as the basis of every national performance.

As Marcuse illustrates, sustainability as a goal means the preservation of the current status quo of the state's and community's situation (MARCUSE 1998). Following this idea, the paper aims to explore these overlapping impacts on society from the competitiveness and social sustainability perspectives/goals in parallel, by implementing the hypothesis on the direct correlation between the determining success of competitiveness on social sustainability and back and forth. If their social conditions are the same and their correlation is quite evident, the substantive state sustainability policies are in theory easy to design. But if their social factors are differing, the countries find themselves in a difficult position to decide if they want to be socially sustainable or economically successful. The second scenario should create a particularly uncomfortable position for states, but also a really bad news for the global environment. The hypothesis is challenged with the case of Ireland and the society's sustainability behind its economic success.

Competitiveness provides the research context as a complex and well-defined indicator containing numerous social indicators. Social conditions of being competitive are more and more included and discussed in the competitiveness indices since 2011, when the World Economic Forum (WEF) redesigned its Global Competitiveness Index (GCI) and implemented certain sustainability indicators to the original index design (SCHWAB - WEF 2011-2019). As an alternative methodology, the Global Sustainable Competitiveness Index (GSCI) was launched in 2013 based on more sustainability factors and less economic ones (SOLABILITY 2013) to realise the complex and multidisciplinary approach on states' global economic performances and their sustainability conditions. Mentioning only the included indices, the sustainable progress index (SPI) from 2019 is created by the EU based on the UN Sustainable Development Goals from 2015 (UN SDGs 2015). The latter one represents the pure social sustainability goals in the current paper.

The Human Development Index (HDI) (SEN 1994) ranking position of a state seems to become obsolete and can only explain partially the states' real conditions but can easily mislead the investigation (KELLEY 1991; RAVALLION 1997; NEUMAYER 2001, 2010). For instance, the role of the democratic values, as the HDI and former competitiveness analysis's key pillars, seems to lose its influence on the states' success (f.i. economic success of China and Singapore). Consequently, the research analyses the society-relating factors of (sustainable) competitiveness of GSCI and GCI, and compares them with the indicators of Sustainable 
Progress Index (SPI) as a control group of factors in social sustainability in order to explore the similarities and altering points of competitiveness and pure social sustainability.

First, the paper discusses the relevant literature on social sustainability, demonstrating the key role of social indicators of any national actions and clarifies the current understanding and meaning of the social factors of competitiveness and the sustainability conditions of societies. In the research chapter, the analysed and compared indicators and indices are introduced. Continuing with the comparison of the indices, the overlapping and altering conditions are collected and analysed. The next chapter discusses the Irish case study specifically to illustrate the relationship of the economic and social policy goals' results on competitiveness, as one of the most remarkable examples in economic and development success during the last few decades. Finally, the last phase sums up the findings and conclusions of the research. The analysis is made from a state perspective and discussing the state-level impacts of the analysed research fields in every sub-chapter of the paper with special focus on the Irish case.

The conclusion of the research offers the need for a switch in the approach toward the challenge of sustaining states' communities in themselves and the policies behind countries' sustainable global performances. By using Ireland as case study, the research explores the correlation of sustainable competitiveness and sustainable progress based on social factors and their relationship, exploring the sustainability of the society behind them.

\section{Society as the common source of everything}

\subsection{Approaches on social factors of the sustainability debate}

Society is the base resource of everything. Hence, society deserves a highlighted position in sustainability research, meaning it gets a special investigation separated from the general sustainability and competitiveness debate (GRIESSLER - LITTIG 2005; CUTHILL 2009). especially because the new global economic system generated serious social trends internationally. For instance, the national boundaries lost their relevance, the diaspora policies and properly educated workforce importing strategies of states to fill up the possible lack of workforce run on higher intensity (IRISH DEPARTMENT OF FOREIGN AFFAIRS AND TRADE 2015). Because of these kinds of reasons, this research deals with society not only as set of surrounded indicators in the sustainability and competitiveness debate, but as a core factor of national performances in any terms, which means social policies with social development goals are a core generator of every other policy. However, some researchers force the policybased investigation of social sustainability (MURPHY 2012). Although, because of the 
limitations of the paper, specific policies are only mentioned in this research, instead their results are analysed through the implemented indices.

Every activity of a state is built up on the members of the community. Beyond the proper workplaces for qualified workforces and the available quality of life, society exists as a unit, as an organization of people and such, reflecting and influencing all the circumstances around itself. The sustainability debate, including the social sustainability dimension, seeks to catch this interconnection of social, economic and environmental dimensions of our life, however, during the evolution of the concept it is implemented in different ways and weights the three pillars (FOLADORI 2005). As the researchers tend to underline, the concept has no clear, widely accepted definition, but all the research evaluates special definitions and meanings of the notion (BOSTRÖM 2012; DESPOTOVIC et al. 2016; EU POLICY DEPARTMENT FOR ECONOMIC, SCIENTIFIC AND QUALITY OF LIFE POLICIES DIRECTORATE 2020). The multidimensional approach dominates the literature, while the one-pillar model used to refer to society as the cause of ecological and other sustainability problems (Figure 12 and Figure 13). Also, more and more researchers highlight the fact that social sustainability has to be discussed in itself, as a unique and individual topic, such as economic development for instance. This research represents a kind of crossover between these approaches as focusing on the society's sustainability but investigating it from a multidimensional point of view of the applied indices.

The social sustainability pillar's factors refer to different issues than societal sustainability does. In the first case, society is part of a complex interaction as a pillar, while the second approach emphasizes the sustainability of the community itself in the given environmental and economic context. During the research, the Irish competitiveness performance is utilized to illustrate the relation between economic and societal sustainability behind a successful economy. As GRIESSLER and LITTIG (2005) discuss, the sustainability level of society suggests the quality of the available lifestyle and level of life for the members. As such, the two mentioned approach on sustainability with society relations are undistinguished and unseparated.

Certain researchers handle social sustainability as analytical tool, while others investigate it as individual research field. Instrumental approach is found in the UN Sustainable Development Goals, while analytical perspective is demonstrated mostly in urban sustainability research (DEMPSEY et al. 2011), where the goals and needs of the community are also included to the debate. Based on BOYER et al.'s work (2016), the current research deals with social sustainability in the way where social sustainability plays a key role in the economic and 
environmental sustainability of the country. From this perspective, society is a foundation and number one resource of being sustainable in the two other fields - especially because the case country's story suggests this kind of correlation behind the Irish economic miracle as well. By the hypothesis, the determining role of SS is also mentioned, as the social changes generate directly and visibly changes in the economic and environment field as well.

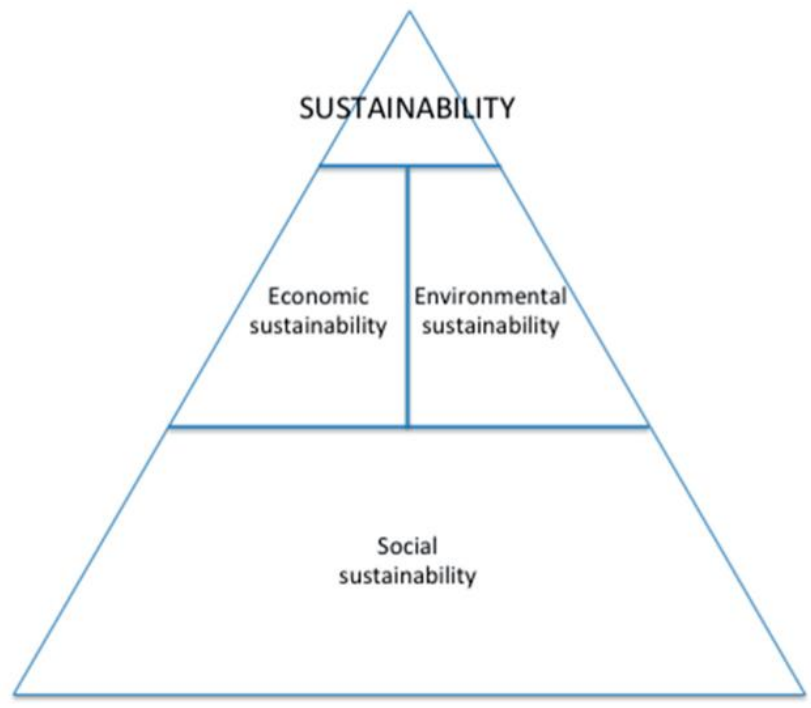

Figure 12: Social Sustainability as a Pre-Condition for Environmental and Economic Sustainability. Source: BOYER et al. 2016, p.7.

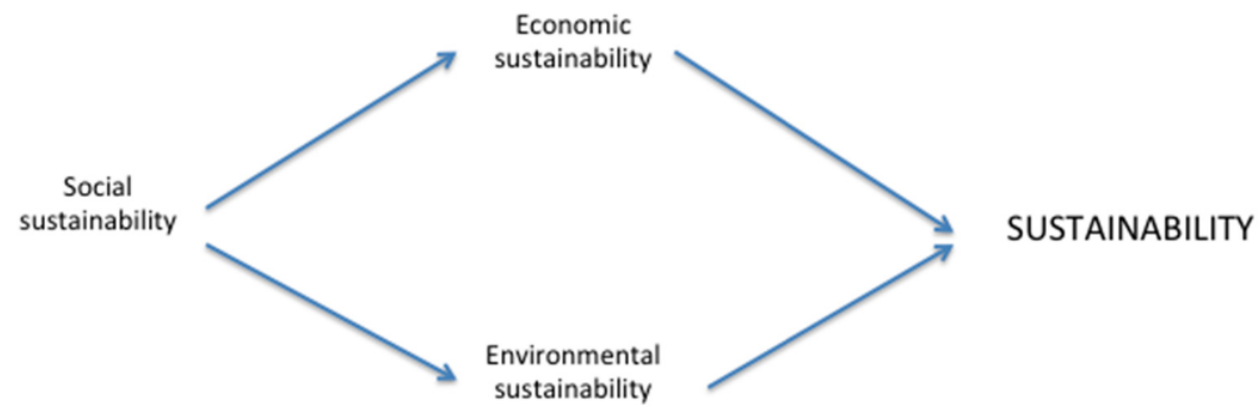

Figure 13: Social Sustainability as the Casual Mechanism of Economic and Environmental Change. Source: BOYER et al. 2016, p.8.

As THORE and TARVERDYAN (2016) emphasize in their research, one of the most doable ways to measure the effectiveness of sustainability goals are policies and their measurable results in indicators. This approach is crucial in exploring the connection between practical and theoretical faces of sustainability-driven policies. This point of view has relevance in the Irish case as well, especially because while the direct correlation between their social and education policy reforms (IRISH NATIONAL ECONOMIC AND SOCIAL COUNCIL 1981; O'CONNOR 2014) and the Celtic Tiger's miracle (BATTEL 2003; MURPHY - OESCH 2018; 
JOHNSTON et al. 2019) is discussed from competitiveness and economic perspective, and the sustainability relevance of these policies are mostly neglected.

Current research focuses on social sustainability with the meaning of sustainable communities in themselves. Such as the sustainable city and community studies, this fraction of social sustainability stresses the specific social factors of making a community sustainable as a group of members with different demographic and lifestyle features but with many similar challenges, living at the same area and circumstances. (DEMPSEY et al. 2011; DESPOTOVIC et al. 2016; HALE et al. 2019). If a community is not sustainable in itself, all the other pillars of sustainability are out of the debate and the mission is unrealizable. Probably this condition is valuable in all the three pillars of sustainability.

As current literature keeps emphasizing, sustainability needs creativity and alternative solutions, while the number one motivator and generator of the current global economy is innovation as well. This means that if a nation state's society bears these features and the necessary infrastructural and institutional environment is available, this community is sustainable and competitive by definition. But as reality demonstrates, the formula is not that simple, although the SGCI tries to cover the whole set of these issues at the same time, the existence of creativity and having a sustainable economy do not necessarily overlap each other.

\subsection{The idea of social flexibility}

As the researcher comes from the field of international relations, the social sustainability debate is complemented with international context, such as the international position of states or their abilities and capabilities to act in certain ways. The Irish case illustrates the close interaction of the economic development and the international position of the country. Based on this link, the research suggests that if a country's economic performance is sustainable, then its international position is as well. Also, the social conditions of being competitive covers partially the same conditions of being sustainable and socially developed by definition. These interconnections of the fields suggest a deeper meaning of social indicators in the sustainability debate. Beyond the already discussed social indicators and their roles in sustainability, this feature of a society means more. Namely, the more sustainable society can react more easily to outside effects and can adapt in the new circumstances. That is the meaning of social flexibility. It is staying somewhere between social conditions of sustainability and competitiveness. It is more than only servicing factor of the sustainability goals. Basically, the overlapping social indicators of sustainability and competitiveness and the infrastructural and institutional environment for their realization. 
The research seeks to find evidence to the suggested notion and prove the existence of this adaptation ability of nation states by assuming that if a nation state's competitiveness and social sustainability level is high, the flexibility has to be high and to mean a stable and strong international position as well.

\section{Research - social sustainability or/and economic success}

\subsection{Research methodology}

The current research aims to explore the relationship between the conditions of social sustainability and competitiveness, especially because some previous, statistical research finds that at certain points and indicators, the two goals are in serious contradiction. BOSTRÖM's research (2012) on the conceptualisation and analysation of social development and sustainability demonstrates the unclear features of the theory. Also, he underlines the good increments of this flexibility of the concept. The other significant part of the social sustainability literature is focusing on the direct links between society and economic performance, as emphasizing the kind obvious interconnection between the two main systems of a country (KAHN 1995; SACHS 1999; KETSCHAU 2017).

H0: Based on the referred research above and the well-known negative consequences/effects of economic competitiveness on environment and on the minimum conditions of social sustainability, as a goal is in serious contradiction with competitiveness. The GCI's new version completed with sustainability indicators obviously shows kind of harmony with social sustainability goals of the UN SDGs, but showing significant alterations in the ranking regarding GSCI ranks.

H1: If a country is socially sustainable it means that its competitiveness is in proportion and in parallel, it follows this sustainability feature and is based on the already developed social conditions The state is able to reach a high level of competitiveness. Also, the converse scenario has to be true: the higher level of competitiveness means the higher level of social sustainability.

During the research, the original indicator set of GCI and GSCI are compared and understood in the context of the sustainability of societies.

Measuring and benchmarking in sustainability is a difficult task to do. (EU POLICY DEPARTMENT FOR ECONOMIC, SCIENTIFIC AND QUALITY OF LIFE POLICIES DIRECTORATE 2020). Firstly, because the conditions and circumstances are constantly changing around us, while for many issues we have no proper and available data. Hence, the current research narrows the research field to economic success and its social conditions to 
understand the connection between development sustainability and sustainability of the society in the case of Ireland.

Following the aim of the research, the analysis focuses on the similarities and alterations of GSCI' social indicators and the GCI's ones. Moreover, these indicators are compared with the pure social sustainability factors without the competitiveness goals. The theoretical analysis focuses on the different indices' socially relating indicators by their contents and their measuring factors as well. Sustainable Progress Index serves as a counter-, or reverence point in the research, representing the "societal sustainability", or the pure sustainable society's conditions.

The social indicators of GCI and GSCI indices are filtered and compared. The analysis of each index is justified by their same research focus (competitiveness) and their different research methods. A kind of objective factor set is created to understand the sustainability of a society in itself. The analysis focuses on the similarities and alteration in order to declare the direction and strength of correlation between social conditions of sustainable competitiveness and social sustainability.

\subsection{Social impacts and factors of sustainable progress index (SPI)}

Sustainable Progress Index is launched by the EU policy-making department, as a measurement tool in the sustainability debate, focusing on $15 \mathrm{EU}$ member countries, based on the UN 17 sustainable development goals from 2015 (the social pillar indicators can be seen in Table 6). The analysis is based on mostly Eurostat and OECD data, which makes the countries comparable. Also, the speciality of the index is including the most developed countries of the EU only. Hence, the index seeks to illustrate the fact that even in the developed countries, the sustainable development goals need more attention and more direct policies to reach them. This hidden message of the index can be interpreted as a significant and real gap between economic success and sustainability. However, in the top ranked countries' overlaps are remarkable.

As the following table contains, many of the social sustainability conditions belong to specific requirements of economic success. Among the others, the poverty rate, the GINI Index, or the level of corruption and the stability of the political environment play key role in analysing the competitiveness performance of nation states too. Meaning in theory that social and societal sustainability require similar conditions than the currently used notion of competitiveness. 


\begin{tabular}{|c|c|}
\hline $\begin{array}{l}\text { UN sustainable } \\
\text { development goal }\end{array}$ & indicators \\
\hline & $\begin{array}{l}\text { Poverty rate after taxes and transfers; poverty line } 50 \% \text { (\% of } \\
\text { population), } \\
\text { Share of severely deprived people } \\
\text { People living in households with low work intensity, } \\
\text { People living in a dwelling with leaky roof, damp walls, floors or } \\
\text { foundation, etc. (\% of population) }\end{array}$ \\
\hline & $\begin{array}{l}\text { Prevalence of obesity, BMI }>30 \text { ( } \% \text { of adult population) } \\
\text { Cereal yield }(\mathrm{kg} / \mathrm{ha}) \\
\text { Ammonia emissions from agriculture } \\
\text { Gross nutrient balance on agricultural land } \\
\text { Area under organic farming ( } \% \text { of UAA) }\end{array}$ \\
\hline & $\begin{array}{l}\text { Life expectancy at birth, total, years, } \\
\text { Adolescent fertility rate (births per 1000, age 15-19) } \\
\text { Subjective wellbeing (average ladder score) } \\
\text { Smoking prevalence (\%, aged } 15+\text { ) } \\
\text { Road traffic deaths (per 100,000) } \\
\text { Self-reported unmet health needs (\% of population) } \\
\text { Deaths from NCDs (per 100,000) } \\
\text { Suicide Rate } \\
\text { Alcohol Consumption (litres per capita, age } 15+\text { ) }\end{array}$ \\
\hline & $\begin{array}{l}\text { Tertiary education (\% of population, age } 30-34 \text { ) } \\
\text { PISA Score } \\
\text { Employment rate of recent graduates } \\
\text { Adult participation in learning (\%) } \\
\text { Early leavers from education and training }\end{array}$ \\
\hline 5 GENDER & $\begin{array}{l}\text { Proportion of seats held by women in national parliaments }(\%) \\
\text { Proportion of women in senior management positions }(\%) \\
\text { Gender pay gap in unadjusted form (\% of male hourly wages) } \\
\text { Women who feel safe walking in their area alone at night } \\
\text { Gender employment gap (5) } \\
\text { Rate of female years of education to male mean years (\% of males), } \\
\text { population aged } 25 \text { and above }\end{array}$ \\
\hline 10 REEUCED & $\begin{array}{l}\text { Gini index } \\
\text { Household debt, \% NDI } \\
\text { Palma index } \\
\text { EU Social Justice Index }\end{array}$ \\
\hline
\end{tabular}




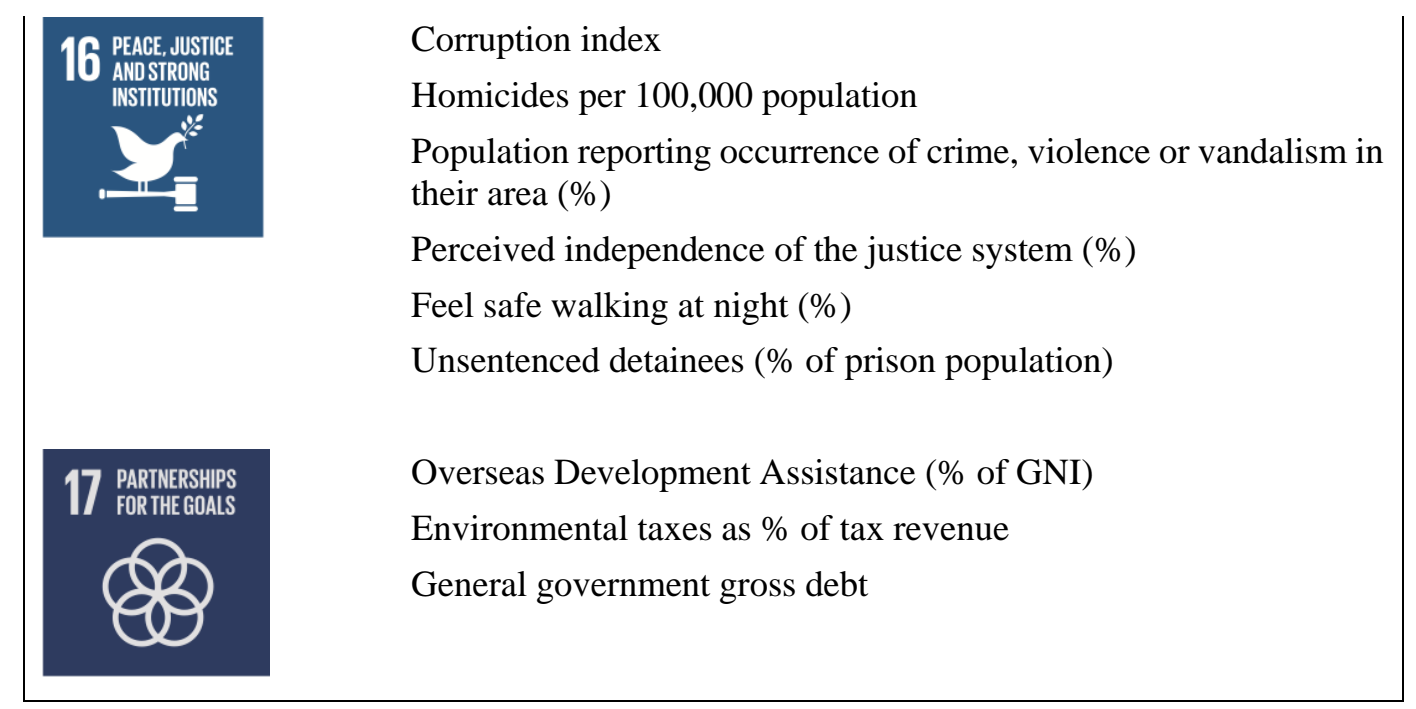

Table 6: List of SPI's social pillar indicators.

Source: Edited by the author based on the SPI report (SOCIAL JUSTICE IRELAND 2020).

\subsection{Social indicators of (sustainable) competitiveness}

Sustainability refers primarily to the relationship between society, economy and the natural environment. However, the concept is extended continuously by novel approaches coming from different fields. As a sub-topic of sustainability research, social sustainability has gathered increasing attention in the last few decades and took numberless critics and comments on the meaning and methods of the concept.

Competitiveness is one of the key notions of the $21^{\text {st }}$ century's economy. In the deeply globalized and digitalized economic environment, the main feature of a national economy refers to the conditions of being able to keep the race and making sure the constant development. Concretely, the jobs and workforce with high added values, the language skills and managerial skill means the main foundations of a national economy's competitiveness. As it is noticed many times, the innovation and creativity capacities play crucial role in connecting to the global economic system in a competitiveness and successful level - based on the currently applied indices.

The indices with a competitiveness focus were launched during the Cold War. Two competitiveness schools exist, with quite the opposite approaches. While the American school (based on Michael PORTER's main concepts) builds up its arguments to the outputs, the World Economic Forum's approach tends to focus on the conditions of being competitive (THORE TARVERDYAN 2016). A third school was started recently as the alternative measuring tool of global competitiveness in the institute of SOLABILITY (2020). 
GCI was revisited in 2011 and later 2013. During these re-shapings, new indicators were included to the data set as the factors and measuring tools of sustainability. The current index contains the social focus indicators listed in Table 7. The indicators were selected based on their relevance to the social sustainability indicators stemming from SPI.

\begin{tabular}{|c|c|}
\hline GCI Pillar & indicators \\
\hline $\begin{array}{l}\text { INSTITUTIONS } \\
\text { Security }\end{array}$ & $\begin{array}{l}\text { Organized crime } \\
\text { Homicide rate }\end{array}$ \\
\hline Social capital & Social capital \\
\hline $\begin{array}{l}\text { Checks and balances } \\
\text { Transparency } \\
\text { Property rights }\end{array}$ & $\begin{array}{l}\text { Freedom of the press } \\
\text { Incidence of corruption } \\
\text { Property rights } \\
\text { Intellectual property protection }\end{array}$ \\
\hline Future orientation of government & $\begin{array}{l}\text { Government's responsiveness to change } \\
\text { Government long-term vision }\end{array}$ \\
\hline $\begin{array}{l}\text { INFRASTRUCTURE } \\
\text { Utility infrastructure }\end{array}$ & $\begin{array}{l}\text { Exposure to unsafe drinking water } \% \text { of population } \\
\text { Reliability of water supply }\end{array}$ \\
\hline $\begin{array}{l}\text { HEALTH } \\
\text { Healthy life expectancy }\end{array}$ & Healthy life expectancy \\
\hline $\begin{array}{l}\text { SKILLS } \\
\text { Current workforce } \\
\text { Skills of current workforce } \\
\text { Future workforce } \\
\text { Skills of future workforce }\end{array}$ & $\begin{array}{l}\text { Mean years of schooling } \\
\text { Extent of staff training } \\
\text { Quality of vocational training } \\
\text { Skillset of graduates } \\
\text { Digital skills among active population } \\
\text { Ease of finding skilled employees } \\
\text { School life expectancy } \\
\text { Critical thinking } \\
\text { Pupil-to teacher ratio in primary education }\end{array}$ \\
\hline $\begin{array}{l}\text { LABOUR MARKET } \\
\text { Flexibility }\end{array}$ & $\begin{array}{l}\text { Active labour market policies } \\
\text { Workers' rights } \\
\text { Ease of hiring foreign labour }\end{array}$ \\
\hline $\begin{array}{l}\text { INNOVATION CAPACITY } \\
\text { Interaction and diversity } \\
\text { Research and development }\end{array}$ & $\begin{array}{l}\text { Diversity of workforce } \\
\text { State of cluster development } \\
\text { Scientific publications } \\
\text { Patent applications } \\
\text { R\&D expenditures \% GDP } \\
\text { Research institutions prominence }\end{array}$ \\
\hline
\end{tabular}

Table 7: The social related indicators of Global Competitiveness Index. Source: GCI 2019

The Global Sustainable Competitiveness Index (GSCI) were launched in 2013 as the most complex tool for measuring competitiveness and sustainability at the same time. Like this, the two indices are seemingly focusing on the same topic, but because of their methodology and indicator set, they can be seen as the two sides of the same coin or the two ending points of the 
same scale, such as the GCI, which is analysed as the economic, GSCI as the sustainability part of the sustainable economic success debate.

GSCI is built up five pillars and covering the main competitiveness conditions, while including the three main pillars of sustainability. As the following tables illustrate, there are significant overlaps between the two indices, but GSCI contain more sustainability elements, especially considering the social factors of sustainability and competitiveness. Consequently, in GSCI, the social capital, the intellectual capital and innovation, and the governance efficiency pillars of the index covers social sustainability indicators (see Table 8, Table 9, and Table 10).

\begin{tabular}{|l|l|}
\hline \multicolumn{2}{|l|}{ Sociel Cepitifl Indicoifors } \\
\hline Aging society & Overweight \\
\hline Birth per woman & Peace Index \\
\hline Child mortality (below age 5, death per 1000) & Press Freedom Index \\
\hline Doctors per 1000 people & Prison population rate (per 100'000 people) \\
\hline GINl coefficient (income distribution inequality) & Public health expenditure of total expenditure \\
\hline Homicide rate (per 100'000 people) & Civic disease risk \\
\hline Hospital bed availability & Suicide rate \\
\hline Human rights index & Teen moms \\
\hline Income quintile ratio & Top 10 \% income share \\
\hline Life expectancy & Women in parliament (\% of MPs) \\
\hline Life satisfaction index & Violent assaults/100000 \\
\hline Lower middle class income share (2nd 20\%) & Women in management positions \\
\hline Nurses per 1000 people & Health care efficiency index \\
\hline Aging society & Drug use prevalence \\
\hline Birth per woman & Freedom for and from religion \\
\hline Obesity rate & \\
\hline
\end{tabular}

Table 8: The social indicator set of Global Sustainable Competitiveness Index.

Source: GSCI 2020

\begin{tabular}{|c|c|}
\hline Cost of business start-up & R\&D spending \\
\hline Education spending (\% of GDP) & School dropouts secondary \\
\hline High tech exports & Secondary education enrolment \\
\hline New business registrations per 1 million people & $\begin{array}{l}\text { Spending on education (\% of state } \\
\text { expenditure) }\end{array}$ \\
\hline Patent applications (per GDP) & Spending per student (\% of per capita GDP) \\
\hline Patent applications per 1 million people & Tertiary education enrolment \\
\hline Primary education completion & Trademark applications \\
\hline Primary student repetitions & Pisa Test Results \\
\hline Pupil gender ratio & Females with secondary education \\
\hline Pupil-teacher ratio & R\&D spending \\
\hline R\&D FTEs per million people & School dropouts secondary \\
\hline
\end{tabular}

Table 9: The intellectual capital and innovation indicators of Global Sustainable Competitiveness Index. Source: GSCI 2020 


\begin{tabular}{|l|l|}
\hline \multicolumn{2}{|l|}{ Governance Efficiency Indicators } \\
\hline Access to electricity & $\begin{array}{l}\text { Market fluctuation exposure: company value (\% of } \\
\text { GDP) }\end{array}$ \\
\hline Austerity Index & $\begin{array}{l}\text { Market fluctuation exposure: stock trading volume } \\
\text { (\% of GDP) }\end{array}$ \\
\hline Bank capital-asset ratio & Military spending (\% of total government spending) \\
\hline Bribery payments - \% of businesses & Mobile communication availability \\
\hline Ease of doing business & Non-renewable resource income dependency \\
\hline Employment in the manufacturing sector & Population (total) \\
\hline Employment in the service sector & Poverty development \\
\hline GNI (total) & Quality of public services \\
\hline GNI per capita & Rail network per area \& population \\
\hline Government debt & TI CPI Index \\
\hline Imports (\% of GDP) & Unemployment \\
\hline Internet availability & Debt service (\% of government expenditure) \\
\hline Investments & Democracy Index \\
\hline Manufacturing value added & \\
\hline
\end{tabular}

Table 10: The governance efficiency indicators of Global Sustainable Competitiveness Index. Source: GSCI 2020

\subsection{Meeting points and differing factors}

The meaning of social sustainability and sustainable competitiveness can be described with the help of their indicator sets. As the above detailed indices illustrate, every school and research manage different approaches and data set to explore sustainability of nation states. Competitiveness is analysed in GCI mostly from an economic and financial perspective, albeit the significant intention to harmonize the index with sustainability studies. Also, GCI designed up to mostly subjective data and opinions of experts and leaders. However, the GSCI index seeks to build up almost $100 \%$ on qualitative data and analysed them in the same weight.

Both indices have truth and both of them could be criticised in many ways. At the same time, it seems that their indicators differ much less than it seems at first glance, but the data collection and analysis methodology realise a different output in the ranking of nation states. Hence, the hypothesis has right, in indicator level, social sustainability goals and competitiveness goals need so similar social basis to be realised.

Although, instead of all the criticisms and faults of the indices, these global indicators can suggest rightly the trends and positions of states from the given perspectives. 


\section{Ireland - case study}

\subsection{Why Ireland?}

Ireland is one of the few so-called small and vulnerable states, which was able to manage an unexpected economic development and achieve a high level of international position in the last two decades. However, the last financial crisis hit the Celtic Tiger as well, still it remains a relatively stable and competitive actor of the global system. Many researchers discuss the reasons behind its success, mentioning the education and social policy reforms starting from the 1970s to attributing to luck that the country started on the digitalization trend on the right time. Effectively, both of these statements have truth and both of these factors played crucial role in the success. In general, the core of the Irish miracle was the ability to stop the pathdependency circle and to break out from the previous, economically weak and politically dependent position by re-shaping the society of the country. Researchers concur on the fact that the social reforms provided the basis for the following economic reforms launched in the Irish national economy.

The current paper seeks to find out the sustainability of this extraordinary performance of Ireland from the following reasons: if the Irish recipe seems sustainable, it could provide a good example and good practice for other so-called small and vulnerable states to break out from the path-dependency circle; if the Irish case can prove the direct and positive correlation between social sustainability and competitiveness, then the mutual interaction of these policy-shaping fields should be harmonized more worldwide; if the correlations doesn't exist or negative, it means that nation states' governments have to decide between being competitive or being sustainable - in social terms firstly.

\subsection{The Irish performance in the reflection of GCI, SGCI and SPI}

Ireland changed its position radically on the GCI ranking around the 2000s. The so-called Irish miracle achieved a visible and measurable point in economic perspective. However, to make the indices comparable, the state's ranking is showed here mostly after the crisis. 19992001 are illustrated as counter point from the era before the financial crisis. This data selection is also justified with the fact of the GSCI index has been started in 2012, so the comparison is possible only from this year.

As the blue line shows in Figure 14, the GCI ranking of Ireland, the orange one sign the GSCI position of the country. The data and the positions show no parallel, neither any correlation. However, based on the indicators, they analysis almost the same factors. 


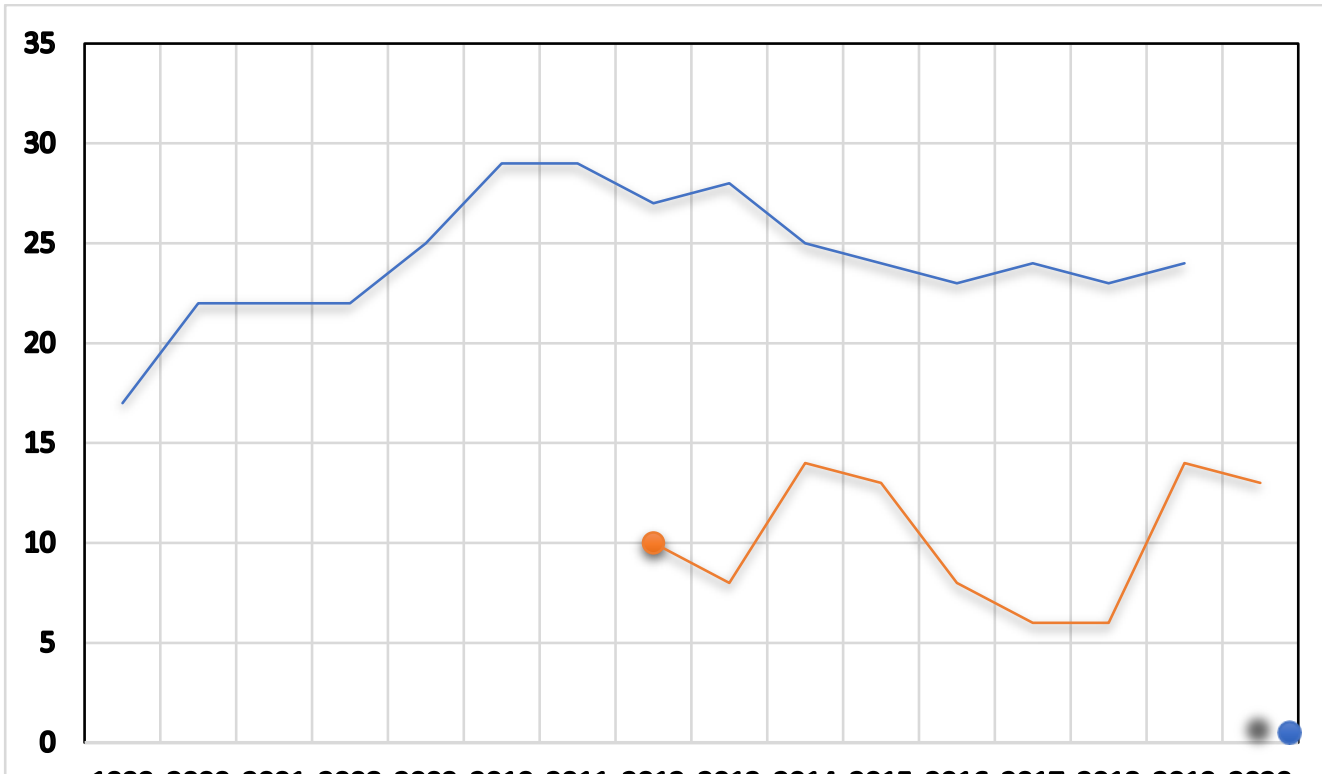

1999200020012008200920102011201220132014201520162017201820192020

Figure 14: Irish rankings on GCI 1999-2020. (blue line) Source: GCI REPORTS 1999-2020 Irish rankings on GSCI 2012-2020. (orange line) Source: GSCI REPORTS 2012-2020

The Sustainable Progress Index represent the UN SDGs in the EU context. The measuring probe tries to design a statistical basis for investigating the nation states' performance regarding the 17 SDGs. This index plays important role in the current research firstly with its indicators, instead of its ranking. Especially because this index contains only EU countries. Albeit, stay here the ranking of Ireland among the most developed EU countries.

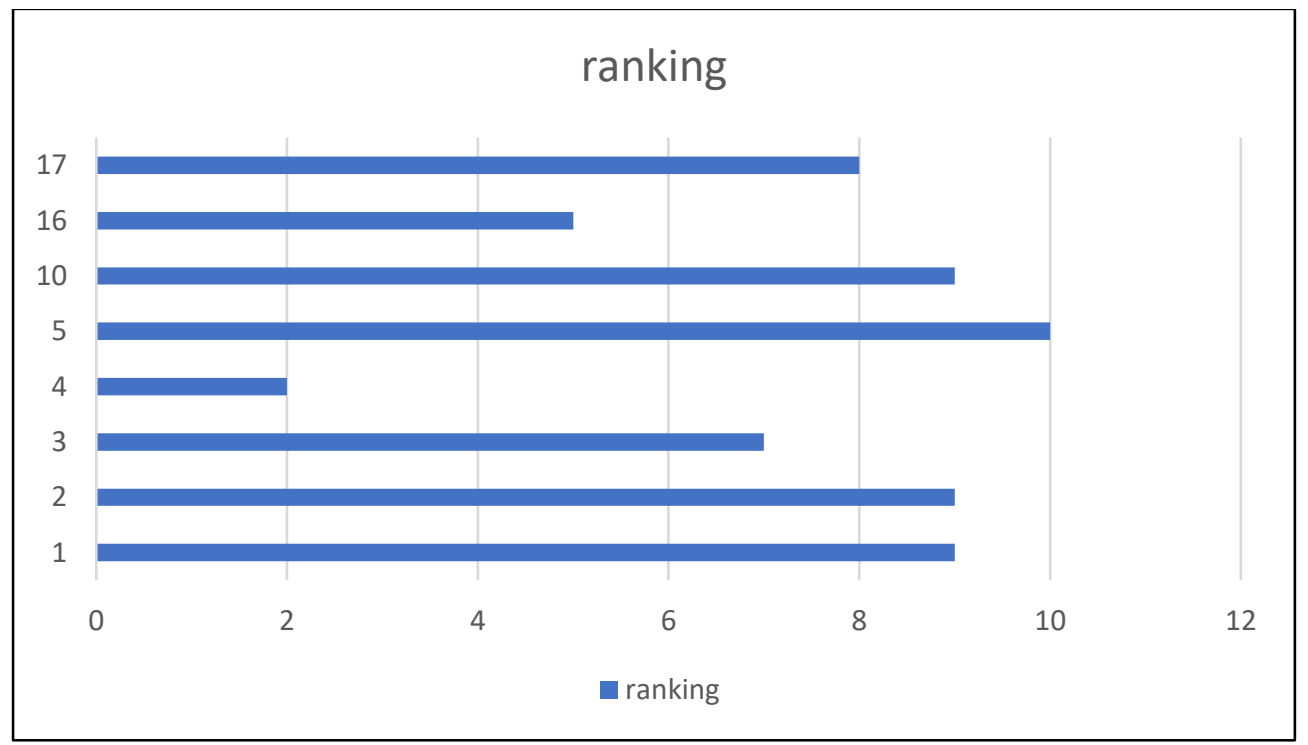

Figure 15: Irish rankings on SPI in 2020.

Source: SPI report 2020

In Figure 15 the numbers in the rows represent the social goals of UN in sustainability, while the columns sign the place of Ireland in SPI ranking. As it can be seen, Ireland belongs 
to the middle group of the developed EU member-states. This performance could be explained in partially with the lack of history in regarding the institutions with sustainability goals and infrastructural capacities.

\section{Findings - How and to what extent the sustainable competitiveness and the sustainable progress is correlating}

\subsection{Findings in general}

The parallel of competitiveness and social sustainability is assumed with strong reason. It seems that both of them stand on the same social indicators at first glance. The more developed social indicators mean the more sustainable society by definition. However, the results and rankings of Ireland on GCI, GSCI and SPI show much less correlation than it was assumed. In order to find the currently hidden causes of the lack of the parallel should be investigated with deeper statistical analysis. Although, it has to be emphasized that instead of competitiveness index covers numerous factors of sustainability, also contains conditions and consequences which directly and indirectly, but hurt deeply the environmental and even certain social goals of sustainability efforts. Albeit the strong intentions to make a complex measuring tool for sustainability in economic terms as well, it seems that neither of the currently available indices is able to forecast or even measure the reality.

Ireland's economic performance in competitiveness terms is proved by the GCI, while the sustainability perspective signs partially worth future perspective for the country. Also, the SGCI tends to overestimate certain sustainability indicators which can be easily compensated by advantages on other indicators.

\subsection{The Irish case}

In the case of Ireland, the social reform-based competitiveness is proved, while these indicators and required conditions of other types of sustainability seem to melt into the environmental sustainability conditions of SGCI. Based on the implemented indices, Ireland stays in a good position globally as placing in the first and top countries of the world.

Obviously, Ireland bears crucial environmental and social challenges, but currently it seems that the country can countervail these issues by its economic success. Like in other cases of successful small states, the social conditions show extreme positions and numbers regarding the sub-pillars and special social relating indicators of the indices. This means that the deep and long-term social policy reforms, based on the requirements of the current and assumed future definition of competitiveness are one of an effective way of becoming competitive and 
sustainable in the $21^{\text {st }}$ century. As the GSCI puts Ireland to the top 15 with the strong focus on sustainability perspective, and the GCI ranking of the country is also stable globally in the top 30., suggests that the Irish economic miracle is sustainable and socially founded. This conclusion is ensured also by the lack of the correlation between the two indices' lists. Within two different data set and analysis methodology Ireland performed in a good place. Regarding the SPI ranking, as the global rankings illustrate, the majority of the developed EU memberstates take top places in the world. Meaning that being average among the goods means a good position globally as well.

Another crucial conclusion of the Irish case is that path-dependency circle can be broken through fundamental social policy reforms, in parallel with similarly basic strategic change in national economy. As all the sustainability debate emphasizes, the harmonised actions of different policy fields mean the long-term solution of being sustainable in any terms.

\section{Conclusion}

As the challenge is noticed on many forums, the conditions of competitiveness, economic success and the indicators of social sustainability collide in many points. These tensions between the two basic and typical policy-making goals of national governments have to be harmonized and moreover, have to be calculated within the global indicators (global environmental footprint of the Scandinavian oil industries, global supply chains etc.). Without the harmonization of these different goals, the declared sustainability goals are only empty promises and unreal visions. Also, because the most competitiveness part and countries of the world are firstly competitive and by the way sustainable - seemingly-, if their interest let them happen. If sustainability is the first motivation of policy making, the whole global economic system and the policy-making strategies have to be re-designed.

The implied indices of competitiveness show the two ends of the sustainable economic performance scale. While the GCI tend to focus mostly on the pure economic conditions of competitiveness, the GSCI data set is built up on sustainability indicators in majority. Though, both of them measure competitiveness and try to catch the essence of the main conditions of economic success, their results differ significantly. While this phenomenon needs more statistical analysis and proof, in the Irish case it means good news for the country. Despite the endogen duplications of indicators and other questionable methodological details of the indices, Ireland's performance in social basis of economic and social sustainability can be valued in a high level. 
Based on the indices and the analysed indicators, if a country is sustainably competitive, then it is most likely socially sustainable. But this correlation seems really weak and false from many perspectives. As the controversies of the three main sustainability pillars show, the whole sustainability mission can hardly occur totally, only in partial. (DESPOTOVIC et al. 2016)

Sustainability is a complex and difficult topic; however, it determines the future of our world. No doubt that we cannot deal with it enough, but the scientific and policy-making approaches must become more realistic and less western-oriented considering values of competitiveness and meaning of sustainability in any terms.

\section{References}

BATTEL, R. N. M. 2003: Ireland's “Celtic Tiger” Economy. Science, Technology and Human Values, Vol. 28. Issue 1., pp. 93-111.

BOSTRÖM, M. 2012: A missing pillar? Challenges in theorizing and practicing social sustainability: introduction to the special issue. Sustainability: Science, Practice and Policy online journal. 8:1, pp. 3-14.

BOYER, R. H. W. - PETERSON, N. D. - ARORA, P. - CALDWELL, K. 2016: Five Approaches to Social Sustainability and an Integrated Way Forward. Sustainability. 2016, 8, p. 878.

CALHOUN, C. - DERLUGUIAN, G. (eds.) 2011: Aftermath. A New Global Economic Order? New York University Press.

COLEMAN, J. 1994: Social Capital in the Creation of Human Capital. American Journal of Sociology. 94:S 95-S120; University of Chicago Press.

CUTHILL, M 2009: Strengthening the social in sustainable development: developing conceptual framework for social sustainability in a rapid urban growth region Australia. Sustainable Development 18(6) pp. 362-373.

DEMPSEY, N. - BRAMLEY, G. - POWER, S. - BROWN, C. 2011: The social dimension of sustainable development: Defining urban social sustainability. Sustainable Development, 19(5), pp. 289-300.

DESPOTOVIĆ, D. - CVETANOVIĆ, S. - NEDIĆ, V. 2016: Analysis of innovativeness, as a determinant of competitiveness of the selected European countries. Industrija 44(1), pp. 89-111.

EU POLICY DEPARTMENT FOR ECONOMIC, SCIENTIFIC AND QUALITY OF LIFE POLICIES DIRECTORATE - GENERAL FOR INTERNAL POLICIES. 2020: Social Sustainability. Concepts and Benchmarks. 2020. April. Retrieved from: 
https://www.europarl.europa.eu/RegData/etudes/STUD/2020/648782/IPOL_STU(2020)6 48782_EN.pdf Accessed: 04.19.2021.

FOLADORI, G. 2005: Advances ad Limits of Social Sustainability as an Evolving Concept. Canadian Journal of Development Studies/Revue Canadienne d'études Du Dévéloppement, 2683, pp. 501-510.

GRIESSLER, E. - LITTIG, B. 2005: Social sustainability: a catchword between political pragmatism and social theory. Sustainable Development. Vol. 8. Nos. 1/2., 2005. pp. 65-79.

HALE, J. - LEGUN, K. - CAMPBELL, H. - CAROLAN, M. 2019: Social sustainability indicators as performance. Geoforum 103. pp. 47-55.

HOPWOOD, B. - MELlOR, M. - O’BRIEN, G. 2005: Sustainable Development: Mapping Different Approaches, Sustainable Development 13, pp. 38-52.

IRISH DEPARTMENT OF FOREIGN AFFAIRS AND TRADE. 2015: Global Irish. Ireland's Diaspora Policy. Retrieved from: https://www.dfa.ie/media/globalirish/global-irishirelands-diaspora-policy.pdf Accessed: 03.06.2021.

IRISH NATIONAL ECONOMIC AND SOCIAL COUNCIL. 1981: Irish Social Policies Priorities for Future Development. Retrieved from: https://www.nesc.ie/publications/irishsocial-policies-priorities-for-future-development/ Accessed: 03.11.2021.

JOHNSTON, R. - RUANE, F. - HEERY, L. 2019: Competitiveness on the Island of Ireland. Journal of the Statistical and Social Inquiry Society of Ireland, Vol. XLVIII. pp. 175-194.

KAHN, M. 1995: Concepts, definitions, and key issues in sustainable development: The outlook for the future. Proceedings of the 1995 International Sustainable Development Research Conference. Manchester, England, 27/28. March. Keynote paper, pp. 2-13.

KELLEY, A.C. 1991: The human development index: 'handle with care'. Population and Development Review 17, pp. 315-324.

KETSCHAU, T.J. 2017: Social sustainable development or sustainable social developmentTwo sides of the same coin? The structure of social justice as a normative basis for social dimension of sustainability. International Journal of Design and Nature and Ecodynamics, 12(3), pp. 338-347.

MARCUSE, P. 1998: Sustainability is not enough. Environment and Urbanization 10(2) pp. 103-111.

MURPHY, E. C. - OESCH, D. 2018: Is Employment Polarisation Inevitable? Occupational Change in Ireland and Switzerland, 1970-2010. Work, Employment and Society 2018, Vol. 32(6) pp. 1099-1117. 
MURPHY, K. 2012: The social pillar of sustainable development: a literature review and framework for policy analysis. Sustainability: Science, Practice and Policy online journal. 8:1, pp. 15-29.

NEUMAYER, E. 2001: The human development index and sustainability - a constructive proposal. Ecological Economics-39. 2001. pp.101-114.

NEUMAYER, E. 2010: Human Development and Sustainability January. Journal of Human Development and Capabilities 13(HDRP-2010-05) pp. 561-579.

O'CONNOR, M. 2014: Investment in edification: reflections on Irish education policy since independence. Irish Educational Studies. Volume 33, 2014 - Issue 2: Investment in Education and the intractability of inequality. pp. 193-212.

POPESCU G. H. - SIMA V. - NICA E. - GHEORGHE I. G. 2017: Measuring Sustainable Competitiveness in Contemporary Economies - Insights from European Economy. Sustainability. 2017. 9. p. 1230.

POWER, C. - CONFEDERATION OF IRISH INDUSTRY 1980: White Paper on Educational Development.

RAVALLION, M. 1997: Good and bad growth: The human development reports. World Development. Volume 25, Issue 5, May 1997, pp. 631-638.

SACHS, I. 1999: Social Sustainability and whole development. Exploring the dimensions of sustainable development. In E.B. - T. Jahn (eds.): Sustainability and the social science: A Cross-Disciplinary Approach to integrating Environmental Consideration into Theoretical Reorientation, pp. 25-36.

SCHWAB, K. - WORLD ECONOMIC FORUM 2011-2020: Global Competitiveness Index Report. Retrieved from: https://www.weforum.org/reports Accessed: 03.20.2021.

SEN, A. - ANAND, S. 1994: Human Development Index: Methodology and Measurement. Paper written in preparation for the 1994 Human Development Report.

SOCIAL JUSTICE IRELAND. 2020: Sustainable Progress Index Retrieved from: https://www.socialjustice.ie/content/publications/sustainable-progress-index-2020. Accessed: 04.26.2021.

SOLABILITY. 2013-2020: Global Sustainable Competitiveness Index Report 2013-2020. Retrieved from: https://solability.com/the-global-sustainable-competitiveness-index/theindex Accessed: 04.05.2021.

THORE, S. - TARVERDYAN, R. 2016: The sustainable competitiveness of nations. Technological Forecasting and Social Change. Volume 106, May 2016, pp. 108-114. 
UM, J. - HAN, N. 2021: Understanding the relationships between global supply chain risk and supply chain resilience: the role of mitigating strategies, Supply Chain Management, Vol. 26 No. 2, pp. 240-255.

UNITED NATIONS. 2016-2021: The Sustainable Development Goals Report. Retrieved from: Accessed: 03.30.2021. 


\title{
Analysis of the youth labor market in the EEU countries Bauyrzhan URAZYMBETOV ${ }^{74}$
}

\begin{abstract}
One of the goals of the Treaty on the Eurasian Economic Union (EEU) from 05/29/2014 "The desire to form a single market for goods, services, capital and labor resources within the EEU" provides in the future significant opportunities to meet the needs of young people in the common labor market. The relevance of the topic is determined by the fact that the high level of youth unemployment and the growth of passive human capital is a macroeconomic problem in many countries, including the EEU countries. In this work, the following research methods were used: universal, general scientific, private, causal, systemic and structural, as well as economic, statistical and comparative analysis. The article discusses the results of research and analysis of the main indicators of the labor market of youth (from 15 to 29 years old) in the EEU countries for the period 2015-2019 years. A comparative analysis of the level of unemployment and education of youth, employment by industry. The main problems are identified and systematized labor market in the EEU: an increase in the category of youth NEET (Not in Education, Employment, or Training), inconsistency in vocational and qualification skills of graduates with the demands of the labor market, informal employment of young people and emigration of highly skilled frames. The main programs that contribute to the formation of youth in the labor market within the framework of Eurasian integration. Conclusions are drawn regarding measures which could improve the situation in the general youth labor market.
\end{abstract}

Keywords: labor market, EEU, employment, youth unemployment, youth NEET.

\section{Introduction}

Since 2015, the Eurasian Economic Union began to function. The participating countries today include the Russian Federation, Belarus, Kyrgyzstan, Kazakhstan and Armenia. The EEU, as the youngest integration association, from the very beginning took an active position in the implementation of sustainable development goals. For sustainable development is based on mutually reinforcing links between economic growth, environmental protection and employment.

As one of the main goals of the formation of the EEU, the desire to form a single labor market aimed at strengthening and expanding interaction in various economic spheres was identified, which implies using the labor resources available to the Union for the benefit of realizing the economic potential of each EEU member state. Within the EEU, citizens can find employment without additional permits. This is an additional opportunity for employment, career development, business for young people. The progressive development of integration depends on young people, their academic and professional training, the ability of specialists to understand their colleagues from neighboring countries (SAMOKHINA, E. A. 2011).

The labor market is a fundamental element of the economy of any country. In the system of regional integration in the context of globalization, changes are taking place in the world of work. These are changes in the process of labor activity, in the organization of labor, in the

\footnotetext{
${ }^{74}$ Corvinus University of Budapest, Doctoral School of International Relations and Political Science, PhD Candidate,Bauyrzhan.urazymbetov@stud.uni-corvinus.hu
} 
structure of employment, etc. As a rule, changes entail the emergence of some difficulties that are more strongly reflected in the more vulnerable category of the labor market - youth. Young people with difficulties integrating into the world of work suffer throughout their lives from scarring effects that reduce their resilience and ability to survive in a dynamic and demanding labor market. The solution to the problems of youth employment and unemployment, which cannot be called new, largely depends on the formation of legal conditions in the sphere of the functioning of the common labor market within the EEU and the effectiveness of the employment policy. Building a sustainable future means empowering youth in employment. Thus, the Strategic Directions for the Development of Eurasian Economic Integration until 2025 (EEC. Eurasian Economic Commission. 2020: Strategic Directions For Developing Eurasian Economic Integration Until 2025) laid down measures for the sustainable and inclusive development of each EEU member state, which also provide for increased employment and decent work for all social groups of the population.

The fundamental provision of the Treaty on the EEU is to provide labor migrants - citizens of the EEU countries with a national legal regime in the field of their labor rights. Restrictions of such a regime can be established only to ensure the highest national interests of the state.

\section{Integration aspects of the formation of a single labor market}

The Treaty on the Eurasian Economic Union of May 29, 2014 consolidated the rules that created conditions for the free movement of labor resources throughout the territory of the integration association. One of the fundamental freedoms of the single labor market is, in accordance with paragraph 1 . Article 98 of the Treaty on the EEU granting the right to engage in professional activities in accordance with the specialty and qualifications. This makes it possible for employers to involve workers of the EEU countries in the implementation of labor activities without taking into account the restrictions on the protection of the national labor market. Employees are not required to obtain a work permit in the country of employment. The EEU countries have concluded an agreement on the recognition of educational documents issued by educational organizations of the participating countries without carrying out the procedures for recognizing educational documents established by the legislation of the state of employment. In accordance with clause 2. Article 97, the exception is the sphere of activity related to the interests of national security.

A positive point for workers from the EEU member states is that the right to offset the length of service in the total length of service (insurance) for the purposes of social security 
(social insurance), in addition to pension, is an important aspect of the formation of a single labor market.

Despite the fact that in the EEU countries there are different pension systems, the issue of pension provision, the formation, preservation and implementation of workers' pension rights on the same conditions as citizens of the state of employment is settled in accordance with the Agreement on Pension Provision, signed by the heads of the EEU states on December 20, 2019 in St. Petersburg at a meeting of the Supreme Eurasian Economic Council. The agreement defines the procedure and mechanism for exporting pensions from one country of the Union to another, provides for the summation of the length of service in the EEU states to determine the right to a pension. In addition, the issue of medical examination of a worker, including an absentee medical examination when assigning a disability pension, has been resolved, and transitional provisions have been fixed that determine the procedure for the appointment and payment of pensions for periods of work before and after the entry into force of the Agreement.

The Treaty on the EEU provides for the taxation of income from employment of a migrant worker from one state of the Union on the territory of another member state at the tax rates provided for such income for residents of this state from the first day of their receipt. According to clause 2.3 of Article 98 of the Treaty on the EEU, a worker of a member state of the EEU has the right to an unhindered transfer of funds. In accordance with clause 6, clause 7 of Article 98 of the Treaty on the EEU, workers of the EEU member states are granted the right to receive information or documents (certificates) from the state bodies of the state of employment and / or the employer (customer of work (services)) regarding the procedure stay, conditions of employment, as well as other rights and obligations stipulated by the legislation of the state of employment.

Summarizing the norms of the Treaty on the EEU, we can conclude that the formation of a common labor market of the EEU countries is one of the most important factors in the economic recovery of the union states and an additional impetus to strive for sustainable development. The main directions of regulation of its labor market include: the fight against a further decline in production, prevention of mass unemployment, the adoption of measures to improve the standard of living of the population, etc.

\section{Analysis of the youth labor market in the EEU}

In 2019, the resident population of the EEU countries was about 184.3 million people (Figure 16). The economically active population was 93.6 million people. The able-bodied 
population of the EEU countries was about $70 \%$ of the total population, and the level of general unemployment was at 4.8\% (EEC documents, 2016, 2017, 2018, 2019, 2020).

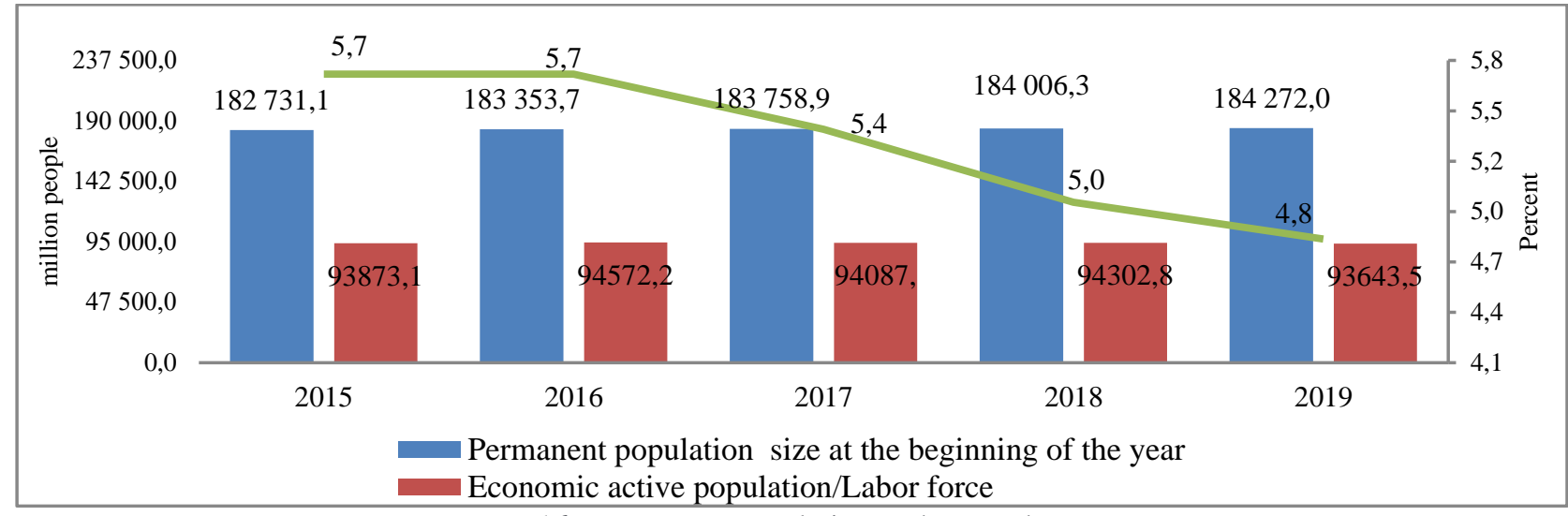

Figure 16: Permanent population and unemployment rate of the EEU countries

Source: Edition of the author based on the data of EEC. Eurasian Economic Commission. 2020: Statistical YEARBOOK of The Eurasian Economic Union. Moscow. p. 445.

Modern youth of the $21^{\text {st }}$ century in the context of globalization is very different from the previous generation in other landmarks and value orientations, characteristic of rational economic behavior. There is no universally accepted international definition of the age group of young people. However, for statistical purposes of the United Nations, according to the international definition, young people are considered to be persons aged 15 to 24 years, in the countries of the Eurasian Economic Union, people whose age ranges lie in the range from 15 to 29 years old are referred to as youth (EMPLOYMENT 2015: Analysis of The Youth Labor Market: A Package of Educational and Informational Materials on The Youth Labor Market $\mathrm{p}$ 147. ). And this is largely determined by ethnic characteristics, national traditions, characteristics of social status and socio-psychological qualities of people in this age group.

According to United Nations information, today there are about 1.2 billion young people living in the world, which is $16 \%$ of the world population. According to the Department of Statistics of the Eurasian Economic Commission (EEC), the number of youths in the EEU countries in 2019 was 31.9 thousand people, or $17.3 \%$ of the total population (Table 11). Most of the young population of the EEU lives in Russia (76.2\%), followed by Kazakhstan (12.2\%), Kyrgyzstan (5.0\%), Belarus (4.8\%) and Armenia (1.8\%) (EEC 2020).

At the same time, it is necessary to note the downward trend in youth growth rates in the EEU countries. So, from 2015 to 2019, the number of young people of the Union aged 15 to 29 years decreased by 5.4 thousand people. Moreover, this trend is observed in all EEU countries. In Armenia, the share of young people decreased over the period under review from $22.9 \%$ in 2015 to $19.5 \%$ in 2019; in Belarus - from 19.8\% to 16.0\%; in Kazakhstan - from $24.6 \%$ to 
$21.2 \%$; in Kyrgyzstan - from $28.3 \%$ to $25.2 \%$; in Russia - from $19.7 \%$ to $16.5 \%$, respectively. The definition of the dominant part of the youth labor market within the EEU was influenced by the indicator of migration growth (outflow (EEC documents, 2016, 2017, 2018, 2019, 2020)

\begin{tabular}{|c|c|c|c|c|c|c|c|}
\hline Years & Indicators & Armenia & Belarus & Kazakhstan & Kyrgyzstan & Russia & EEU \\
\hline \multirow{2}{*}{2015} & $\begin{array}{c}\text { Number of young } \\
\text { people, thousand people }\end{array}$ & 690 & 1873 & 4287 & 1671 & 28742 & 37263 \\
\cline { 2 - 8 } & $\begin{array}{c}\text { in \% of the total } \\
\text { population }\end{array}$ & 22,9 & 19,8 & 24,6 & 28,3 & 19,7 & 20,5 \\
\hline $\begin{array}{c}\text { Number of young } \\
\text { people, thousand people }\end{array}$ & 656 & 1814 & 4182 & 1663 & 27588 & 35903 \\
\cline { 2 - 8 } & $\begin{array}{c}\text { in \% of the total } \\
\text { population }\end{array}$ & 21,9 & 19,1 & 23,7 & 27,6 & 18,8 & 19,6 \\
\hline $\begin{array}{c}\text { Number of young } \\
\text { people, thousand people }\end{array}$ & 626 & 1745 & 4092 & 1644 & 26397 & 34504 \\
\hline $\begin{array}{c}\text { in \% of the total } \\
\text { population }\end{array}$ & 21,0 & 18,4 & 22,8 & 26,8 & 18,0 & 18,8 \\
\hline \multirow{2}{*}{2018} & $\begin{array}{c}\text { Number of young } \\
\text { people, thousand people }\end{array}$ & 601 & 1680 & 3990 & 1624 & 25272 & 33167 \\
\cline { 2 - 8 } & $\begin{array}{c}\text { in \% of the total } \\
\text { population }\end{array}$ & 20,2 & 17,7 & 22,0 & 26,0 & 17,2 & 18,0 \\
\hline $\begin{array}{c}\text { Number of young } \\
\text { people, thousand people } \\
\text { in \% of the total } \\
\text { population }\end{array}$ & 578 & 1520 & 3893 & 1608 & 24283 & 31882 \\
\hline
\end{tabular}

Table 11: Number of young people (15-29 years old) in the EEU countries

Source: Edition of the author based on the data of FEDERAL STATE STATISTICS SERVICE OF THE RUSSIAN FEDERATION 2019: The Demographic Yearbook of Russia. Statistical Handbook. Rosstat. p. 252. Retrieved from: https://www.gks.ru/bgd/regl/B19_16/Main.htm (downloaded 24. 02. 2021).

Today, only Russia and Belarus have a positive migration balance. Statistics on the increase in the flow of labor migration from the EEU member states to Russia: in 2019, 701.2 thousand people arrived in the Russian Federation, including 230.5 thousand people from the EEU countries. In 2015-2019, 904.8 thousand people arrived in Russia from other EEU countries (EEC documents, 2016, 2017, 2018, 2019, 2020).

According to the official data of the EEC Department of Statistics, the flow of workers attracted to the economy of the EEU member states from other countries in 2019 grew by $29.0 \%$ in Belarus compared to 2018 and amounted to 20.9 thousand people, in Russia - by 1,4\% (1,793.7 thousand people) and in Kazakhstan decreased by 1.0\% (25.9 thousand people) (EEC. 
Eurasian Economic Commission. 11/30/2020: On the Labor Market in The Eurasian Economic Union 2019. Analytical Review. ). Compared to 2015, in 2019 the flow of workers attracted to the economy of the EEU member states from other countries in Belarus decreased by $34 \%$, in Kazakhstan - by 31.7\%, in Russia - by 4\% (Table 12) (EEC documents, 2016, 2020).

\begin{tabular}{|c|c|c|c|c|c|}
\hline & 2015 & 2016 & 2017 & 2018 & 2019 \\
\hline Armenia & $\ldots$ & $\ldots$ & $\ldots$ & $\ldots$ & $\ldots$ \\
\hline Belarus & 31,8 & 20,8 & 15,8 & 16,2 & 20,9 \\
\hline Kazakhstan & 37,9 & 39,8 & 28,1 & 26,2 & 25,9 \\
\hline Kyrgyzstan & $\ldots$ & $\ldots$ & $\ldots$ & $\ldots$ & $\ldots$ \\
\hline Russia & 1868,6 & 1686,3 & 1773,9 & 1768,6 & 1793,7 \\
\hline
\end{tabular}

Table 12: The number of employees attracted to the economy from other countries (according to the migration services; thousand people).

Source: Edition of the author based on the data of EEC documents, 2016, 2017, 2018, 2019, 2020.

According to the Department of Statistics of the Eurasian Economic Commission for the period from 2015 to 2019 the number of persons who emigrated from Armenia abroad and registered with the internal affairs bodies upon changing their permanent place of residence was 14,767 (an increase of 3.5\% in 2019 compared to 2015) (Table 13). The number of people who immigrated to Armenia is 16,260 (an increase of 2.2 times in 2019 compared to 2015). However, according to the assessment of the results of the Integrated Survey of Living Conditions of Households in Armenia, there is a significant negative balance of international migration (- 108.3 thousand people).

\begin{tabular}{|l|c|c|c|c|c|}
\hline & 2015 & 2016 & 2017 & 2018 & 2019 \\
\hline Armenia & -881 & -93 & 286 & 480 & 1701 \\
\hline Armenia* & -25906 & -24792 & -23962 & -18286 & -15400 \\
\hline Belarus & 18494 & 7940 & 3874 & 9362 & 13870 \\
\hline Kazakhstan & -13466 & -21145 & -22130 & -29121 & -32970 \\
\hline Kyrgyzstan & -4229 & -3965 & -3925 & -5390 & -6160 \\
\hline Russia & 245384 & 261948 & 211878 & 124854 & 285103 \\
\hline EEU & 219396 & 219893 & 166021 & 81899 & 246144 \\
\hline *Assessment based on the results of the Integrated Survey of Living Conditions of Households \\
\hline
\end{tabular}

Table 13: Net migration of young people in the EEU countries (persons)

Source: Edition of the author based on the data of EEC. Eurasian Economic Commission. 2020:

Statistical Yearbook of The Eurasian Economic Union. Moscow. p. 445. 
In 2015-2019, the negative balance of the migration outflow of the population from Kazakhstan amounted to about 119 thousand people, from Kyrgyzstan about 24 thousand people. The resulting negative migration balance indicates an increase in the outflow of labor resources, creates a shortage of qualified personnel in the donor country.

The competitiveness of young people in the labor market largely depends on the level of education. High-quality education provides an opportunity for self-realization of young people, increases labor productivity, promotes career growth, material well-being and a healthy lifestyle. In terms of education, a significant part of the employed youth of the EEU countries have higher education. So, according to the national statistical services, in 2019 in Armenia $51.9 \%$ of employed young people aged 25-29 had higher professional education to the total number of employed young people of the corresponding age, in Kazakhstan - 46.7\%, in Belarus - $44.1 \%$, in Russia - 41.1\% (EEC. Eurasian Economic Commission. 11/30/2020: On the Labor Market in The Eurasian Economic Union 2019. Analytical Review. ).

In Kyrgyzstan, as a result of an integrated sample survey of household budgets and labor force in 2019, organized by the National Statistical Committee of the Kyrgyz Republic, it was recorded that $27.6 \%$ of employed youth aged 25-29 had a higher professional education, and $7.1 \%$ had a secondary vocational education, primary vocational education $-8.0 \%$ and $46.2 \%$ of employed young people had only secondary (complete) education (NATIONAL STATISTICAL COMMITTEE OF THE KYRGYZ REPUBLIC 2020: Employment and Unemployment. Results of The Integrated Sample Survey of Household Budgets and Labor Force In 2019. ). This is due to the fact that the labor market in Kyrgyzstan is not economically and socially stable. In addition to unemployment, an acute problem in the republic is a parallel shortage of skilled labor. The supply of labor exceeds the demand for it and for one job, there are 17 people for one declared vacancy in the state employment service, and it is not possible to provide jobs for all those who applied to the employment service (EUROPEAN Foundation for Education. 2020: Kyrgyzstan National Report/ Turin Process 2018-2020. p 41. ). Despite the fact that the youth of the EEU countries is characterized by a high degree of learning ability, they still do not have the necessary professional skills to compete in the skilled labor market. As practice shows, it is young people who are more affected by informal labor relations.

In the EEU countries, informal employment has become widespread during the period of socio-economic transformations; since the beginning of the 90s, its active growth has been observed, directly related to the level of socio-economic development of countries and with limited employment opportunities in the real sector. The development of the informal sector is 
a forced reaction of young people to the socio-economic situation, which forced people to adapt to new economic conditions. Globally, the share of the informal sector of the economy is estimated at 5-10\% of GDP, its marginal threshold is $45-50 \%$, but this is rather rough data, since it is necessary to determine the scale of shadow employment and the number of those employed in the formal sector with additional informal employment. Unfortunately, informal employment does not lend itself to accurate statistics and therefore affects the distortion of data on the real state of the labor market and employment. Currently, informal employment has become an independent and stable segment of the labor market. It allows employees to carry out labor activities without legal registration of labor relations and is reflected in the efficiency of the use of labor, the quality of working life of the population. To analyze the youth labor market, we present the official data of the national statistical services of the EEU member states.

Thus, in Armenia, the share of informal employment in non-agricultural sectors in 2018 amounted to $20.8 \%$ of total employment in non-agricultural sectors. According to the Committee on Statistics of the Republic of Kazakhstan, the level of youth employment in the informal sector decreased by $9.3 \%$ and amounted to 13.7\% in 2019 (COMMITTEE on STATISTICS OF THE REPUBLIC OF KAZAKHSTAN. 2020: Indicators of Decent Work of The Republic of Kazakhstan). In 2019, 532 thousand young people worked informally in Kyrgyzstan, including in the age groups: 18-24 years old - 259.4 thousand people, 25-29 years old - 240.5 thousand people (NATIONAL STATISTICAL COMMITTEE OF THE KYRGYZ REPUBLIC 2020: Employment and Unemployment. Results of The Integrated Sample Survey of Household Budgets and Labor Force In 2019. ). In Russia, according to Rosstat, in 2019, 3110 thousand people aged 15-29 worked in the informal sector of the economy, including 168 thousand people aged 15-19 years old, 2,942 thousand people aged 20-29 years old. The level of informal employment of the population of Belarus was 8.0\% in 2019, and in 2018 8.2\% of the total employment in non-agricultural sectors (NATIONAL STATISTICAL COMMITTEE OF THE REPUBLIC OF BELARUS. 2020: Indicators for Achieving Sustainable Development in The Republic of Belarus 2020).

Among the most common reasons for difficulties in finding a job for graduates are: lack of demand for a profession, lack of seniority (experience) of work, insufficient wages, lack of vacancies. The main reasons for youth unemployment are indicated: lack of work after graduation, dismissal due to liquidation (bankruptcy) of the organization, staff reductions, dismissal due to the expiration of the term of the agreement (agreement, contract).

Overcoming unemployment is one of the important socio-economic problems of the EEU countries. Thanks to the implementation of national programs to stabilize the situation on the 
labor market, according to the official statistics of the EEC, in 2019 the number of unemployed in the Union among young people aged 15-24 decreased to 900.5 thousand people, while in 2017 their number exceeded 1057 thousand people (Table 14). In parallel, there was a gradual decrease in the share of the number of unemployed youth in the total number of unemployed.

In all EEU countries in 2019, with the exception of Kazakhstan, the unemployment rate among young people aged 15-24 was higher than the national average. The problem of unemployment among young people in Armenia is especially critical today. According to the official statistics of the EEC, in the period under review in Armenia, the unemployment rate among young people aged 15-29 reaches more than 52\%. According to the methodology of the International Labor Organization, the peak of growth in the level of unemployment among young people for the period under review was in Armenia in 2017, Belarus in 2016 and 2018, Kazakhstan in 2015, Kyrgyzstan in 2016, Russia in 2018 (Figure 17 and Figure 18) (EEC 2020).

\begin{tabular}{|c|c|c|c|c|c|c|c|c|c|c|}
\hline & \multicolumn{2}{|c|}{2015} & \multicolumn{2}{|c|}{2016} & \multicolumn{2}{|c|}{2017} & \multicolumn{2}{|c|}{2018} & \multicolumn{2}{|c|}{2019} \\
\hline & 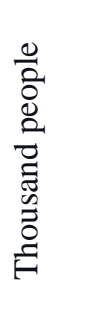 & 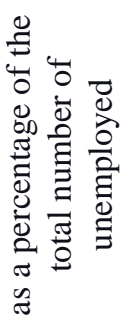 & 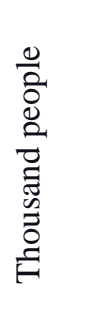 & 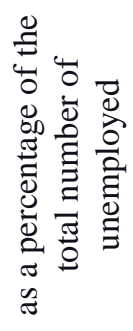 & 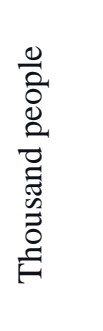 & 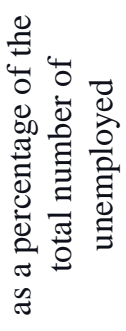 & 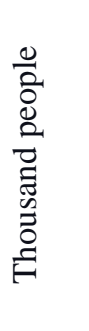 & 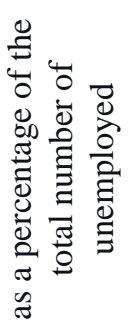 & 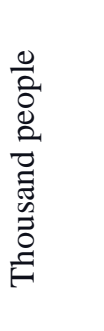 & 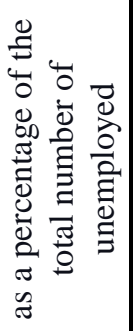 \\
\hline Armenia & 52,4 & 21,5 & 45,8 & 20,8 & 46,7 & 21,3 & 45,5 & 18,5 & 43,0 & 17,9 \\
\hline Belarus & $\ldots$ & $\ldots$ & 53,9 & 17,9 & 47,4 & 16,1 & 47,3 & 19,3 & 43,0 & 20,2 \\
\hline Kazakhstan & 53,8 & 11,9 & 44,1 & 9,9 & 38,6 & 8,7 & 37,0 & 8,3 & 39,0 & 8,9 \\
\hline Kyrgyzstan & 71,0 & 36,9 & 69,7 & 37,9 & 61,9 & 35,6 & 51,6 & 33,0 & 49,4 & 35,0 \\
\hline Russia & 1041,2 & 24,4 & 989,5 & 23,3 & 862,8 & 21,8 & 818,5 & 22,4 & 726,1 & 21,0 \\
\hline
\end{tabular}

Table 14: The number of unemployed persons between the ages of 15 and 24 (according to the ILO criteria). Source: Edition of the author based on the data of Committee on Statistics of The Republic of Kazakhstan. 2020: Employment FEDERAL STATE STATISTICS SERVICE OF THE RUSSIAN FEDERATION 2020: Labor Force, Employment and Unemployment in Russia (Based on The Results of Sample Labor Force Surveys). Statistical Collection. Rosstat. p. 145. 


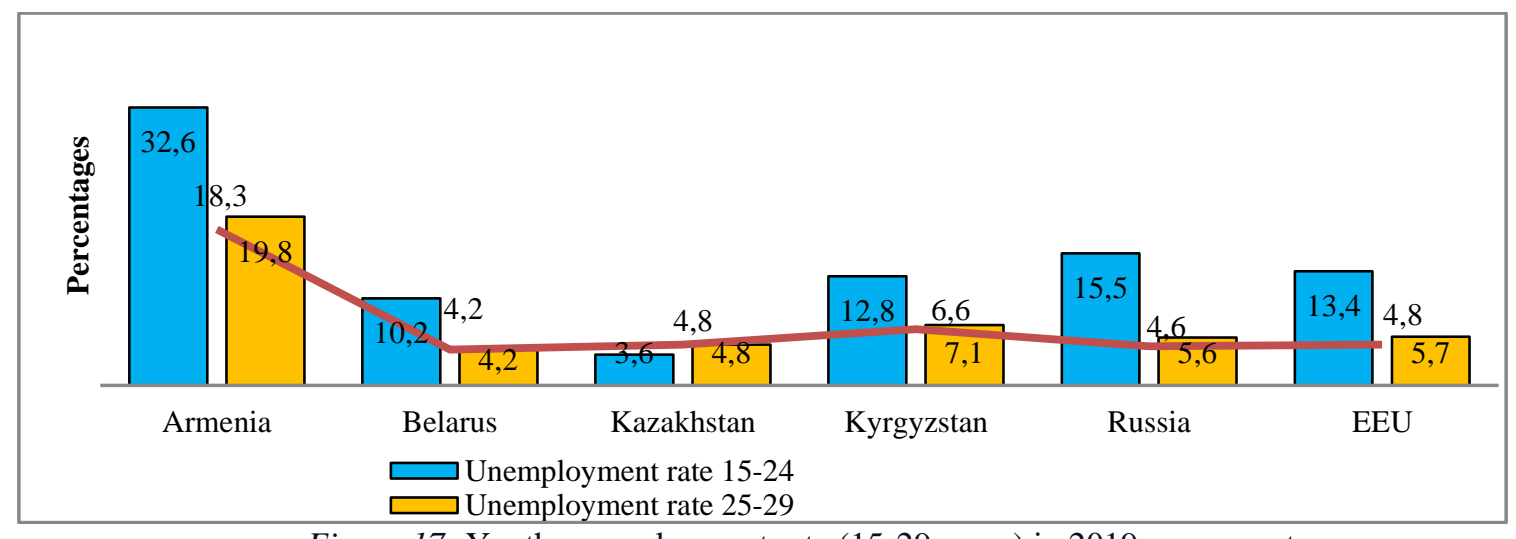

Figure 17: Youth unemployment rate (15-29 years) in 2019, as percentage

Source: Edition of the author based on the data of EEC. Eurasian Economic Commission. 11/30/2020: On the Labor Market in The Eurasian Economic Union 2019. Analytical Review.

Practically in all EEU member states in 2019, there was a positive downward trend in the level of youth unemployment compared to 2018, except for Kyrgyzstan: the unemployment rate among young people aged 15-24 increased by 0.4 percentage points. In 2019 alone, 6,721 people left Kyrgyzstan for the EEU countries from 2015 to 2019, more than 32.8 thousand citizens left.

For the period from 2015 to 2019, the level of youth unemployment in accordance with the ILO criteria in Kazakhstan decreased by $0.5 \%$ to $3.6 \%$, in Kyrgyzstan it decreased by $2.7 \%$, in Russia - by $0.5 \%$. In absolute terms, the number of unemployed youth from 2015 to 2019 in Kazakhstan decreased by 14.8 thousand people, in Kyrgyzstan - by 21.6 thousand people, in Russia - by 315.1 thousand people. In Armenia, on the contrary, the number of unemployed in 2019 increased by 9.4 thousand people compared to 2015 (Figure 18).

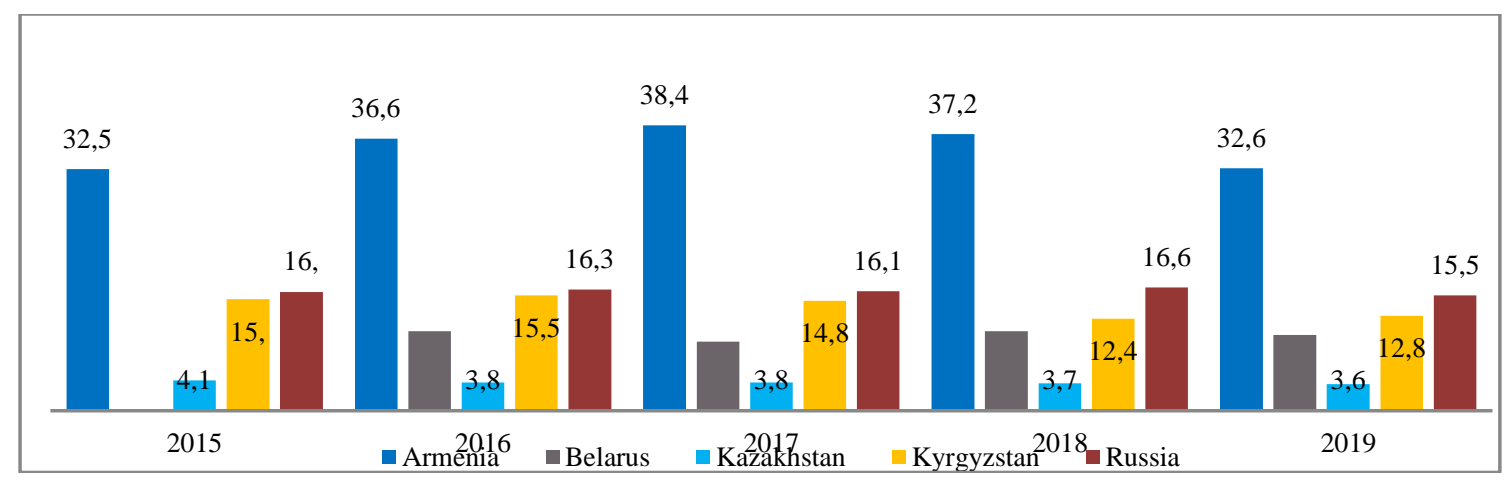

Figure 18: Youth unemployment rate between the ages of 15 and 24 (according to the ILO criteria) (as a percentage)

Source: Edition of the author based on the data of EEC documents, 2016, 2017, 2018, 2019, 2020.

In almost all EEU member states, according to the results of sample surveys of national statistical services in 2019, the highest level of youth unemployment is characteristic of young people aged 15 to 24 years with a general secondary education, and from 25 to 29 years old 
with vocational education (Table 15). The exceptions are Kazakhstan and Russia, where the share of unemployed persons aged 25 to 29 with higher professional education is much higher.

Most likely, this is due to the mismatch between supply and demand in the labor market for various professions, which in turn due to insufficient information about modern relevant specialties in various sectors of the economy. Moreover, the lack of an effective assessment and forecast of the required specialties leads to a discrepancy between the specialties produced and the modern needs of the labor market. For example, more than $66 \%$ of the population of the EEU countries is employed in the service sector; more than $19 \%$ are employed in agriculture, forestry and fisheries (Figure 19).

So, according to official statistics, the number of youth employed in the service sector of Kazakhstan aged 15-28 years in 2019 amounted to 5307.4 thousand people or $68.1 \%$.

In Kyrgyzstan, young people aged 15-29 are employed in the service sector 348.1 thousand people or $53.3 \%$ of the total number of employed people in accordance with age, in Belarus $-63.2 \%$, respectively.

Recently, the problem of a high level of NEET youth, youth who do not want to work or study, has become relevant for all EEU member states, which is explained by the degradation of youth values in the world of work, the predominance of material values in the perception of young people, high expectations, especially among people with higher education. According to the official data of the EEC, in 2018 Armenia is the leader in terms of NEET of youth $(35.8 \%$ percentage of the total youth) (Figure 20). The lowest rates in the same year were recorded in Kazakhstan (6.0\% percentage of the total youth) and Belarus $(6.3 \%$ percentage of the total youth). ${ }^{75}$

\footnotetext{
75 Note: Since 2018 the concepts of "Resolution concerning statistics of work, employment and labor underutilization were introduced, adopted by the 19th International Conference of Labor Statisticians (ACHEVING 2019).
} 


\begin{tabular}{|c|c|c|c|c|c|c|c|c|}
\hline \multirow[b]{2}{*}{$\begin{array}{l}\text { Age } \\
\text { group }\end{array}$} & \multirow[b]{2}{*}{ Total } & \multicolumn{7}{|c|}{ Including those who have an education: } \\
\hline & & Higher & $\begin{array}{l}\text { Incomplete } \\
\text { higher }\end{array}$ & $\begin{array}{l}\text { Medium } \\
\text { special }\end{array}$ & $\begin{array}{l}\text { Professional } \\
\text { and technical }\end{array}$ & $\begin{array}{l}\text { General } \\
\text { average }\end{array}$ & $\begin{array}{c}\text { General } \\
\text { initial }\end{array}$ & $\begin{array}{c}\text { Do not } \\
\text { have a } \\
\text { basic } \\
\text { common }\end{array}$ \\
\hline \multicolumn{9}{|c|}{ Belarus } \\
\hline $15-19$ & 100,0 & 0,0 & 0,0 & 15,1 & 8,6 & 56,3 & 20,0 & 0,0 \\
\hline $20-24$ & 100,0 & 19,5 & 0,0 & 21,2 & 24,5 & 34,0 & 0,8 & 0,0 \\
\hline $25-29$ & 100,0 & 24,8 & 0,0 & 19,2 & 33,7 & 20,4 & 1,9 & 0,0 \\
\hline \multicolumn{9}{|c|}{ Kazakhstan } \\
\hline $16-19$ & 100,0 & 0,0 & 0,0 & 48,3 & 6,9 & 31,0 & 13,8 & 0,0 \\
\hline $20-24$ & 100,0 & 32,1 & 7,0 & 42,2 & 3,1 & 14,8 & 0,8 & 0,0 \\
\hline $25-29$ & 100,0 & 44,8 & 1,6 & 38,0 & 2,5 & 12,4 & 0,5 & 0,2 \\
\hline \multicolumn{9}{|c|}{ Kyrgyzstan } \\
\hline $16-19$ & 100,0 & 0,0 & 0,0 & 0,0 & 0,0 & 12,5 & 78,1 & 9,4 \\
\hline $20-24$ & 100,0 & 17,1 & 1,7 & 27,1 & 2,8 & 41,0 & 10,3 & 0,0 \\
\hline $25-29$ & 100,0 & 39,3 & 3,4 & 5,6 & 5,6 & 39,7 & 6,0 & 0,4 \\
\hline \multicolumn{8}{|c|}{ Russia } & \\
\hline $15-19$ & 100,0 & 0,0 & 0,0 & 7,2 & 7,7 & 49,1 & 31,9 & 4,1 \\
\hline $20-24$ & 100,0 & 21,6 & 0,0 & 21,8 & 12,8 & 35,8 & 7,4 & 0,6 \\
\hline $25-29$ & 100,0 & 31,3 & 0,0 & 19,1 & 16,7 & 24,2 & 8,1 & 0,6 \\
\hline
\end{tabular}

Table 15: Structure of unemployed youth by education and age group in the EEU countries 2019 (according to sample surveys; as a percentage)

Source: Edition of the author based on the data of EEC documents, 2016, 2017, 2018, 2019, 2020. 


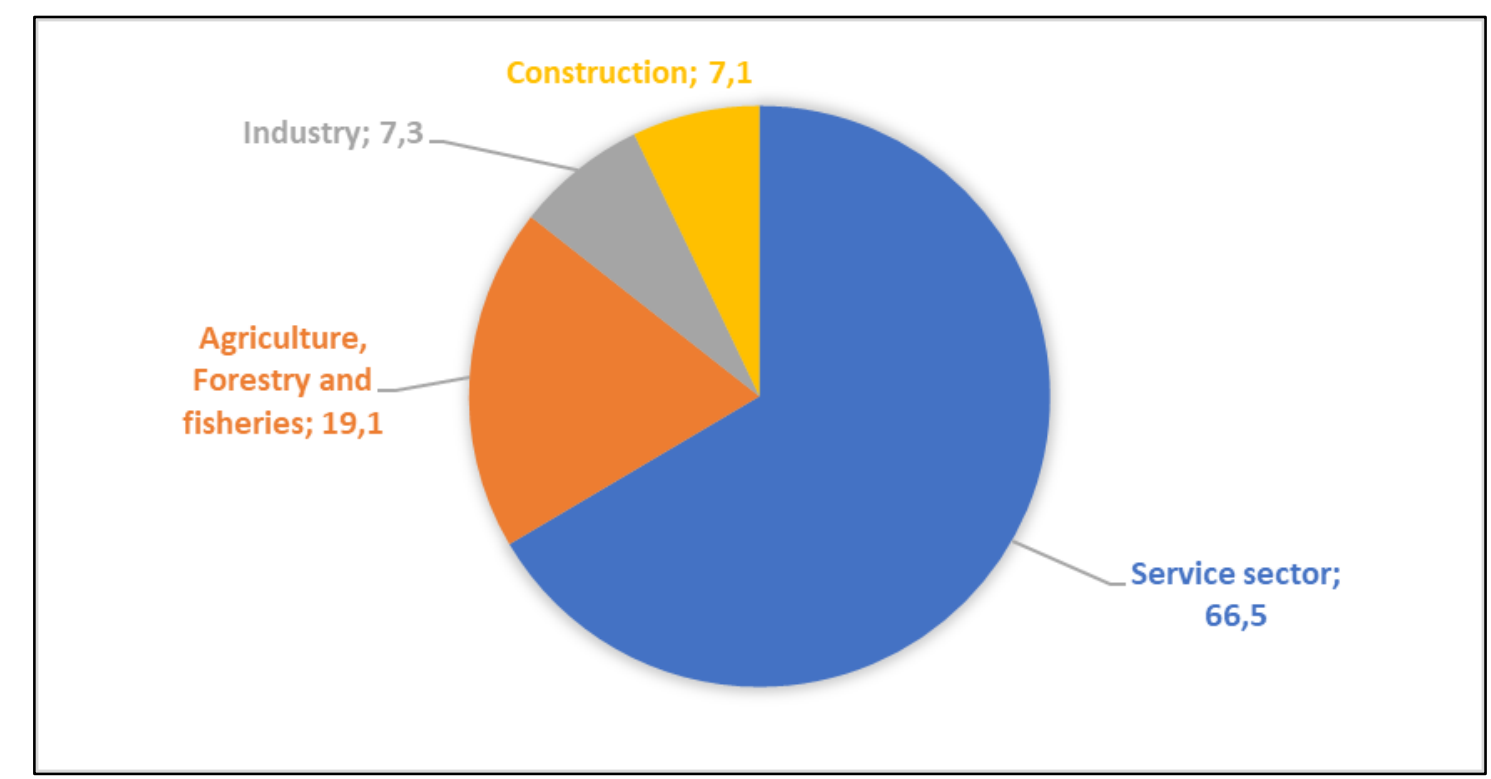

Figure 19: Distribution of the employed population as a whole in the EEU by field of activity in 2019 (as a percentage of the total)

Source: Edition of the author based on the data of EEC 2020

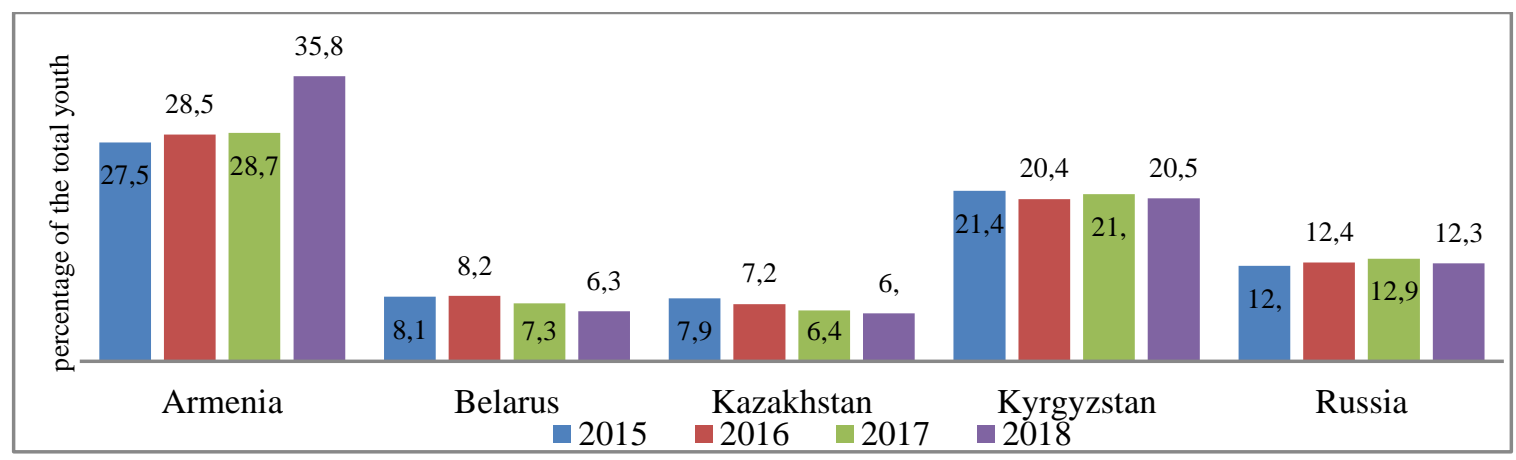

Figure 20: Proportion of youth (aged 15-24 years) not in education, employment and training (NEET) (percentage of the total youth)

Source: Edition of the author based on the data of EEC documents, 2016, 2017, 2018, 2019, 2020.

\section{Conclusion}

Summarizing the above analysis of the youth labor market in the EEU countries, the following conclusions can be drawn:

- Young people face two interrelated problems - sustainable development and their professional prospects;

- It is necessary to introduce professional programs, according to which highly qualified personnel can stay in the country for a longer period (for example, such programs are actively used in the USA, Canada, France, and Sweden); 
- Increasing the quality of the workforce, jobs, and specialties in demand through active interaction between educational institutions, the state and companies. Assistance in further employment of graduates of educational institutions;

- It is recommended to create a common information base on employment and vacancies in the EEU countries, reflecting the need for labor in each country, broken down by regions, industries and specialties, qualifications (in host countries), as well as labor supply (in countries of origin);

- Employment outside the specialty and unproductive self-employment of young people lead to a decrease in the level of human capital and losses of the state budget due to the "potentially lost" benefits from employment of young people and their payment of taxes

- Promotion of youth employment ensures sustainable development, which includes aspects such as employment policy formulation, safe working conditions, social protection, normal labor relations and human resource development strategies.

\section{References}

COMMITTEE ON STATISTICS OF THE REPUBLIC OF KAZAKHSTAN. 2020: Employment in Kazakhstan. Statistical Collection 2015-2019. Nur-Sultan. Retrieved from: https://stat.gov.kz/edition/publication/collection (downloaded: 24. 02. 2021).

COMMITTEE ON STATISTICS OF THE REPUBLIC OF KAZAKHSTAN. 2020: Indicators of Decent Work of The Republic of Kazakhstan. Nur-Sultan. Retrieved from: https://old.stat.gov.kz/faces/wcnav_externalId/homeNumbersLabor?_afrLoop=8208582 796345621\#\%40\%3F_afrLoop\%3D8208582796345621\%26_adf.ctrlstate\%3Dk9j4w44qv_38 (downloaded 24.02.2021).

EMPLOYMENT 2015: Analysis of The Youth Labor Market: A Package of Educational and Informational Materials on The Youth Labor Market - p 147. Policy Department. Moscow: Ilo. Retrieved from: https://www.ilo.org/wcmsp5/groups/public/---europe/--ro-geneva/---sro-moscow/documents/publication/wcms_425634.pdf (downloaded 24. 02. 2021).

EEC. Eurasian Economic Commission 10/31/2016: On the Labor Market in The Eurasian Economic Union 2015. Analytical Review. Retrieved from: http://www.eurasiancommission.org/ru/act/integr_i_makroec/dep_stat/econstat/Docume nts/labourmarket_2015.pdf (downloaded 24.02.2021).

EEC. Eurasian Economic Commission 10/30/2017: On the Labor Market in The Eurasian Economic Union 2016. Analytical Review. Retrieved from: 
http://www.eurasiancommission.org/ru/act/integr_i_makroec/dep_stat/econstat/Docume nts/labourmarket_2016.pdf (downloaded 24. 02. 2021).

EEC. Eurasian Economic Commission 10/30/2018: On the Labor Market in The Eurasian Economic Union 2017. Analytical Review. Retrieved from: http://www.eurasiancommission.org/ru/act/integr_i_makroec/dep_stat/econstat/Docume nts/labourmarket_2017.pdf (downloaded 24.02. 2021).

EEC. Eurasian Economic Commission. 10/30/2019: On the Labor Market in The Eurasian Economic Union 2018. Analytical Review. Retrieved from: http://www.eurasiancommission.org/ru/act/integr_i_makroec/dep_stat/econstat/Docume nts/labourmarket_2018.pdf (downloaded 24. 02. 2021).

EEC. Eurasian Economic Commission. 11/30/2020: On the Labor Market in The Eurasian Economic Union 2019. Analytical Review. Retrieved from: http://www.eurasiancommission.org/ru/act/integr_i_makroec/dep_stat/econstat/Docume nts/labourmarket_2019.pdf (downloaded 24.02.2021).

EEC. Eurasian Economic Commission. 2020: Statistical Yearbook of The Eurasian Economic Union. Moscow. $\quad$ p. 445. Retrieved from: http://www.eurasiancommission.org/ru/act/integr_i_makroec/dep_stat/econstat/Docume nts/Stat_Yearbook_2020.pdf (downloaded 24. 02. 2021).

EEC. Eurasian Economic Commission. 2020: Achieving the Sustainable Development Goals in the Eurasian Region economic community. Statistical booklet. - Moscow. p. 40. Retrieved from: http://www.eurasiancommission.org/ru/act/integr_i_makroec/dep_stat/econstat/Docume nts/SDG_booklet.pdf (downloaded 24. 02. 2021).

EEC. Eurasian Economic Commission. 2020: Strategic Directions For Developing Eurasian Economic Integration Until 2025. Retrieved from: https://Docs.Eaeunion.Org/Docs/RuRu/01228321/Err_12012021_12 (downloaded 26. 02. 2021).

EUROPEAN Foundation for Education. 2020: Kyrgyzstan National Report/ Turin Process 2018-2020. $\mathrm{p} \quad 41 . \quad$ Retrieved from: https://openspace.etf.europa.eu/sites/default/files/2020-

09/TRPreport_2020_Kyrgyzstan_EN.pdf. (downloaded 26.02.2021).

FEDERAL STATE STATISTICS SERVICE OF THE RUSSIAN FEDERATION 2020: Labor Force, Employment and Unemployment in Russia (Based on The Results of Sample Labor Force Surveys). Statistical Collection. Rosstat. p. 145. Retrieved from: https://gks.ru/bgd/regl/B20_61/Main.htm (downloaded 24. 02. 2021). 
FEDERAL STATE STATISTICS SERVICE OF THE RUSSIAN FEDERATION 2019: The Demographic Yearbook of Russia. Statistical Handbook. Rosstat. p. 252. Retrieved from: https://www.gks.ru/bgd/regl/B19_16/Main.htm (downloaded 24. 02. 2021).

NATIONAL STATISTICAL COMMITTEE OF THE KYRGYZ REPUBLIC 2020: Employment and Unemployment. Results of The Integrated Sample Survey of Household Budgets and Labor Force In 2019. Bishkek. Retrieved from: http://www.stat.kg/ru/publications/zanyatost-i-bezrabotica-itogi-integrirovannogovyborochnogo-obsledovaniya-byudzhetov-domashnih-hozyajstv-i-rabochej-sily-v2013g/ (downloaded 24. 02. 2021).

NATIONAL STATISTICAL COMMITTEE OF THE REPUBLIC OF BELARUS. 2020:

Indicators for Achieving Sustainable Development in The Republic of Belarus 2020. Retrieved from: https://www.belstat.gov.by/upload/iblock/256/2560ea86212a257ee3c18811480ee743.p df (downloaded 24. 02. 2021).

NATIONAL STATISTICAL COMMITTEE OF THE REPUBLIC OF BELARUS. 2020: Labor and Employment in The Republic of Belarus. Statistical Book. Minsk. p. 316. Retrieved from: https://www.belstat.gov.by/upload/iblock/c17/c1758aafc21ec069dafba92b27dea768.pdf (downloaded 24. 02. 2021).

SAMOKHINA, E. A. 2011: Business Education In Russia: Factors Of Development // Actual Problems Of Society: Economics, Law, Sociology And Philosophy: Collection Of Scientific Articles On The Results Of The International Conference, Volgograd, 29-30 Sep. 2011 : In 2 ch. Ch. Ya / Ed. By I. E. Belskikh, V. N. Gulyaikhin. Volgograd. Scientific Publishing House, pp. 221-222. (downloaded 24.02.2021).

STATISTICAL COMMITTEE OF THE REPUBLIC OF ARMENIA (ARMSTAT). 2020: Labor Market in Armenia. 2018-2019: Statistical Handbook. Yerevan. Retrieved from: https://armstat.am/file/doc/99510748.pdf (downloaded 24. 02. 2021). 
Corvinus University of Budapest

Doctoral School of International

Relations and Political Science

ISBN 978-963-503-886-2 